\title{
APROPRIAÇÕES ARQUITETÔNICAS O NEOCOLONIAL NA DIOCESE DE LIMEIRA
}

RENAN ALEX TREFT

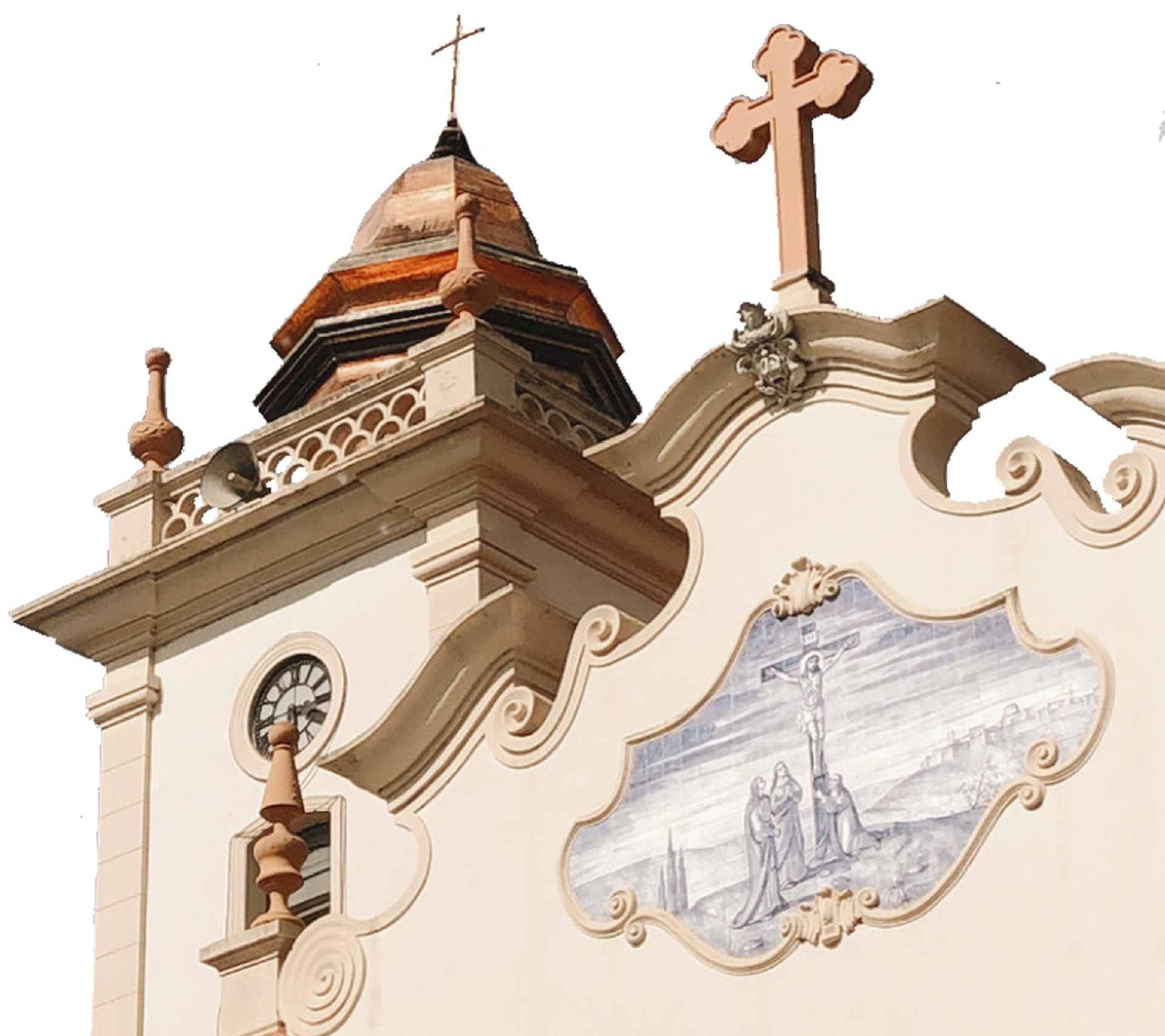





\section{$\frac{\text { APROPRIAÇÕES ARQUITETÔNICAS }}{\text { O NEOCOLONIAL NA DIOCESE DE LIMEIRA }}$}

RENAN ALEX TREFT 

FAUUSP

\author{
APROPRIAÇÕES ARQUITETÔNICAS \\ O NEOCOLONIAL NA DIOCESE DE LIMEIRA
}

ARCHITECTURAL APPROPRIATION

THE NEOCOLONIAL IN LIMEIRA'S DIOCESE

RENAN ALEX TREFT

Dissertação para obtenção do título de Mestre em Arquitetura e Urbanismo apresentada ao Programa de Pós-Graduação em Arquitetura e Urbanismo da Faculdade de Arquitetura e Urbanismo da Universidade de São Paulo.

Área de concentração: História e Fundamentos da Arquitetura e do Urbanismo

Orientadora: Profa. Dra. Maria Lucia Bressan Pinheiro

SÃO PAULO 


\begin{abstract}
AUTORIZO A REPRODUÇÃO E DIVULGAÇÃO TOTAL OU PARCIAL DESTE TRABALHO, POR QUALQUER MEIO CONVENCIONAL OU ELETRÔNICO, PARA FINS DE ESTUDO E PESQUISA, DESDE QUE CITADA A FONTE.
\end{abstract}

EXEMPLAR REVISADO E ALTERADO EM RELAÇÃO À VERSÃO ORIGINAL, SOB RESPONSABILIDADE DO AUTOR E ANUÊNCIA DA ORIENTADORA.

A VERSÃO ORIGINAL, EM FORMATO DIGITAL, FICARÁ ARQUIVADA NA BIBLIOTECA DA FACULDADE.

SÃO PAULO, 12 DE MARÇO DE 2021.

renan.treft@yahoo.com.br

Catalogação na Publicação

Serviço Técnico de Biblioteca

Faculdade de Arquitetura e Urbanismo da Universidade de São Paulo

Treft, Renan Alex

Apropriações arquitetônicas: o Neocolonial na Diocese de Limeira / Renan Alex Treft; orientadora Maria Lucia Bressan Pinheiro. - São Paulo, 2021. p. 210 .

Dissertação (Mestrado) - Faculdade de Arquitetura e Urbanismo da Universidade de São Paulo. Área de concentração: História e Fundamentos da Arquitetura e do Urbanismo.

1. Neocolonial. 2. Arquiterura Religiosa. 3. Cidade Paulistas. 4. Preservação. I. Pinheiro, Maria Lucia Bressan, orient. II. Título.

Elaborada eletronicamente através do formulário disponível em: $<$ http://www.fau.usp.br/fichacatalografica/ $>$ 
A Maria, minha mãe, que mesmo não estando presente, me deu forças para continuar, e a Sebastião, meu pai, por todo o apoio, incentivo e presença paterna. 



\section{AGRADECIMENTOS}

Com a finalização dos trabalhos do mestrado com essa dissertação é impossível não lembrar de todo o percurso trilhado e sentir gratidão pela experiência vivida. Por isso, quero prestar um preito de gratidão:

A querida Prof. Maria Lúcia; pela amizade, orientação e condução dos trabalhos desenvolvidos. Sua experiência e conhecimento foram basilares para o andamento desta pesquisa, sem os quais não teria conseguido. Além disso, agradeço pela paciência e dedicação em minhas orientações, que me motivaram sempre a "ir além".

A meu pai, Sebastião; que além de ser um incentivador constante dos estudos, se mostrou um excelente parceiro de viagens e visitas aos acervos. Dividir com ele esses momentos e todas as descobertas feitas tornaram esta pesquisa muito mais prazerosa.

Aos meus irmãos: Caio e Thais; pela amizade e companheirismo.

Aos professores: Fernando Atique e Ana Paula Farah; por terem aceito o convite para comporem a banca final e pelas preciosas considerações no exame de qualificação.

Aos amigos, arquitetos e professores; Ana Paula Pedro, Denise Geribello, Ivone Salgado, Marcelo Cachioni, Mateus Rosada e Renata Baesso pelo incentivo, dicas e conversas arquitetônicas.

A Dom José Roberto Fortes Palau, Bispo de Limeira; pela disponibilidade e permitir o andamento desta pesquisa, e aos padres das paróquias estudadas e funcionários da Diocese de Limeira pela cordialidade e colaboração no levantamento das informações e nas pesquisas nos acervos correspondentes. Agradeço também às funcionárias da Cúria de Campinas e do arquivo da Cúria de São Paulo pela atenção.

Aos professores da FAU USP; Ana Castro, Beatriz Kühl, Fábio Mariz, Joana Mello, Mônica Junqueira e Reginaldo Ronconi, por todo conhecimento transmitido nas disciplinas cursadas e, Antônio Barossi, Cláudia Andrade, Fernanda Fernandes e Roberta Kronka pela confiança em mim depositada nos estágios PAE realizados.

Aos amigos do programa de pós-graduação; Beatriz Fernandez, Benjamin Saviani, Eduardo Ribeiro, Fabiane Savino, Laís Amorim e Renata Campiotto pelas conversas e pesquisas compartilhadas, e aos amigos de sempre; pelo apoio e momentos vividos.

Ao Rodolfo; por todos esses anos e companheirismo.

À CAPES; pelo financiamento desta pesquisa. 



\section{RESUMO}

O presente trabalho trata da construção de igrejas matrizes em estilo Neocolonial na Diocese de Limeira (divisão territorial eclesiástica criada em 1976), afim de avaliar a repercussão do movimento arquitetônico lançado por Ricardo Severo no início do século XX em alguns edifícios de caráter religioso no interior do estado de São Paulo. O recorte territorial abrange 5 cidades e suas respectivas paróquias, a saber: Catedral Nossa Senhora das Dores, em Limeira; Paróquia Nossa Senhora da Conceição, em Santa Cruz da Conceição; Santuário São Sebastião, em Porto Ferreira; Paróquia Jesus Crucificado, em Iracemápolis; e Paróquia Santa Gertrudes, em Cosmópolis. O trabalho visa ainda evidenciar aspectos referentes à formação das cidades mencionadas e sua relação com a igreja matriz, afim de compreender o processo formativo territorial e as questões incidentes de cada período e região, que resultaram em percursos históricos permeados por múltiplas nuances, que incidiram diretamente no edifício da igreja matriz, objeto de reformas e reconstruções ao longo das décadas, que foram reconstruídos em neocolonial na metade do século XX. O estudo dos edifícios religiosos neocoloniais permite entender qual foi a aceitação deste conceito de modernidade e o rompimento com a historicidade clássica pela Igreja Católica, no decorrer do século XX, durante a construção (ou reconstrução) dos seus novos templos. Busca ainda estabelecer parâmetros para análise dessa produção, que fora realizada em larga escala neste território, ainda pouco estudada e documentada, afim de inserir esses edifícios no debate preservacionista.

Palavras-chave: neocolonial, arquitetura religiosa, cidades paulistas, preservação.

TREFT, Renan Alex. Apropriações arquitetônicas: o Neocolonial na Diocese de Limeira. Dissertação de Mestrado. Faculdade de Arquitetura e Urbanismo - Universidade de São Paulo. São Paulo, 2021. 



\section{ABSTRACT}

The following article discusses the construction of main churches in neocolonial style in Limeira's diocese (ecclesiastical land division creates in 1976), in order to evaluate the repercussion of the architectonical movement launched by Ricardo Severo in the beginning of the twentieth century in some religious buildings of São Paulo's countryside. The territorial dimension contains 5 cities and its main churches: Nossa Senhora das Dores Cathedral, located in Limeira; Nossa Senhora da Conceição Church, located in Santa Cruz da Conceição; São Sebastião Sanctuary, located in Porto Ferreira; Jesus Crucificado Church, located in Iracemápolis; and, last but not least, Santa Gertrudes Church, located in Cosmópolis. This article also aims to emphasize the aspects of the formation of the cities mentioned before and the relation between them and the main churches, in order to understand the process of territorial formation and the main points of each period and region, that resulted in historical aspects with multiple nuances. In addition to this, those multiple nuances reflected directly in the main churches, which were refurbished and reconstructed along the decades and were also rebuilt in neocolonial style in the middle of the twentieth century. The study of neocolonial religious buildings allows us to understand the acceptance of this concept of modernity and the rupture with the classical pattern of the Catholic Church, during the construction (or reconstruction) of new temples along the twentieth century. This paper also intends to stablish parameters to the analysis of this production, which was done in large volume in this territory. Finally, the purpose of this article is to introduce those buildings in the preservationist debate, once they are still little studied and documented.

Keywords: neocolonial, religious architecture, cities of São Paulo, preservation.

TREFT, Renan Alex. Architectural appropriation: the Neocolonial in Limeira's Diocese. Master's dissertation. Faculdade de Arquitetura e Urbanismo - Universidade de São Paulo. São Paulo, 2021. 



\section{SUMÁRIO}

18 INTRODUÇÃO

26 CAPÍTULO 1: UM CHÃO CATÓLICO

A FORMAÇÃO TERRITORIAL DA DIOCESE DE LIMEIRA

271.1 - A FORMAÇÃO DE VILAS E CIDADES NO BRASIL

341.2 - CAMINHOS, IGREJAS, FREGUESIAS: SURGEM AS CIDADES

78 CAPÍTULO 2: CATOLICISMO E A ARQUITETURA

A PRESENÇA DA IGREJA E SEUS EDIFÍCIOS

802.1 - O PROTAGONISMO DA IGREJA NA SOCIEDADE

862.2 - AS IGREJAS CRESCEM E AS PARÓQUIAS SE ESTABELECEM

116 CAPÍTULO 3: UM DESEJO DE MODERNIDADE: REFORMAS E RECONSTRUÇOES O NEOCOLONIAL CHEGA À FUTURA DIOCESE DE LIMEIRA

119 3.1-O MOVIMENTO NEOCOLONIAL

127 3.2- UMA NOVA IGREJA PARA UMA NOVA CIDADE

172 3.3- OUTRAS IGREJAS NEOCOLONIAIS EXISTENTES NA DIOCESE DE LIMEIRA

178 CONSIDERAÇÕES FINAIS

190 REFERÊNCIAS

202 ANEXOS

204 DADOS BIOGRÁFICOS DOS PROFISSIONAIS 

NTRODUÇÃO 


\section{INTRODUÇÃO}

"Em todo o momento de atividade mental acontece em nós um duplo fenômeno de percepção: ao mesmo tempo que temos consciência dum estado de alma, temos diante de nós, impressionando-nos os sentidos que estão virados para o exterior, uma paisagem qualquer, entendendo por paisagem, para conveniência de frases, tudo o que forma o mundo exterior num determinado momento da nossa percepção".

Fernando Pessoa

Todo cidadão brasileiro, independentemente da sua religião, reconhece a presença da Igreja Católica e a força de seu simbolismo e suas tradições na vivência cotidiana das cidades. De uma maneira geral, as igrejas ocupam posição de destaque e relevância na paisagem urbana, configurando-se como elementos identitários importantes em suas respectivas cidades. A igreja matriz de toda cidade é um ponto de referência urbana, palco de importantes eventos civis e sociais e lugar de encontro da comunidade católica, ainda hoje a maior do país.

Este estudo, cujo intuito é apresentar as igrejas neocoloniais existentes na Diocese de Limeira, é resultado de um longo percurso, onde questões pessoais e o conhecimento de novos assuntos se entrelaçaram. O interesse pela arquitetura neocolonial veio por consequência de estudos de graduação, motivados a partir dos meus interesses pessoais, dentro da minha formação. Nesse sentido, o primeiro contato com a arquitetura neocolonial se deu nas pesquisas de iniciação cientifica ${ }^{1}$ referentes à cidade de Limeira e suas igrejas.

A partir das investigações acerca da Catedral Nossa Senhora das Dores de Limeira, e da constatação de que seu edifício havia tido um percurso histórico-arquitetônico movimentado, cuja última versão se trata de um edifício neocolonial da metade do século XX, novas questões foram sendo descobertas e instigando novas abordagens. A principal observação que motivou este estudo foi a de que outras cidades que compõem a Diocese de Limeira tinham passado por processos semelhantes, em período concomitante e com resultados parecidos. Assim, foi

1 As pesquisas intituladas "Configuração espacial de Limeira: Capela (1826), Freguesia (1832) e Vila (1884) " e "Formação urbana de Limeira no entorno da Igreja Matriz Nossa Senhora das Dores de Limeira e da Capela Nossa Senhora da Boa Morte e Assumpção" foram desenvolvidas de 2015 a 2017 na Faculdade de Arquitetura e Urbanismo sob a orientação da Profa. Dra. Ivone Salgado junto ao Programa de Pós-Graduação (POSURB) da PUC Campinas e dão início a investigação sobre a arquitetura nas cidades do interior paulista, especificadamente na região de Limeira. Neste trabalho há trechos provenientes dos resultados destas pesquisas que foram publicados no capítulo: TREFT, Renan Alex; SALGADO, Ivone. Construção da Igreja Matriz Nossa Senhora das Dores e da Capela Nossa Senhora da Boa Morte de Limeira. In: Norma Regina Truppel Constantino; Renata Cardoso Magagnin; Sandra Medina Benini. (Org.). Cidade, História e Patrimônio. 1ed.TUPA: ANAP, 2019, v. único, p. 143-162. 
estabelecido o objeto deste trabalho: a reconstrução, na década de 1950, das igrejas matrizes de 5 cidades da supracitada diocese, nas quais foi empregado o Neocolonial, a saber: Catedral Nossa Senhora das Dores, em Limeira; Paróquia Nossa Senhora da Conceição, em Santa Cruz da Conceição; Santuário São Sebastião, em Porto Ferreira; Paróquia Jesus Crucificado, em Iracemápolis; e Paróquia Santa Gertrudes, em Cosmópolis. Com isso, a pesquisa visa preencher lacunas da historiografia e compreender melhor a difusão deste movimento pelo estado de São Paulo, inclusive quanto ao eventual protagonismo dos arquitetos responsáveis por esta difusão. O fato de uma mesma região do estado de São Paulo concentrar um conjunto de edifícios de mesmo programa, projetados e construídos no mesmo período, seguindo características arquitetônicas afins, afigurou-se propício para investigar a difusão

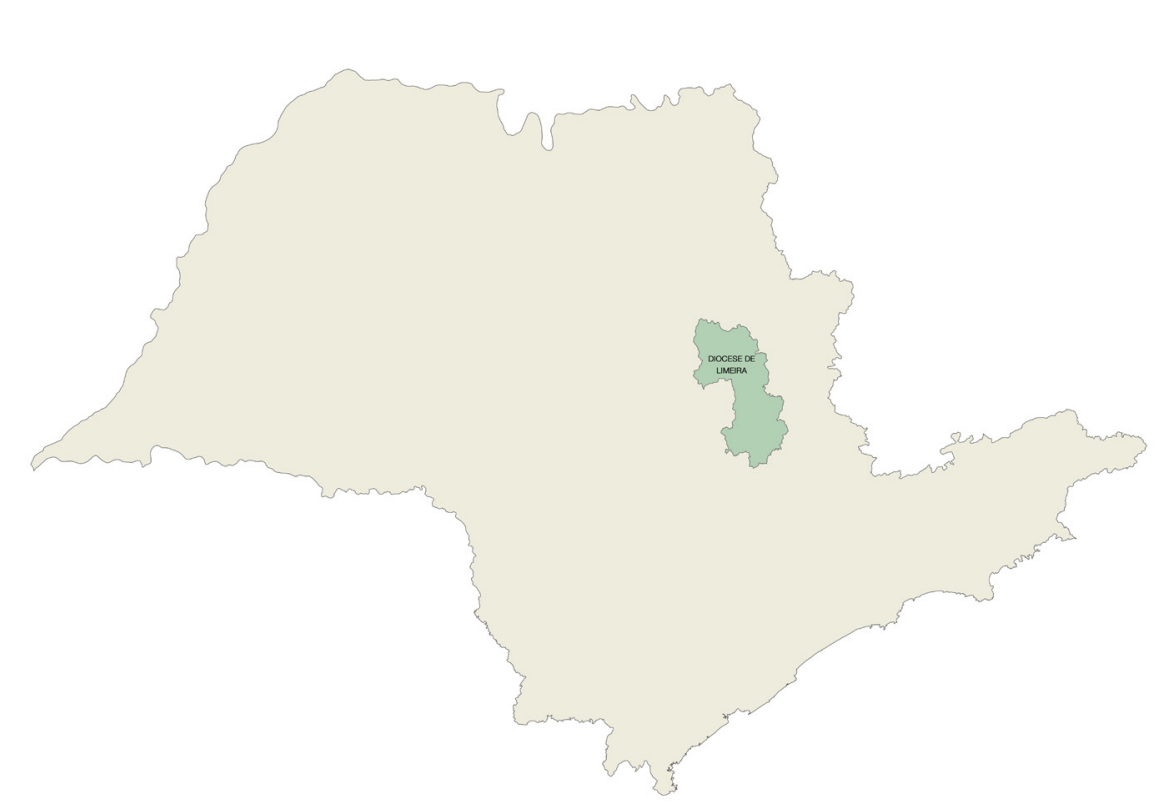

Figura 01: Território da Diocese de Limeira dentro do estado de São Paulo. Fonte: Elaborado pelo autor. da arquitetura neocolonial em São Paulo, dando continuidade a trabalhos a c a d êm i cos recentes.

No que se refere ao recorte territorial, é importante pontuar que diocese é uma divisão territorial estabelecida pela Igreja Católica que configura um conjunto de cidades governadas por um episcopado. No caso da Diocese de Limeira, sua criação se deu em 1976 pelo Papa Paulo VI, através do documento papal "Bula de Superna". É constituída por 16 municípios, a saber: Americana, Analândia, Araras, Artur Nogueira, Cordeirópolis, Cosmópolis, Conchal, Engenheiro Coelho, Descalvado, Limeira, Leme, Iracemápolis, Nova Odessa, Pirassununga, Porto Ferreira e Santa Cruz da Conceição, que foram desmembrados tanto da Arquidiocese de Campinas, como da Diocese de Piracicaba, a depender de sua localização.

O recorte territorial escolhido pode parecer anacrônico, uma vez que a constituição da diocese se deu após a reconstrução das igrejas matrizes. Porém, esta divisão territorial favoreceu a delimitação do espaço de análise, dadas as semelhanças compartilhadas entre as cidades que a constituem, que vão além do objeto central deste estudo. 


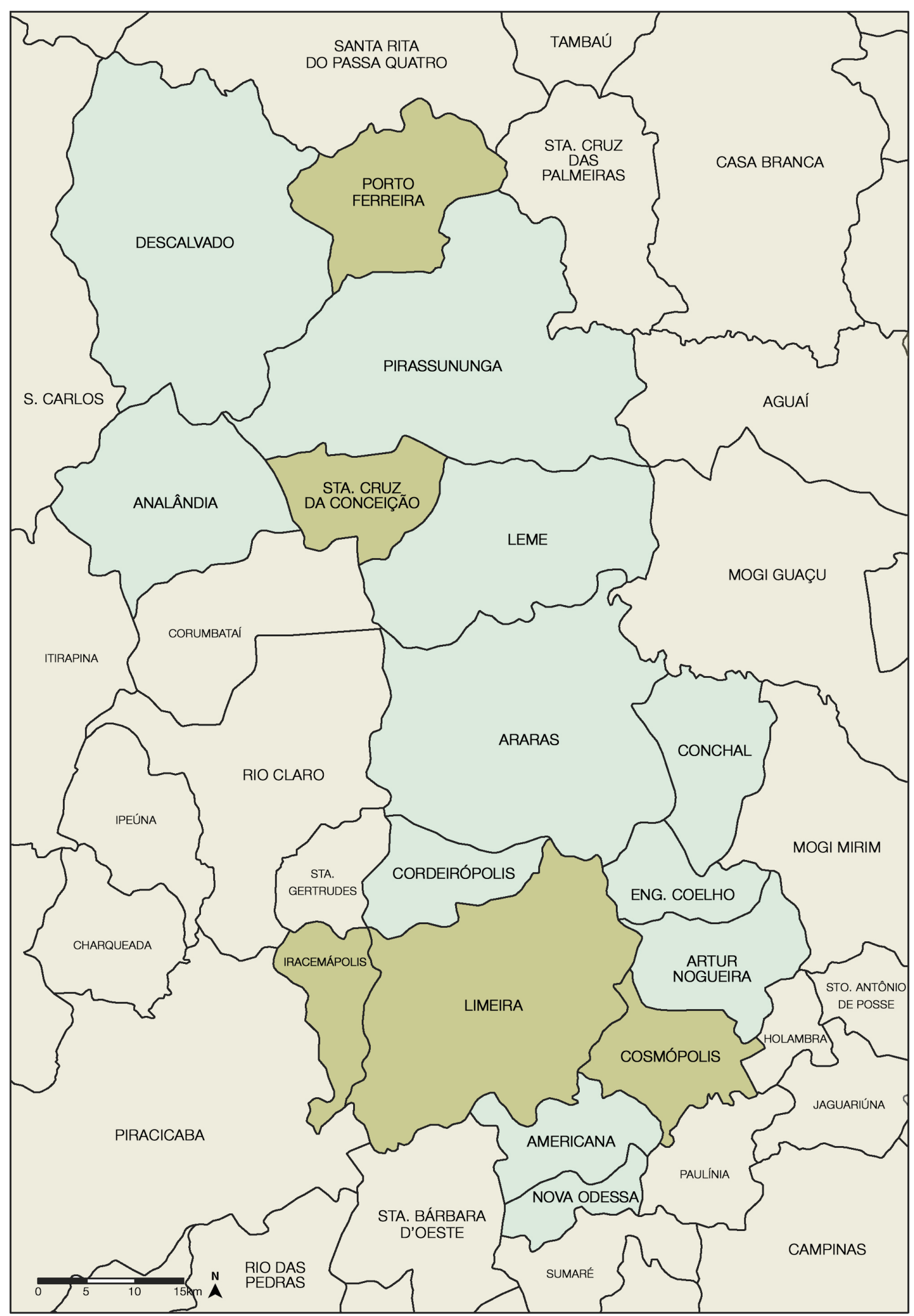

Figura 02: Mapa da Diocese de Limeira (em verde). Destaca-se (em marrom) as 5 cidades que possuem igrejas matrizes neocoloniais apresentadas neste estudo. Fonte: Elaborado pelo autor. 
O território da atual Diocese de Limeira é constituído historicamente por microrregiões que propiciaram o desenvolvimento urbano em períodos diferentes ao longo da história, pautados em atividades econômicas e sociais endógenas à região. A região da sesmaria do Morro Azul, na parte sul da Diocese, próxima ao rio Piracicaba, configura-se como a primeira ocupação oficial do território. Ao longo dos anos, as terras ao norte foram sendo desbravadas e ocupadas, até o encontro com o rio Mogi Guaçu, onde formaram-se outros sítios urbanos a partir de outras lógicas de ocupação e desenvolvimento. Por fim, a porção territorial mais ao leste são as cidades mais recentes, com processos formativos divergentes das primeiras cidades, colaborando desta forma para entender as diversas maneiras de se ocupar o território e as variadas relações estabelecidas com a Igreja e seus templos.

Desta forma, no desenvolvimento do trabalho ficou clara a necessidade da investigação dos processos e percursos históricos, permeados por múltiplas nuances, de cada uma dessas cidades, e sua intrínseca ligação com a Igreja Católica - processos estes que explicam não apenas a reconstrução dessas igrejas matrizes, como a própria constituição da Diocese de Limeira, no último quartel do século XX.

Portanto, o primeiro caminho identificado para entender os fatos que explicam a contínua renovação construtiva das igrejas por esse território, foi compreender a relação estabelecida entre o governo de cada época e a Igreja, desde do período de formação destas cidades. De maneira geral, os edifícios religiosos estão intrinsecamente associados com a cidade em que estão implantados, sendo que, muitas vezes sua construção confunde-se com a própria fundação da cidade, seguindo as diretrizes estabelecidas pelo sistema do padroado. Estabelecia-se assim uma relação simbiótica na qual era impossível dissociar a Coroa da Igreja, cujos efeitos reverberaram na consolidação das paróquias e nas constantes alterações realizadas nas igrejas matrizes ao longo dos anos.

Analisar historicamente a relação destes edifícios com a urbe onde se encontram, bem como as relações políticas estabelecidas, foi necessário para compreender os movimentos realizados pela Igreja na primeira metade do século XX, num processo de reestruturação de sua própria instituição após a proclamação da República e consequente separação do Estado.

Com a chegada do século XX e com as mudanças significativas vivenciadas no campo político, social e econômico, a Igreja passou a se comportar de maneira diferente na sociedade, buscando se consolidar na nova forma de governo. Neste processo de renovação buscado pela Igreja, as igrejas matrizes serão objeto de reformas e reconstruções, para se adequarem ao modelo de modernidade desejado para a época.

No campo da arquitetura, a efervescência de novos modelos e formas de se construir fez surgir novas abordagens e estilos arquitetônicos, dentre eles o Neocolonial. No que se refere 
a este, as pesquisas e buscas sobre o assunto realizadas até agora apontam que o interior paulista foi território fértil para a produção desta arquitetura. E que, como aponta Luciana Mascaro (2008) em sua tese de doutorado, nessa região, houve uma difusão da arquitetura neocolonial, "maior do que era suposto e com grande número de nuances" (MASCARO, 2008, p.130), uma vez que o escasso número de pesquisas realizadas a esse respeito indicava casos esporádicos dessa arquitetura fora da capital paulista (D'ALAMBERT, 2004, p.194). Indícios estes, que corroboram a relevância das questões abordadas por este trabalho.

Para entender como se deram as relações dos templos religiosos com a sociedade, com o sitio onde estavam implantados e como se davam as alterações neles realizadas, foi necessário realizar uma vasta investigação na documentação primária proveniente das paróquias e das cúrias diocesanas. Deste modo, além de se trabalhar com a literatura científica, essencial para traçar paralelos com uma realidade mais geral, foi realizada uma busca intensiva nos arquivos e acervos da Igreja. O principal material consultado foram os livros tombos, cadernos que são utilizados para o registro da vida e da dinâmica paroquial pelo pároco, que trazem informações relevantes sobre os mais variados assuntos. Tais narrativas, apesar de pautadas por múltiplos interesses ideológicos e pragmáticos, foram essenciais para a compreensão de aspectos relevantes da atuação da Igreja e seu papel na formação do território, e, sobretudo, da produção de igrejas neocoloniais e as questões que as permeiam.

Por outro lado, ao estudar o enraizamento desses edifícios em suas respectivas cidades e sua importância na história local, o estudo contribui para problematizar as práticas preservacionistas locais, que não tem contemplado tais edifícios como merecedores de preservação.

Por se tratar de 5 cidades distintas que compartilham um único ponto em comum, com períodos e percursos históricos diversos, a organização do trabalho se tornou um tanto quanto complexa. Não era possível estabelecer um tópico para cada paróquia, pois se tornaria difícil apontar os distanciamentos e as aproximações existentes entre elas. Realizar uma divisão cronológica do todo (cidades e paróquias) comprometeria o entendimento do leitor, dada a diversidades de informações e a abrangência do período, que se estende de 1820 até 1960, durante o qual diversos fatos ora se sobrepõem, ora tem lugar sob condições totalmente distintas das anteriores. Como forma de padronização e organização do trabalho, as cidades são apresentadas em ordem cronológica apenas no capítulo I, a partir da data das primeiras manifestações que fomentaram sua formação, a saber: Limeira, Santa Cruz da Conceição, Porto Ferreira, Iracemápolis e Cosmópolis. Os demais capítulos, que tratam das respectivas paróquias de cada cidade, seguem a mesma ordem do capítulo 01, visando um melhor entendimento do leitor a partir da lógica já apresentada. Portanto, as paróquias serão apresentadas nos capítulos 02 e 03 na seguinte ordem: Catedral Nossa Senhora das Dores (Limeira), Paróquia Nossa Senhora da Conceição (Santa Cruz da Conceição), Santuário 
São Sebastião (Porto Ferreira), Paróquia Jesus Crucificado (Iracemápolis) e Paróquia Santa Gertrudes (Cosmópolis).

Assim, para uma melhor compreensão das questões relevantes em cada cidade, culminando no ponto central deste estudo, o trabalho foi dividido em 3 grandes blocos:

No capítulo 01, a primeira parte trata da atuação constante da Igreja no território, como formadora das cidades brasileiras e como agente modelador da sociedade, mesmo após a separação do Estado ocorrida com proclamação da República. O texto evidencia aspectos da gênese e do desenvolvimento dos núcleos urbanos no Brasil, desde a colônia até a República, além de abordar as marcas deixadas pela Igreja nas cidades brasileiras, especialmente nas que viriam a formar a Diocese de Limeira, no século XX. Na segunda parte, traçamos um panorama do percurso histórico-cronológico da constituição das 5 cidades que detém as igrejas estudadas, para evidenciar a relação longínqua, e por vezes conflituosa, estabelecida entre o núcleo urbano e sua igreja matriz. Além disso, o texto busca mostrar como se deu a formação das demais cidades da diocese, e os fatores determinantes na expansão e na consolidação dos núcleos urbanos.

O capítulo 02 trata da atuação da Igreja na vida da sociedade, principalmente após a proclamação da República, a expansão do número de católicos e a consolidação da instituição no novo regime governamental. O texto traz uma recuperação histórica de informações relevantes sobre os problemas enfrentados pelos padres, questões de ordem social das paróquias, da 'fábrica' e do patrimônio, além de evidenciar a trajetória percorrida pelas igrejas matrizes ao longo dos anos e as alterações realizadas em seus edifícios.

No capítulo 03, tratamos do assunto que é o cerne deste trabalho, o Neocolonial. Na primeira parte, apontamos os aspectos históricos do próprio movimento que deram origem ao estilo em questão, e qual foi sua aceitação no ambiente religioso. Na segunda parte, debruçamonos em mostrar os detalhes do processo vivenciado por cada paróquia na reconstrução de suas igrejas; quais foram os agentes, os arquitetos atuantes e a reverberação de tais obras nas sociedades locais. No final do capítulo são apresentadas outras igrejas neocoloniais existentes no território da referida Diocese, mas que não fizeram parte deste estudo, por não se tratar de igrejas matrizes reconstruídas.

Procuramos deste modo, através do estudo das cidades e de suas igrejas matrizes, evidenciar aspectos da presença da Igreja Católica nas cidades brasileiras, que culminaram em construções e reformulações edilícias importantes para a compreensão da produção arquitetônica paulista, principalmente com a utilização de um estilo arquitetônico específico para a reconstrução de suas igrejas matrizes em meados do século XX. 

CAPÍTULO OI 


\section{CAPITULO OI}

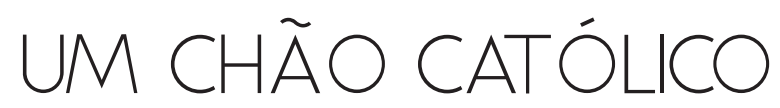

A FORMAÇÃO TERRITORIAL DA DIOCESE DE LIMEIRA

As cidades brasileiras possuem uma intrínseca relação com a Igreja Católica. Em qualquer visita ou passeio, é normal encontrar em boa parte delas uma praça central e uma suntuosa Igreja Matriz, que, quando perguntado, qualquer morador afirma conhecer desde que nasceu, e saber que está lá desde a fundação da cidade, ou senão, a existência de um antigo edifício, demolido para dar lugar a um novo.

Quanto mais velha a cidade, mais profunda e antiga é sua relação com sua igreja matriz, que geralmente exerceu um papel central na sua gênese e em seu desenvolvimento. A presença da Igreja neste território gerou marcas definitivas na história das cidades e na vida das pessoas, uma vez que, a Igreja centralizava serviços religiosos e administrativos, além de promover atividades e eventos que movimentavam a região e traziam entretenimento para o local, na pacata vida do dia a dia experimentada nas vilas e cidades no século XIX. Na região estudada, os eventos religiosos eram praticamente os únicos que aconteciam e integravam diversos acontecimentos que movimentavam a população.

Deste modo, a igreja ocupava um papel central na vida dos moradores, pois suas celebrações e preceitos determinavam dias de descanso e feriados, regulando desta forma a vida da cidade. A ida à igreja era a única atividade social permitida para mulheres e crianças durante boa parte do século XIX, além de ser atividade oficial aos domingos e dias santos, quando missas festivas, procissões, liturgias e sermões animavam a cidade. As festividades religiosas que aconteciam no decorrer do ano eram esperadas e aguardadas pela população, que se preparava com novenas e intensas atividades religiosas.

No que se refere à igreja matriz, campanhas para reformas e construções eram costumeiramente empreendidas em favor do edifício símbolo da cidade, cuja arquitetura representava o poderio e a pujança da sociedade local. Tais obras eram estimuladas pelos párocos junto à população, que aderia à causa e lutava para sua consolidação. As finalizações de tais campanhas contavam com solenes celebrações e a presença do Bispo Diocesano, cuja 
vinda era uma atração muito esperada. Desta forma, a Igreja foi marcando a sociedade e a história local, através de suas ações e de seus dogmas, e promovendo, desta forma, relações de identidade, pertencimento e tradições vinculadas a cada localidade.

Desta intrínseca relação, é interessante pautar que a Igreja atuava como um órgão de caráter político, ao menos no período Colonial e Imperial, devido ao vínculo entre a Coroa e o altar, visando os interesses de ambas as partes, numa relação mútua de troca de favores. Tal relação gerou um padrão de gênese para as cidades brasileiras, no qual a Igreja Católica está inserida de modo direto e definitivo, através do processo detalhado a seguir.

\section{1 - A FORMAÇÃO DE VILAS E CIDADES NO BRASIL}

A Igreja sempre buscou manter-se próxima e vinculada por laços estreitos com os poderes temporais, pois uma relação diplomática era a garantia da autorização para a presença do clero e até mesmo de subsídios pecuniários para a construção e a manutenção dos templos, necessários para a vivência cristã. A relação estabelecida entre o poder monárquico e o poder eclesiástico interessava às duas partes: a Igreja garantia assim sua permanência no local e sua instalação em novas terras conquistadas, e a coroa beneficiava-se da influência e do poder conferido pela religião como instrumento de ordem pública. A simbiose de poderes era dada a partir de tratados e acordos assinados entre o Sumo Pontífice, o Papa, e o Rei regente. No caso de Portugal, foi instituído o sistema do Padroado ${ }^{1}$, instrumento político que garantia direitos e deveres entre as partes: a Igreja Católica se beneficiava em ser a religião oficial do reino e usufruir de benefícios específicos, como ter seus templos construídos e mantidos pela coroa, além do pagamento de côngruas e salários aos padres e bispos. Em contrapartida, a Coroa era responsável por indicar os nomes de padres e bispos aos cargos eclesiásticos, cabendo ao Papa apenas a função de aceitar ou não a nomeação, além de receber colaboração da Igreja no fortalecimento do projeto colonial (SOUZA, 2004, p.25).

Essa relação gerou uma mistura difícil de ser dissociada, pois a Igreja desempenhava um papel político dentro da coroa, sendo responsável também pela formação e fundação das cidades brasileiras, através do estabelecimento de seus templos e da constituição de suas freguesias².

1 O Padroado é um importante acordo político firmado entre a Santa Sé e a Coroa Portuguesa, cujas prerrogativas irão resultar numa relação bastante complexa entre as partes, além das questões referentes ao processo de concessão de terras e a construção de capelas. Para mais informações ver: HOORNAERT (1974), SOUSA (2004), MARX (1991) e ROSADA (2010).

2 Freguesia foi o termo utilizado até o fim do período Imperial para designar um território eclesiástico atendido por um pároco, e a sede dos serviços civis e religiosos por ela realizados, o que hoje se aproxima das paróquias. As freguesias detinham, além dos serviços religiosos, o dever de desempenhar serviços civis, como registros em geral, serviços que hoje são conferidos aos cartórios. Cabia-lhe também organizar o território, através de loteamentos e formação das quadras. Em geral, o nome dado às freguesias seguia uma ordem: primeiro o nome do santo padroeiro das terras onde estava construída a igreja, seguido da característica 
De maneira geral, a Igreja Católica foi, até o período da República, elemento estruturador das cidades brasileiras, capaz de determinar boa parte de sua configuração espacial. Sendo a coroa portuguesa católica, toda a colônia herdaria estes costumes e os empregaria neste território, principalmente no trato da terra e na política. Além disso, a Igreja desempenhava um papel essencial na vida dos colonos, pois era responsável não apenas por ministrar os sacramentos, como pelos registros em geral, como nascimento, casamentos e óbitos e pelos espaços de sepultamento junto às igrejas e, posteriormente, pelos cemitérios. Deste modo, a Igreja foi se consolidando como parte do Estado no território brasileiro, sendo responsável por todo tipo de infraestrutura necessária para a promoção da vida, como hospitais, asilos, orfanatos e cemitérios (ROSADA, 2010, p.38).

No processo de constituição de cidades no Brasil colonial, observa-se uma constância durante séculos e uma mesma sistemática difusa em todo o território da então colônia portuguesa. As instâncias de poder organizavam-se hierarquicamente, onde as vilas tinham papel inferior às cidades, mas superior às capelas e freguesias; seguindo padrões portugueses, as instâncias administrativas, jurídicas e eclesiásticas sobrepunham seus territórios no espaço (BUENO, 2009, p.252).

Como toda a terra brasileira pertencia à coroa portuguesa e era muito extensa, com o intuito de evitar invasões de nações inimigas, e apropriar-se da terra de fato e dela explorar os recursos naturais, eram as cedidas sesmarias, ou seja, pedaços de terras a pessoas com forte influência política e econômica, geralmente com algum título de nobreza, para que se estabelecessem naquela região e a povoassem. Na maioria das vezes, estas terras estendiamse sertão adentro, com o intuito de ocupar o interior do país.

Com a concessão das sesmarias, os receptores de terra, os sesmeiros, passaram a ocupar os territórios a eles designados, estabelecendo morada e cultivando a terra. Muitas dessas sesmarias foram o início dos grandes engenhos produtores de açúcar, ou estiveram associadas à produção de grãos e demais mantimentos para a própria sobrevivência. As pessoas que residiam neste solo, sem pertencer à família do sesmeiro, moravam de favor e geralmente formavam algum vilarejo em um ponto de topografia estratégica, como por exemplo; a presença de um curso d'agua ou estrada que levava a alguma localidade de maior porte. Características estas, presentes em quase toda configuração espacial das cidades brasileiras.

De maneira geral, o surgimento de uma aglomeração urbana no Brasil Colonial era marcado pela formação do patrimônio religioso em invocação a um santo de devoção, o padroeiro do local. Segundo Murillo Marx (1991), o patrimônio religioso surgiu no Brasil de maneira

geográfica ou de algum nome pelo qual já se conhecia a região. 
tímida e discreta e se perpetuou como sistemática para a formação das cidades por muito tempo. Era constituído por uma gleba de terra, doada pelo sesmeiro à Igreja, que permitia a construção da capela e também da área adjacente, conforme recomendado pelas "Constituições Primeiras do Arcebispado da Bahia", para a formação do casario que abrigaria os primeiros habitantes dando origem ao futuro núcleo urbano. De uma parte, ocupavase um determinado terreno e implantava-se o templo desejado; de outra, propiciava-se a aglomeração de moradias e negócios (MARX, 1991, p.41).

Doar as terras para uma ermida ou capela muitas vezes afastava do fazendeiro possíveis problemas com a lgreja. [...] Junto ao processo constava uma declaração de fé. Aceita a doação do patrimônio religioso, a escritura podia ser feita em nome do próprio santo [...] Não podendo ser fundadas em lugares ermos e despovoados, as capelas, além do sentido de posse da terra, tinham também a função de consolidar a povoação formada perto das fazendas (TIRAPELLI, 2005, p.18).

Feita a doação do patrimônio religioso, era realizado o traçado regulador, que em geral era determinado por condicionantes topográficas, tendo sempre a igreja e seu adro ao centro. Não se levavam em conta as características e as qualidades arquitetônicas da edificação religiosa, inclusive se estava concluída ou não; o importante era seu papel simbólico, que justificava a ocupação da terra (TIRAPELLI, 2005, p.20). Com a doação do patrimônio religioso para a constituição da capela, a Igreja passaria a ter o domínio sobre aquele território, passando a aforar os lotes, ou seja, parcelar a área mediante a cobrança de uma espécie de imposto anual dos moradores, conforme nos aponta Maria Derntl (2010):

A capela deveria ter um patrimônio fundiário próprio e um dote ou patrimônio capaz de assegurar uma renda anual mínima para sua manutenção. Antes de começar a funcionar, deveria ser inspecionada e consagrada para o culto (DERNTL, 2010, p.66).

A inspeção era realizada por uma autoridade diocesana, e dada a aprovação das condições de culto, o edifício era então anexado a alguma freguesia próxima, para que a capela fosse provisionada e habilitada para as celebrações dos sacramentos ${ }^{3}$. Caso o local tivesse um contingente populacional suficiente para as atividades religiosas com regularidade, e o recolhimento do aforamento fosse suficiente para sua manutenção e sustento do padre, a capela poderia ser elevada ao status de capela curada 4 . As capelas curadas contavam com um padre (cura) residente, que atendia às necessidades espirituais do local, sem que os moradores precisassem aguardar longos períodos sem os sacramentos ou percorrer longas distâncias até a igreja matriz da freguesia. No entanto, as capelas curadas estavam

3 Devido às longas distâncias e ao número elevado de capelas vinculados a uma paróquia, as missas e demais sacramentos aconteciam esporadicamente ao longo do ano.

$4 \quad$ Além das capelas curadas- cuja construção era realizada por um terceiro e cujo sustento advinha da renda obtida do patrimônio, existiam as capelas coladas, que eram construídas e sustentadas pela coroa. No entanto, não há na região estudada indícios deste tipo de capela. 
necessariamente subordinadas a uma freguesia e não possuíam autonomia política e administrativa.

\section{A TRANSFORMAÇÃO DAS CAPELAS EM FREGUESIAS}

Com o crescimento local, o passo seguinte na conformação do território era a transformação da capela em freguesia, o que ocorria através da sua elevação a matriz. A condição de capela curada era exigida para a implantação de uma freguesia, de forma que o instrumento político de organização territorial era vinculado formalmente ao serviço religioso. De maneira geral, o processo de elevação de uma capela ao curato acontecia concomitantemente à implantação da freguesia.

A elevação de uma capela à matriz significava a ascensão ao novo status de paróquia ou freguesia, e não implicava diretamente em alterações físicas no templo. Tal elevação não garantia apenas a assistência religiosa, mas também o reconhecimento da comunidade perante a Igreja, e, portanto, perante o Estado (MARX, 1991, p.19).

O governo local somente reconhecia a existência de uma povoação a partir do momento em que a capela presente fosse elevada à categoria de freguesia (paróquia). Esse processo para a constituição de uma nova povoação não se alterou até os fins do período imperial no Brasil. Com isso, até o final do século $X I X$, a capela era o ponto que embrionava a povoação, o primeiro símbolo de oficialidade de uma localidade que se estabelecia. Em muitos casos, também a primeira edificação do local, a edificação que atraía as pessoas para se fixarem em suas cercanias, atraindo moradores que formariam uma nova comunidade ao seu redor (VALE, 1998, p.20). [grifo nosso]

Com a presença de uma capela reconhecida pela Igreja em uma localidade, seus habitantes tinham acesso ao batismo, ao casamento, ao amparo às suas enfermidades e aos sacramentos na morte. Já com a freguesia, além destes benefícios espirituais, eles também teriam a garantia do registro de nascimento, de matrimônio, de óbito; ou seja, ao registro oficial, com todas as implicações jurídicas e sociais. Para além do acesso ao rito litúrgico, a elevação de uma capela a freguesia implicava em usufruto da formalidade civil (BUENO, 2009, p.252).

Apoiando-se nas explicações fornecidas por Murillo Marx (1991) e Cláudia Damasceno Fonseca (2011) sobre o complexo processo de formação de uma freguesia no Brasil Colonial, Fernanda Derntl (2010) esclarece:

A promoção de uma capela à condição de freguesia costumava levar em consideração critérios de ordem econômica e demográfica, embora fatores de ordem política pudessem mesmo ter preeminência. Em geral, os moradores suplicavam a elevação à freguesia alegando encontrarem-se distantes da sede paroquial e com dificuldades de caminhos. Para ser elevada a freguesia era necessário que a capela já tivesse sido então transformada em igreja matriz. As freguesias, depois de fundadas, precisavam ir demarcando seu território à medida que surgissem freguesias confinantes (DERNTL, 2010, p.66). [grifo nosso] 
Esta delimitação territorial da freguesia, com a definição de seu "termo" (limite territorial), se fazia necessária para que os moradores deste território, distribuídos em capelas e bairros rurais pudessem se organizar do ponto de vista civil, ou seja: ter direito aos registros de nascimento e óbito na sua respectiva freguesia. Decorrendo daí que na instalação de uma freguesia se criava o Livro do Tombo, onde, a partir de então, seriam feitos os registros para os moradores daquela área delimitada no seu respectivo termo. As terras do patrimônio que ainda não haviam sido demarcadas deveriam ser obrigatoriamente demarcadas e aforadas com a implantação da freguesia, criando dessa forma o que se chamava de 'fábrica' da matriz, cujos proventos eram administrados pelo fabriqueiro ${ }^{5}$. Os rendimentos destinavam-se ao sustento do clérigo e à manutenção do edifício religioso, que geralmente era reformado ou substituído por outro de proporções maiores e com técnicas construtivas avançadas, para acompanhar o crescimento da região.

\section{A CRIAÇÃO DE VILAS}

Com o crescimento da freguesia e seu protagonismo político na região, poderia ocorrer sua elevação ao status de vila. A criação de uma vila representava a integração formal do território à Coroa Portuguesa, e a criação de uma unidade territorial mínima no âmbito civil com a instalação de uma Câmara, que também poderia ser chamada de concelho. A palavra vila estava vinculada ao conjunto edificado onde estava sediada a Câmara, e como os concelhos sempre tinham sua sede numa vila, e não nas cidades, portanto, as palavras villa e concelho acabaram sendo utilizadas como sinônimos (FONSECA, 2011, p.28).

Quando a freguesia se transformava em vila, eram necessárias a construção da Casa de Câmara e Cadeia e a implantação do pelourinho, além da delimitação do rossio e do termo, fundamentais na ocupação do território e na definição do espaço urbano, distinto do espaço rural (MARX, 1991, p.91).

No ato de elevação a vila, atribuía-se, portanto, a cada um dos concelhos um termo e um rossio. O termo era todo o território de jurisdição da municipalidade, onde podia haver vários bairros e freguesias. O rossio designava os terrenos cedidos pela Coroa, por meio de carta foral, para constituir patrimônio da municipalidade. O rossio era de usufruto comum, podendo ser utilizado para pastos, plantações e obtenção de lenha. Servia ainda de reserva para a futura expansão da vila, seja para moradia ou para abertura de caminhos e praças. Competia aos edis da Câmara parcelar o rossio e arrendar as datas de terra aos moradores mediante pagamento de um imposto anual, o foro. Este modelo tradicional de organização

5 O fabriqueiro era nomeado pelo pároco para cuidar dos bens da fábrica da freguesia. A fábrica era um órgão criado pela própria Igreja assim que uma capela era elevada a freguesia. A fábrica tinha o dever de gerir o patrimônio da Igreja, especialmente de arruar e aforar os fogos (lotes) das terras pertencentes ao santo Padroeiro, e delas receber o foro anual dos moradores locais, além de administrar os valores arrecadados com ofertas e esmolas. Todo esse dinheiro era gerenciado pelo fabriqueiro, cujos proventos deveriam ser arrecadados para o sustento do pároco local e para as obras de benfeitoria no edifício da Igreja. 
local do território utilizado pela monarquia portuguesa apresentava pequenas diferenças entre sua configuração no Reino e na Colônia (DERNTL, 2010, p.74).

As cidades e vilas possuíam significados diferentes no Brasil Colônia. De maneira geral, as vilas se tornavam cidade quando eram elevadas a sede de um bispado na criação de uma diocese. No entanto, além das prerrogativas religiosas, o título de cidade era concedido a vilas relevantes do ponto de vista político ou militar, bem como as vilas litorâneas e limítrofes, que exerciam um papel de controle importante para a Coroa, a quem competia exclusivamente o papel de fundar as cidades no período colonial (FONSECA, 2011, p.29).

\section{MUDANÇAS APÓS A INDEPENDÊNCIA DO BRASIL}

Em 1822, quando foi proclamada a Independência do Brasil, a separação de Portugal implicou em expressivas mudanças governamentais. No entanto, a relação com a Igreja se manteve consolidada, onde a mesma integrou a nova forma de governo, mantendo os acordos do padroado firmados anteriormente que garantiram sua permanência e sustento nas terras brasileiras.

No que se refere a fundação e consolidação das cidades, o processo de formação urbana e criação de uma freguesia, se tornou mais rigoroso por parte do Governo Imperial, conforme a primeira Constituição Imperial promulgada em 1824. Neste processo, nada mudou em relação a Igreja; apenas os trâmites políticos tornam-se mais exigentes, pois buscavam garantir a estabilidade economica da nova freguesia. Dentre inúmeras ordens e leis proferidas para o controle das vilas e cidades, destaca-se a Lei de 15 de outubro de 1827 que determinou que todas as capelas curadas, que ainda não tivessem sido elevadas a vila, deveriam possuir o cargo de Juiz de Paz, autoridade máxima deste período, cuja função era presidir a justiça (ROSADA, 2010, p.79).

Para a elevação de uma freguesia a vila, neste caso, era necessário que a freguesia tivesse um contingente populacional maior do que era necessário no período colonial. As mudanças no trato dos espaços urbanos também são relevantes, e conforme aponta Mateus Rosada (2010), o poder de estabelecer vilas, até então do governo central, passa a ser do governo provincial:

Uma mudança administrativa ocorreu na transição da Colônia para o Império: a criação de cidades não passava mais pelo crivo do governo central. A província tinha a faculdade de estabelecê-los. Por outro lado, no passo anterior, as freguesias ainda deveriam ser aprovadas pelo imperador (ROSADA, 2010, p.92).

Quando uma freguesia era então elevada à vila, deveria, como na colônia, implantar o pelourinho e edificar a casa de Câmara e Cadeia. As câmaras neste período eram corporações 
meramente administrativas, tendo regularmente 4 sessões ordinárias anuais ${ }^{6}$. No que se refere ao espaço urbano, foram extintas as terras comunais do rossio, que eram estabelecidas para uso público pelos edis da câmara ${ }^{7}$. O mesmo não aconteceu com as terras do patrimônio religioso, que se consolidaram cada vez mais, apoiadas na Constituição Imperial que confirmava o catolicismo como religião oficial do Império Brasileiro. O patrimônio religioso continuou a ser aforado pelo fabriqueiro em favor da igreja matriz local, que em muitos casos, possuía muito mais recursos do que a Câmara.

Após a Proclamação da República em 1889, a relação da Igreja com o Governo Brasileiro foi rompida oficialmente com a promulgação da primeira Constituição Republicana em 1891. A Igreja Católica, que até então gozava de plenos poderes e era tida como religião oficial brasileira, passou a ser parte de um país considerado laico e com direito de culto a todo tipo de religião ${ }^{8}$. Extingue-se o padroado e deixa de existir o patrimônio religioso, os cemitérios são transferidos para a municipalidade e secularizados, e os casamentos válidos passam a ser gratuitos e de origem civil (SOUZA, 2004, p.405).

De todo modo, o Brasil majoritariamente católico duvidou, num primeiro momento, do regime republicano laico. A Igreja continuou a gozar de seus benefícios, do patrimônio construído até então, e de sua influência política dentro das cidades. As pessoas continuaram a exercer suas atividades religiosas e a financiar as obras da Igreja, que, mesmo com a extinção do patrimônio religioso, continuou a receber doações de terrenos em novos loteamentos e a contar com o auxílio da iniciativa privada- principalmente industriais e grandes produtores rurais- na construção ou reforma de seus templos.

A Igreja também aproveitou para se renovar e desvincular-se da imagem de um órgão de estado. Inicia-se neste período um processo de romanização, cujo intuito era aproximar-se do Papa e de seus ensinamentos, que devido ao beneplácito ${ }^{9}$ do Imperador, teve boa parte de seus documentos e encíclicas barrados pela Coroa no período do padroado. O processo de renovação da Igreja, que já era ensejado por bispos e padres desde a metade do século $X I X$, estava ancorado na valorização dos sacramentos e dos preceitos religiosos, voltando a Igreja para um caráter mais sacro do que político. A centralização da Igreja em Roma, e no seu representante, o Papa, cuja infalibilidade não deveria ser questionada, aproxima-se do

6 As câmaras podiam ainda convocar reuniões extraordinárias dependendo da necessidade. In: (ESTADO DE SÃO PAULO, 1954, p.219).

$7 \quad$ Os edis eram os vereadores da época, cuja função era zelar pelo bem público e comandar as obras públicas da cidade, numa fusão de legislativo e executivo, funções que foram desmembradas com a República. 8 Apesar do catolicismo ser a religião oficial do Brasil, os protestantes já estavam no Brasil desde a abertura dos portos e do processo de imigração.

$9 \quad$ O beneplácito consistia em um instrumento instituído junto com o padroado, que permitia ao Imperador vetar a chegada e a circulação de documentos, materiais e ensinamentos oriundos da Santa Sé. 
ultramontanismo ${ }^{10}$, desejado pela ala tradicional da Igreja.

A criação de cidades, no entanto, competia exclusivamente ao Congresso do Estado ${ }^{11}$ e estava totalmente desvinculada da criação de paróquias, ação que agora competia apenas à Igreja. No período republicano, criam-se municípios, cuja sede é sempre uma cidade, e as freguesias do período colonial e imperial passaram a ser chamadas de 'distrito de paz'. A única diferença, no entanto, é que a sede do distrito de paz é sempre uma vila.

A Constituição Republicana de 1891 determinava que, para um distrito de paz ser elevado a cidade, era necessário o preenchimento de uma série de itens e normativas, cujo intuito era garantir a sobrevivência da municipalidade. Para que se estabelecesse como tal, a população mínima deveria ser de 10 mil habitantes em todo o território do futuro município, e a sede deveria ter pelo menos 100 edifícios bons e 1.000 habitantes, além de um orçamento mínimo de 20 mil cruzeiros (ESTADO DE SÃO PAULO, 1954, p.220). Ao contrário dos períodos anteriores, não era mais exigida a edificação de uma igreja matriz, mas sim a existência de duas escolas e da cadeia pública. As câmaras que, até então, tinham função administrativa, passaram a ter função legislativa, e para o serviço administrativo foi instituído o cargo de prefeito, que tornou o funcionamento das cidades semelhante ao que temos atualmente.

\subsection{CAMINHOS, IGREJAS E FERROVIAS: SURGEM AS CIDADES}

A ocupação do sertão paulista ocorreu paulatinamente ao longo dos séculos, sempre partindo do litoral para o interior, nas faixas de terra ainda não habitadas ou conhecidas. Um grande impulso de desenvolvimento acontecerá no século XIX, a partir da concessão de novas terras sertão adentro e do crescimento do número de engenhos e canaviais, que posteriormente foram substituídos pelos cafezais no final do século. A concessão de sesmarias ao longo do eixo do Caminho dos Goyazes e a utilização dos rios, através de sua força e navegabilidade, potencializaram o desenvolvimento de uma região promissora, com terras férteis e vastas, onde se formaram núcleos de povoamento e suas respectivas capelas.

Posteriormente, a chegada de infraestruturas, como o trem, a indústria e a rodovia, fomentou o desenvolvimento de novas localidades e o crescimento das primitivas, criando desta forma um território complexo, com regionalidades e especificidades cujos detalhes serão apresentados a seguir.

\section{A OCUPAÇÃo DA REGIÃO E AS POVOAÇÕES DA 1Ạ. METADE DO SÉCULO XIX}

10 O ultramontanismo foi motivado pelo Papa Pio IX numa tentativa de desvincular as igrejas nacionais, que estavam contaminadas do liberalismo vigente (inclusive a Maçonaria) e subordinadas ao Estado, buscando assim, uma unidade religiosa e centralizando-a no papado. Este processo culminou na promulgação do Concílio Vaticano (1869-1870).

11 Equivalente a Assembleia Legislativa. 


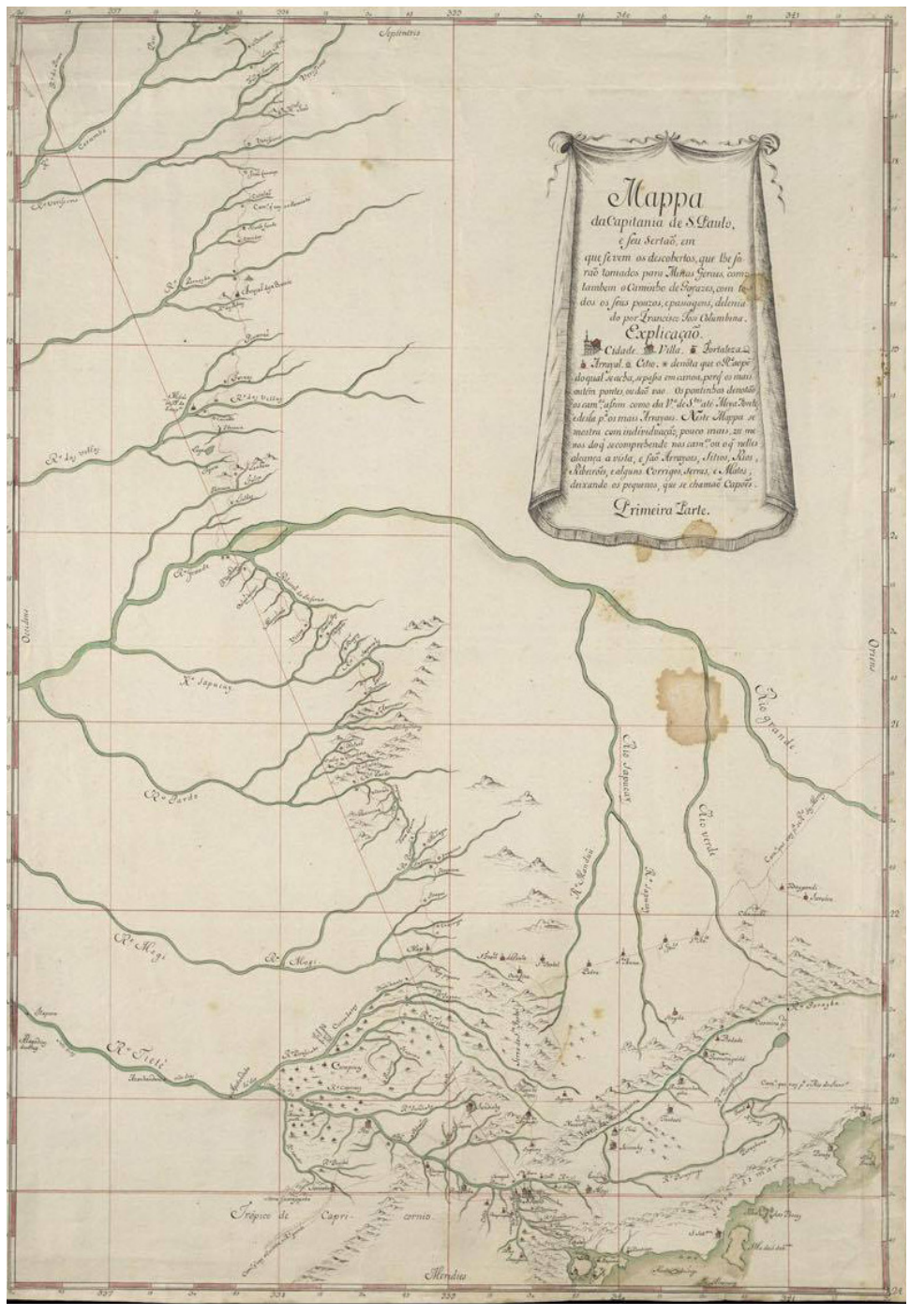

A região que hoje compreende a divisão territorial eclesiástica da Diocese de Limeira - nosso objeto de estudo - possui cidades com gênese e formação urbana variada sob diversos aspectos. De maneira geral, as mais antigas surgiram no início do século XIX e foram elevadas a cidade no período imperial. Via de regra, a maioria localiza-se no eixo do antigo Caminho do Goyazes, tendo seus primeiros povoados juntos a ranchos de pouso, sendo cortadas atualmente pela Rodovia Anhanguera (SP330).

Figura 03: Mapa da Capitania de São Paulo e seu sertão de autoria de Francisco Tosi Colombina (século XVIII), com destaque para o Caminho dos Goyazes e seus ranchos de pouso ao longo do caminho. Fonte: Biblioteca Nacional.

Após a descoberta de jazidas auríferas em Goiás por Bartolomeu Bueno da Silva, houve um grande fluxo de aventureiros que transitavam entre Jundiaí e Goiás em busca de minérios, já que "era da antiga vila de Piratininga, de Itu, de Araritaguaba e de Jundiaí que partiam as bandeiras mineradoras para Mato Grosso e Goiás e as linhas do seu abastecimento e comercio" (MELLO PUPPO, 1969, p.14).

Com isso, entre 1722 e 1725 se criou o Caminho das Minas dos Goyazes que ao longo dos anos foi percorrido por viajantes de todas as classes e procedências na esperança de enriquecimento e gerou muitos pedidos e concessões de sesmarias ao longo de seu traçado. No século XVIII, abriam-se, enfim, as estradas do Viamão e do Goiás, renovado "o velho caminho das bandeiras do Anhanguera, passado por Campinas e Franca" (MELLO PUPPO, 1969, p.14). 


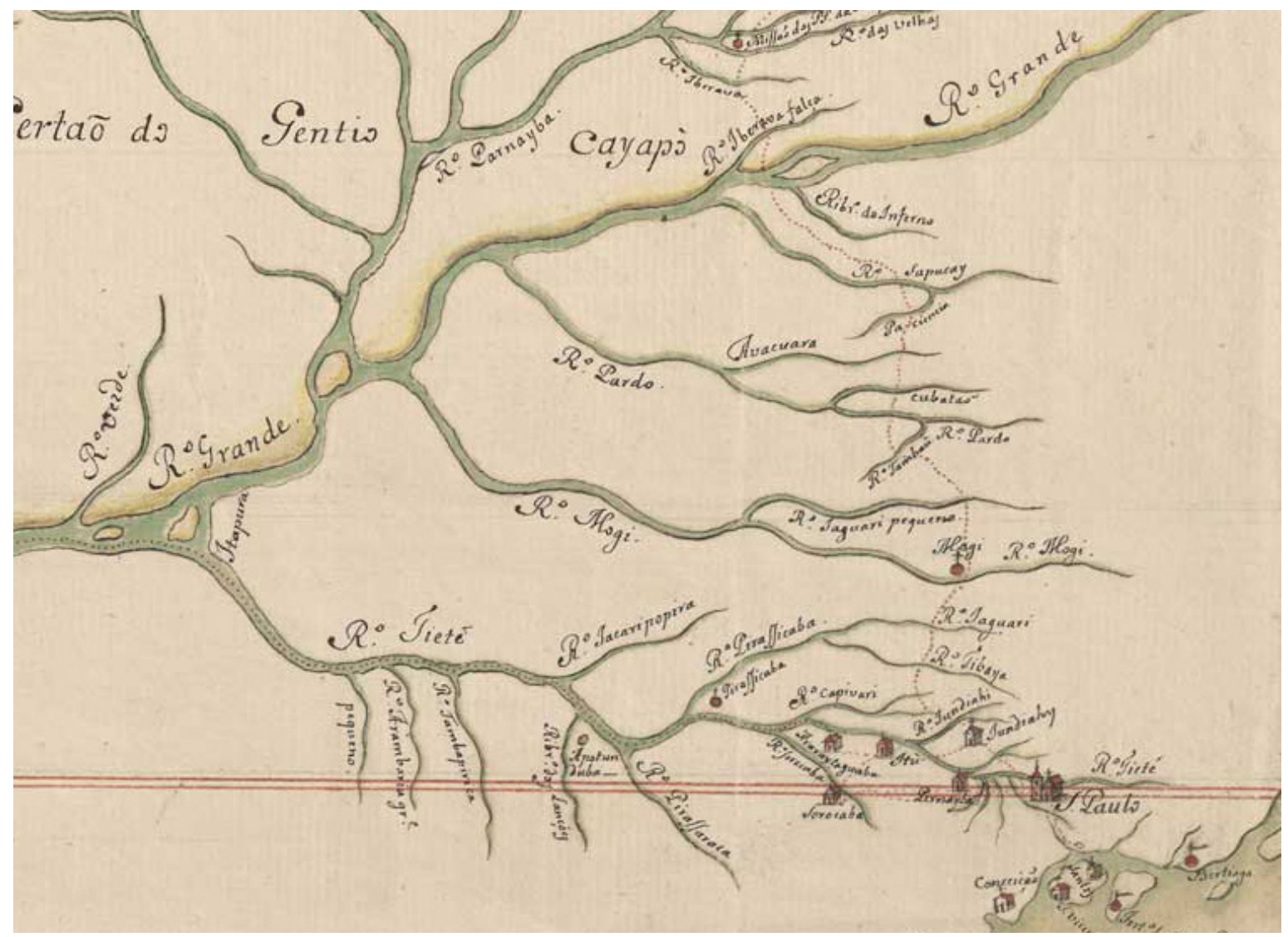

Figura 04: Ampliação de outro mapa da Capitania de São Paulo, com destaque para a hidrografia e o Caminho dos Goyazes (em tracejado) partindo de São Paulo. Fonte: Biblioteca Nacional.

No fim do século XVIII, as lavouras canavieiras já haviam começado a penetrar "áreas serra acima". A Vila de Itu e sua região apresentavam rápida expansão da cultura do açúcar e, impulsionada por esta economia agrícola, ocorre a autonomia administrativa, a partir da gestão do governador da Capitania de São Paulo, D. Luís Antônio de Souza Botelho Mourão, o Morgado de Mateus, (1765-1775), com a adoção de uma política de povoamento da capitania. Esta política de povoamento consistia em estabelecer novas povoações com lavouras ao redor, onde surgiram os engenhos de açúcar; através de cartas de doação que autorizavam os donatários a repartir as terras da sesmaria a "qualquer pessoa de qualidade e condição", sem pagamento de foro ou dízimo (MOURA FILHA, 2010, p.24).

No final do século XVIII, Itu se consolidava como um território açucareiro. Em 1798, existiam em Itu 107 engenhos que produziam 64.809 arrobas de açúcar. No ano seguinte, o número de engenhos elevou-se para 113 com uma produção de 73.506 arrobas de açúcar, constituindo a atividade principal da vila (PETRONE, 1968, p.121). O desenvolvimento da cultura do açúcar na Freguesia de Nossa Senhora dos Prazeres, pertencente ao termo da Vila de Itu, vai contribuir para o seu desmembramento em 1822, passando a designar-se Vila de Constituição (atual cidade de Piracicaba). Desmembramentos territoriais posteriores da Vila de Constituição originariam uma nova rede de vilas na região, ainda na primeira metade do 
século XIX, dentre elas a vila de Limeira, cuja capela foi construída na região do Morro Azul e do rio Piracicaba em período concomitante à construção das capelas que deram origem às cidades de Pirassununga e Descalvado, em região mais ao norte, no território de Mogi Mirim e Araraquara. Já o povoado de Santa Cruz da Conceição, que surge anos mais tarde, apresentou um crescimento lento, fazendo com que cidades que surgiram décadas depois, como Araras e Leme, adquirissem um protagonismo e uma relevância política maior.

A chegada da ferrovia fez com que o cenário urbano mudasse completamente, e as cidades sofressem um salto de desenvolvimento e crescimento. Com isso, surgiram novas localidades, como Americana, Cordeirópolis, Analândia e Porto Ferreira, originária do encontro do trem com o rio. As novas infraestruturas urbanas e regionais somadas à chegada de empresários e industriais, bem como as políticas de ocupação e desenvolvimento territorial, fizeram surgir as novas cidades do século XX, cuja gênese e evolução urbana são totalmente diferentes das vivenciadas até então, como nos casos de Nova Odessa, de Iracemapólis e das cidades da região do Funil, Cosmópolis, Artur Nogueira, Engenheiro Coelho e Conchal, conforme apresentado a seguir.

\section{FREGUESIA DE NOSSA SENHORA DAS DORES DO TATUIBI E A VILA DE LIMEIRA}

Como vimos, o município de Limeira tem sua origem nas expedições de Bartolomeu Bueno da Silva, o Anhanguera, que ao adentrar o sertão paulista em direção às minas do atual território de Goiás, foi criando diversos pousos pelo caminho para o descanso das tropas e dos animais. Geralmente, tais pousos localizavam-se em clareiras, abertas em meio à mata, próximo a um córrego d'água, como aconteceu na região de Limeira, onde o rancho foi montado junto ao Ribeirão Tatu, num local chamado sertão do Tatuibi

Os primeiros registros de ocupantes oficiais na região de Limeira acontecem no fim do século XVIII e início do século XIX, com a doação de sesmarias a vários proprietários ao longo do Caminho dos Goyazes. A principal delas é a sesmaria do Morro Azul, onde estavam instalados importantes e grandes engenhos de açúcar, entre elas o Engenho Ibicaba e o Engenho do Tatu.

As primeiras safras de cana de açúcar nas terras dos sesmeiros da região do sertão de Tatuibi datam de 1815 em diante. Foi neste mesmo período, sem data precisa, que os registros apontam que o Capitão Luiz Manoel da Cunha Bastos comprou do Coronel Sá, de São Paulo, o Engenho do Tatu, que abrangia a região onde se localizava o rancho de tropeiros instalado pelo Anhanguera. Mais tarde, Cunha Bastos compra do Tenente Ignácio de Sá um trecho da sesmaria do Pirapitingui - área que vai da região do Ribeirão Tatu até a atual cidade de Cosmópolis-, anexando então essas terras ao Engenho do Tatu (BUSCH, 2007, p.41). 


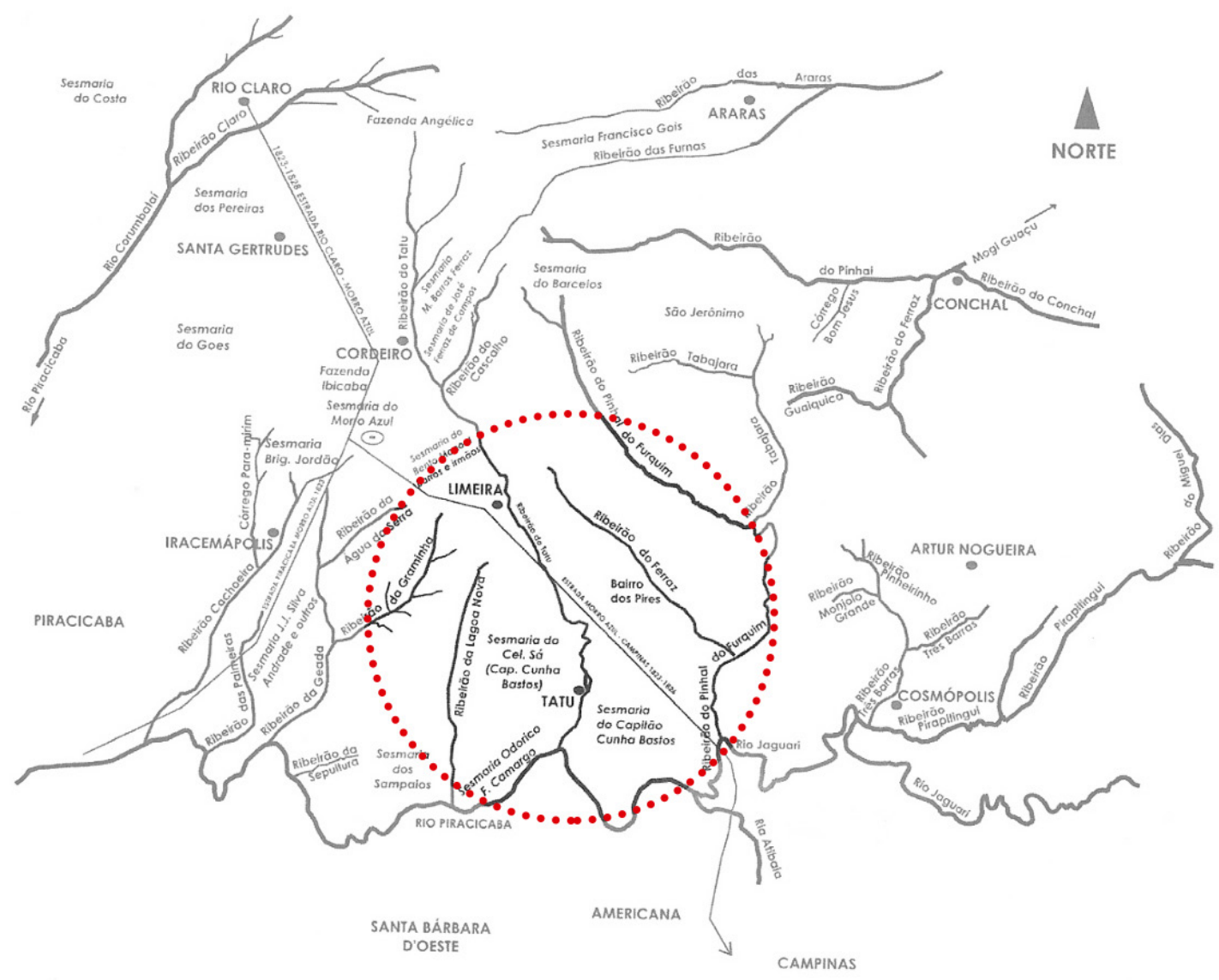

Figura 05: Mapa da Região de Limeira com as principais sesmarias presentes. Em destaque; a região, onde hoje se encontra a cidade de Limeira e o engenho do Tatu. Fonte: BUSCH, 2007.p.43. Elaborado pelo autor.

A povoação de Limeira começou, portanto, com a vinda de senhores e a instalação de engenhos para produzir na região, cuja fertilidade das terras já era conhecida entre quilombolas e indígenas. Pelo censo de 1822, a região onde hoje se localiza Limeira já contava com 951 pessoas livres, entre sesmeiros, proprietários de engenhos, sitiantes e posseiros, além de 546 escravos (BUSCH, 2007, p.47).

Devido à produção dos engenhos e do caminho dos Goyazes, os senhores de terras conseguiram junto ao Governo Provincial em 1823 a autorização para abertura de uma estrada ligando o Morro Azul a Vila de São Carlos - atual Campinas-, e Vila de Constituiçãoatual Piracicaba-. Acredita-se que esta grande estrada para o escoamento da produção dos engenhos tenha sido fundamental para a formação inicial do espaço da futura Limeira, uma vez que ao redor dela foram se estabelecendo diversos tipos de comércios e pousos para os viajantes, além do já presente rancho de tropeiros.

Com a formação de um aglomerado populacional junto à Estrada Geral recém-aberta, foi 
pedido ao proprietário das terras então ocupadas, Capitão Cunha Bastos, a autorização para a construção de uma capela sob invocação de Nossa Senhora das Dores. Dados da Cúria Metropolitana de São Paulo apontam que a Igreja concedeu em 1826 a autorização para a edificação de uma capela na região do sertão do Tatuibi. Para o bom êxito desta construção, Bento Manoel de Barros, o Barão de Campinas - que acabara de se mudar da cidade de Itu para a região do Tatuibi - doou quantias generosas que se somaram aos donativos da população (CARITÁ, 1998, p.17).

Pouco se sabe sobre a arquitetura da primitiva capela, além de sua localização no Largo da Matriz, entre as ruas Augusta, ou rua debaixo do páteo- atual Barão de Cascalho- e Travessa da Matriz - atual Barão de Campinas. A técnica construtiva empregada foi a taipa de mão. Sabemos que a mesma possuía telhado em duas águas e uma pequena torre lateral. No seu interior possuía pinturas que não agradaram a Hercules Florence, conforme trecho de seu livro Viagem Fluvial do Tietê ao Amazonas de 1825 a 1829 que dizia: "devo acrescentar que vi mais tarde, na Igreja de Limeira, imagens e quadros de tão abominável execução como as figurinhas que se encontram nos quilombolas dos negros, isto é, manipansos de feitiçaria" (FLORENSE apud ROSADA, 2010, p.135). Além disso, nos relatos de alguns colonos do Engenho Ibicaba, aparece também o descontentamento com a capela que possuía "santos feitos de barro e tecido lustroso" (CARITÁ, 1999, p.91).

Devido ao crescimento da região e sua localização estratégica, foi submetido em 1829 ao Governo Imperial o pedido de elevação da então Capela de Nossa Senhora das Dores ao status de freguesia. O processo que passou pelas mãos do Bispo Diocesano de São Paulo e do pároco da Paróquia Santo Antônio da Vila de Constituição, recebeu parecer favorável, e então, em 09 de dezembro de 1830, o Imperador Dom Pedro I sancionou a lei que criou a Freguesia de Nossa Senhora das Dores do Tatuibi (ROSADA, 2010, p.64).

Com a criação da freguesia, em 03 de fevereiro de 1831 foi celebrada a missa solene para a instalação da freguesia e criação da Paróquia Nossa Senhora das Dores do Tatuibi, que passou a ser curada e a desempenhar um papel administrativo dentro do espaço urbano. Sendo assim, a população que habitava na região não precisou mais se deslocar até a paróquia mais próxima para realizar seus serviços religiosos e civis, que se tornaram competência da nova paróquia.

Para que a nova freguesia se consolidasse, seguindo o procedimento herdado do Brasil Colônia, que se manteve na constituição imperial, era necessário que o então proprietário destas terras, no caso o Capitão Luiz Manoel da Cunha Bastos, oficializasse a doação das terras onde estava a nova matriz, que constituíam o patrimônio de Nossa Senhora das Dores, doado com a criação da capela. As normas para a doação destas terras estabeleciam 
que estas fossem de forma quadrada, sendo a igreja matriz implantada no largo ao centro da gleba doada (MARX, 1991, p.73). Após a construção da igreja, lançavam-se as medidas respeitando seu alinhamento; no caso de Limeira, o patrimônio doado era um quadrado cujos lados mediam aproximadamente um quarto de légua (1.650m). O documento de doação foi assinado e lavrado por Cunha Bastos na sede do Engenho Ibicaba ${ }^{12}$, propriedade de Nicolau Pereira de Campos Vergueiro, conhecido como Senador Vergueiro, que, com a doação oficial destas terras e a instalação da Freguesia, passou a ser o Mordomo da Sociedade do Bem Comum de Limeira, assumindo assim o ofício de fabriqueiro:

[...] que como um prefeito nos dias de hoje, deveria planificar e arruar o povoado, aforar, arrendar, vender ou alienar os lotes de terreno, reservando áreas para o uso público e destinando as rendas ao patrimônio de Nossa Senhora das Dores (BUSCH, 2007, p.107).

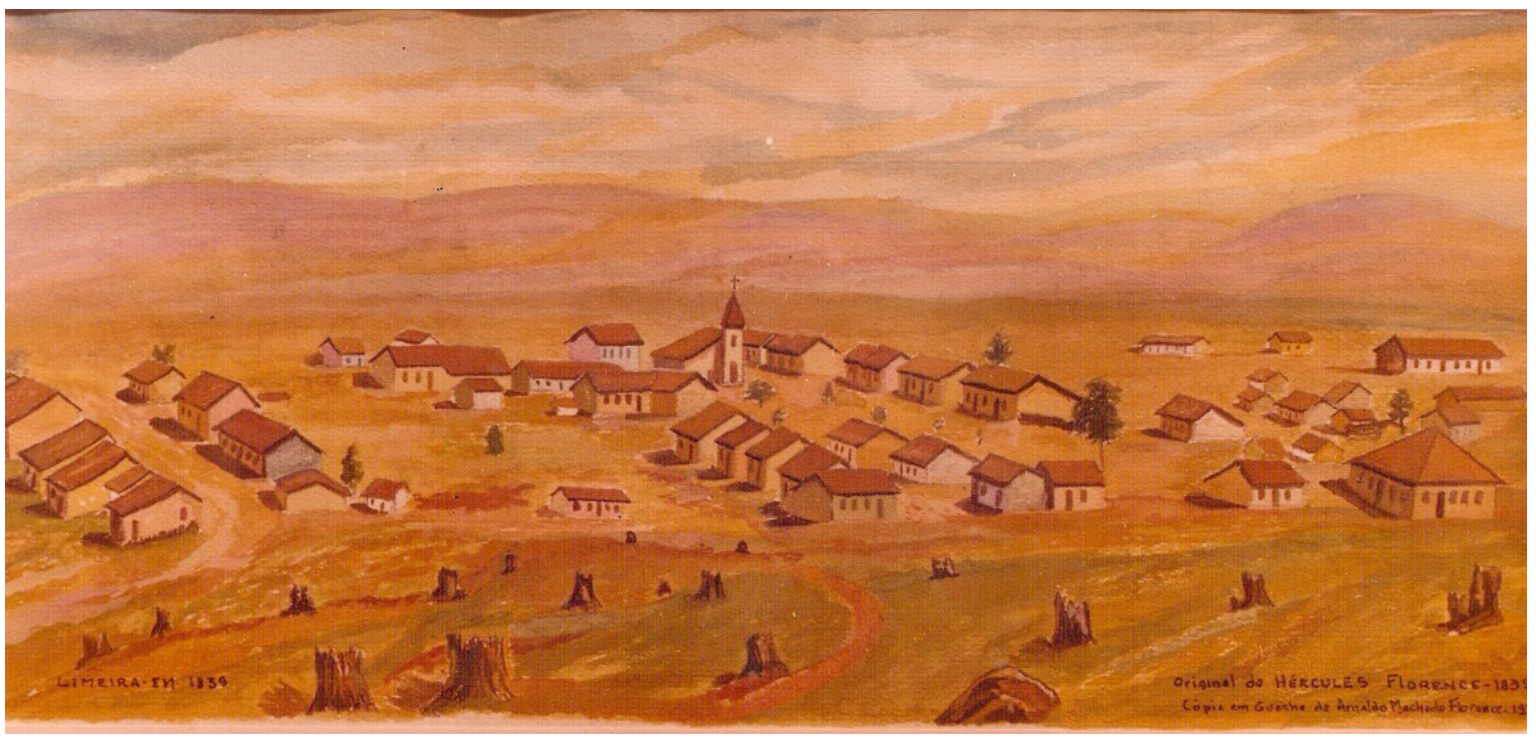

Figura 06: Limeira em 1839, notando-se a Igreja Matriz ao centro do povoado. Cópia em guache de Arnaldo Machado Florense em 1970 de desenho de Hercules Florense de 1839. Fonte: Acervo do Museu Histórico e Pedagógico Major José Levy Sobrinho.

Neste momento, surgiram as primeiras ações de planejamento do espaço urbano, cuja morfologia ainda é reconhecível na área central de Limeira. Sabe-se que o então fabriqueiro deu ordens precisas quanto ao arruamento de Limeira, tal como fez para Rio Claro e Piracicaba ${ }^{13}$, obedecendo ao sistema das quadrículas ortogonais hipodâmicas, estabelecidas como regra desde o governo de Morgado de Mateus. As medidas adotadas para a Freguesia do Tatuibi foram as seguintes: "quadras de 1.600 braças [7.744m²], quarteirões de 40 braças [88m] e ruas de 60 palmos [13,20m] de largura" (BUSCH, 2007, p.107).

12 Não há registro dos motivos que fez com que assinatura ocorresse em tal lugar. A relevância e influência política do Senador Vergueiro pode ter sido decisiva para tal ato.

13 Rio Claro e Limeira foram fundadas ao mesmo tempo, em 1826 e 1827 respectivamente. Enquanto Piracicaba, que havia sido fundada no Governo de Morgado de Mateus, foi transferida em 1821 para a margem oposta do Rio, assumindo assim um novo traçado. 
Com o crescimento populacional, a freguesia passou a almejar o status de vila, último grau concedido aos espaços urbanos na constituição vigente, que, como mencionado anteriormente, exigia um contingente populacional maior para ser obtido. Neste caso, cabia ao Governo Provincial de São Paulo averiguar o pedido feito pela população e pelas autoridades locais (ROSADA, 2010, p.91). A elevação a vila traria inúmeros benefícios à região, entre elas a presença da Casa de Câmara e Cadeia. Assim, na sessão de 29 de janeiro de 1842 da Assembleia Legislativa Provincial, foi feito o pedido de elevação da Freguesia de Nossa Senhora das Dores de Tatuibi a vila, que, com o parecer favorável dos deputados da casa, foi aceito e sancionado em lei no dia 08 de março de 1842 (BUSCH, 2007, 159). Cabe mencionar que a nova vila foi denominada "Vila de Limeira", nome diverso do seu nome de freguesia, o que era pouco usual ${ }^{14}$.

Porém, devido a instabilidades no Governo Imperial, a instalação efetiva da Câmara da Vila de Limeira deu-se apenas em 22 de julho de 1844, dois anos depois de sua elevação a vila. Foram então anexadas ao seu termo as freguesias de São João Batista do Rio Claro e do Senhor Bom Jesus dos Aflitos de Pirassununga, que posteriormente foram elevados a vila ${ }^{15}$. A vila de Limeira foi elevada ao status de cidade em 18 de abril de 1863.

\section{OUTRAS CIDADES DA PRIMEIRA METADE DO SÉCULO XIX}

Além de Limeira, outras três cidades têm sua gênese na primeira metade do século XIX: Pirassununga e Descalvado, mais ao norte, próximas ao rio Mogi Guaçu, e Santa Cruz da Conceição, na região mais central do território estudado, cujo desenvolvimento é precário e moroso ao longo do tempo, contrapondo-se às demais cidades da região. A Capela de Santa Cruz da Conceição será a única capela que será elevada apenas ao curato, sem a criação conjunta de uma freguesia, cuja ação surtirá resultados negativos para o desenvolvimento local, que serão notados ao longo de toda sua história.

\section{FREGUESIA DO SENHOR BOM JESUS DOS AFLITOS DE PIRASSUNUNGA}

A cidade de Pirassununga, cuja Freguesia foi incorporada ao território da Vila de Limeira em 1842, tem sua origem em 1823 com a construção de uma igreja dedicada ao Senhor Bom Jesus dos Aflitos nas terras doadas por Ignácio Pereira Bueno e sua esposa Anna Francisca da Silva, moradores do termo da Vila de Mogi Mirim (GODOY, 1975, p.13). Em 1828, a igreja construída será visitada pelas autoridades eclesiásticas e anexada à Freguesia de São José de Mogi Mirim, sendo elevada a freguesia somente em 4 de março de 1842, quando

14 Tal fato é explicado através dos primeiros registros feitos pelo pároco da matriz, que se referia ao local como "Freguesia da Limeira", talvez em referência ao rancho de tropeiros que deu origem à ocupação da região, conhecido como Rancho da Limeira.

15 A cidade de Rio Claro foi desmembrada de Limeira pela Lei 13 de 07 de março de 1845. 
foi oficializada a doação do patrimônio ao Senhor Bom Jesus dos Aflitos. A ereção a vila aconteceu em 22 de abril de 1865 e sua elevação a cidade em 31 de março de 1879 (ESTADO DE SÃO PAULO, 1954, p.159).

\section{FREGUESIA DE NOSSA SENHORA DO BELÉM DO DESCALVADO}

A atual cidade de Descalvado, cujo território pertencia à Vila de Araraquara, principiou-se com a construção de uma capela dedicada à Nossa Senhora do Belém em 1832, cuja escritura de doação do patrimônio foi lavrada em 10 de novembro de 1842. Em 28 de fevereiro de 1844, foi elevada ao status de Freguesia de Nossa Senhora do Belém do Descalvado, passando a integrar o termo da Vila de Mogi Mirim. Com a elevação de Rio Claro a Vila em 1845, a Freguesia de Belém do Descalvado foi desincorporada do termo da Vila de Mogi Mirim e passou a compor seu termo, da qual foi desmembrada em 28 de abril de 1865, quando foi elevada a vila. Sua elevação a cidade aconteceu em 01 de abril de 1889 (BELLI, 1997, p.08).

\section{A CAPELA DE SANTA CRUZ E A PARÓQUIA DA IMACULADA CONCEIÇÃO}

A região do atual município de Santa Cruz da Conceição, compreendida entre a Freguesia do Senhor Bom Jesus dos Aflitos de Pirassununga e a Freguesia de São João Batista do Rio Claro, foi ocupada paulatinamente por sesmeiros e pequenos produtores rurais. A região, que já foi ocupada por pequenos grupos de quilombolas e indígenas, começou a ser ocupada oficialmente a partir de 1830.

Em geral, a região foi ocupada por pequenos produtores de arroz, milho e feijão, que se instalaram próximos ao Ribeirão do Roque. No entanto, boa parte destes moradores não eram os proprietários das terras em que ocupavam, mas moravam de favor e nela produziam para seu sustento.

O ato embrionário do que viria a se tornar a cidade de Santa Cruz da Conceição, foi a construção em 1835 de um pequeno rancho de comércio, e a colocação de uma cruz no cruzamento da estrada que ia da Freguesia de Pirassununga até a Freguesia de Rio Claro, pelo então proprietário das terras Jacinto Rodrigues de Moraes e sua esposa Luzia de Sousa (CORRÊA, 2005, p.25).

A cruz logo foi substituída por um rancho que servia de capela para oração da população local e dos viajantes. Em 1840, o rancho foi refeito e recebeu uma nova cobertura, agora de telhas. Porém, com o crescimento da população local, surgiu o desejo de que esta capela passasse a receber o atendimento religioso do vigário de Pirassununga, por isso, em 1842, o rancho é totalmente demolido e é construída a primeira capela de Santa Cruz (TOMBO I. NSC. p.10). 
A primeira missa foi celebrada em 3 de maio de 1843 e a capela foi anexada a Freguesia do Senhor Bom Jesus dos Aflitos de Pirassununga. Ao contrário das outras cidades já apontadas, a Capela de Santa Cruz ficará muito tempo sendo atendida pela paróquia de Pirassununga, devido ao contingente populacional muito baixo para sua elevação ao grau de freguesia.

No entanto, a população local almejava a presença constante de um sacerdote para dispensar os sacramentos e obter reconhecimento oficial perante o Estado com a instalação da freguesia, adquirindo desta forma legitimidade sobre a terra e autonomia para seu desenvolvimento. A região apresentava um leve crescimento, mas ainda assim muito incipiente para a realização de tal feito, o que torna moroso o processo para a consolidação da freguesia.

Eram de conhecimento de todos os protocolos exigidos pela Igreja e pelo Governo Imperial para a instalação e criação de uma paróquia. A doação do patrimônio oficializaria o desejo da população local e incentivaria a Igreja a querer ocupar-se de fato destas terras com a implantação de uma nova freguesia. Desta forma, João Francisco Cardoso, que já residia no local trabalhando com a manufatura do milho, compra em 1868 as terras onde estava construída a ermida de Santa Cruz dos herdeiros de Jacinto Rodrigues de Sousa e Luzia de Sousa. Na ata de constituição do patrimônio de Nossa Senhora da Conceição disposta no livro tombo da paróquia, existem 8 escrituras de venda do espólio de Luzia de Sousa pelos seus herdeiros, cuja frações de terras foram se somando, totalizando 23 alqueires e meio.

Dizemos, nós abaixo assignados, eu Francisco Antônio Cardoso, e minha mulher Maria Rosa de Sousa, que é verdade que entre os mais bens que somos detentores e possuidores, livre, e desembargados com geral administração, e bem assim, uma pequena parte de terras, que nós tocou pelo falecimento de nossa mãe e sogra, Luzia de Sousa, na paragem denominada Santa Cruz do Ribeirão do Roque, distrito da Vila do Senhor Bom Jesus dos Aflitos de Pirassununga, de cuja parte de terras acima declaradas vendemos tão somente a quantia de três alqueires de milho medido em terra ao Sr. João Francisco Cardoso para que Ihe damos plena e geral quitação pelo preço e quantia de trinta mil reis, ficando ele comprador a pagar obrigador a pagar a lira Nacional, e poderá ele dito senhor comprador de hoje em diante possuir, dar, vender, ou alienar, fazer delas o que muito bem Ihe parecer como suas que ficão sendo, por si e seus herdeiros, ascendentes ou descendentes, e que herdeiros nenhuns nossos possão derrogar esta nossa carta de venda por ser muito de nossa livre vontade, sem constrangimento de pessoas algumas, e se, nela faltar alguma clausula ou clausulas das em direito necessárias, nós obrigamos a fazer boa e valiosa a todo tempo que nós for pedido, tanto em juízo, como fora dele, e pedimos a justiça de Sua Magestade Imperial Ihe faça dar inteiro vigor e valimento como se fôra uma escriptura púbica, e por assim ser verdade do referido passo apresente pelo meu próprio punho, e firmo, e a rogo de minha mulher assigna o senhor Jacinto Raiz de Moraes.

Santa Cruz do Ribeirão do Roque, 11 de julho de 1868 (TOMBO I. NSC. Anexos).

Esta mesma escritura foi lavrada 8 vezes, de acordo com cada pedaço de terra herdada pelos filhos. No final de cada documento, o comprador, João Francisco Cardoso, passou-as diretamente para compor o patrimônio de Nossa Senhora da Conceição na região de Santa 
Cruz do Ribeirão do Roque:

Declaro que de minha livre e espontânea vontade, faço doação das terras que faz menção o presente título, à Nossa Senhora da Conceição para seu patrimônio.

Pirassununga, 23 de julho de 1868. A rogo do doador: João Francisco Cardoso (TOMBO I. NSC. Anexos).

Apesar da oficialização da doação, cuja visita para fiscalização das terras doadas foi realizada pelo vigário geral da Diocese de São Paulo em 28 de abril de 1869 (TOMBO II. NSC. p.11), a região não possuía capacidade de sustentar uma freguesia e nem as côngruas de um padre, nem mesmo com o aforamento dos lotes do patrimônio. Além disso, a primeira capela era muito pequena para acomodar os fiéis nas missas que aconteciam esporadicamente, por isso em 1870, após uma campanha popular foi abençoada a pedra fundamental da construção de uma nova capela, que ficou pronta e foi inaugurada 2 anos depois.

Findada a construção e após inúmeros pedidos feitos pela população, em 16 de agosto de 1876 a capela foi elevada ao grau de curato, que determinava a presença de um padre no lugar, mas sem o status de freguesia (CORRÊA, 2005, p. 26). A presença de um religioso garantiria o acesso as práticas religiosas, porém as atividades civis ainda eram dispensadas pela paróquia de Pirassununga.

A freguesia, cujo status era almejado pela população local só foi criada em 3 de março de 1879 e instalada em 23 de janeiro de 1881 (TOMBO I. NSC. p.36), 13 anos depois da doação do patrimônio, e seu território anexado a Vila de Araras até 1883, quando retornou para o termo da Vila de Pirassununga.

Contudo, na última década do século XIX, a então freguesia de Nossa Senhora da Conceição de Santa Cruz - que devido à separação entre Igreja e Estado decorrente do advento da República, havia se transformado no Distrito de Paz de Santa Cruz da Conceição-, passou de 6.787 habitantes em 1890 para 14 mil habitantes em 1898 (CORRÊA, 2005, p.45). Explicase tal aumento populacional principalmente pela chegada maciça de imigrantes no último quartel do século XIX para o manejo das lavouras de café, produzido em larga escala nas propriedades da região. Tal fato, possibilitou que em 14 de julho de 1898, o Distrito de Paz fosse elevado a município (ESTADO DE SÃO PAULO, 1954. p.181).

Porém, devido a mudanças no trajeto do ramal ferroviário, cujos detalhes serão apresentados no item a seguir, a cidade experimentou um processo de esvaziamento que acabou por fazer com que, em 21 de maio de 1934, o Governo Estadual determinasse que a cidade fosse reconduzida à condição de Distrito de Paz, sendo anexada ao município de Leme. Somente em 30 de dezembro de 1953 Santa Cruz da Conceição retomou o status de município. 


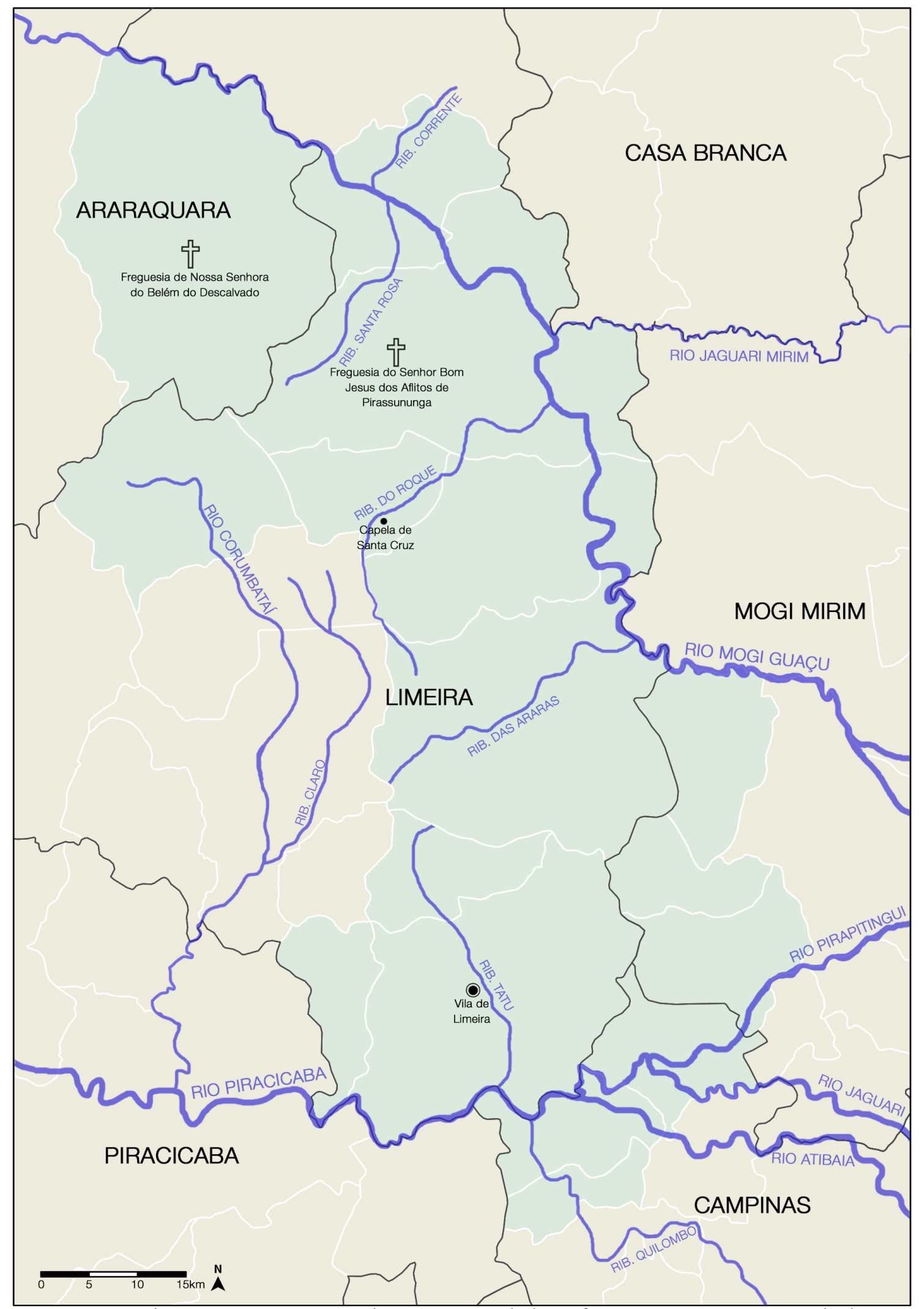

Figura 07: Mapa da Região em 1850, com destaque para a hidrografia presente na região e a Vila de Limeira e seu extenso termo, no qual estavam as freguesias de Descalvado e Pirassununga e a Capela de Santa Cruz, próxima do Ribeirão do Roque. A região em verde trata-se do território onde surgirão as cidades que serão integrantes da Diocese de Limeira, cujas divisas atuais são mostradas em linha branca, enquanto as divisas da 
época estão em linha preta. Nota-se os extensos territórios que possuíam as vilas. A vila de Limeira ocupava quase todo o território onde se formou a Diocese homônima. Fonte: Elaborado pelo autor. Baseado em: Fundação Seade (2000) e CESAD FAU.

\section{A TRANSFORMAÇÃO DA REGIÃO E AS POVOAÇÕES DA 2. METADE DO SÉCULO XIX - AS CIDADES QUE NASCERAM ENTRE 1850 E 1870}

Nas primeiras décadas da segunda metade do século XIX, o estado de São Paulo manterá sua característica agrícola. Com a obsolescência dos primeiros cafezais e o esgotamento das terras do Vale do Paraíba, onde a cultura do café ganhou força na primeira metade do século XIX, novas fazendas irão surgir sertão adentro para suprir a demanda da produção cafeeira. Devido à disponibilidade e qualidade das terras da região central do estado ${ }^{16}$, as propriedades rurais, que até então produziam de tudo um pouco, visando o pequeno comércio interno e a sobrevivência, começarão a produzir café em larga escala tendo em vista a exportação.

Para que a produção cafeeira se consolidasse e fortalecesse, eram necessários empreendimentos que facilitassem o escoamento da produção da região para o porto de Santos, visando substituir o carregamento realizado até então, por tropas de muares e picadas em estradas de terra. Este processo, muito rudimentar, custoso e demasiadamente moroso, era um verdadeiro entrave para a produção cafeeira, pois, encarecia e dificultava a exportação. Com isso, as linhas ferroviárias que até então serviam apenas os centros urbanos já consolidados, recebem aval do Governo Imperial para serem expandidos sertão adentro, rasgando desta forma o território em direção a novas localidades. A expansão dos ramais ferroviários e chegada da ferrovia possibilitaram a formação de novos núcleos urbanos como nos exemplos mostrados a seguir.

\section{A CONSTRUÇÃO DA ESTRADA DE FERRO PAULISTA - SURGEM NOVAS CIDADES}

Em 1875 começou a ser construída a Ferrovia da Companhia Paulista de Estrada de Ferro, cujo percurso inicial ligava a cidade de Campinas até o distrito de Cordeiro, pertencente à Vila de Limeira. A ferrovia representava uma mudança significativa e novos rumos para as cidades por ela servidas, pois, se organizava toda uma estrutura urbana para receber o leito ferroviário e sua estação. A ferrovia propiciava o crescimento do comércio e do número de habitações, além de facilitar o deslocamento de pessoas e mercadorias. Pelo trem, chegava o imigrante para trabalhar em lavouras agrícolas na substituição da mão de obra escrava, chegavam serviços e encomendas, e chegavam também autoridades, como o bispo diocesano em suas visitas pastorais, além do Imperador e sua corte.

16 Nota se neste período um crescimento de grandes propriedades de café nas regiões compreendidas entre: Campinas, São Carlos e Ribeirão Preto. 


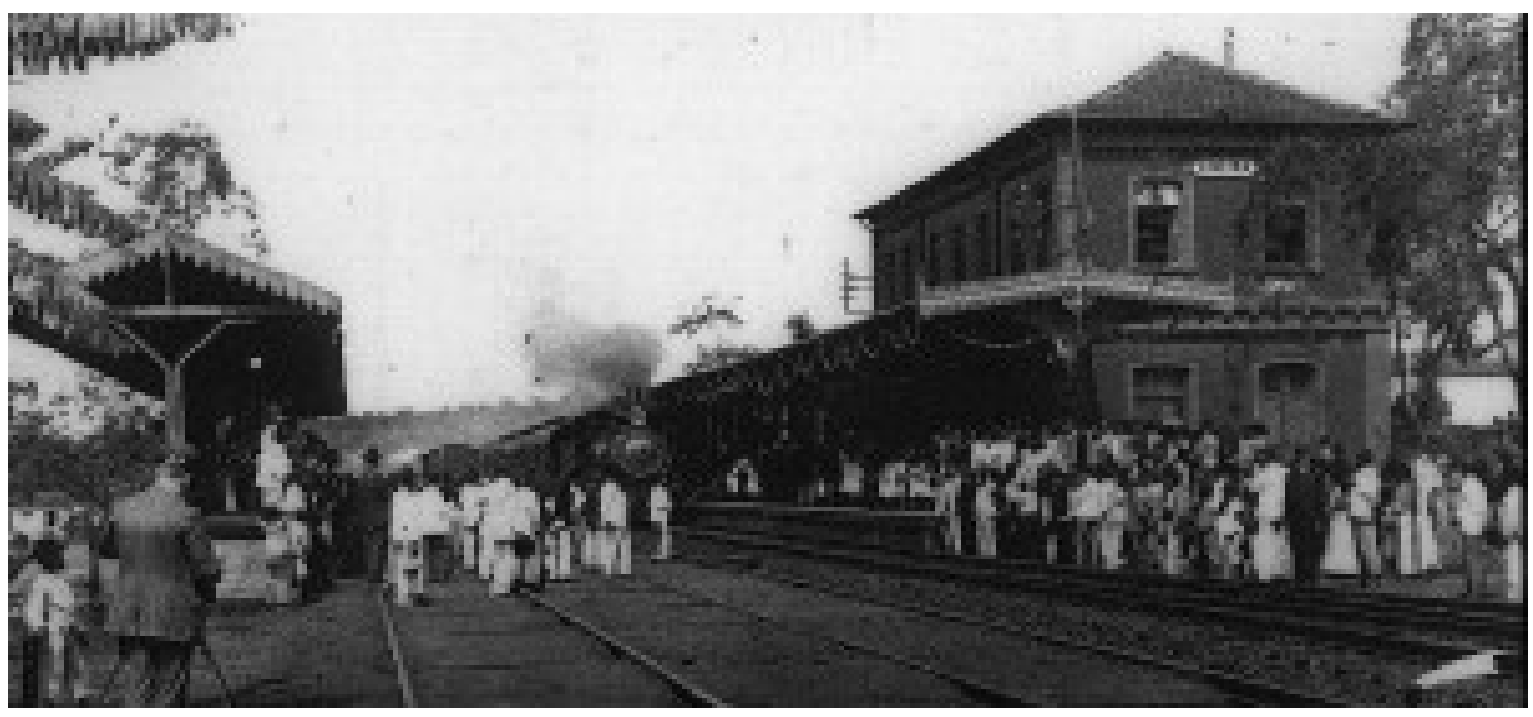

Figura 08: Estação Ferroviária de Limeira na época de sua inauguração em 1876. Fonte: Estações Ferroviárias do Brasil.

A estação de Limeira foi inaugurada em 1876 e, devido ao montante produzido pela região, a Companhia Paulista decidiu prolongar o ramal de Cordeiro até Belém do Descalvado, cortando desta forma quase todo o território do que viria a se tornar a Diocese de Limeira. Segundo relatórios da própria companhia em 1875, o projeto do prolongamento atingiria a povoação de Santa Cruz da Conceição (CORRÊA, 2005, p.29). Porém, mudanças realizadas de última hora, fizeram com que a linha não fosse executada conforme o projeto original: em vez de alcançar Santa Cruz da Conceição, o percurso foi desviado para as terras da fazenda de Manoel Joaquim de Oliveira Leme, onde hoje se encontra a cidade de Leme, e para as terras de Francisco Antônio de Souza Queiroz, o Barão de Souza Queiroz.

Dificuldades topográficas e o aumento de 8 quilômetros no trajeto imaginado, são os motivos com que os engenheiros e técnicos justificaram a mudança da via férrea. No entanto, tal mudança causou grande descontentamento na população de Santa Cruz e entre os viajantes e tropeiros, pois a estação de Leme não possuía infraestrutura necessária para vendas e pouso, além da ausência de uma igreja para os serviços religiosos (CORRÊA, 2005, p.30).

Apesar dos protestos, a mudança do leito ferroviário foi confirmada pela Companhia, e em 1877 foi finalizado o trecho da ferrovia até a estação do Leme. A passagem da ferrovia e a implantação de uma estação que poderia ter beneficiado toda uma região acabou por beneficiar os grandes produtores rurais que detinham de influência junto à Companhia. A propriedade do Barão de Souza Queiroz, que era senador do Império e um dos acionistas da Companhia Paulista, recebeu também, em 1896, uma estação, denominada Souza Queiroz, onde se formou um pequeno núcleo urbano posteriormente elevado a distrito (DE BEM, 1998, p.72). No entanto, o núcleo de Santa Cruz, que era majoritariamente composto por pequenas propriedades rurais e não possuía nenhum morador de grande relevância política, 
acabou ficando sem a ferrovia.

Tal mudança implicou em problemas definitivos no desenvolvimento econômico e social de Santa Cruz da Conceição, cujo contingente populacional, como já apontado, começou a declinar logo nas primeiras décadas do século XX, diferente das cidades que receberam a ferrovia e tiveram suas estações construídas. Em 1921, a cidade já experimentava um esvaziamento e abandono, cuja impressão fora relatada pelo pároco no livro tombo da paróquia:

Resumindo minha impressão sobre o anno de 1921, devo dizer que o lugar de Santa Cruz da Conceição parece-me estar em plena decadência, devido à Estrada de Ferro que passa por Leme e para lá attrahiu todo o movimento. Aqui não tem mais comércio, nem indústria, nem obras sociais, as ruas estão invadidas pelo capim, desde mais de dez anos, não se edificou uma casa, pelo contrário, o número de casa abandonadas não é pequeno, nesse ano mudaram para outros lugares cerca de 10 famílias. A povoação consta apenas de quinhentos para seiscentos moradores, dos quais só nove pequenos comerciantes. O Governo Estadual deu doze contos de reis para começar um grupo escolar, mas depois de acabado os alicerces, há seis meses, tudo parou. Uma companhia de luz elétrica do Rio Claro, tratou com a Câmara Municipal, a iluminação da cidade com prazo de 3 mezes, a datar de novembro de 1921. Alguns dizem que a Companhia cometeu um erro, porque a maior parte dos moradores preferem continuar a usar o lampiãozinho de querosene do que gastar algum dinheiro para pôr a luz elétrica em casa. De facto, a luz elétrica virá iluminar aqui um cemitério abandonando, tal o aspecto da cidade [..] (TOMBO II. NSC. p.27). [grifo nosso]

O trem e o serviço de exportação da produção agrícola eram bem vistos pelos moradores e administradores municipais, pois formavam pequenas comunidades ao redor das estações ferroviárias que colaboravam no desenvolvimento local. Tais aglomerações surgiram para suprir a necessidade de trabalhadores na carga e descarga dos trens, na manutenção dos trilhos e da estação, além de pequenos comerciantes para atender aos viajantes. A linha de expansão da Companhia Paulista, que partia da estação do Cordeiro até Belém do Descalvado, colaborou de modo efetivo no desenvolvimento das cidades que se encontravam ao norte de Limeira, como Araras, Leme, Pirassununga, Porto Ferreira e Descalvado.

\section{O CRESCIMENTO POPULACIONAL - IMIGRANTES E OS NÚCLEOS COLONIAIS}

A consolidação de novos territórios voltados a novas atividades econômicas será o embrião para o surgimento de novas cidades, cuja dinâmica será marcada por múltiplos fatores incidentes. A vinda de imigrantes para trabalhar nas lavouras de café e substituir a mão de obra escrava, subsidiada por políticas públicas do Governo, irá possibilitar novas aglomerações e formações urbanas, com configurações diversificadas das experimentadas até então. Destaca-se nesse processo a formação dos núcleos coloniais e o surgimento de colônias dentro das fazendas cafeeiras. 
A ocupação territorial era de grande interesse por parte do governo estadual, tanto para o fornecimento de mão de obra para os produtores de café, quanto para a produção de alimentos em pequena escala para o abastecimento das cidades, uma vez que as grandes propriedades estavam produzindo para a exportação. As colônias tinham ainda como objetivo criar povoamentos no sertão do pais e a valorização de terras improdutivas. Os imigrantes eram alocados na Hospedaria dos Imigrantes na cidade de São Paulo, até serem destinados ao seu local de destino: fazendas, colônias ou núcleos coloniais (FERREIRA, 2011, p.45).

Nas fazendas, os imigrantes iriam compor parte do corpo de funcionários e iriam morar sob acordo na propriedade. Haviam duas possibilidades: as colônias que se caracterizavam por grupos que moravam nas propriedades dos cafeicultores, e os núcleos coloniais, que eram conjuntos de pequenos sítios sob tutela do governo, com lotes entre 10 e 40 hectares. 0 conjunto dos núcleos coloniais eram administrados pelo governo até que todos os colonos quitassem os valores devidos pelos lotes, quando eram então emancipados. De todo modo, os núcleos coloniais agradavam a todas as partes envolvidas: os colonos, por terem sua propriedade privada e nela cultivarem sua subsistência, e o governo e produtores, pela mão de obra barata e estável, e especialmente pelo controle do tamanho das propriedades, que impossibilitava os colonos de competir com os grandes latifúndios ${ }^{17}$.

Os núcleos coloniais foram implantados pelo governo numa estratégia de desenvolvimento econômico e social. A escolha dos locais para a implantação de tais empreendimentos era feita de acordo com as propriedades ao redor, que garantiriam emprego para os profissionais ao longo do ano. A lei Orgânica dos Núcleos Coloniais (Decreto Lei no 272 de 10/12/1984) permitia que os colonos trabalhassem fora de seu lote por até 15 dias mensais (ATIQUE, 2004, p.45).

\section{A FREGUESIA DE NOSSA SENHORA DO PATROCÍNIO DAS ARARAS}

Os primórdios da atual cidade de Araras vinculam-se à construção de uma capela dedicada à Nossa Senhora do Patrocínio, nas terras da sesmaria de Bento de Lacerda Guimarães (Barão de Araras), e José de Lacerda Guimarães (Barão de Arary) em 15 de agosto de 1862. Em 1865, devido à presença de considerável número de casas ao redor da capela, os proprietários do local onde se encontrava a ermida oficializam a doação das terras ao patrimônio de Nossa Senhora do Patrocínio, cuja freguesia foi criada 4 anos depois, em 12 de junho de 1869, sendo anexada ao termo da vila de Limeira. A elevação a vila aconteceu rapidamente, apenas

17 Para saber mais sobre o processo de constituição e os núcleos coloniais, ver: GADELHA, Regina Maria D’Aquino Fonseca. Os núcleos coloniais e o processo de acumulação cafeeira (1850-1920). Contribuição ao estudo da colonização em São Paulo. São Paulo: 1982. Tese (Doutorado) - Faculdade de Filosofia, Letras e Ciências Humanas da Universidade de São Paulo. 
dois anos depois da criação da freguesia, porém a instalação só se efetivou em 7 de janeiro de 1873. Araras teve sua estação da Companhia Paulista inaugurada em 1877 e foi elevada a cidade em 2 de abril de 1879.

\section{PORTO FERREIRA - O ENCONTRO DO TREM COM O RIO.}

Porto Ferreira surge a partir de "três acontecimentos básicos e inteiramente circunstanciais: a balsa, o trem de ferro e a navegação fluvial" (OLIVEIRA, 2005, p.38). Até meados da década de 1850, a região localizada na freguesia de Nossa Senhora do Belém do Descalvado e próxima ao rio Mogi Guaçu era pouco habitada, e servia como entroncamento de estradas que partiam da província de São Paulo desejando alcançar a região das Minas Gerais.

No entanto, a travessia do rio de um lado para o outro era um desafio para os viajantes e exploradores que desejavam adentrar o sertão paulista. O nome de Porto Ferreira tem sua origem vinculada à atividade desempenhada pelo balseiro João Inácio Ferreira para suprir tal necessidade, realizando a travessia do rio, numa região conhecida como Boa Vista, confluência de várias estradas com o Mogi Guaçu (OLIVEIRA, 2005, p.25).

Em 1860, boa parte das terras onde se localizava o ponto do balseiro João Ferreira, que eram de propriedade do Barão de Souza Queiroz, foram compradas por Joaquim Procópio de Araújo, que proibiu o tráfego de pessoas e viajantes por ali. Em consequência disto, as tropas que integravam o sistema de transporte entre o Litoral Paulista e Uberaba (atual Triângulo Mineiro) não conseguiam mais acessar o serviço de travessia do rio, ocasionando assim a mudança do balseiro para uma região mais abaixo do Mogi Guaçu, junto à foz do rio Corrente, também conhecida como Laranja Azeda (OLIVEIRA, 2005, p.25).

João Ferreira tratou rapidamente de comprar as terras onde havia se instalado para não correr o risco de ter que se mudar novamente. Construiu residência e fixou o serviço para a travessia de pessoas, mercadorias e animais, alterando também a direção das antigas estradas de escoamento e desbravadores. O local ficou conhecido como Porto do João Ferreira, cuja denominação consta também em mapas oficias da província. Com o passar dos anos, a construção de uma ponte de madeira sobre o rio, em 1879, fez com que o serviço de balsa fosse paulatinamente descontinuado (OLIVEIRA, 2005, p.26). 


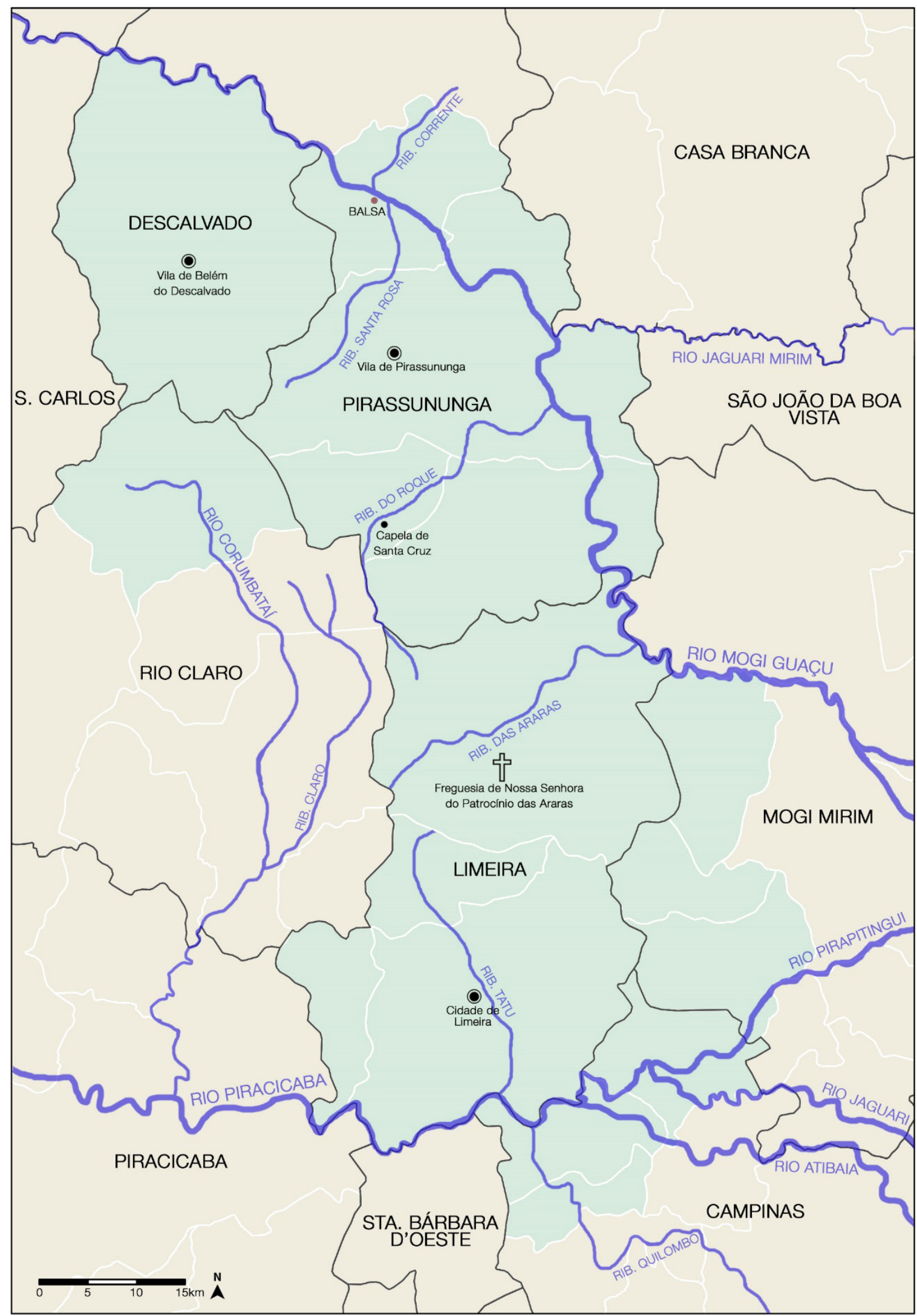

Figura 09: Mapa da Região em 1870. Com o surgimento de novas vilas, o termo da Vila de Limeira foi diminuindo. Nota-se a presença do ponto do balseiro ao norte, próximo ao Ribeirão Corrente no termo da Vila de Pirassununga. Fonte: Elaborado pelo autor. Baseado em: Fundação Seade (2000) e CESAD FAU. 


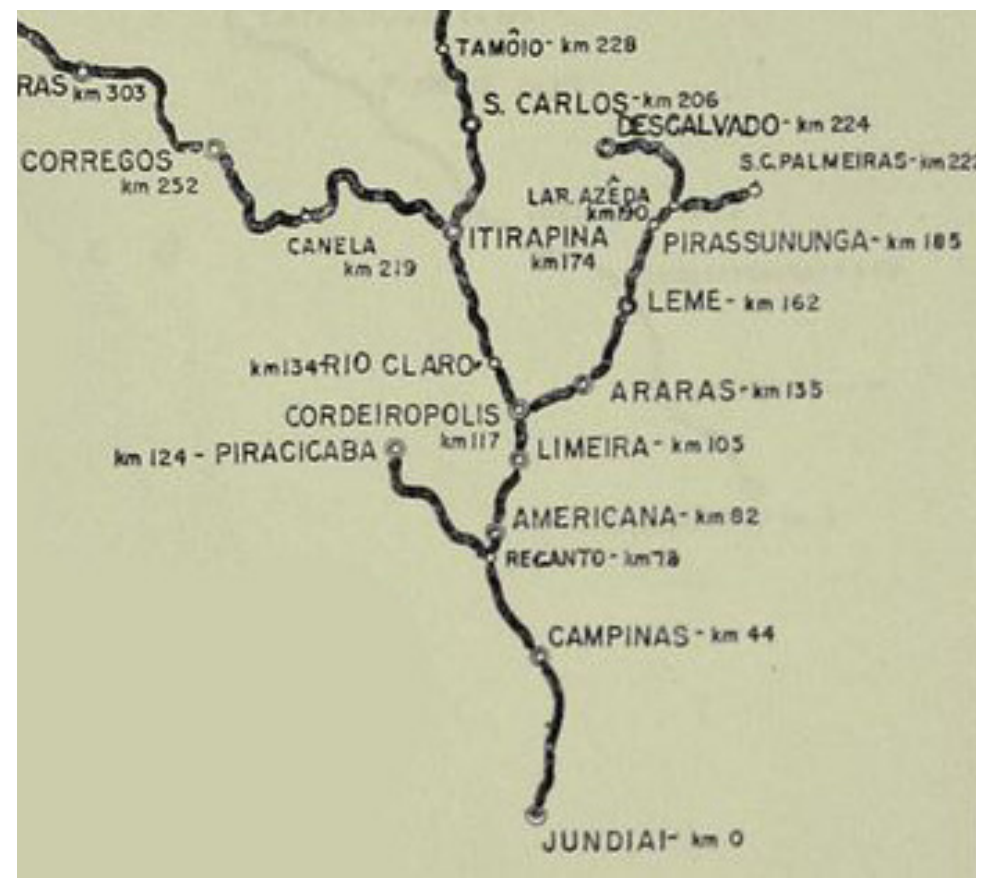

Com a expansão das propriedades agrícolas, principalmente cafeicultoras, na região central do estado, as ferrovias continuaram a adentrar o sertão paulista, visando facilitar o escoamento da produção. A Companhia Paulista, cujo ramal partindo de Cordeiro estava sendo construído, alcançou a região, praticamente erma e desprovida, do Porto do João Ferreira, em 15 de janeiro de 1880 (ARNONI, 2020. p.09).

Figura 10: Mapa da Linha da Companhia Paulista, com destaque para o ramal que parte de Cordeirópolis para a região de Porto Ferreira, identificada como Laranja Azeda. Fonte: Ferrovias do Brasil.

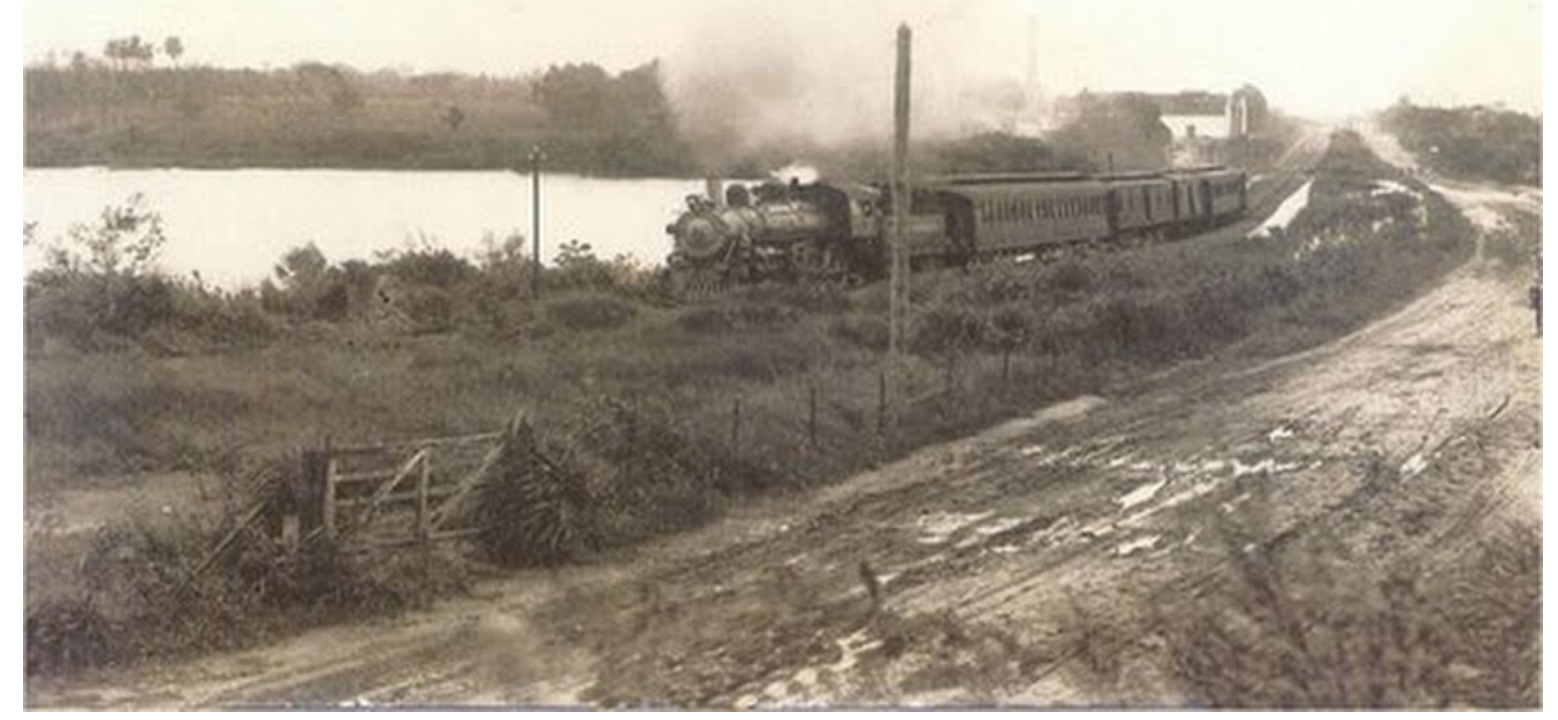

Figura 11: Trem chegando a região do Porto Ferreira tendo o rio Mogi Guaçu ao fundo. Fonte: Acervo do Museu Histórico e Pedagógico Flávio da Silva Oliveira.

A passagem da ferrovia por fazendas, freguesias e vilas, e sua chegada até o rio Mogi Guaçu significava um grande salto de desenvolvimento para a região. Porém, o objetivo da empresa era alcançar a região de Ribeirão Preto e Franca, grandes produtoras de café. 
Enquanto aguardava a autorização do Governo Provincial para a construção de uma ponte sobre o rio Mogi Guaçu para expandir seus trilhos do outro lado da margem, a Companhia Paulista tratou de construir um ramal até a região de Belém do Descalvado, inaugurado em 7 de novembro de 1881.

Em 1883, o Governo Provincial determinou que as terras além do rio Mogi Guaçu deveriam ser exploradas pela Companhia Mogiana de Trens, cujos trilhos já serviam a região de Casa Branca. A decisão do Governo Provincial atrapalhou os planos da Companhia Paulista, que desejava estabelecer um grande eixo de escoamento da produção de café.

No entanto, como a Companhia Paulista já havia implantado seus trilhos até a região do rio Mogi Guaçu, num ato visionário e empreendedor, a empresa decidiu estabelecer a navegação fluvial de cargas e pessoas naquele rio, atingindo de outra maneira a região cafeicultora e instituindo a ligação da região do Pontal, onde o rio Mogi Guaçu desemboca no Rio Pardo, com a ferrovia, e assim, com o porto de Santos.

\section{A NAVEGAÇÃO DO RIO MOGI GUAÇU}

A ideia de navegar e utilizar os rios como meio de transportes não era algo inédito, porém era algo dificultoso. Os rios, que já haviam sido desbravados por bandeirantes e aventureiros, chamavam a atenção por cortarem todo o território paulista, nos mais variados sentidos e direções. As dificuldades vivenciadas se davam pela topografia e pela presença de corredeiras e quedas d'águas em determinados trechos percorridos pelos cursos d'água, além de que muitos deles apresentavam instabilidade quanto ao volume de água, dependendo da época do ano.

Vários planos foram traçados pelo Governo Provincial no intuito de utilizar os rios como meio de transporte e de conquista do território. No entanto, nenhum plano oficial havia se concretizado. Aventureiros e desbravadores se arriscavam ilegalmente a avançar ao longo do percurso dos rios, estabelecendo desta forma um princípio de comércio fluvial. Como aponta Domingues Neto (2009), a navegação fluvial era tida como uma forma de progresso e sua regulamentação era desejada pelo Governo Imperial:

Para o estado, portanto, a regulamentação da navegação se tornava imperativa, pois Ihe proporcionaria, mediante a atuação da iniciativa privada, uma ampliação das vias de comunicações necessárias à manutenção da integridade de imenso território, no caso de dissensões internas ou de ameaça estrangeira às suas fronteiras (DOMINGUES NETO, 2009, p.29).

No que se refere ao rio Mogi Guaçu, em 1858, o governo emitiu autorização para explorações acerca de sua navegabilidade, que, não obstante, não foram executadas pela escassez de recursos materiais. Todavia, o engenheiro civil Fernandes Vaz de Mello, interessado nas 
possibilidades que o rio poderia oferecer neste sentido, sai em expedição particular para verificar as condições ao longo de seu percurso. No memorial descritivo apresentado acerca das conclusões obtidas, o engenheiro aponta as possibilidades e custos para a construção de portos, características das comunidades ribeirinhas e a presença de uma movimentada atividade mercantil ao longo do rio. Destaca, ainda, a "importância daquele roteiro para o comércio entre a província de São Paulo e da Corte com Minas Gerais, Goiás e Mato Grosso" (DOMINGUES NETO, 2009, p.30).

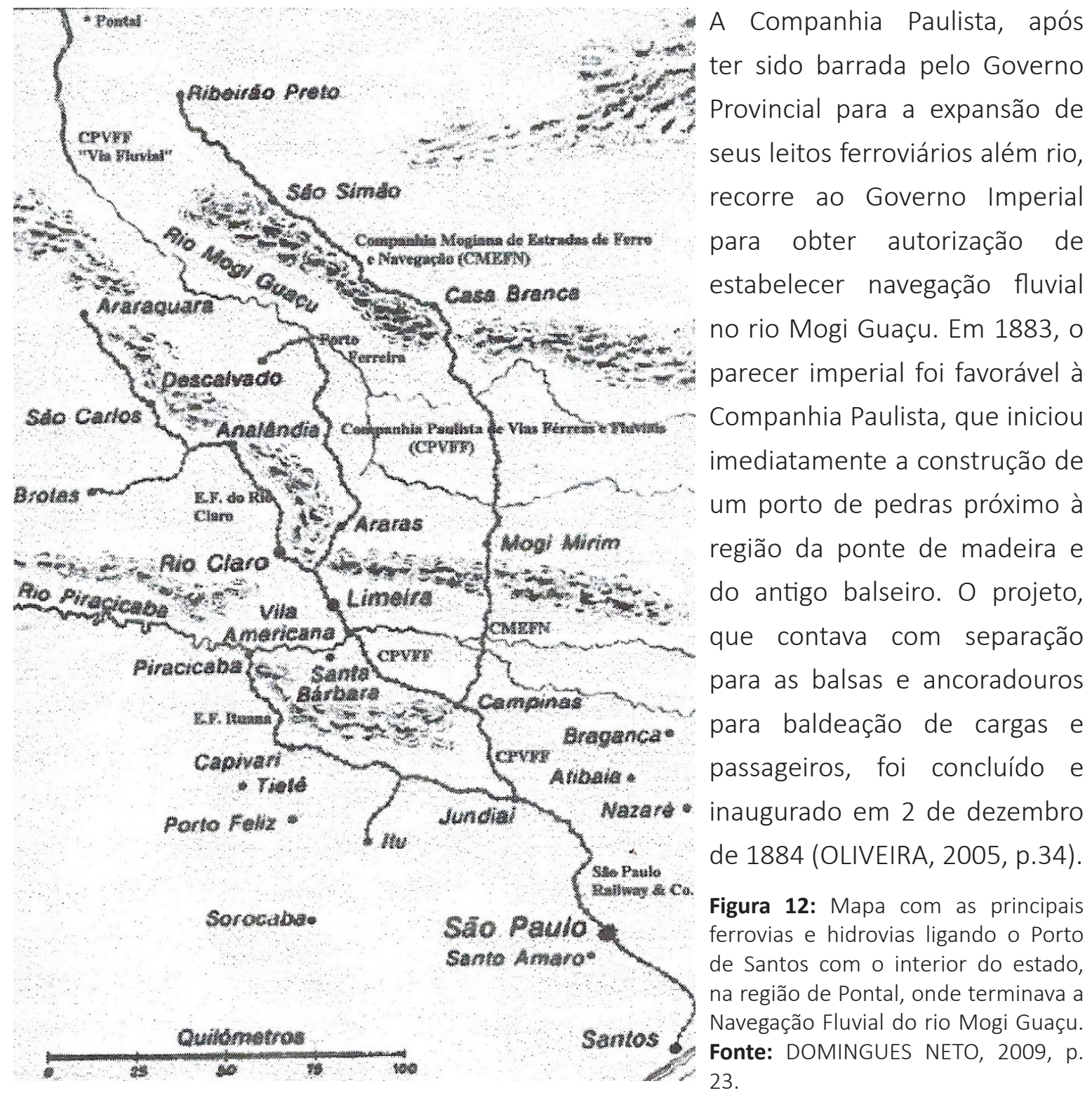




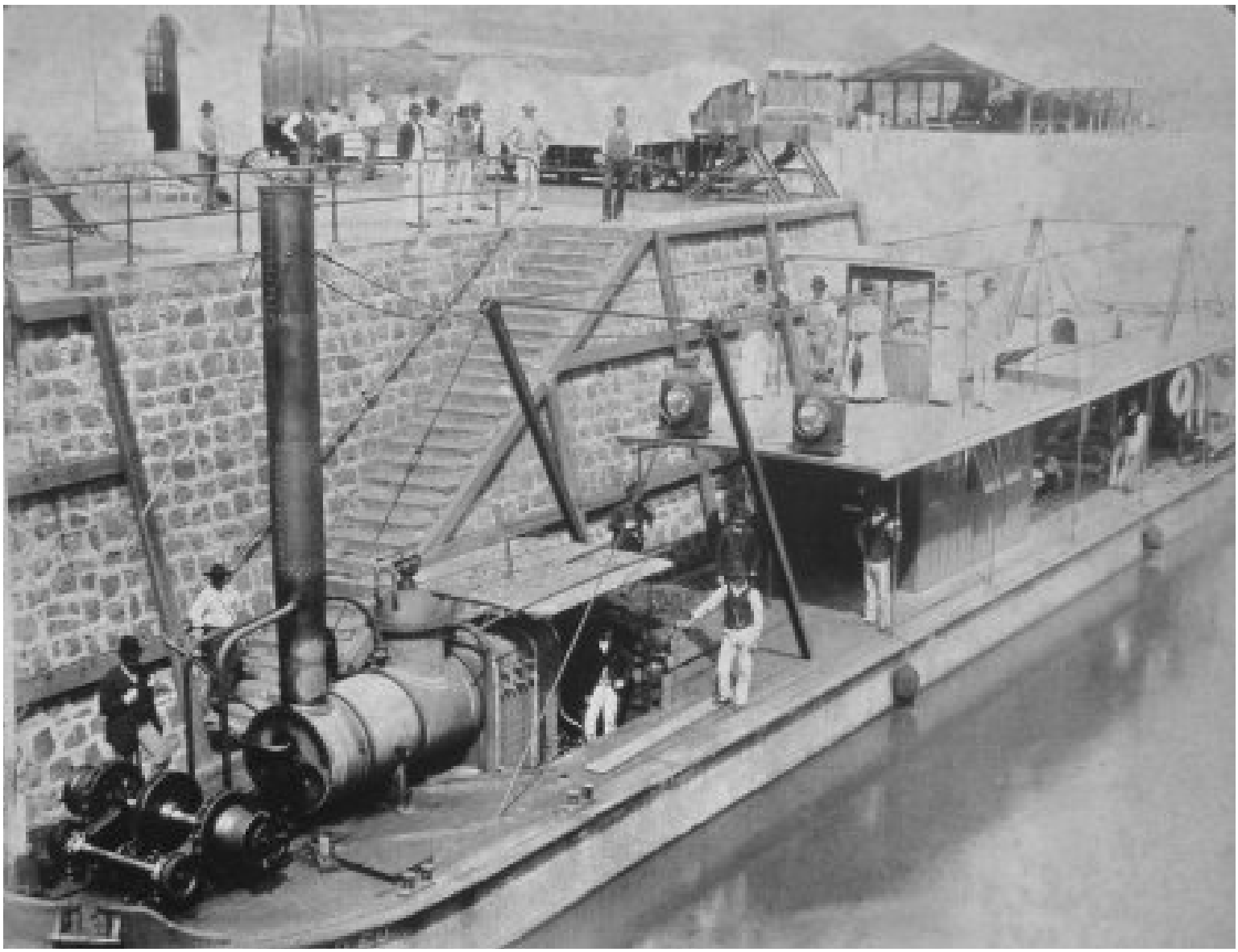

Figura 13: Lancha a vapor atracada no ancoradouro em Porto Ferreira. Fonte: DOMINGUES NETO, 2009, p. 89.

\section{A CAPELA DE SÃO SEBASTIÃO DO PORTO FERREIRA}

A navegação fluvial, cujo percurso total de 205 quilômetros foi autorizado a partir de 10 de janeiro de 1887, acarretou em significativas mudanças na região. Com a ferrovia, o porto e a construção de docas para manutenção dos barcos, foi se criando um pequeno aglomerado de pessoas que afluíam à região em busca de emprego (ARNONI, 2020, p.09). Além disso, as propriedades de café da região já contavam com um número grande de colonos e imigrantes. Segundo publicações em jornais da época: "esta pequena e florescente povoação está situada nos terrenos da Companhia Paulista e dá obediência ao município de Belém do Descalvado" (OLIVEIRA, 2005, p.50).

Com o crescimento e o surgimento de um núcleo urbano, a primeira providência tomada pela Câmara de Pirassununga em 1884 foi "sahir e designar o lugar mais apropriado para nelle ser edificada uma capela sob invocação de São Sebastião do Porto Ferreira" (MOTTA JÚNIOR, 1884, p.49). É interessante notar que, devido às grandes extensões territoriais que possuíam as freguesias e vilas na época, não ficavam claras quais eram as áreas de atuação e limites de cada câmara, pois o ato inicial de demarcação do local da capela foi feito pela câmara da Vila de Pirassununga, dentro do termo da então Vila de Belém do Descalvado. 
Enquanto não se realizava a construção da capela, os serviços religiosos eram ofertados esporadicamente em oratórios particulares pelo vigário de Belém do Descalvado. Em 06 de setembro de 1884, foi feita a solicitação de autorização para a edificação da dita capela na região do Porto Ferreira, termo da Vila de Belém do Descalvado. Com parecer positivo, a construção iniciou-se em 1886 e teve entre seus benfeitores a Companhia Paulista, que pagou todo o madeiramento, telhado e traves de ferro, e a Câmara Municipal de Belém do Descalvado, que doou quatro contos de réis (OLIVEIRA, 2005, p.51).

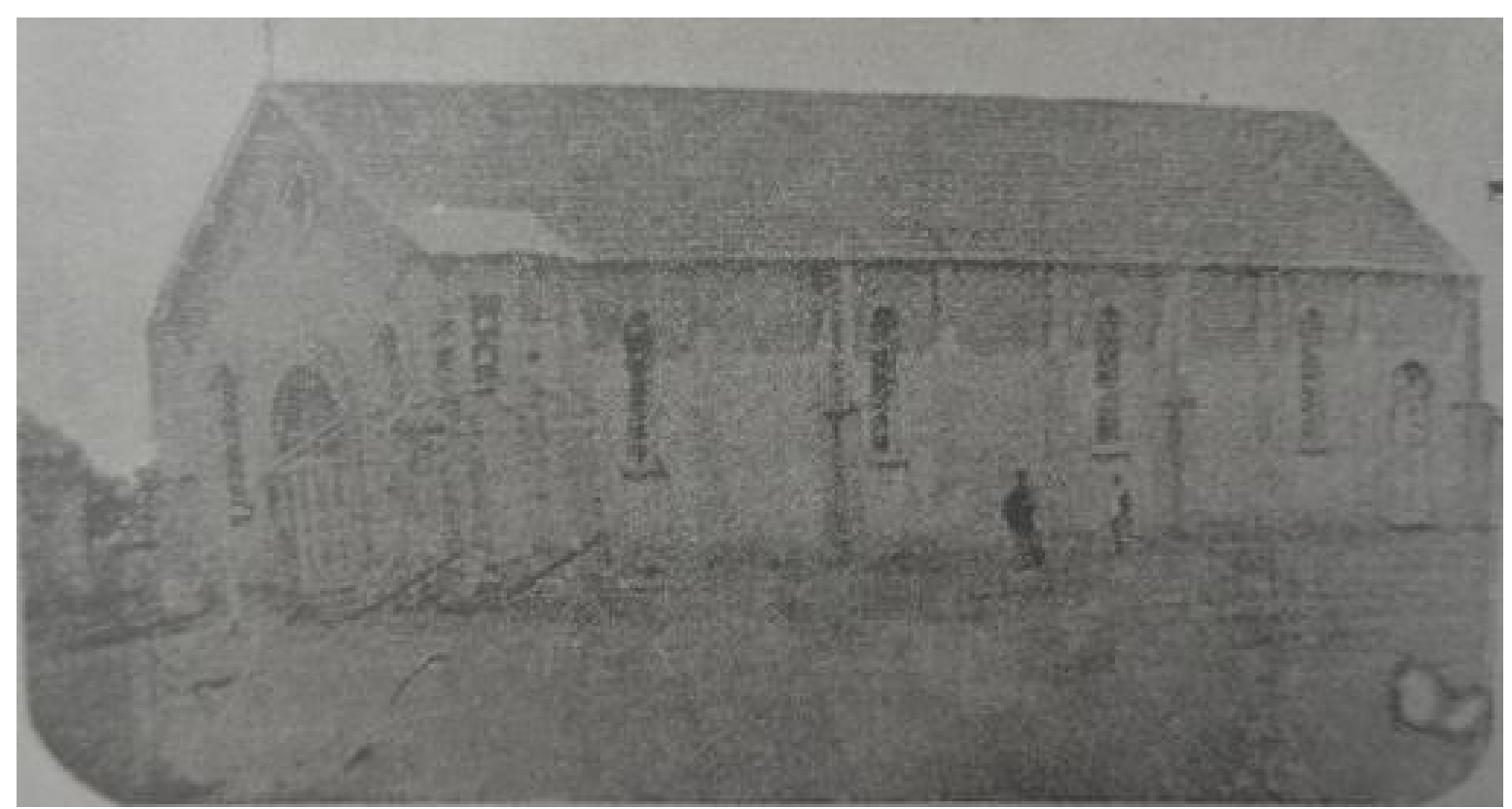

Figura 14: Capela de São Sebastião do Porto Ferreira Fonte: OLIVEIRA, 2005, p. 50.

Apenas dois anos após a sua inauguração, em 1886, a capela foi elevada a Freguesia de São Sebastião do Porto Ferreira por lei provincial de 09 de fevereiro de 1888, continuando anexada ao termo da Vila de Belém do Descalvado. Para isso, seguindo os protocolos vigentes na época, foi oficializada a doação de terras para compor o patrimônio de São Sebastião. Ao contrário do que acontecia na maior parte das cidades, as terras não foram doadas por uma única pessoa, mas por quatro:

Assim é que, refletindo os anseios da população, Andrelino Augusto do Amaral e Francisco de Camargo Neves, por escritura lavrada no cartório de Descalvado, no dia 10 de dezembro de 1889, doaram à então Capela de São Sebastião respectivamente, quatro e seis alqueires de terra, que faziam parte da Fazenda da Grama e deviam ser demarcadas "nas imediações da Igreja". Alguns dias depois, (25-12-89), no mesmo cartório, Vicente José de Araújo, também residente em Descalvado, doou mais quatro alqueires, igualmente localizados na Fazenda da Grama. Mais tarde, a 5 de outubro de 1891, conforme consta no mesmo cartório, a viúva Dona Balbina Mendes de Oliveira fez nova doação ao Patrimônio, correspondente a cinco alqueires e cuja área deve ser demarcada junto as demais glebas doadas (OLIVEIRA, 2005, p.58). 
Desta forma, o patrimônio de São Sebastião totalizou 19 alqueires de terra, tornando se proprietário de quase 460 metros quadrados nas imediações da igreja, exceto pelas terras onde estava a Companhia Paulista. A proximidade das terras do patrimônio com as da Companhia acarretou inúmeros problemas com posseiros para a Fábrica da Matriz ${ }^{18}$, dado que as pessoas buscavam se assentar próximo ao porto e à ferrovia (ARNONI, 2020, p.12). Formalizações posteriores referentes as terras do patrimônio revelaram que apesar das escrituras darem a entender que as terras formavam um todo continuo, isso não aconteceu, sendo a igreja proprietária das terras onde se encontrava a capela e arredores e alguns terrenos mais distantes e desconectados do núcleo central.

A presença do pároco e a constituição dos serviços civis que a freguesia acarretava foram indutores do contínuo crescimento de Porto Ferreira. Com o advento da República, a freguesia, já transformada em Distrito de Paz foi anexada ao município de Pirassununga, do qual se emancipou em 29 de julho de 1896.

\section{OUTRAS CIDADES DO FINAL DO SÉCULO XIX}

DO SALTO GRANDE À VILA AMERICANA

A ocupação do território que hoje configura a cidade de Americana tem início no começo do século XIX com a concessão de sesmarias. Duas delas são notáveis: a sesmaria onde se encontra o engenho do Salto Grande, próximo à formação do Rio Piracicaba, na junção dos rios Atibaia e Jaguari, e a região do rio Quilombo, onde se formou o primeiro núcleo urbano após o loteamento realizado por Ignácio Correa Pacheco. A chegada da ferrovia em 1875, com o nome de Estação Santa Barbara, possibilitou o crescimento local e o surgimento da Capela de Santo Antônio. A chegada maciça de imigrantes americanos nos últimos anos do século XIX fez com que o local ficasse conhecido como povoação de Santo Antônio da Vila ${ }^{19}$ Americana. Em 30 de julho de 1904, foi elevado como Distrito de Paz da Vila Americana, pertencente ao município de Campinas, de quem se desmembrou em 12 de novembro de 1924.

\section{DE SÃo LÁZARO A SÃO MANOEL - A CIDADE DE LEME}

Como vimos, Leme surgiu a partir da estação da Companhia Paulista, inaugurada em 1877, nas terras de Manoel Joaquim de Oliveira Leme. Com a chegada da estação, um pequeno povoado se formou e foi construída uma pequena capela dedicada a São Lázaro. Com a

18 Questões referentes a vida da paróquia e a fábrica da Matriz serão tratadas mais adiante, no capitulo 2 . 19 Aqui o termo vila é empregado como conhecemos hoje em dia, no sentido de bairro, não como organismo de divisão e organização territorial. 
morte de Manoel Leme, seus herdeiros fizeram a doação de dois alqueires de terra para a constituição do patrimônio, que, em homenagem ao pai, passou a denominar-se São Manoel, em vez de São Lázaro. Em 1889 foi criada a Freguesia de São Manoel do Leme anexada ao termo da Vila de Pirassununga, da qual tornou-se posteriormente distrito, até sua emancipação em 29 de agosto de 1895.

\section{O BAIRRO DO CORDEIRO E A CIDADE DE CORDEIRÓPOLIS.}

Cordeirópolis localiza-se na região de Limeira, a partir de um aglomerado urbano que surgiu nas imediações da antiga Fazenda Cordeiro e da implantação de um núcleo colonial na região do Cascalho, ocupado principalmente por imigrantes italianos. Em 1876, a chegada da ferrovia da Companhia Paulista possibilitou um rápido crescimento da região. Em 1885, Manoel Barbosa Guimaraes loteou uma área próxima à estação e construiu uma Capela dedicada a Santo Antônio. A localidade ficou conhecida como Capela de Santo Antônio do Cordeiro, e foi elevada a Distrito de Paz em 7 de agosto de 1899. Em 1943, após plebiscito entre os moradores, o nome do distrito foi mudado para Cordeirópolis, um ano antes de sua emancipação, que aconteceu em 30 de novembro 1944.

\section{SANTA ANA, ANÁPOLIS, ENFIM: ANALÂNDIA}

Os primórdios da cidade de Analândia estão ligados à doação 20 alqueires de sua Fazenda Santa Maria da Glória, na sesmaria do Cuscuzeiro, que Manoel Vicente Lisboa fez, em 23 de novembro de 1887, para construção de uma capela sob invocação de Santa Ana e a formação de um novo povoado. O local, onde já tinha sido construída uma estação de trem do ramal da Companhia Rio Clarense, que ligava Rio Claro a São Carlos, em 1884, posteriormente comprada pela Companhia Paulista, foi elevada a Distrito de Paz em 17 de dezembro de 1890 com o nome de Anápolis, em homenagem à padroeira local. Foi desmembrada de Rio Claro em 21 de junho de 1897, quando se deu sua elevação a cidade. Em 1944, a cidade de Anápolis teve seu nome mudado para Analândia devido à existência de outra cidade com o mesmo nome, no estado de Goiás.

\section{A SESMARIA DO MORRO AZUL E O NASCIMENTO DE IRACEMÁPOLIS}

O município de Iracemápolis, cujo território e espaço urbano foram por muito tempo pertencentes a Limeira, possuem o mesmo vínculo inicial de ocupação territorial. A região da sesmaria do Morro Azul foi a célula inicial para a formação do bairro que deu origem à cidade, cujos engenhos, seus proprietários e produções agrícolas estão ligados também à história de Limeira, como é o caso do Engenho Ibicaba, propriedade do Senador Vergueiro. Além disso, a região contava com inúmeras fazendas produtoras de cana-de-açúcar e milho, entre elas as fazendas Paraguassu, Paramirim e a Fazenda Morro Azul, propriedade do 
Brigadeiro Manoel Rodrigues Jordão, na qual futuramente, iria se assentar o povoado que daria origem à futura cidade de Iracemápolis (ZANARDO, 2008, p.13).

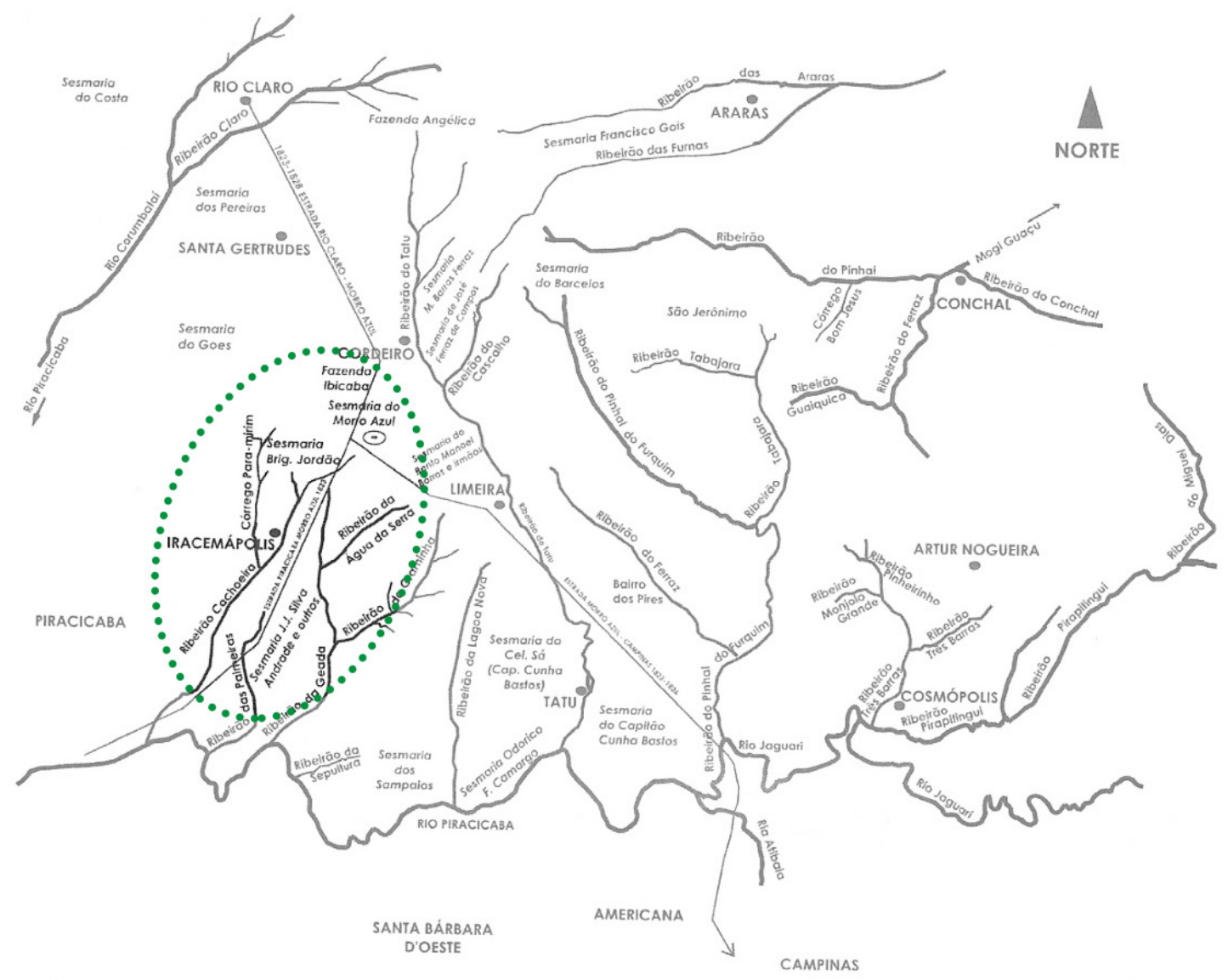

Figura 15: Mapa das sesmarias da região. Em destaque: região onde hoje se encontra a cidade de Iracemápolis e a sesmaria do Morro Azul. Fonte: BUSCH, 200, p.43. Elaborado pelo autor.

Devido à expressiva produção agrícola dos engenhos da região do Morro Azul, havia uma estrada ligando a região à Vila de Constituição, que por sua vez chegava até a Vila de Itu, ligando-se assim com São Paulo, antes mesmo da abertura da Estrada Geral em $1823^{20}$, ligando a região do Morro Azul à Vila de São Carlos, para facilitar o escoamento da produção agrícola.

Além dos grandes e pequenos proprietários rurais, negros libertos também começaram um processo de ocupação na encosta do Morro Azul, na região da Fazenda Iracema - fruto do desmembramento da Fazenda Morro Azul, propriedade do Brigadeiro Silvério Jordão, às margens do Ribeirão Cachoeirinha (ZANARDO,2008, p.64).

20 Trata-se da Estrada Geral aberta em 1823 ligando a região do Morro Azul a Vila de São Carlos (Campinas), como já apontado anteriormente. 


\section{A ORIGEM DO POVOADO DE SANTA CRUZ DA BOA VISTA}

As primeiras notícias sobre o povoado que deram origem ao bairro de Santa Cruz da Boa Vista remontam ao final do século XIX, quando em 1886, o fazendeiro José Emídio ${ }^{21}$ doou dois alqueires de terra para a construção de uma capela em homenagem a Santa Cruz. Com a promulgação da Lei Áurea em 1888, a região que já era conhecida e ocupada por negros libertos, recebeu um número maior de negros que buscavam um ponto para se estabelecer. A capela ficou pronta e foi inaugurada em 1891, com um pequeno contingente populacional ao seu redor, de casas simples de barro e madeira (ZANARDO, 2008, p.53).

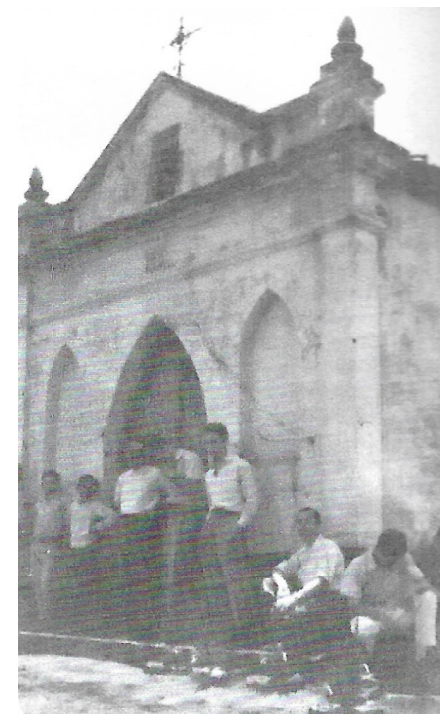

Figura 16: Capela de Santa

Cruz da Boa Vista em 1924 Fonte: Acervo da Paróquiapara o manejo da cana (ZANARDO, 2008, p.21). Com os negócios Jesus Crucificado. prósperos, em 1932, a família adquire a Fazenda Boa Vista, grande propriedade de terra com expressiva produção agrícola, que passou então a produzir também açúcar. Em 1937, os Ometto compram a Fazenda Iracema22, transformando-a numa destilaria de álcool. Assim, nascia a Usina Iracema, importante grupo fabril e protagonista no desenvolvimento de Iracemápolis e nas ações referentes a sua Igreja Matriz.

Em 29 de outubro 1923 o povoado foi elevado à categoria de Distrito de Paz da cidade de Limeira pela Lei no 1931, recebendo o nome de Distrito de Iracemápolis, em referência às terras nas quais havia nascido o povoado. A emancipação político-administrativa aconteceu em 30 de dezembro de 1953, pela Lei no 2456, quando ocorreu o desmembramento de todo

21 Em todas as fontes pesquisadas aparece este nome como o doador oficial das terras, no entanto, este não é um nome encontrado entre os proprietários da época, e em nenhum lugar há menção do seu sobrenome.

22 Atualmente a usina Iracema pertence ao grupo São Martinho, ainda de propriedade da Família Ometto. 
o seu território do município de Limeira.

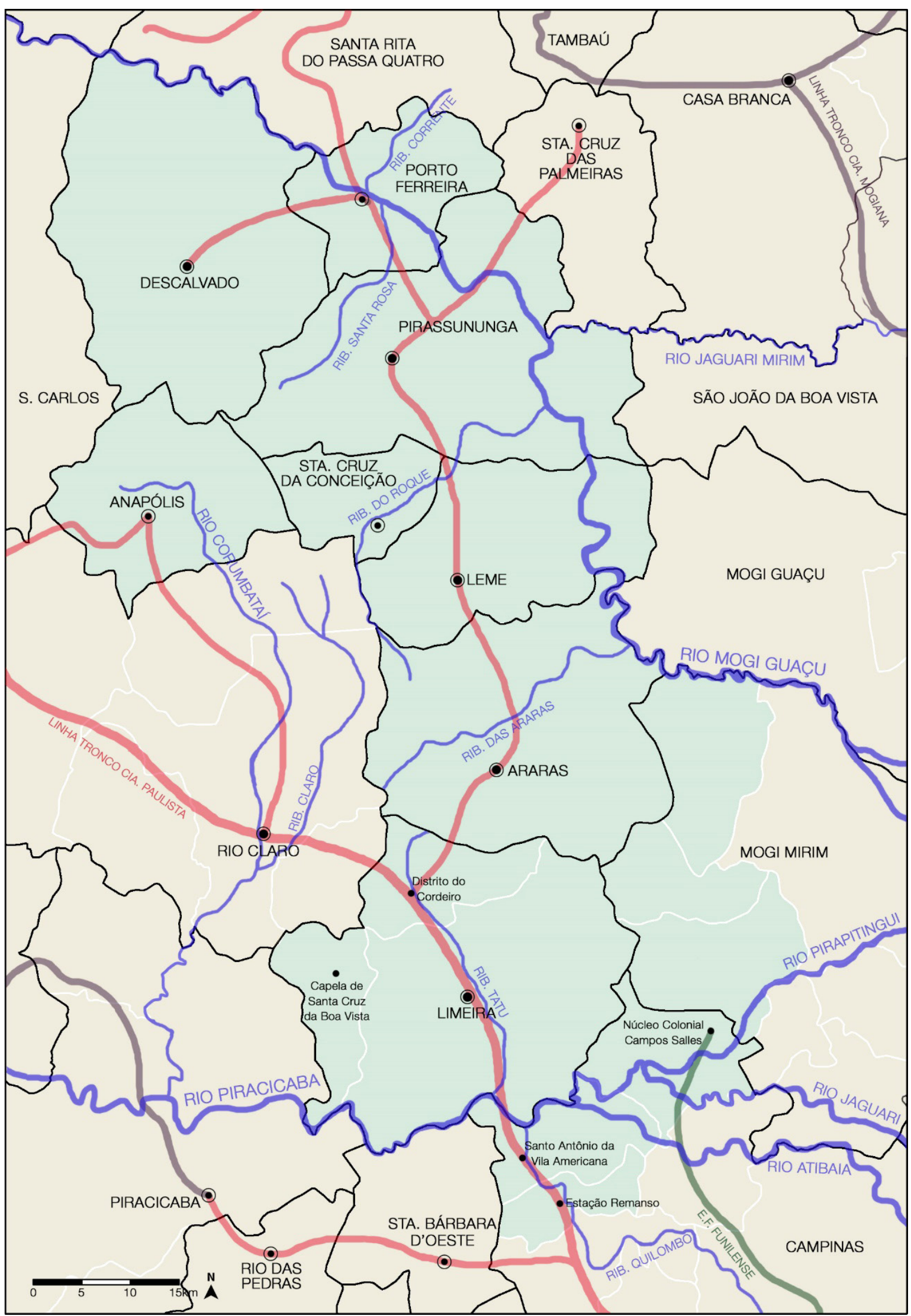


Figura 17: Mapa da Região em 1900. Toda a região norte da Diocese já havia se consolidado como se encontra nos dias atuais. A ferrovia já estava presente cortando todo o território. Em vermelho, encontra-se a linha tronco da Companhia Paulista e o ramal que partia de Cordeiro até Belém do Descalvado. A nordeste, encontra-se a linha tronco da Companhia Mogiana que passava pela região de Casa Branca até Ribeirão Preto, e a sudeste, a linha férrea da Funilense que ia de Campinas até o Núcleo Colonial Campos Salles. Fonte: Elaborado pelo autor.

Baseado em: Fundação Seade (2000) e CESAD FAU.

\section{AS CIDADES DO SÉCULO XX}

\section{O NÚCLEO COLONIAL DE NOVA ODESSA}

A cidade de Nova Odessa nasceu dentro do território de Campinas, sendo anexada posteriormente ao município de Americana. Em 1905, o secretário de agricultura, Doutor Carlos José de Arruda Botelho idealiza a realização de mais um núcleo colonial no eixo da Companhia Paulista. Para isso, adquire a Fazenda Pombal, cujas escrituras foram lavradas em 11 de março deste mesmo ano. O núcleo denominado Nova Odessa recebeu principalmente imigrantes russos e letos, que foram conferindo identidade ao lugar. A região, que já contava com as estações Pombal e Remanso da Companhia Paulista, próximas as terras do núcleo colonial, cresceu rapidamente e foi emancipada da tutela do governo em 1920. Devido a presença dos imigrantes protestantes e judeus, a presença da Igreja tardou a chegar, sendo construída a primeira capela somente em 1916, após a doação de um terreno pelo Governo Estadual. O Distrito de Paz foi criado em 30 de novembro de 1938, sendo anexado a cidade de Americana, da qual foi emancipada em 18 de fevereiro de 1959 (SANTOS NETO, 2006, p.27).

\section{AS PRIMEIRAS MANIFESTAÇÕES DE OCUPAÇÃO NA REGIÃO DO FUNIL - 0 DESENVOLVIMENTO DA REGIÃO LESTE DA DIOCESE DE LIMEIRA}

Apesar das cidades que compõem esta região terem se consolidado ao longo do século XX, as primeiras atividades que nortearam sua ocupação e potencializaram seu desenvolvimento iniciaram em meados do século XIX. A gênese e o desenvolvimento da cidade de Cosmópolis e adjacentes, estão ligados a múltiplos fatores que colaboraram para a ocupação territorial da região da sesmaria do Pirapitinguy, compreendida entre Limeira, Mogi-Mirim e Campinas. As políticas de ocupação territorial e a expansão da mancha urbana, propostas pelo Governo Estadual, as imigrações, a presença de terras pertencentes a relevantes figuras políticas e a implantação de equipamentos ferroviários e industriais, são exemplos de ações que potencializaram o quadro de nascimento e crescimento de vilas na região.

As primeiras manifestações de ocupações e manejo agrícola nesta região datam do final do século XIII e início do século XIX, quando a então sesmaria do Pirapitinguy foi concedida em 1796 ao Tenente Ignácio Ferreira de Sá e ao Coronel Luiz Antônio de Souza. Segundo a carta de concessão; os mesmos adquiram um sitio de Francisco Antunes Xavier e desejavam 
receber do governo mais terras para estabelecer ali um engenho de açúcar:

Carta de sesmaria concedida ao Cel. Luiz Antônio de Souza e ao Tte.Ignacio Ferreira de Sá, que comprarão um sitio de Francisco Antunes Xavier na paragem denominada o Saltinho, no Ribeirão Pirapitinguy, termo da Vila de Mogi-Mirim, com casas e canaviais, onde pretendem estabelecer engenho de fazer açúcar, etc. me pedirão Ihes concedesse da barra do Pirapitinguy abaixo um quarto de légua e da mesma barra para cima légua e um quarto, seguindo o vento que melhor convier aos suplicantes, e de sertão uma légua para nelas estabelecerem uma fábrica como deferido [...] Em 30 de julho de 1799, Antônio Manoel de Mello Castro e Mendonça, Governador, Capitão General da Capitania (BUSCH, 2007, p.24).

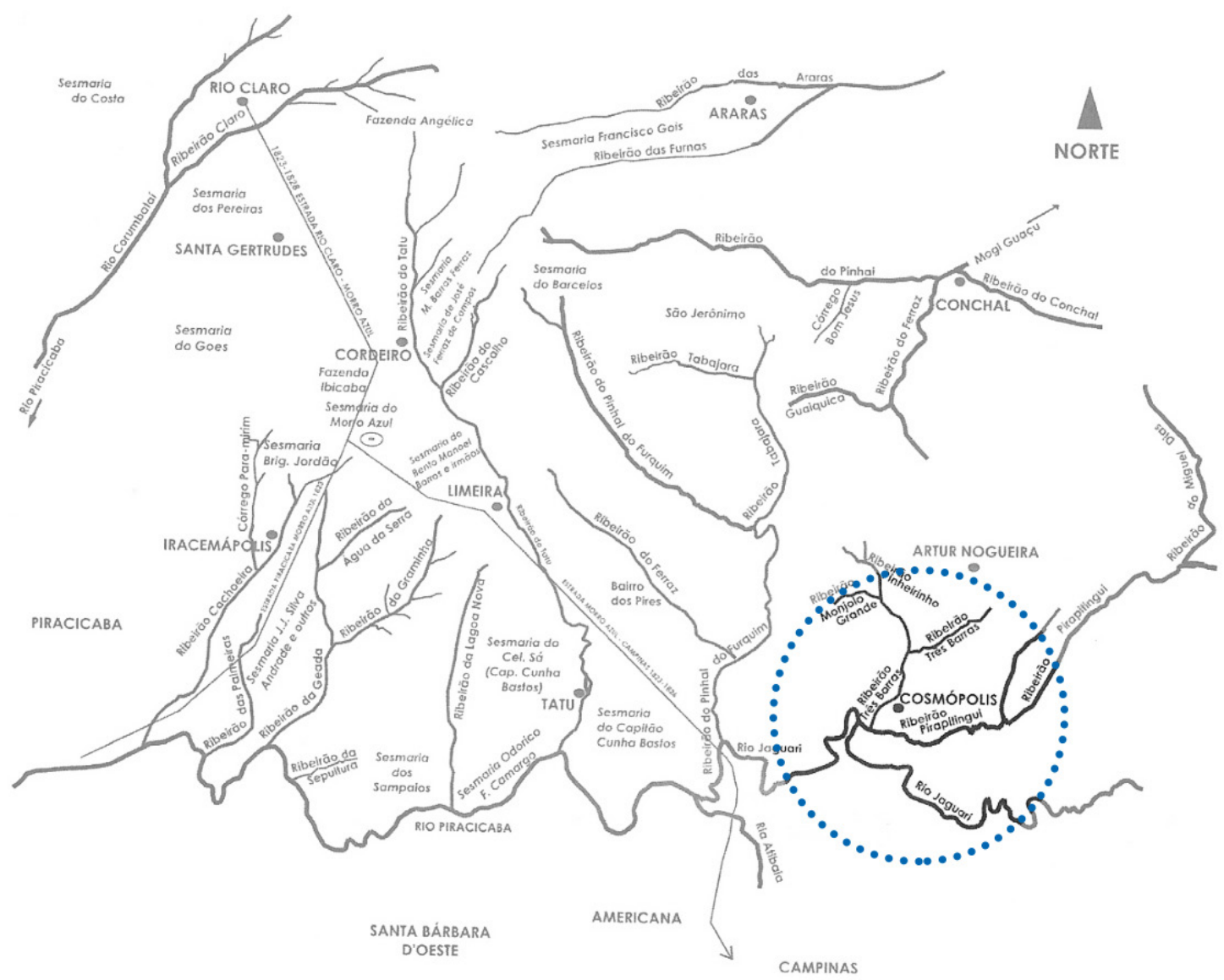

Figura 18: Mapa com as sesmarias da região. Em destaque, a região e sesmarias onde hoje se encontram a cidade de Cosmópolis. Fonte: BUSCH, 2007, p.43. Elaborado pelo autor.

Parte desta sesmaria, que fazia divisa com o Engenho do Tatu foi comprada em 1820 pelo Capitão Luiz Manoel da Cunha Bastos do finado Ignácio Ferreira de Sá, e anexada a sua propriedade (BUSCH, 2007, p.44). Além da venda deste trecho, não há registros de como se deram as transições entre proprietários para a parte restante. A região era também conhecida como Campo das Palmeiras (ATIQUE, 2004, p.37), onde se localizavam diversas 
fazendas ${ }^{23}$, dentre elas a Fazenda do Funil, propriedade que compreendia uma gleba de 5 mil alqueires, e que aparece na listagem dos bens do Padre João Manoel de Almeida Barbosa (1803-1855). Pertencente a nobreza, era formado em direito e foi o 13o Vigário da Matriz da Vila de São Carlos (1838-1855), atual cidade de Campinas, onde também exerceu diversas funções públicas, sendo vereador e juiz de órfãos, além de ser abastado cafeicultor (BRITO apud. FERREIRA, 2011, p.38).

Com sua morte, em 6 de dezembro de 1855, parte da Fazenda do Funil foi destinada em testamento a Sra. Damiana Eugênia de Castro, moradora da cidade de Campinas, de cujo filho o vigário era padrinho. Nascido em 07 de junho de 1851, homônimo do padre, João Manoel de Almeida Barbosa, se tornou coronel e importante cafeicultor da região ao assumir a administração das terras herdadas pela mãe. Esteve ainda junto ao futuro governador do Estado de São Paulo Américo Brasiliense de Almeida Melo, e do futuro presidente da República Manuel Ferraz de Campos Salles no grupo que fundou o jornal "A Província de São Paulo" - atual jornal "O Estado de São Paulo" - em 4 de janeiro de 1875 (FERREIRA, 2011, p.40).

Entre os documentos que descrevem as características região onde se localizava a Fazenda do Funil, está a carta de Miguel Alves Feitosa, que em visita ao local o descreve como uma região prospera e fértil, com diversos cursos d'água e maciços de mata virgem ${ }^{24}$. A grande propriedade que possuía destaque na produção nacional de café - com produção anual entre sete e nove mil arrobas - possuía também outras formas de exploração dos recursos naturais e cultivo do solo (SABARIM, 2010, p.52). Feitosa descreve em sua carta a atividade de extração de madeira de cedro para comercialização para a construção civil e marcenaria - citando inclusive uma loja na avenida Andrade Neves em Campinas para este fim- além da criação de gado e suínos (FEITOSA apud. FERREIRA, 2001, p.87).

No que consta na carta, o Coronel João Manoel era visionário no âmbito do desenvolvimento e da industrialização, tentando diversas vezes utilizar-se dos rios Jaguari, Três Barras e Pirapitingui - presentes na propriedade - como força motriz para a indústria e como meio de transporte, com a construção de um engenho central e com a navegação a vapor do Rio Jaguari, desde a região do salto - formação rochosa que forma queda d'agua afunilada, dando origem ao nome da região - até a Fábrica Carioba - atual Americana, chegando

23 Destaca-se a presença de quatro Fazendas na região, que ao serem paulatinamente compradas, iriam formar uma grande propriedade de seis mil alqueires paulistas $\left(24.200 \mathrm{~m}^{2}\right)$, são elas: Fazenda do Funil, Fazenda da Grama ou Sete Barras, Fazenda Boa Vista e Fazenda São Bento.

24 Miguel Alves Feitosa envia uma carta para o amigo professor e membro da imprensa campineira Henrique de Barcelos, onde relatava a sua visita à Família Barbosa no Funil. A carta foi transcrita posteriormente por Jolumá Brito em sua obra História da cidade de Campinas, no volume 09. 
inclusive a encomendar duas embarcações iguais as que eram usadas no Rio Mogi Guaçu²5. Todos os seus projetos, porém, esbarraram-se em dificuldades técnicas, no caso do engenho central, a negação de recursos por parte do Governo Provincial fez com que o projeto não saíssedo papel, e no caso da navegação, a mudança da estação Santa Bárbara da linha férrea da Companhia Paulista ${ }^{26}$ inviabilizou o trajeto. Sobre a arquitetura deste lugar, Feitosa revela que João Manoel realizou reformas em antigas ruinas para a benfeitoria do café e tentou reativar um antigo engenho de primeira ordem, possivelmente desativado 20 anos atrás ${ }^{27}$, além de construir uma casa sede para sua moradia. No ano de 1887, João Manoel adquire a Fazenda São Bento, que se localizava no território de Mogi Mirim de Joaquim Cyrillo de Oliveira, incorporando as terras e as benfeitorias à sua propriedade ${ }^{28}$.

\section{O PROGRESSO E A PRODUÇÃO AGRÍCOLA DA REGIÃO DO FUNIL}

A qualidade da terra e a expansão da produção do café no sentido oeste do estado de São Paulo, aumentaram significativamente a produção da região. Até então, a entrada no território e o transporte das produções até os centros urbanos- para serem levadas até o porto de Santos- eram realizadas em picadas e estradas rústicas, sempre de forma precacária , como já comentado anteriormente (FERREIRA, 2011, p.88). Não eram diferentes na região do Funil, que possuía o agravante de ter suas estradas intransitáveis ou alagadas nas épocas de cheia, devido à grande quantidade de rios e curso d'água, além do estado precário das pontes sobre os dois grandes rios supracitados, o que encarecia demasiadamente a produção.

Desse modo, em 1889 os produtores da região começam a se reunir buscando uma solução para melhorar o escoamento da produção e o acesso a suas propriedades. Compunham essa comissão o Coronel João Manoel, Barão Geraldo de Resende - proprietário da Fazenda Santa Genebra, onde hoje se localiza o distrito de Barão Geraldo -, João Batista de Barros Aranha, José Guatemozin Nogueira e Francisco de Paula Camargo - proprietário da Fazenda São Bento, cuja colônia viria a ser o núcleo formador da cidade de Paulínia (FERREIRA, 2011, p.40).

A comissão encontrou como saída a construção de um carril agrícola com $40 \mathrm{~km}$ de comprimento, que deveria ligar o centro da cidade de Campinas com a Fazenda do Funil, até então a mais distante da região. Para tal empreitada foi criada uma empresa anônima, cujos

25 Trata-se de embarcações a vapor que eram utilizadas no rio Mogi Guaçu pela Companhia Paulista em Porto Ferreira.

26 A estação Santa Barbara da Companhia Paulista de Trens corresponde respectivamente à estação da cidade de Americana, inaugurada em 1875. Sua implantação estava prevista junto ao complexo Carioba, próximo ao Rio Piracicaba, porém, a mudança para outro sitio inviabilizou os planos do coronel João Manoel.

27 Possivelmente trata-se do Engenho construído com a doação da sesmaria.

28 Sobre esta transação, conta uma ação ordinária localizada no Centro de Memória da Unicamp. (Caixa 312, processo 05989) (FERREIRA, 2011, p.40). 
acionistas deveriam contribuir com $10 \%$ de juros de seu capital. O orçamento inicial para a construção do caminho de ferro, do modo mais econômico possível, foi orçado em trezentos contos de réis.

Atingido o montante pecuniário necessário, em 24 de agosto de 1890 foi criada oficialmente a Companhia Carril Agrícola Funilense, cujos incorporadores eram os fundadores da antiga empresa anônima. Neste mesmo ano, o Coronel João Manoel colocou suas terras a disposição para a consolidação de burgos agrícolas, para acolhimento de imigrantes em troca de isenções de impostos e empréstimos para a construção da via férrea. Após obterem autorização da Companhia Paulista de Vias Férreas e Fluviais, é celebrado junto ao Governo do Estado em 13 de abril de 1891 o contrato com a concessão e a autorização para a construção da ferrovia. Cabe destacar que entre as cláusulas do contrato, encontrava-se no artigo 9ㅇ, a obrigatoriedade da companhia de transportar gratuitamente: imigrantes e seus pertences (item E), e sementes e mudas dadas pelo governo aos produtores (item F), o que enfatiza a política de ocupação territorial e acolhimento aos imigrantes, com vistas a expansão da produção agrícola e substituição da mão de obra escrava (FERREIRA, 2011, p.90).

As obras superaram o orçamento previsto, e ainda em 1891 são paralisadas devido à falta de recursos da companhia. Neste período, o interesse pela região do Funil que já era grande, passou a ser ainda maior, não só pela produção agrícola, como também pelas riquezas naturais e as possibilidades econômicas que a região possibilitava. Por isso, em 6 de maio deste mesmo ano, a Fazenda do Funil é vendida pelo Coronel João Manoel a Companhia SulBrasileira Territorial e Colonizadora ${ }^{29}$, juntamente com o contrato de concessão dos burgos agrícolas, que caducaram sem serem cumpridos (FERREIRA, 2011, p.118).

A paralisação das obras e a escassez de recursos fizeram com que os dirigentes da Companhia Carril Agrícola Funilense fossem até a Câmara de Campinas para obter recursos para sua conclusão. Na sessão de 16 de dezembro de 1995, o vereador Antônio Lobo, após realizar visitas na região beneficiada com o carril, levanta a questão da empresa Companhia SulBrasileira possuir terras dentro da zona aludida e ser beneficiada futuramente com isso. Tal fato faz com que a Câmara dos Vereadores proponha a Companhia Carril Funilense que para a concessão de juros para a continuidade das obras, tenha-se como contrapartida a compra de lotes e glebas junto a futura linha férrea para a implantação de núcleos coloniais, como se vê na proposta apresentada em 28 de dezembro de 1895:

A Companhia, em compensação à garantia de juros que lhe é concedida, fará a aquisição

29 A Companhia Sul-Brasileira Territorial e Colonizadora foi criada anos antes pelo Barão Geraldo de Rezende e tinha como intuito principal a formação de núcleos coloniais para a fixação da mão de obra imigrante, além de repassar assim ao Estado os ônus referentes a vinda e o assentamento destes trabalhadores. (ATIQUE, 2004, p.37). 
de 1.200 alqueires de terras ao preço da Lei 323 do Estado, de 22 de junho de 1895, sobre a base mínima de $10 \$ 000$ o hectare, para colocação de núcleos agrícolas e coloniais e as transferirá à Câmara ao mesmo preço [...] sempre a margem da linha projetada. As terras entregues à municipalidade serão transferidas ao governo do Estado para que se instale nas mesmas os núcleos coloniais a que se refere o artigo 3‥ Os núcleos serão instalados em extensão agrária no máximo de 400 alqueires e no mínimo de 300, sem solução de continuidade. A medição das terras, bem como a demarcação delas e a separação dos lotes, serão feitas pelo governo, e às custas desse (FEREIRA, 2011, p.94).

O texto que se tornaria a Lei no 47 foi votada e aprovada na sessão de 04 de janeiro de 1896. Contudo, a lei não chegou a ser cumprida e obter resultados, pois no mesmo ano, o Governo do Estado sobrepôs-se ao Governo Municipal, e liberou os recursos necessários para a continuação da construção do carril agrícola através da Lei no 423 de 29 de julho de 1896, na qual além de conceder nove contos de réis por quilometro construído, prorrogou os prazos para a conclusão da mesma. Em contrapartida, o governo estabeleceu que a companhia carril deveria conceder ao estado 1.200 alqueires de terra, como determinado no artigo 70.:

A companhia concessionária, para gozar do favor que Ihe é concedido por esta lei, deverá transferir ao Estado, sem indenização e livre de qualquer ônus, a inteira propriedade de 1.200 alqueires (mil e duzentos) de terras, escolhidas livremente pelo Governo dentre as que a mesma Companhia possui e vão ser servidas pela linha férrea a construir, sendo aquelas terras empregadas pelo Governo na colonização (FERREIRA, 2011, p.95).

A doação das terras foi realizada em 02 de maior de 1898 pela Companhia Sul-Brasileira Territorial e Colonizadora, certamente pelos benefícios que a conclusão da estrada de ferro traria a empresa. Com isso, as obras são novamente retomadas, e diversas subvenções do estado são realizadas para sua conclusão. Conforme os trechos iam ficando prontos as composições começavam a operar, até a inauguração total da linha em 18 de setembro de 1889.

No tocante à ocupação urbana, não se encontram junto aos arquivos competentes dados de assentamentos urbanos ou povoados nessa região, apenas a habitação dos proprietários e funcionários das fazendas. É notável que em 1870, o Governo da Província notifica aos colonos presentes na região do Funil que o Governo Imperial, através do Ministério da Agricultura, encontra-se a disposição para auxiliar parentes e conterrâneos que desejassem estabelecer -se naquele ponto, com a contribuição de 70 contos de réis por adultos e 30 contos de réis por crianças. No entanto, as primeiras manifestações de ocupação territorial e adensamento populacional- além das ligadas as fazendas- irão acontecer no final do séc. XIX (FERREIRA, 2011, p.45).

Em 1896, Manuel Ferraz de Campos Salles, então Governador do Estado de São Paulo, no cumprimento de suas metas de fixação do trabalhador em solo nacional e ocupação territorial, inicia a criação de núcleos coloniais, tendo a cidade de Campinas, sua terra natal, como modelo. Embora fosse de seu interesse a criação de um núcleo na região do bairro 
Rebouças - atual cidade de Sumaré-, Campos Salles opta pela região do Funil onde já possuía terras destinadas a esse fim (FERREIRA, 2011, p.46).

O local que fora intitulado "Núcleo Campos Salles" foi criado através do Decreto 502A de 04 de dezembro de 1897, sendo repartido em 200 lotes com uma casa em cada propriedade. A princípio este núcleo deveria receber apenas famílias suíças, o que não ocorreu, pois muitas não se adaptaram ao clima e buscaram colônias mais ao sul do pais, assim outras nacionalidades passaram a ocupar o conjunto. O núcleo que recebeu 44 pessoas na primeira leva passou a crescer e logo contava com a presença de uma Escola Alemã e uma Igreja Protestante, devido à religião dos colonos.

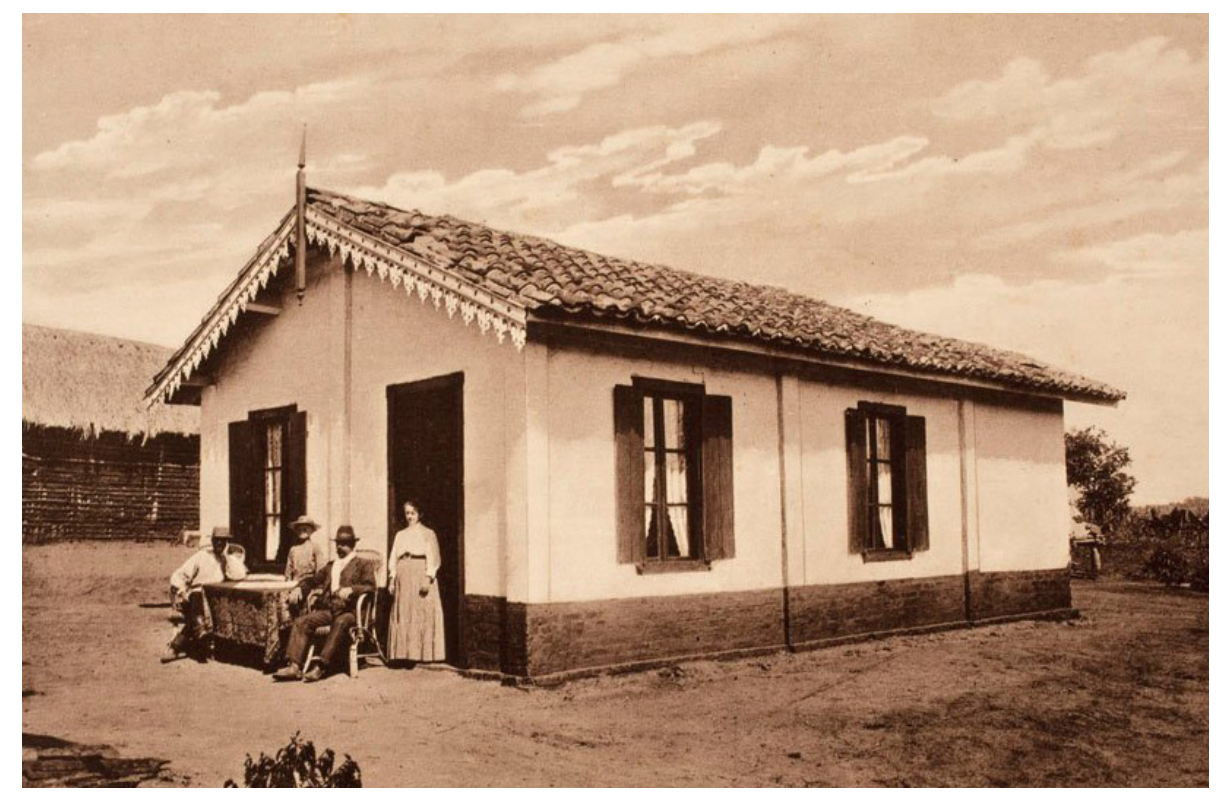

Figura 20: Residência do Núcleo Colonial Campos Salles. Fonte: FERREIRA, 2011, p. 48.

\section{A NOVA VENDA DA FAZENDA FUNIL}

A importância da região com sua produção e seu potencial econômico eram atrativos para negociatas e aquisições de terras, que foram potencialmente retomadas com a conclusão da via férrea. Em 1889, quando a propriedade pertencia ainda ao Coronel João Manoel, a família Nogueira encomendou ao engenheiro civil Francisco Ferreira Ramos um estudo de viabilidade econômica da Fazenda do Funil (FERREIRA, 2011, p.119). O relatório apresentava as características geográficas e hídricas da região, bem como trazia números referente as produções agrícolas, seus manejos, gastos e lucros. Deste relatório é importante destacar a consideração do engenheiro quanto à presença dos cursos d'agua e a possibilidade da utilização da força destes, tanto para a indústria de energia elétrica, quanto para a criação de engenhos para o trato do algodão - que segundo o mesmo, poderia ser mais cultivado na região -, quanto para o manejo da cana de açúcar, grande atrativo para cultivo nesta 
região, ficando na frente inclusive do café, que era o produto de maior renda no momento. O documento aponta ainda um completo conjunto edificado para a produção de álcool, com moendas, tanques, alambiques e depósitos. O último fator apresentado pelo analista é referente ao tamanho da propriedade, ideal para a manutenção das atividades agrícolas e a realização de loteamentos privados, o que aponta com cálculos e projeções, ser uma atividade rentável e muito lucrativa nos próximos anos (RAMOS apud. FERREIRA, 2011, p.134).

No entanto, apenas em 1898, a Família Nogueira e agregados formaram a Companhia Nogueira, e adquirem propriedade. A Companhia Nogueira era uma sociedade formada pelos irmãos José Paulino, Sidrack e Artur Nogueira e por Antônio Carlos da Silva Telles ${ }^{30}$ e Paulo de Almeida Nogueira, genro de José Paulino. O interesse pela propriedade não se deu de forma espontânea, mas de forma articulada, devido ao conhecimento das potencialidades econômicas a serem exploradas ${ }^{31}$. A Companhia Nogueira adquire então a Fazenda do Funil pelo valor de 360 contos de réis em 2 de março de 1898, comprometendo-se a cumprir as obrigações anteriormente acordadas junto ao governo pelos antigos proprietários, quanto ao fornecimento de materiais para a via férrea e aos assuntos relacionados ao núcleo colonial (FERREIRA, 2011, p.133).

\section{A INDÚSTRIA E O DESENVOLVIMENTO TERRITORIAL - A USINA ESTER E A CRIAÇÃO DA VILA DE COSMÓPOLIS}

Após a aquisição das terras da Fazenda Funil, a Companhia Nogueira continuou com os investimentos em infraestrutura, como a conclusão da Carril Agrícola Funilense, importante para escoar a produção da região e à expansão das atividades do primitivo alambique, além de colocar à venda parte de suas terras para angariar fundos para o empreendimento que daria origem a futura Usina Ester. De tal forma conseguiria além do levantamento pecuniário, adensar a região, trazendo deste modo mão de obra próxima a propriedade.

Em 17 de janeiro 1901, a Companhia Nogueira criou um loteamento em suas terras denominando-o "Villa de Cosmópolis", cujo traçado corresponde hoje ao centro da atual cidade de Cosmópolis. O nome dado à vila é de origem incerta, acredita-se que o mesmo tenha ocorrido devido à presença de muitos imigrantes na região, fazendo alusão a uma cidade-universo (FERREIRA, 2011, p.147).

30 Antônio Carlos da Silva Telles ingressou no negócio de uma forma inusitada. Segundo consta, era proprietário de tropas de muares em Campinas e ao ganhar um bilhete de loteria, foi pedir conselhos para José Paulino de como investir seu dinheiro, que o convenceu a entrar na sociedade (ATIQUE, 2004, p.37).

31 A Família Nogueira, que estava ligada a produção do café em Campinas nas Fazendas Roseira e São Quirino, realizou investimentos em outros ciclos econômicos, como a criação de gado, atividades na imprensa e na montagem de uma usina de açúcar, além dos investimentos em ferrovias (ATIQUE, 2004, p.37). 


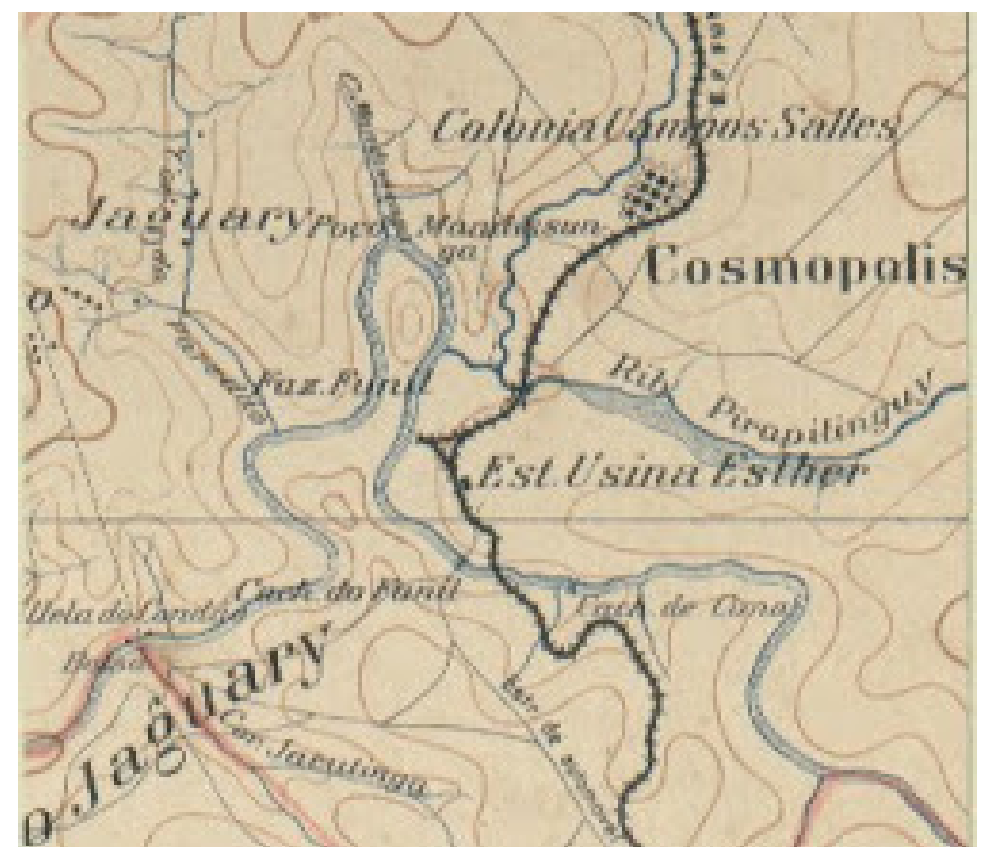

Figura 20: Ampliação do mapa do estado de São Paulo com trecho do Funilense passando pela região de Cosmópolis. Destaque para a Estação da Usina Ester e o Núcleo Colonial Campos Salles. Fonte: Estações Ferroviárias do Brasil.
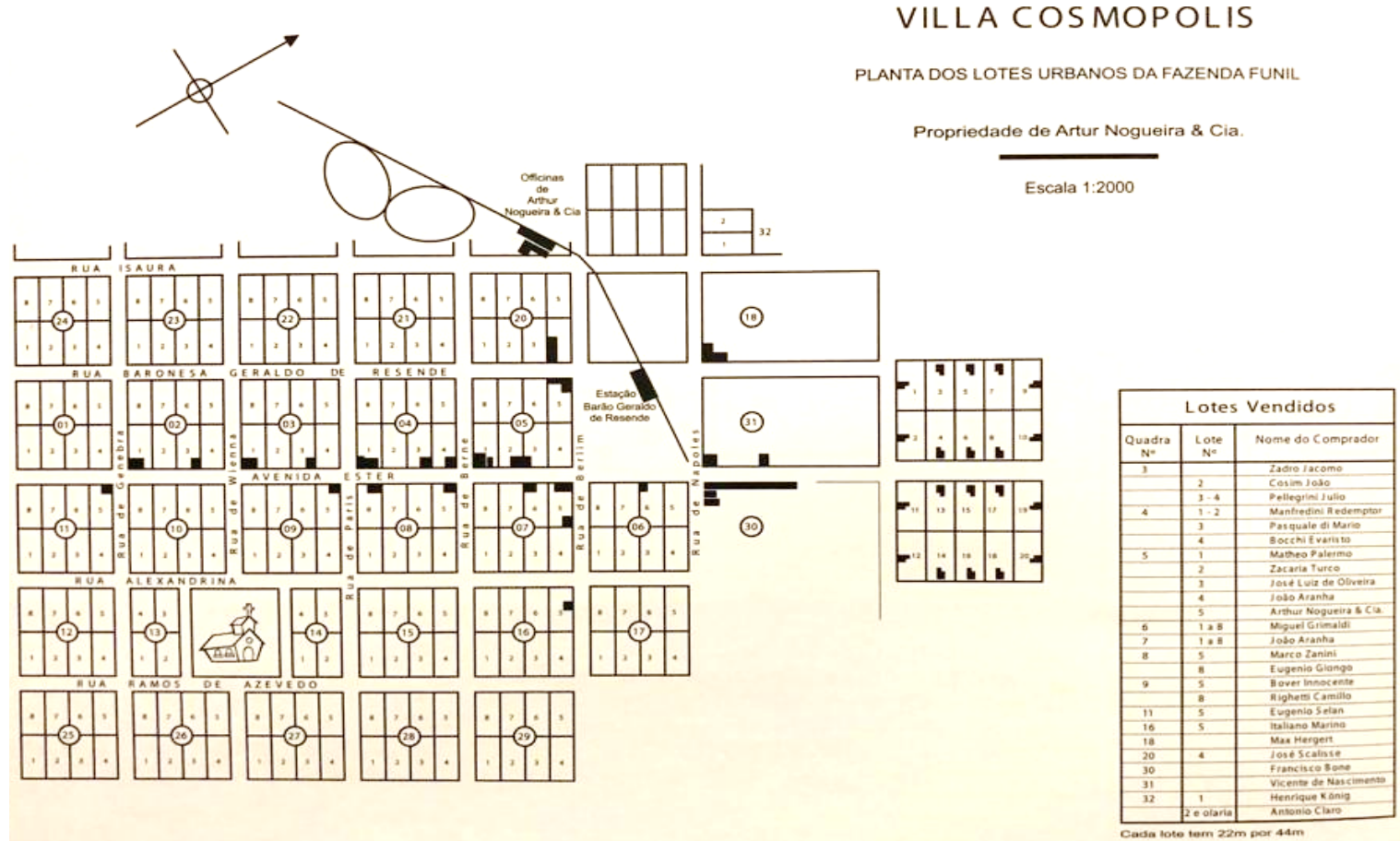

Figura 21: Esquema feito a partir da planta original desenvolvida em 1901 para o Loteamento realizado pela Família Nogueira em sua propriedade, que configura o atual centro da cidade de Cosmópolis. É interessante notar, que os primeiros lotes comprados, estão juntos a Avenida Ester, e não próximos ao largo da Igreja Matriz, localizado na Rua Ramos de Azevedo. Fonte: FERREIRA, 2011, p. 14.

Em 1903, deu-se início ao cultivo em larga escala da cana de açúcar nas terras da propriedade, cuja produção destinava-se a abastecer o alambique. Em 1905, com o intuito de ocupar o território, e obter mais mão de obra para os trabalhos na formação dos canaviais e no próprio alambique, foram doados ao Governo do Estado mais 200 alqueires para a expansão 
do Núcleo Colonial ${ }^{32}$, trecho este que passou a ser denominado Seção Artur Nogueira, que daria origem à cidade do mesmo nome. Neste mesmo ano foi concluída a primeira safra das plantações na propriedade, com uma colheita de 40.000 sacas $(60 \mathrm{~kg})$ de açúcar, marcando o início do cultivo da cana-de-açucar em larga escala, transformando assim o antigo alambique em uma estrutura semelhante à encontrada nos Engenhos Centrais ${ }^{33}$. A primeira safra de seus próprios canaviais e as atividades em larga escala marcam a origem da Usina Ester, que foi estabelecida como Sociedade Anônima no ano de $1907^{34}$.

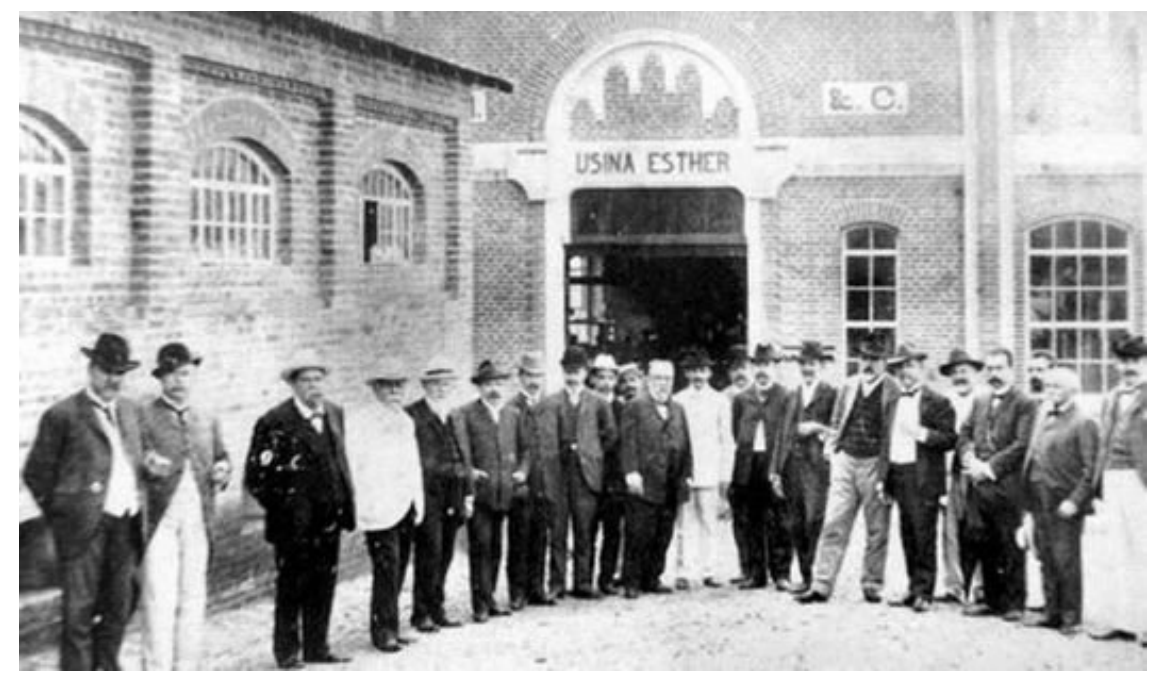

Figura 22: Família Nogueira e a Usina Ester em 1905, ao fundo, os edifícios projetados por Ramos de Azevedo Fonte: FERREIRA, 2011, p. 123.

O aglomerado de casas que se formou no loteamento da Vila de Cosmópolis, e a proximidade com o Núcleo Colonial Campos Salles, possibilitaram a criação do Distrito de Cosmópolis em 27 de novembro de 1906 através da Lei no 1.024³. A estrada de Ferro Funilense foi novamente prolongada pelo Governo em 1910, agora chegando até o Rio Mogi Guaçu, onde foi estabelecida a Estação Pádua Salles, a última da linha e onde seria implantado no ano seguinte mais um núcleo colonial ${ }^{36}$.

32 Tal doação aconteceu em troca da expansão da Linha Férrea até a Fazenda São Bento, propriedade dos Nogueiras, conforme se encontra nas cláusulas do contrato assinado em 08 de setembro de 1905. É importante destacar que a Linha Férrea Funilense passou aos cuidados do governo em 1904, após seu estado precário de operação e incapacidade financeira (FERREIRA, 2011, p.62).

33 Os engenhos centrais foram construídos em diversas localidades e trabalhavam processando a cana produzida por terceiros, e não necessariamente tinham um cultivo próprio. Tal modo de operação foi adotado no início pela Usina Ester, que comprava toda a cana de açúcar produzida no eixo da Funilense, enquanto não formava seus próprios canaviais (ATIQUE, 2004, p.41).

34 O nome Ester é dado em homenagem a esposa (Ester Nogueira) do primeiro presidente da sociedade, Dr. Paulo Nogueira.

35 O Núcleo Colonial Campos Salles só foi emancipado no ano de 1914, quando deixou de ser administrado pelo governo (FERREIRA, 2001, p.108).

36 O prolongamento da linha beneficiou a região com o nascimento e o desenvolvimento de novas povoações que se tornaram cidades, como será mostrado a seguir. São elas: Artur Nogueira, Engenheiro Coelho (antiga Guiaquica) e Conchal, além de desenvolver o distrito de Tujuguaba e o Núcleo Colonial Martinho Prado Junior, hoje distrito de Mogi Guaçu. 


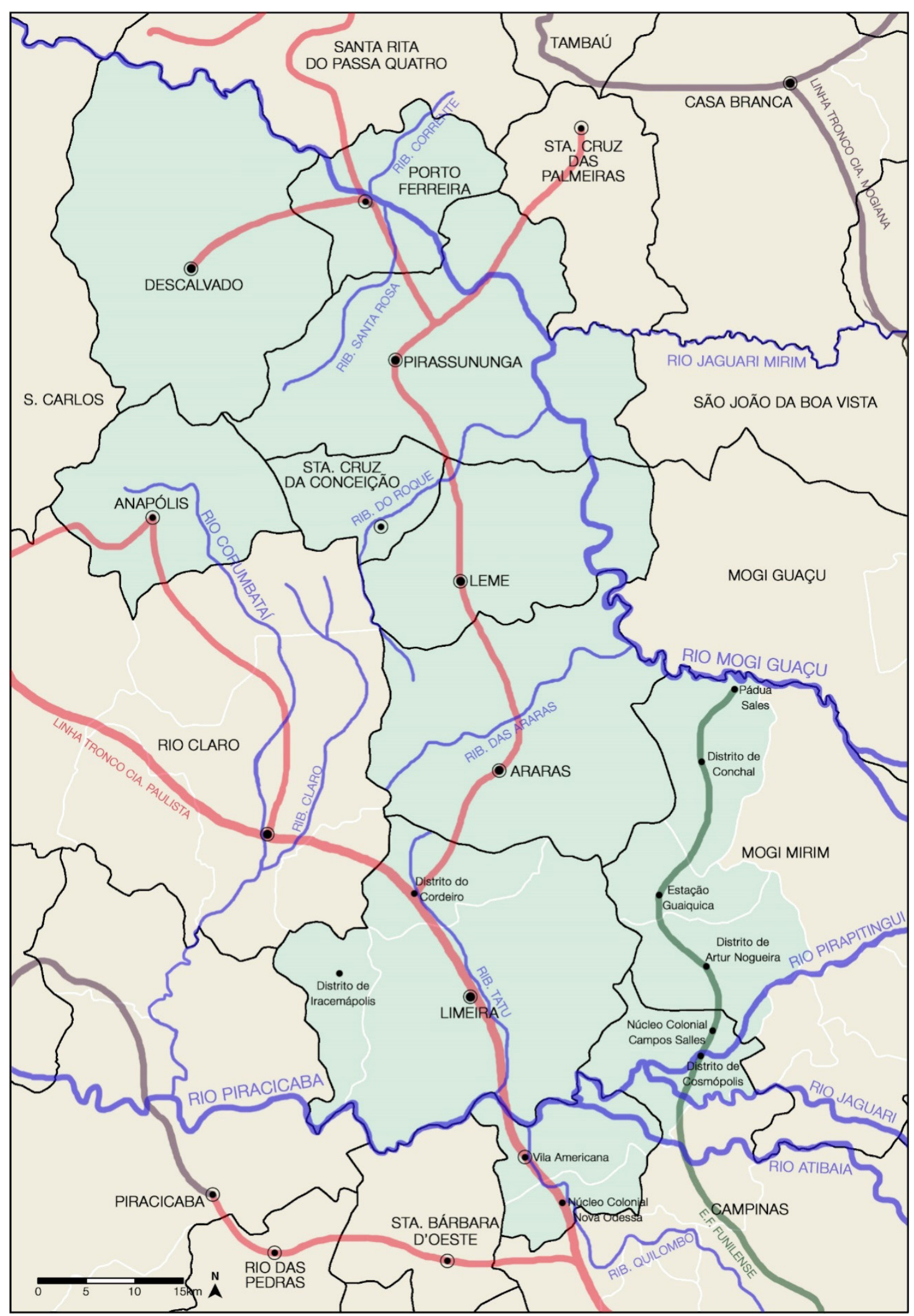

Figura 23: Mapa da região em 1930. Poucas são as alterações nas cidades quem compõem o eixo da Companhia Paulista, apenas a criação dos distritos de Iracemápolis e Cordeiro. Na região leste do território da futura Diocese de Limeira, a linha férrea da Funilense é prolongada até a estação Pádua Salles junto ao rio Mogi Guaçu. Fonte: Elaborado pelo autor. Baseado em: Fundação Seade (2000) e CESAD FAU. 
Somente em 1944 o distrito foi elevado à categoria de cidade. Como apontado anteriormente, a cidade de Cosmópolis é produto de uma soma de fatores: a construção da Estrade de Ferro Funilense, o Núcleo Colonial Campos Salles, o loteamento da Usina Ester e a sua intensa atividade no território.

\section{OUTRAS CIDADES QUE NASCERAM NO EIXO DA FUNILENSE ARTUR NOGUEIRA - UMA EXPANSÃO DO NÚCLEO COLONIAL}

Como já apontado, a cidade de Artur Nogueira surgiu com um prolongamento do Núcleo Colonial Campos Salles feito pelo Major Artur Nogueira em 1905. A ferrovia atingiu a seção "Arthur Nogueira" em 1907, quando o povoado começou a se desenvolver. A construção da capela dedicada à Nossa Senhora das Lágrimas ocorreu em 1916, mesmo ano de sua elevação a Distrito de Paz. Seu desmembramento da cidade de Mogi Mirim aconteceu em 24 de dezembro de 1944, quando foi então elevada a município.

\section{A ESTAÇÃO PÁDUA SALLES E A CIDADE DE CONCHAL}

A zona do Conchal, como era conhecida a região logo além da região do Funil, pertencente ao município de Mogi Mirim, começou a se desenvolver com a implantação de 3 núcleos coloniais em terras do governo. Em 1909, o Governo Estadual estudou implantar os núcleos; Barão de Parnaíba, Visconde de Indaiatuba e Martinho Prado em região próxima ao rio Mogi Guaçu, o que foi realizado através de decreto em 28 de março de 1911 (FERRARI, 2011). O acesso à ferrovia foi essencial para o desenvolvimento destes núcleos, que quando emancipados, se fundiram e em 30 de dezembro de 1919 formaram o distrito de Conchal. A elevação a município ocorreu em 24 de dezembro de 1948. 


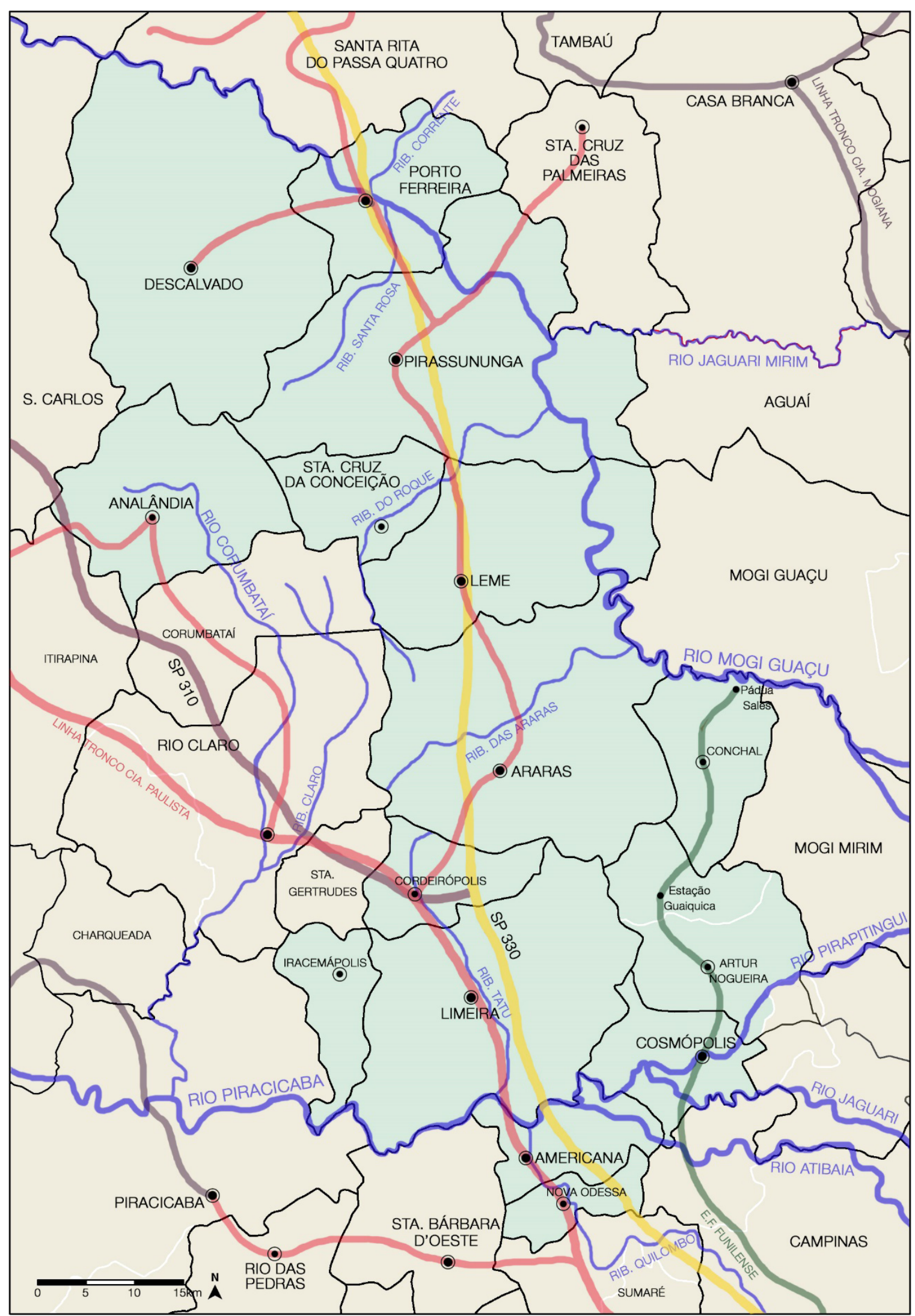

Figura 24: Mapa da região em 1960. O território estava quase todo conformado como se encontra atualmente. Nota-se a construção das Rodovias Anhanguera (SP-330) em amarelo, e Washington Luís (SP-310) em roxo.

Fonte: Elaborado pelo autor. Baseado em: Fundação Seade (2000) e CESAD FAU. 


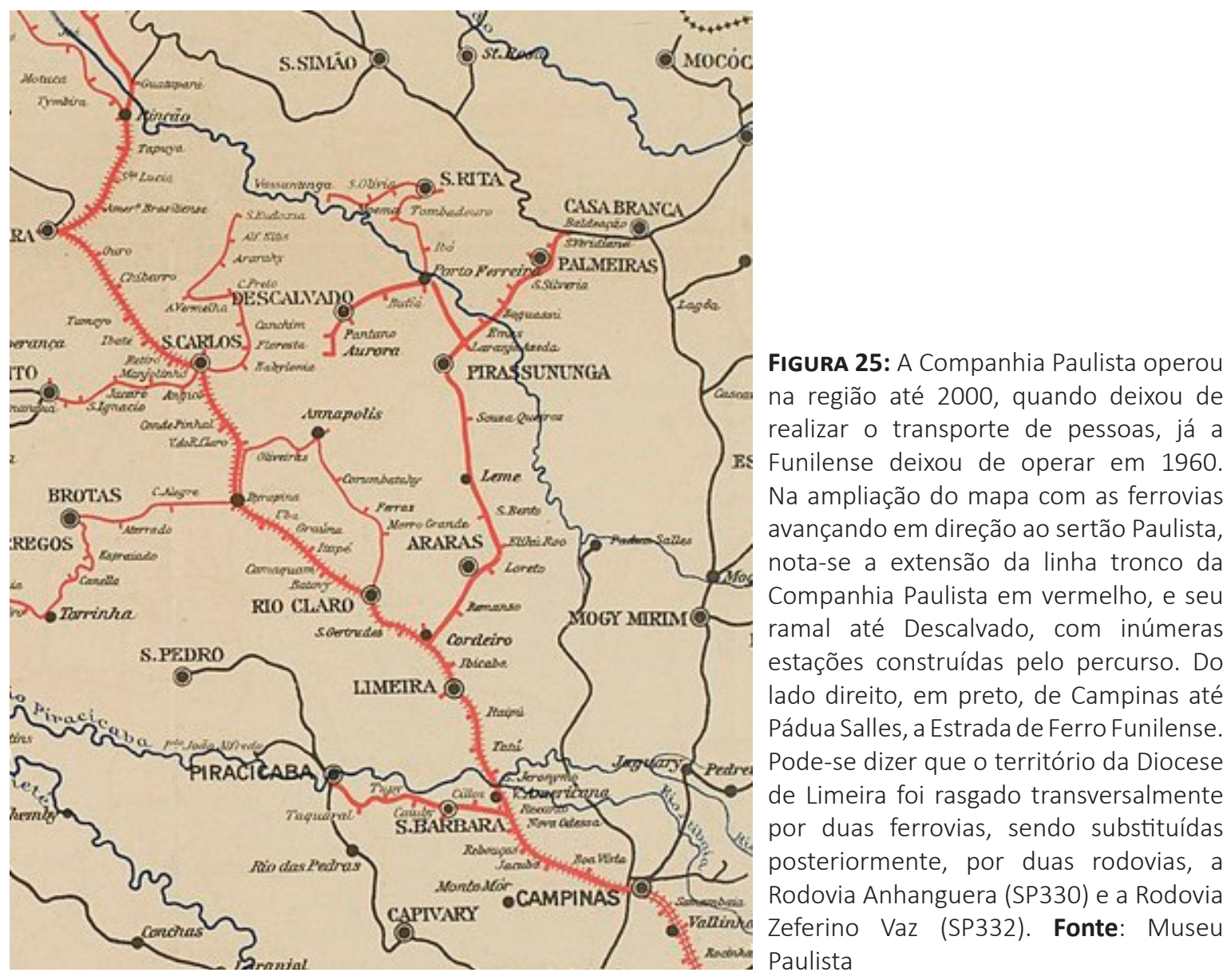

\section{DE GUIAQUICA À ENGENHEIRO COELHO}

A cidade de Engenheiro Coelho, cujo nome é uma homenagem a José Luiz Coelho, engenheiro e inspetor da Estrada de Ferro Funilense, originou-se de da Fazenda São Pedro e da chegada da estação da Funilense em 1912. A estação Guiaquica, como era chamada antigamente, foi criada para auxiliar o escoamento da produção de café e algodão da região, dentro da fazenda de Júlio Cardoso de Moraes, posteriormente vendida ao belga Pedro Heremam (FÁVERO, 2011). Em 1936, foi construída uma capela em devoção a São Pedro, próximo à estação, onde formou-se um pequeno aglomerado de casas. Após sucessivos loteamentos realizados pelos proprietários das terras ao redor, foi se criando um núcleo urbano que possibilitou a criação de um Distrito de Paz em 14 de maio de 1980. A sua emancipação do município de Artur Nogueira ocorreu em 30 de dezembro 1991, configurando desta forma o território da Diocese de Limeira tal como ele se apresenta hoje, composto por 16 municípios, sendo Engenheiro Coelho o mais novo deles. 


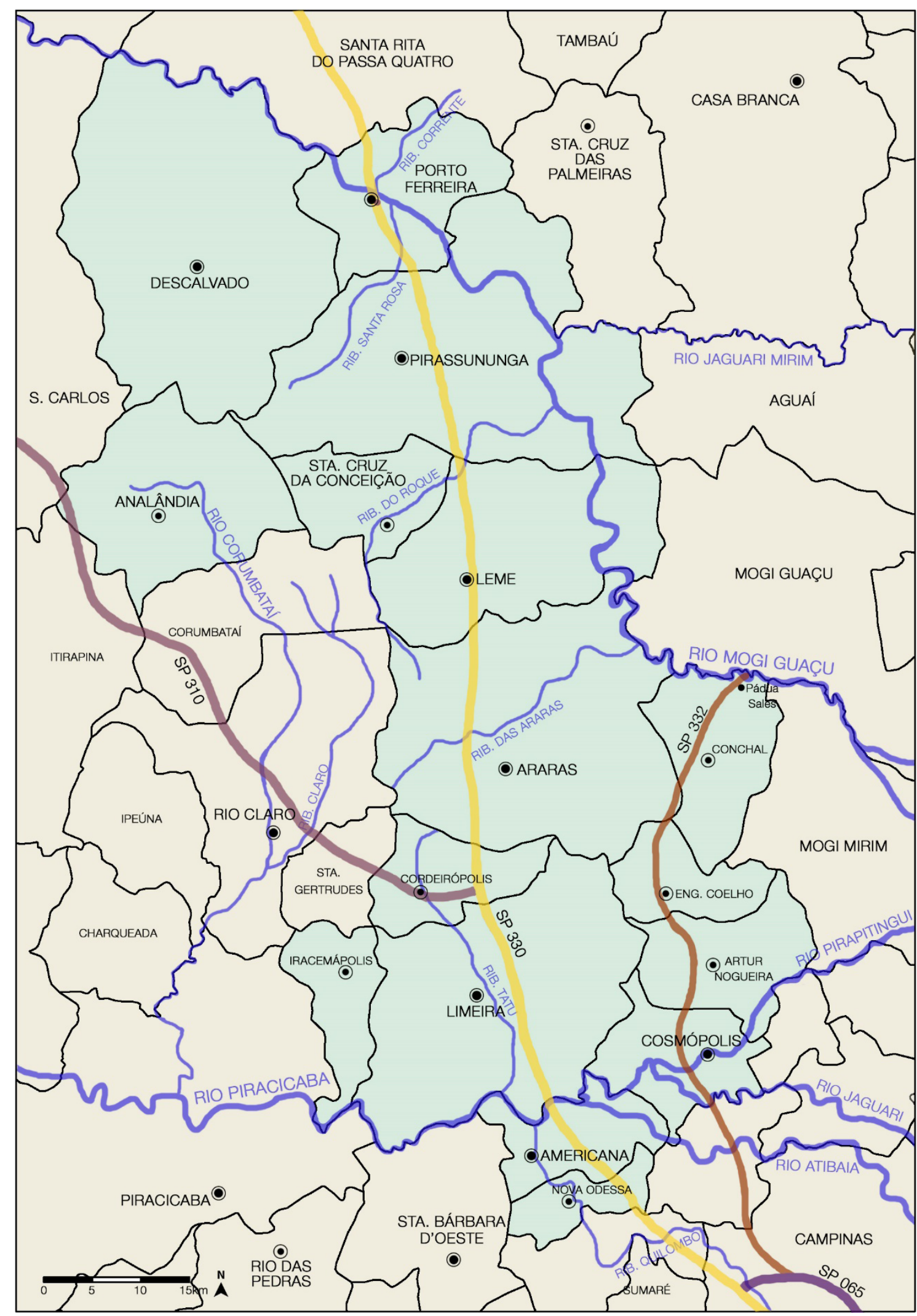

Figura 26: Mapa da região atualmente, com os 16 municípios e suas respectivas divisões territoriais. Nota-se o desaparecimento da ferrovia e a expansão da malha viária, com a construção da Rodovia Zeferino Vaz (SP332), em marrom a direita, além de outras vicinais e estradas locais não presentes no mapa. Fonte: Elaborado pelo autor. Baseado em: Fundação Seade (2000) e CESAD FAU. 
Como vimos, as cidades possuem datas e determinantes diferentes no processo de consolidação de suas urbes e na promulgação dos decretos que thes foram permitindo subir na hierarquia dos espaços urbanos brasileiros, de acordo com a legislação de cada período. No quadro síntese abaixo encontram-se dispostas todas as cidades que compõem a Diocese de Limeira e as datas relevantes para o entendimento de sua gênese e crescimento histórico. O item 'capela' ou 'loteamento' refere-se ao primeiro ato embrionário de cada local, a depender da época de sua formação. O segundo item apresenta a elevação da primeira igreja do local à condição de freguesia ou paróquia. A elevação a vila ou a distrito (termo utilizado no período republicano), está disposta na terceira coluna, ao lado do item de elevação ao título de cidades. A chegada da ferrovia, por ser paradigmática na região, como foi apontado no decorrer do capitulo, é apresentada na última coluna, onde: C.P refere-se à Companhia Paulista e E.F.F. à Estrada de Ferro Funilense.

No que se refere à criação das paróquias, nota-se que, nas cidades mais recentes, a paróquia foi criada posteriormente à criação do distrito (vila), o que não acontecia nas cidades coloniais e imperiais. As questões que envolvem a vida paroquial e o edifício da Igreja Matriz, bem como o processo vivenciado pela Igreja para se acomodar no novo regime governamental do país, são assuntos tratados no capítulo seguinte.

\begin{tabular}{|c|c|c|c|c|c|}
\hline \multicolumn{2}{|c|}{ QUADRO SINTTESE DE FORMAÇÃO DAS CIDADES DA DIOCESE DE LIMEIRA } \\
\hline CIDADES & $\begin{array}{c}\text { CAPELA OU } \\
\text { LOTEAMENTO }\end{array}$ & $\begin{array}{c}\text { FREGUESIA OU } \\
\text { PARÓQUIA }\end{array}$ & $\begin{array}{c}\text { VILA OU } \\
\text { DISTRITO }\end{array}$ & $\begin{array}{c}\text { ELVAÇÃO A } \\
\text { CIDADE }\end{array}$ & $\begin{array}{c}\text { CHEGADA DA } \\
\text { FERROVIA }\end{array}$ \\
\hline LIMEIRA & 1826 & 1831 & 1844 & 1875 & (C.P) 1876 \\
\hline PIRASSUNUNGA & 1828 & 1842 & 1865 & 1879 & (C.P) 1878 \\
\hline DESCALVADO & 1832 & 1844 & 1865 & 1889 & (C.P) 1883 \\
\hline SANTA CRUZ DA CONCEIÇÃO & 1836 & 1879 & 1889 & 1898 & \\
\hline PORTO FERREIRA & 1860 & 1888 & 1896 & 1906 & (C.P) 1880 \\
\hline ARARAS & 1862 & 1869 & 1871 & 1879 & (C.P) 1877 \\
\hline AMERICANA & 1875 & 1900 & 1904 & 1924 & (C.P) 1875 \\
\hline LEME & 1877 & 1889 & 1890 & 1895 & (C.P) 1877 \\
\hline CORDEIRÓPOLIS & 1885 & 1901 & 1889 & 1944 & (C.P) 1876 \\
\hline ANALÂNDIA & 1887 & 1889 & 1890 & 1906 & (C.P) 1884 \\
\hline IRACEMÁPOLIS & 1891 & 1936 & 1923 & 1953 & \\
\hline NOVA ODESSA & 1906 & 1948 & 1938 & 1959 & (C.P) 1875 \\
\hline COSMÓPOLIS & 1905 & 1915 & 1914 & 1944 & (E.F.F) 1889 \\
\hline ARTUR NOGUEIRA & 1905 & 1934 & 1916 & 1944 & (E.F.F) 1907 \\
\hline CONCHAL & 1910 & 1921 & 1919 & 1948 & (E.F.F) 1912 \\
\hline ENGENHEIRO COELHO & 1936 & 2000 & 1980 & 1990 & (E.F.F) 1912 \\
\hline
\end{tabular}





$$
\text { CAPITTULO O2 }
$$




\section{CAPITULO O2}

\section{CATOLICISMO E ARQUITETURA} A PRESENÇA DA IGREJA E SEUS EDIFICIOS

As igrejas foram, desde o início da colonização brasileira, edifícios prestigiados e construídos com esmero e dedicação pelos seus comitentes. Sendo órgão oficial do Estado até o fim do Império, foram empregados nestes edifícios as melhores técnicas e materiais construtivos disponíveis, em projetos arquitetônicos muitas vezes realizados pelos melhores profissionais existentes.

Neste capitulo, abordaremos o percurso realizado pela Igreja para se acomodar à nova forma de governo instituída na República, bem como a expansão de suas áreas de atuação na sociedade, agora não mais delimitadas pelo regime do padroado. A criação de novos organismos dentro do ambiente religioso e as novas divisões territoriais culminarão numa Igreja atuante em localidades tidas até então como remotas, cujos efeitos serão apreciados na região estudada.

Mostraremos os percursos históricos vivenciados pelas paróquias da atual Diocese de Limeira em sua consolidação e crescimento, especialmente os problemas ocasionados com a separação entre a Igreja e o Estado, além das dificuldades dos padres para consolidar as paróquias frente a realidades desafiadoras.

Trataremos das vicissitudes dos edifícios religiosos ao longo dos anos ${ }^{1}$, cujo arcabouço era frequentemente reestruturado visando sua ampliação, dada a necessidade de acomodar o crescente número de fiéis; ou seu embelezamento, já que se considerava que as melhorias efetuadas nestes símbolos identitários da cidade evidenciavam o progresso local.

\section{1 - O PROTAGONISMO DA IGREJA NA SOCIEDADE}

Com a proclamação da República e o consecutivo fim do padroado, a Igreja passou a se

1 Serão apresentados os percursos históricos das igrejas e seus respectivos templos, desde de suas construções como capela, até o início das ações (reuniões e projetos) que culminaram nas reconstruções em neocolonial na metade do século XX, que serão apresentadas no capítulo 3. 
comportar de maneira diferente em relação à sociedade. Seus ideais mudaram e sua forma de agir e de difundir seus ensinamentos, preceitos e dogmas passaram por alterações com intuito de acomodar a Igreja na nova forma de governo. Os desafios, e também as vantagens, da Igreja na sociedade republicana eram outros. Agora a Igreja não possuía mais o apoio integral do governo, não diretamente, mas podia agir livremente em suas nomeações e na difusão dos valores religiosos, consolidando-se assim como uma instituição prestigiada e influente dentro da sociedade, atuando como formadora de opinião e controle das massas.

A inquietação e descontentamento de padres e bispos vinculados ao ultramontanismo com o Governo Imperial vinham desde a metade do século XIX, questionando as dificuldades enfrentadas pelos prelados em exercer o múnus ${ }^{2}$ presbiteral e episcopal, devido às imposições do governo. Segundo Wellington Teodoro da Silva (2009), a separação entre a Igreja e do Estado soará como um ato auspicioso, uma liberdade para o catolicismo num momento em que buscava voltar sua disciplina para Roma, pois, "com a queda do Império, cessa o padroado, que oprimia a Igreja"3.

Com a separação entre o governo instituído e a Igreja na República, o processo ultramontano vivenciado pela Igreja ganhou forças e resultou em uma fervorosa a proximação e romanização da Igreja, além de uma atuação junto à sociedade de uma maneira diversa da experimentada até o momento.

A mudança do regime de governo brasileiro era também uma oportunidade de reforma e consolidação de uma nova imagem para a Igreja, uma limpeza de seus velhos costumes; agora, em qualquer conflito entre Estado e Igreja, a questão religiosa deveria estar acima da questão política, diferente do que acontecia anteriormente. A defesa da Igreja e de seus preceitos diante do Estado criou uma Igreja militante de si mesma que perdurou durante toda a primeira metade do século XX (SILVA, 2009, p.543).

Apesar de não ter mais o apoio oficial do Estado, a Igreja continuava a crescer exponencialmente. A mesma tinha interesse em que o Estado reconhecesse o país como sendo católico (SILVA, 2009, p.541), não mais como religião oficial, mas sim devido ao grande número de fiéis adeptos da fé católica o que garantia sua hegemonia perante as outras religiões. A população que se dizia católica vinha crescendo significativamente, em parte

2 Termo utilizado para referir-se às obrigações e atividades determinadas ao clero, a depender de sua hierarquia.

3 Apesar de se beneficiar da exclusividade de atuação e dos auxílios financeiros, o padroado limitava as ações da Igreja. Como já apontado, a mesma atuava mais como um órgão público de Estado, do que como Igreja, fazendo com que os ideais de evangelização e difusão dos sacramentos ficassem em segundo plano, frente as necessidades do governo. Com o fim do padroado, a Igreja, que já estava consolidada e amplamente instalada, passa a trabalhar apenas em causa própria, sem interferências de assuntos que em tese, não Ihe competia (VILLAÇA, apud. SILVA, 2009, p.543). 
devido à imposição religiosa do período Imperial, cujos efeitos ainda eram expressivos, e em parte como resultado das imigrações empreendidas pelo Governo a partir do último quartel do século XIX.

No caso de São Paulo, a chegada constante e maciça de imigrantes italianos para o manejo da lavoura fortaleceu o catolicismo. Os católicos italianos eram fiéis aos dogmas e preceitos da Igreja, e vivenciavam a fé com rigor. Segundo dados do Anuário Estatístico do IBGE, entre 1880 e 1949 chegaram ao Brasil aproximadamente 1.288.454 italianos (IBGE, 1950, p.55). É válido destacar que além dos Italianos, outras levas de imigrantes também professavam a fé católica, como espanhóis e portugueses, cujas tradições e costumes também colaboraram na expansão e na consolidação do catolicismo no território brasileiro. Além disso, muitos imigrantes que vinham de países de origem protestante, acabavam se convertendo ao catolicismo, devido à forte influência exercida pela Igreja e através de casamentos realizados com católicos, já que a conversão era necessária para a validação do sacramento religioso com disparidade de culto.

O número de católicos disparou junto com o crescimento da população e das cidades brasileiras. Em 1907 existiam no Brasil 1.957 paróquias, sendo 235 no estado de São Paulo, número que dobraria 40 anos depois, quando o Brasil contaria com 3.038 paróquias e São Paulo, com 565 (IBGE, 1912, p.25). Na metade do século XX, o número de católicos atingiu uma marca aproximada de 39.177.880 fiéis.

Esta Igreja fortalecida e bem estruturada do século XX irá acompanhar o crescimento do país e trabalhar em abordagens antes não habituais. Na década de 1920, a Igreja e o Estado perceberão um alinhamento de interesses e ideais, que resultou num processo de aproximação, conforme aponta Silva (2009):

O Estado se beneficiaria do grande poder legitimador do catolicismo, e este, por sua vez, utilizaria recursos e estruturas do Estado para a efetivação de seus projetos eclesiásticos (SILVA, 2009, p.543).

Até então, a Igreja, que estava bem consolidada em seu organismo religioso, suas paróquias e em seus eventos religiosos, não supria a demanda de uma religião atuante em questões políticas e que desejava colaborar nas decisões incisivas para o desenvolvimento da nação. Do processo de renovação vivenciado pela Igreja e da nova organização da sociedade, surgirá uma Igreja mais atuante, para além das questões religiosas. Uma nova visão e uma frente de trabalho divergentes das realizadas até então, permitirão que a Igreja assumisse funções que antes não lhe eram permitidas, mas que no seu entendimento, faziam parte do seu corpo disciplinar de cumprimento das ações do Evangelho e de assistencialismo aos pobres (SILVA, 2009, p.545). 
A militância religiosa, cujo cerne se encontra nos princípios ultramontanos, propiciará o surgimento de padres e bispos ${ }^{4}$ interessados em consolidar uma Igreja de maior protagonismo na sociedade, que ocasionará o nascimento das pastorais sociais e ações internas ligadas aos movimentos políticos. Mesmo sem estar ligada a um partido oficial, a Igreja sempre buscou participar da cena política, numa relação direta de interesses e apoio para determinados candidatos (SILVA, 2009, p, 555).

As atividades católicas, que até então se limitavam aos serviços religiosos, missas, novenas e orações, passaram a incluir outras iniciativas, cujos fins não eram estritamente ligados à oração e ao exercício dos preceitos religiosos. As Igrejas, que até então eram compostas por Irmandades, Confrarias e afins, passaram a ter também as Conferências Vicentinas, Congregações Marianas, Pias União Filhas de Maria e as ligas católicas, que, através de encontros e reuniões formaram grupos de trabalhos e de oração, fomentando desta forma uma maior participação da sociedade na Igreja e da Igreja na sociedade (SILVA, 2009, p, 551). Deste modo, além de irem à Igreja para os ritos e missas, as pessoas se dirigiam para estudar os documentos da Igreja, fazer reuniões e preparar e arrecadar auxílios para os pobres, fazendo com que a Igreja ocupasse uma posição central na vida dos cidadãos, ou seja, as atividades religiosas "variadas" ocupavam uma boa parte do tempo e da vida das pessoas.

\section{A CRIAÇÃO DE NOVAS PARÓQUIAS E A DIVISÃO DA DIOCESE - UMA IGREJA MAIS PRESENTE}

O crescimento do número de católicos era bem visto e apreciado pela Igreja, porém, suas lideranças encontravam dificuldades para administrar o grande número de paróquias e estabelecer uma Igreja presente em todos os cantos da diocese. Os extensos territórios eclesiásticos estavam concentrados na mão de um único bispo, que deveria gerir e administrar as paróquias, os padres, além de outros organismos ligados à Igreja, como conventos e mosteiros.

O clero em geral apresentava problemas oriundos da má formação, ainda muito incipiente e custosa para a Diocese. Os padres eram em número insuficiente para conduzir o povo, principalmente em realidades mais distantes e extremas, com tantas paroquias e capelas dispostas no interior dos estados (MENDONÇA, 2003, p.149). No estado de São Paulo, a Diocese de São Paulo, criada em 6 de dezembro de 1745 pelo Papa Bento XIV, era a única existente até 1908, sendo responsável pelas 235 paróquias então existentes no território

4 Destaca-se nesse segmento o Cardeal Dom Sebastião Leme, importante defensor do uso do Neocolonial nos edifícios religiosos. Seu protagonismo acerca da presença da Igreja Católica na sociedade gerou frutos efetivos, como a criação da Liga Eleitoral Católica (LEC) e o Centro Dom Vital, importante organismo de estudo e difusão da intelectualidade católica. Veremos mais sobre a atuação do Cardeal Leme no capitulo 3. 
paulista. A falta de clero para suprir a demanda, a distância de algumas paróquias em relação à sede do bispado e o crescimento do número de paróquias da própria capital dificultavam os trabalhos do bispo diocesano, que se preocupava cada vez mais com a ausência de assistência religiosa em algumas localidades.

A implantação de novas paróquias consolidava os planos da Igreja de se difundir e se estabelecer por todo o território. Porém, as longas distâncias a serem percorridas em visitas pastorais $^{5}$, e a demora na criação de novas dioceses dificultavam as atividades pastorais e espirituais do prelado paulistano. Somente em 07 de junho de 1908 a Diocese de São Paulo sofreria seu primeiro desmembramento territorial: serão criadas as Dioceses de:

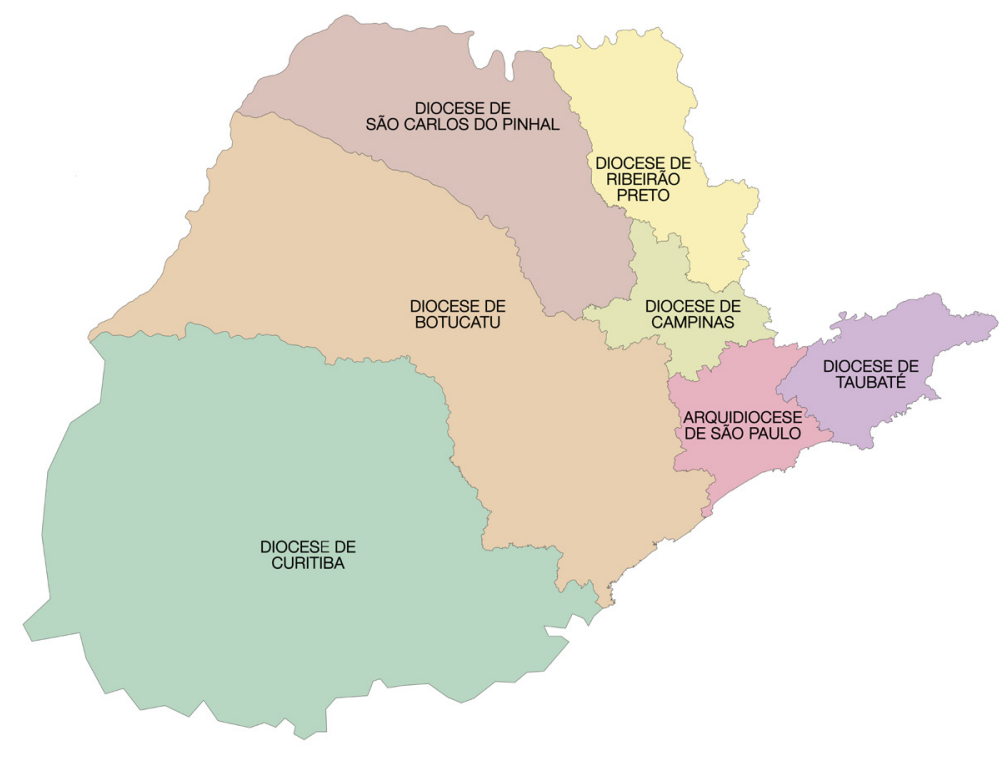

Campinas, com 33 paróquias; Taubaté, com 40; Botucatu, com 52; São Carlos, com 29 e Ribeirão Preto, com 36. Nesta mesma ocasião, a Diocese de São Paulo, com 45 paróquias, foi elevada à condição de Arquidiocese, gerando dessa forma a Província Eclesiástica de São Paulo6 .

Figura 27: Província Eclesiástica de São Paulo em 1908. Fonte: Elaborado pelo autor. Baseado em: Arquidiocese de Campinas.

No que se refere à região estudada, a criação da Diocese de Campinas, à qual ficou pertencendo todo o território da atual Diocese de Limeira, favoreceu e dinamizou os trabalhos que eram desenvolvidos nas paróquias da região. A presença contínua do bispo diocesano, e um maior rigor e controle da cúria sobre os trabalhos dos párocos, possibilitaram uma expansão da fé católica nas cidades onde antigamente existia apenas uma paróquia, e que as vezes ficava

\footnotetext{
5 As visitas pastorais eram realizadas pelo bispo diocesano, ou por um padre por ele nomeado, às paróquias. O intuito da visita era de acompanhar os trabalhos que vinham sendo desenvolvidos pelo pároco e dispensar os sacramentos ao povo. A visita, que geralmente acontecia de 3 em 3 anos, era marcada por pompas e solenidades, dado que era difícil a presença do bispo diocesano nas paróquias, principalmente as mais afastadas da sede do bispado. Entre os ritos e cerimônias realizadas, o bispo visitava as autoridades locais, as irmandades, hospitais e outras instituições, além de realizar uma vistoria no edifício da igreja e nos livros de registro. No final, a visita gerava um relatório que era transcrito no livro tombo e anexado ao arquivo da Cúria Diocesana.

$6 \quad$ Província Eclesiástica é uma forma de agrupamento de dioceses pela Igreja Católica. Uma província eclesiástica, possui uma arquidiocese metropolitana e várias dioceses, cuja função é dinamizar os trabalhos da região e estabelecer normas sacramentais. Na criação da Província Eclesiástica de São Paulo, além das dioceses criadas no território paulista, foi anexada a Diocese de Curitiba que abrangia todo o território paranaense.
} 
longos períodos sem a presença de um padre.

A instalação da Diocese de Campinas favoreceu ainda em um maior controle na formação dos padres, na criação das paróquias e na formação do povo católico. As cidades passaram a receber congregações religiosas a pedido do bispo diocesano, com vistas a colaborar na atividade evangelizadora, e na intenção de ajudar a desenvolver as localidades no suprimento de equipamentos e atividades essenciais para a promoção da vida. Expandemse neste momento os equipamentos religiosos voltados à vida civil, como os colégios católicos, hospitais, orfanatos, creches e asilos, além da criação das primeiras universidades confessionais, que formalizaram a atuação da Igreja no ambiente científico. Todas essas infraestruturas e suas obras sociais, bem como as paróquias, eram mantidas pelas dioceses e pelas congregações religiosas, através de dízimos e ofertas oriundos do povo.

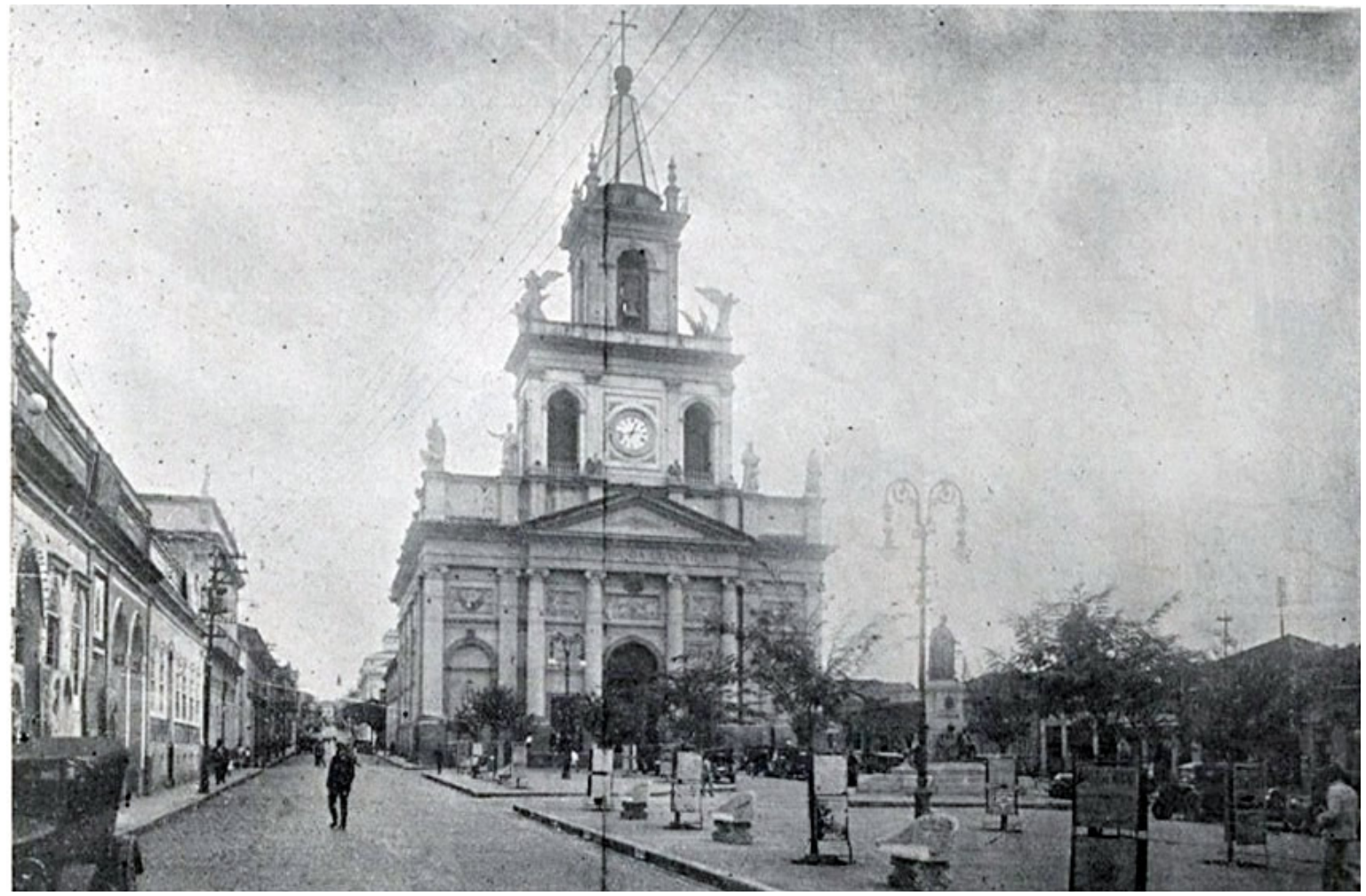

Figura 28: Catedral Imaculada Conceição de Campinas em 1932, sede da Diocese de Campinas. Fonte: Campinas virtual.

As 33 paróquias que compunham a Diocese de Campinas estavam espalhadas por um vasto território, sendo a maior parte delas na cidade sede do bispado. As paróquias maiores, isto é, presentes nas cidades mais antigas e estabilizadas financeiramente, eram ocupadas pelos padres com mais experiência e que geralmente tinham algum cargo administrativo ou honorífico dentro da Cúria Diocesana, além de comporem o Cabido Diocesano 7 . A dinâmica

$7 \quad$ O cabido é um conselho de estatuto e hierarquia própria formado pelos cônegos, cuja função principal é colaborar na administração da liturgia na Catedral e das igrejas correspondentes. Antigamente, o cabido 
administrativa da diocese era muito semelhante à atual, exceto pelo número reduzido de padres, que frequentemente tinham que atender demandas de várias paróquias, acarretando prejuízos no atendimento regular aos fiéis. A instabilidade dos párocos e a mudança constante no provimento das paróquias ocasionava sérios problemas administrativos e de desenvolvimento da comunidade, cujo ônus reverberava constantemente na própria materialidade do edifício da igreja matriz, através de reformas e reconstruções inacabadas como será apresentado no item a seguir.

\section{2 - AS IGREJAS CRESCEM E AS PARÓQUIAS SE ESTABELECEM}

No processo de constituição das freguesias (ou paróquias), o edifício da igreja sempre acompanhou o crescimento da localidade e o status a ele conferido. As cidades que tiveram suas paróquias criadas no período Imperial tiveram uma experiência diferente das paróquias criadas na República, que já não podiam contar com o suporte financeiro da municipalidade para a construção e manutenção do templo. No entanto, outros agentes passaram a contribuir para a construção e a manutenção das igrejas, por vezes movidos por interesses alheios ao âmbito religioso.

O edifício da igreja, símbolo da comunidade e espaço de variadas atividades sociais, será objeto de constantes alterações com vistas à sua adequação ao crescimento das cidades. Variados fatores irão colaborar de formas distintas nas alterações e reformas incidentes sobre as paróquias e seus templos. O aumento do número de católicos e o desejo de melhorias, serão, em inúmeros casos, fatores determinantes para tais empreitadas. Uma Igreja inserida e protagonista na sociedade intensificou as interações intrínsecas entre a cidade, a população e sua paróquia, como será mostrado a seguir.

\section{A PARÓQUIA NOSSA SENHORA DAS DORES DE LIMEIRA}

Como apontado no capítulo 01 (p.37), a Capela Nossa Senhora das Dores de Limeira, que havia sido construída no início da ocupação da região, não sofreu reformas e ampliações quando se instalou a Freguesia em 1831. Pouco se sabe da arquitetura desta primitiva capela, além de que possuía duas águas e uma torre lateral. A partir de 1844, quando a Freguesia de Nossa Senhora das Dores do Sertão do Tatuibi foi elevada à Vila de Limeira, a Câmara empreende esforços junto ao Governo Provincial para obter recursos para a construção da nova matriz. É válido destacar que neste período- devido à relação entre a Igreja e o Governo Imperial - fazia parte das competências da Câmara cuidar do edifício da Matriz e conseguir

também colaborava com o bispo diocesano na administração das dioceses, como conselheiros do prelado. No entanto, esta questão revista no Concílio Ecumênico Vaticano II, que transferiu essa obrigação ao Colégio de Consultores e Conselho de Presbíteros. 
junto ao Governo Provincial proventos para sua conservação e melhoria. Em 17 de janeiro de 1845 a Câmara envia um ofício ao Governo Provincial justificando a necessidade do pleito. Nesta solicitação é destacado o parecer do chefe da terceira sessão dos engenheiros da Província, José Porfirio, indicando que a construção estava propícia a "cahir e tendo os fracos esteios arruinados pela base desbroando-se as paredes e a torre pendida para fora da linha orisontal" (CARITÁ, 1998, p.78), o que comprometia o fornecimento dos serviços religiosos à vila, sendo urgente a sua reforma. Entretanto, mesmo descrevendo a pequena proporção e frágil estrutura da construção, o pedido foi negado pelo Governo Provincial.

Durante anos, a Câmara de Limeira, juntamente com a Fábrica da Matriz, realizou campanhas de captação de recursos para as obras. Em 10 de janeiro de 1848, a Lei provincial no 14 regulamentou a cobrança de impostos para financiar a construção da nova Matriz de Limeira. Os moradores deveriam contribuir com este tributo sob o risco de serem intimados judicialmente caso não o pagassem. Contudo, devido a entraves políticos, a lei nunca entrou em vigor, e somente pequenos reparos foram feitos de acordo com as necessidades. Constam das atas da câmara diversos pedidos e solicitações do pároco e do fabriqueiro para a Igreja Matriz, dentre eles: conserto do reboco de paredes e seu branqueamento (caiação), confecção de objetos de madeira para o interior (cadeiras e bancos), construção de dois púlpitos e consertos no sino.

Mesmo em meio a disputas políticas o vigário José Gomes Pereira da Silva procurava levantar recursos junto aos cidadãos abastados, iniciando a discussão sobre a demarcação do terreno onde se deveria construir a nova matriz, assunto que foi amplamente discutido nas sessões da câmara. Todavia, como não se conseguiam as condições necessárias para a nova empreitada, em 1852, o pároco arrecadou importante valor junto aos moradores e ao Governo Provincial, destinado à execução de melhorias no antigo edifício. O reverendo providenciou a substituição do madeiramento deteriorado, utilizando madeira de lei, além de forrar a capela mor e assoalhar o corpo da Igreja, após aumentá-la 70 palmos de comprimento, colocar novos sinos e consertar os antigos (BUSCH, 2007, p.237).

Em 1854, uma infestação de formigas na estrutura de terra das taipas da igreja fez com que a Câmara autorizasse o fabriqueiro a fazer as 'despesas necessárias para liquidar com a praga" que colocava em risco a Igreja Matriz. No ano seguinte, o edifício foi novamente ampliado, recebendo acréscimos na sua lateral para a construção de um consistório para o Santíssimo Sacramento (CARITÁ, 1998, p.103).

\section{A CONSTRUÇÃO DA CAPELA DE NOSSA SENHORA DA BOA MORTE E ASSUMPÇÃO}

No ano de 1856, um grupo de senhores abastados e importantes figuras públicas da vila passaram a se reunir na Igreja Matriz e criaram a Irmandade Nossa Senhora da Boa Morte 
e Assumpção, da qual faziam parte José Ferraz de Campos, o Barão de Cascalho, e Bento Manoel de Barros, o Barão de Campinas, o mesmo que ajudara a construir a primitiva capela de Nossa Senhora das Dores em 1826, como mostrado no capítulo 1 (CARITÁ, 1998, p.106).

Em 1858, o Barão de Campinas comprou um terreno próximo da igreja matriz - apenas duas quadras acima - para que a Irmandade pudesse construir sua igreja própria, para cuja edificação rapidamente obtiveram o aval da Diocese de São Paulo, devido ao prestígio de seus membros. Neste mesmo ano, as obras se iniciaram, tendo a capela mor como ponto de partida. A construção foi financiada pelos membros da Irmandade, que cederam escravos para a edificação do templo. A técnica empregada foi a da taipa de pilão, utilizada em edifícios mais nobres e de grande porte. As paredes de $90 \mathrm{~cm}$ de espessura causaram certo estranhamento uma vez que a Igreja Matriz possuía delgadas paredes de taipa de mão (ROSADA, 2010, p.131).

A Irmandade, que construiu a capela-mor, contou com a ajuda do Barão de Cascalho para a construção das paredes de taipa da nave e a cobertura. A conclusão do templo esteve a cargo de outro benfeitor, o Barão de Campinas, que construiu as duas torres de tijolos e executou o acabamento (CARITÁ, 1998, p.04).

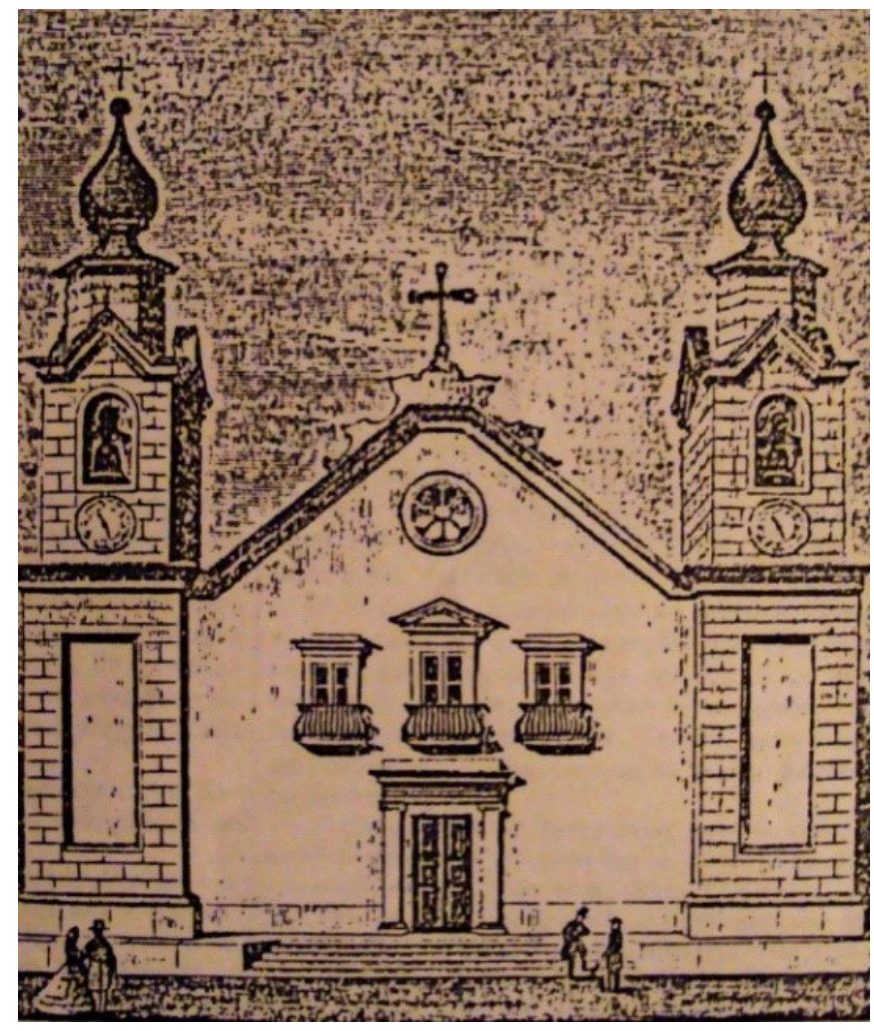

O projeto inicial foi concebido pelo vereador da cidade e membro da Irmandade, Francisco José de Araújo Lima. Quando a capela mor já estava coberta e as paredes do corpo da igreja estavam em andamento, o Barão de Campinas contratou o arquiteto florentino Aurélio Civatti para reformular partes do projeto que ainda não haviam sido executadas, como a fachada, e realizar os entalhes e altares da igreja.

Figura 27: Fachada da Igreja da Boa Morte no desenho de Júlio Arouche mostrando o projeto do arquiteto florentino Aurélio Civatti.Fonte: AROUCHE apud ROSADA, 2010, p.132.

O trabalho executado na Igreja da Boa Morte era de grande destaque, chegando inclusive a ser noticiada em 1866 no jornal lusitano "O Archivo Pittoresco", de Lisboa, que evidencia o prestígio dos membros da Irmandade: 
Vamos admirar a egreja de Nossa Senhora da Boa Morte, que a estampa representa [fig.7]. Este modesto templo foi começado ha poucos anos pela irmandade da sua invocação. Pouco depois, o comendador José Ferraz de Campos, coronel reformado da Guarda Nacional, tomou para si esse honroso serviço, e levantou á sua custa todas as paredes do templo, que são de taipa, gastando não poucos contos de réis. Estava a obra n'este ponto quando o cidadão Bento Manoel de Barros, um dos primitivos fundadores da cidade, se encarregou de concluir o edifício á sua custa, fazendo tudo quanto é de madeira, e as torres, pintura, doirados, etc. Os trabalhos não foram riscados por um engenheiro, por isso são desculpáveis os erros que n'elles se notam, apesar de serem dirigidos pelo cidadão F.J. [Francisco José] de Araújo Lima, cujo zelo e actividade são inexcedíveis. Mais tarde, o distinto artista italiano Aurélio Civatti, não só tem enriquecido a obra com primores de talha, mas tem remediado, tanto quanto possível, os defeitos acima mencionados. As torres são desenho do mesmo artista, que dizem ficar promptas no decurso do corrente ano, assim como a obra no interior (AROUCHE apud. ROSADA, 2010, p.132).

Em 1867, a Igreja de Nossa Senhora da Boa Morte é finalmente inaugurada com grande júbilo da população local e com solenes festividades encomendadas pelos membros da Irmandade. Nesta ocasião, o Barão de Campinas - maior empreendedor na edificação do templo - lavra em cartório uma ata doando o terreno da igreja à Irmandade, além de alfaias e imagens.

Dois anos após a inauguração de sua igreja, o papa Pio IX elevou a Irmandade da Boa Morte ao grau de Confraria, o que Ihe conferia diversos direitos. Neste momento, devido à situação precária em que se encontrava a Igreja Matriz de Limeira, foi feito um pedido junto ao governo diocesano para transferir a Matriz da paróquia para a Capela de Nossa Senhora da Boa Morte, pedido este que foi negado pela diocese (ROSADA, 2010, p.134).

\section{A PRIMEIRA RECONSTRUÇÃO DA MATRIZ NOSSA SENHORA DAS DORES}

Com o passar do tempo e o crescimento da cidade - parte deste impulsionada pela chegada de imigrantes patrocinada pelo Senador Vergueiro, através de sua empresa Vergueiro \& Cia", para a substituição do trabalho escravo no engenho Ibicaba- o edifício da Igreja Matriz Nossa Senhora das Dores se tornou pequeno para acomodar os fiéis nas celebrações e continuou a gerar mal-estar na cidade devido a sua pobre arquitetura, contrastante com a suntuosa nova Capela de Nossa Senhora da Boa Morte. Conforme consta nos registros do livro tombo,a igreja matriz: "era uma igreja tosca e de madeira barroteada. Era chocante então ver a Igreja Matriz, a que deveria ser a primeira em arte e beleza, muito inferior a filial" (TOMBO II. NSD. p.106).

Discussões são realizadas novamente na Câmara de Limeira para a construção de uma nova

8 Sobre as imigrações financiadas pela empresa Vergueiro \& Cia ver: BALDIN, Adriane. Tijolo sobre tijolo: os alemães que construíram São Paulo. Curitiba, Editora Prismas, 2014. 
igreja matriz, uma vez que esta era o símbolo da vila e da elite local e deveria portar boa arquitetura para mostrar a pujança das terras limeirenses; porém, enquanto nada se resolvia sobre uma nova construção, as atas da Câmara revelam o cuidado e a manutenção constante - necessários devido à fragilidade da estrutura- no edifício da matriz pelo fabriqueiro, com solicitações de reparos nos madeiramentos e a caiação das paredes (CARITÁ, 1998. p.106).

Em 1857, a câmara nomeou uma comissão para cuidar do projeto e das obras da nova matriz, porém, devido a dificuldades financeiras, esta comissão não chegou a trabalhar. 0 então vereador Justino Franco assume em 1866 a missão de procurar viabilizar a construção da nova igreja matriz. Para tanto, estudou o modelo de regulamentação de obras aplicado na construção da nova matriz de Rio Claro, além do código de posturas utilizado em Amparo, o qual pediu que fosse copiado e executado em Limeira (CARITÁ, 1998, p.115).

Neste período, as turbulências políticas na Câmara de Limeira continuam dificultando as obras da nova matriz. Em 16 de abril de 1867 foi criado um imposto sobre a produção de alguns produtos rurais, como o café, o algodão, o açúcar e a aguardente, cujos valores deveriam compor um fundo pró-obras da Igreja Matriz. Porém, por entraves políticos, um grupo de vereadores propõe que os fundos fossem aplicados na criação de uma Santa Casa de Misericórdia e de uma Casa de Socorro aos Lázaros, o que conseguem em uma votação combinada, deixando o vereador Franco sem fundos para edificar a nova igreja. O vereador tentou recorrer à Assembleia Provincial, mas não obteve sucesso.

Nas discussões referentes à construção da nova matriz e a articulação política por trás desta, é interessante notar que a relação Igreja-Estado, que deveria facilitar a construção destes edifícios, acabava por atrapalhar. No caso da Boa Morte, de origem particular, a construção se deu de maneira muito mais rápida.

Em 26 de novembro de 1871, após pequenos reparos na já desgastada matriz, o Barão de Campinas novamente intervém em favor da igreja, oferecendo à Câmara os recursos necessários para reconstruir a matriz da cidade.

[...] e ameaçando grande ruina a mesma Matriz, vem respeitosamente o suppe oferecer reconstruir com toda a solidez e aceio as espenças suas e não podendo fazer sem consentimento para esse fim [...] O Suppe é um dos primeiros desta cidade, para aqui veio residir quando isto (era) sertão, aqui exgotou sua mocidade nos rudes trabalhos da lavoura hoje velho só viza os gosos além tumulo e como bom catholico não deseja ver sua Matriz por terra e tendo em vista que ella fique ad gloriosam rei memoria sugeita-se a fazer com toda a solidez e limpeza a já dita reconstrução e espera que esta Camara como zeladora de seu município de bom grado aceitará o oferecimento do suppeacressendo que esta Camara deve estar seinte do mao estado financeiro da nossa pronvicia e que não pode fazer despesa alguma sem o grande sacrifício, razão pela qual deve esta câmara aceitar a proposição do suplicante atendendo o lastimoso estado em que se acha a dita matriz necessitando de prompto reparos afim de termos o desgosto de vermos 
desaparecer a primeira igreja fundada neste lugar [...] (LIMEIRA, 1880, p.56V).

Com a aprovação pela Câmara da proposta do Barão de Campinas, a sede paroquial passou para a Igreja da Boa Morte em 1871, para que fossem dados os devidos procedimentos para as obras da nova matriz. Em 28 de janeiro de 1872, a Câmara manda a comissão de obras da nova matriz marcar o terreno onde ela deveria ser edificada, atrás da primitiva, fazendo costas com a rua do Comércio (atual Rua Doutor Trajano). Com a idade avançada e bastante doente, o Barão de Campinas entrega a missão de edificar e concluir a igreja a seu filho, Pedro Antônio Barros e novamente ao arquiteto Aurélio Civatti, cujo contrato foi assinado na Câmara de Limeira em 03 de março de 1872. A pedra fundamental da nova Matriz Nossa Senhora das Dores foi colocada no dia 07 de abril de 1872, em cerimônia de grande festejo e júbilo na cidade. No final do mesmo mês iniciou-se a construção do novo templo, em tijolo, argamassa e cal- um edifício de grandes proporções, com 28 metros de frente e 45 metros na sua lateral. Em 07 de dezembro do mesmo ano, quando a construção estava em andamento, falece seu maior benfeitor, o Barão de Campinas, deixando em testamento cem contos de réis a seu filho para a conclusão da edificação do templo.

O projeto de Civatti, que assumia linhas neoclássicas, apresentava frontão triangular e possuía duas torres em sua fachada, assim como a Capela da Boa Morte, além de galilé com três grandes arcos, correspondentes às três portas de entrada. Em sua planta é possível notar a presença de naves laterais, separadas por uma colunata. A Capela Mor e seu presbitério eram ladeados por duas capelas destinadas a devoções populares.

Figura 28: Construção da Matriz Nossa Senhora

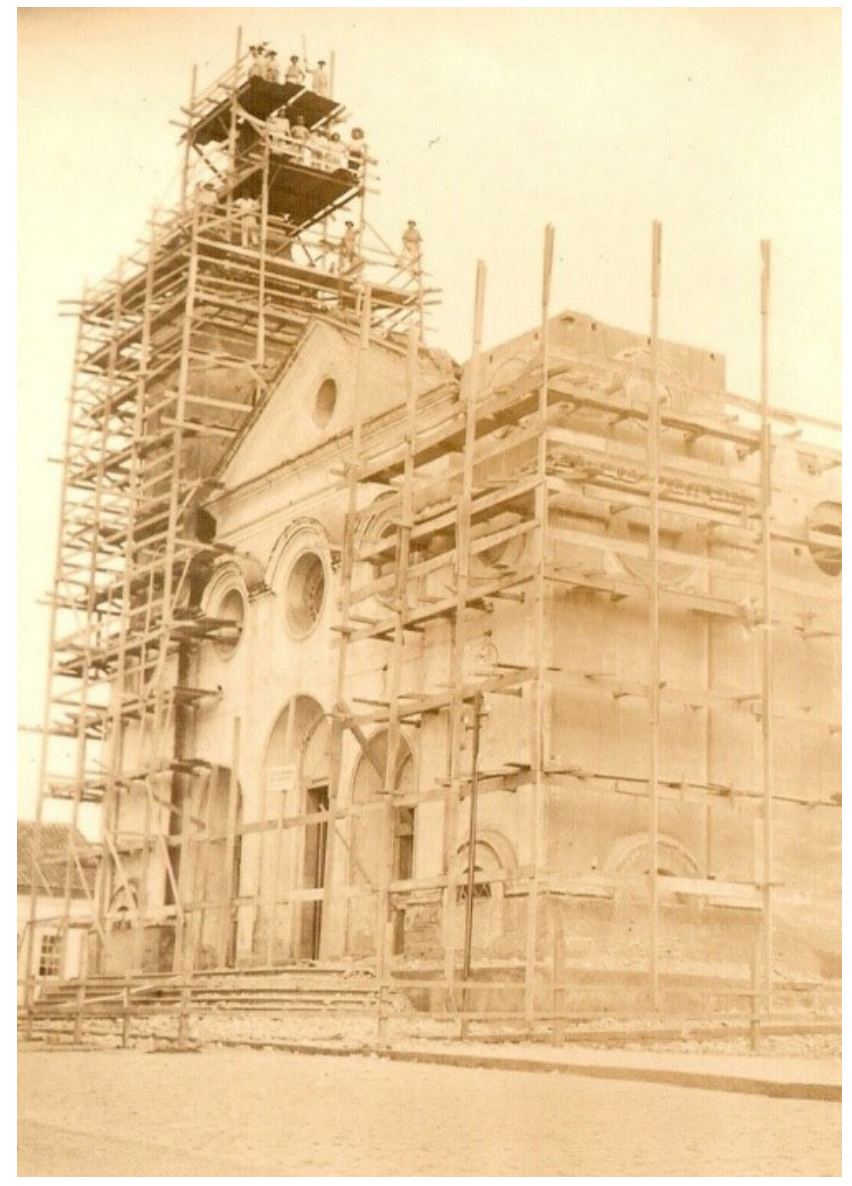
Catedral Nossa Senhora das Dores. 

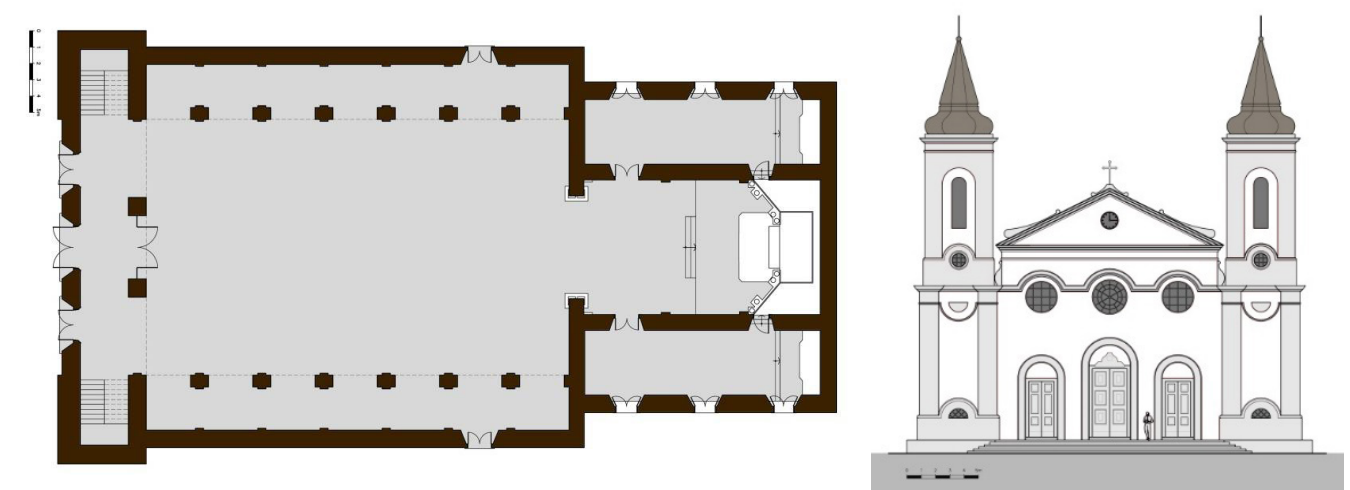

Figura 29: Planta e elevação da Igreja Matriz de 1876, projeto de Aurélio Civatti. Fonte: ROSADA, 2010, p.138.

A conclusão da construção da nova igreja se deu no ano de 1876. Na época, Limeira contava com 14.283 habitantes, sendo 3.059 escravos, 293 casas e 33 eleitores, segundo dados do censo provincial. Constam também deste censo, o número de olarias (7) e pedreiros (8) atuantes na vila (BUSCH, 2007, p.300). Muitos destes profissionais, de origem europeia, foram trazidos pelo Senador Vergueiro para trabalhar em sua fazenda, tendo sua viagem e estadia custeadas para serem pagas paulatinamente com o seu trabalho, o que durava de 6 a 10 anos. No entanto, alguns conseguiram quitar suas dívidas e sair com saldo suficiente para comprar pequena gleba de terra, montar pequena indústria de tijolos, oficina de ferreiro ou carpinteiro, ou mesmo instalar pequena casa de comércios (BALDIN, 2014, p. 88). Estes profissionais possivelmente colaboraram na construção da Igreja Matriz, tanto na execução, quanto no fornecimento de materiais, através das olarias.

Neste mesmo ano, a Paróquia Nossa Senhora das Dores, antes mesmo de ser inaugurada, recebeu no mês de janeiro a visita pastoral do bispo de São Paulo, que em seu relatório da visita, relata a suntuosidade e a beleza do novo templo que deveria servir a Matriz paroquial.

Tivemos ocasião de visitar a nova Matriz, que se está construindo, e notamos com a mais viva satisfação, que esse templo prestes a concluir-se é solidamente construído, vasto e bem ornado, tal como reclamão as circunstâncias do lugar e as necessidades da população (TOMBO II. NSD. p.130v).

Com a construção do novo edifício na parte superior do Largo da Matriz, foi abertura uma nova via de circulação - a atual Rua Barão de Campinas - cortando o antigo largo ao meio, e consolidando assim o tecido ortogonal da cidade. Neste mesmo ano, a Cúria de São Paulo autorizou a benção da nova igreja matriz e a sua inauguração, que devido à presença da Cia Paulista de Estrada de Ferro contou com cerca de 4000 pessoas vindas de Rio Claro e Campinas ${ }^{9}$. A cidade foi ornamentada para o acontecimento, sendo aberta a rua que ligava

$9 \quad$ Não há informações de como se deu a vinda dessas pessoas para a inauguração da Igreja Matriz. As fontes que relatam a vinda de pessoas de outras cidades não deixam claro se houve uma distribuição de passagens, como era comum na época, ou não. 
o Largo da Matriz à estação - atual rua Cunha Bastos -, conforme destacado no Jornal "A Província de São Paulo", de 13 de junho de 1876: "diz o Limeirense que deve inaugurar-se dia 8 de setembro próximo futuro a Igreja Matriz desta cidade, feita às expensas do Barão de Campinas e cujas obras tem sido dirigidas por seu filho, o Sr. Pedro de Barros. O novo edifício destinado ao culto da sublime religião, é vasto, espaçoso e talvez o mais elegante da província atualmente" (CARITÁ, 1998, p.129).

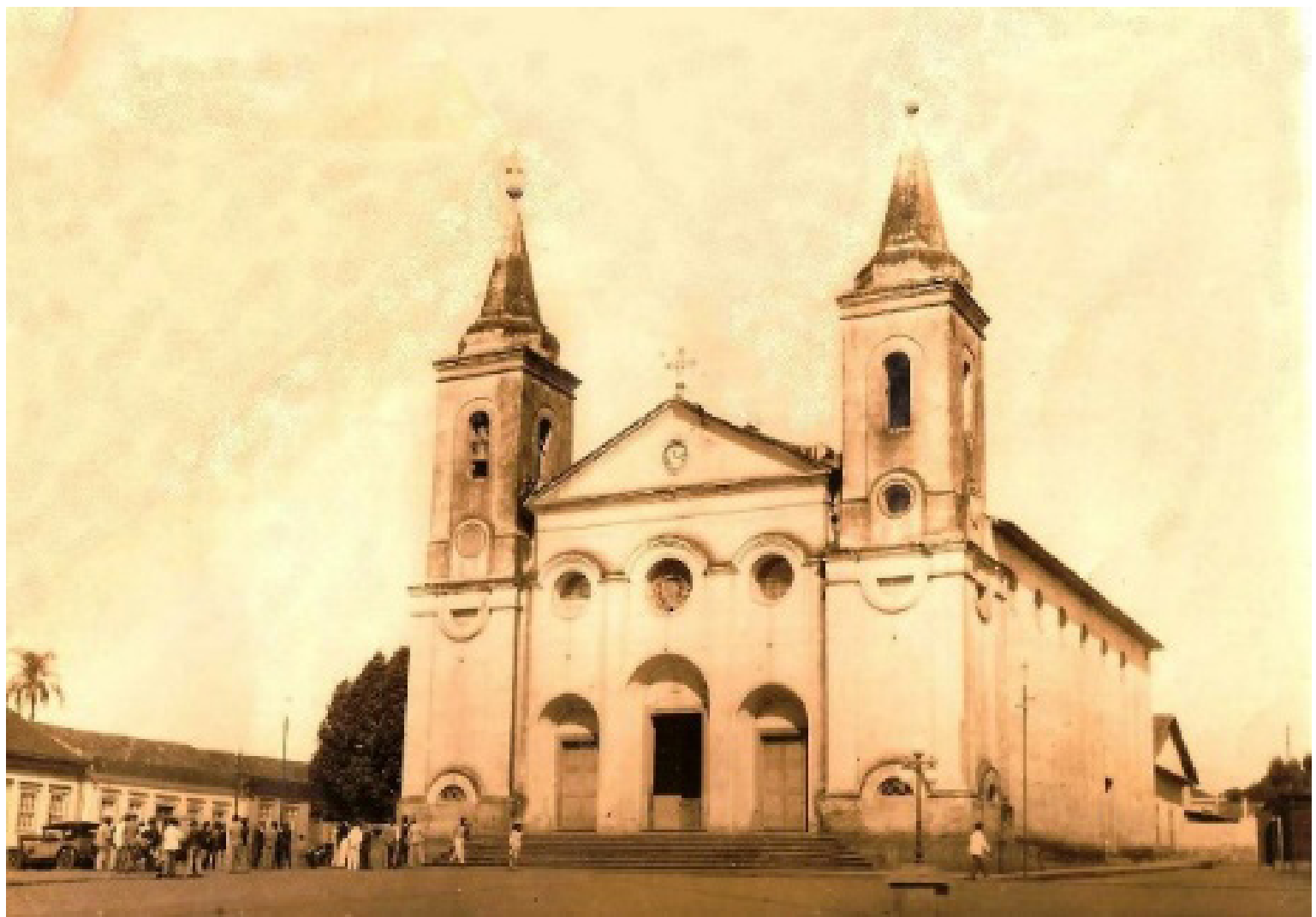

Figura 30: Igreja Matriz Nossa Senhora das Dores de Limeira no final do século XIX. Fonte: Acervo da Catedral Nossa Senhora das Dores.

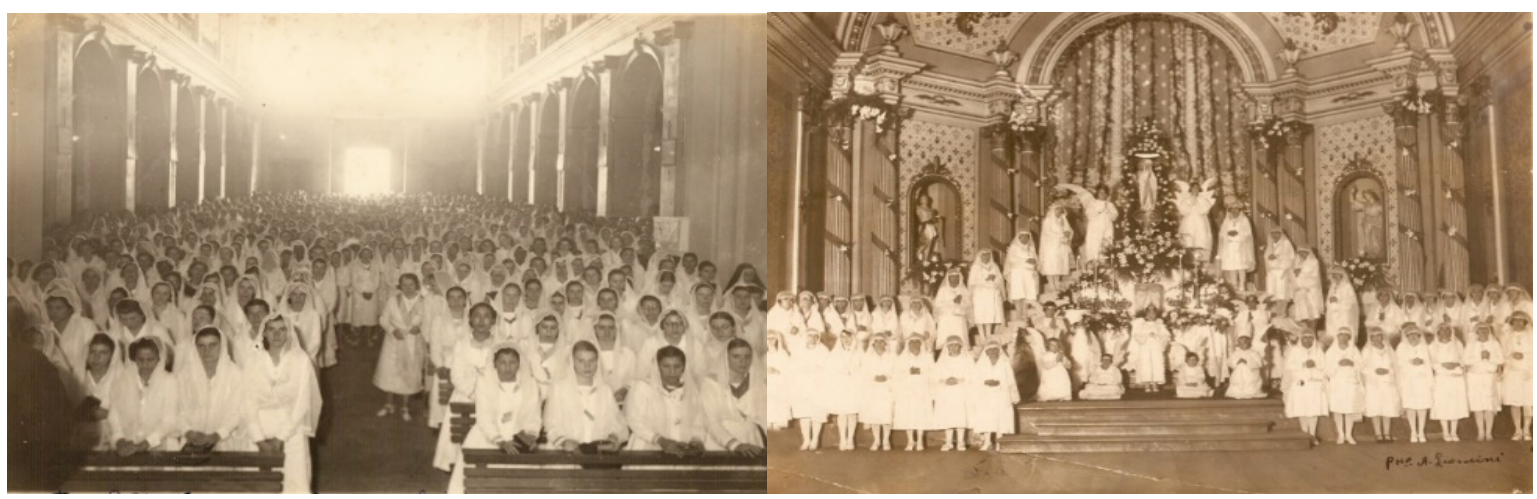

Figura 31: Imagens do interior da Igreja Matriz, onde é possível notar a semelhança com a Igreja da Boa Morte em suas talhas e altares, além da colunata lateral. Fonte: Acervo da Catedral Nossa Senhora das Dores. 
Segundo relatos da época, o edifício era marcante; os púlpitos em forma de concha, o trono, o altar mor, seus entalhes e florões - muito parecidos com o da Igreja da Boa morte - executados em madeira de cedro foram destacados pelo jornalista Candido José Soares, em seu histórico sobre a Igreja Matriz, além de sua estrutura de grossas paredes de tijolos, cimento e cal, que impressionavam a todos (CARITÁ, 1998, p.131).

\section{AS TERRAS PATRIMONIAIS DE LIMEIRA}

As terras patrimoniais de Limeira, que haviam sido concedidas por doação do Capitão Luiz Manoel Cunha Bastos à Nossa Senhora das Dores na construção da capela em 1826 (capítulo 01, p. 37), representaram um verdadeiro imbróglio na administração pública com o passar dos anos, principalmente no segundo império, próximo ao fim do regime do padroado.

Em 1844, quando a freguesia foi elevada ao grau de vila, a recém instalada Câmara não tinha onde tirar proventos para promover a edilidade pública, pois as terras comunais do rocio, que eram destinadas às suas atividades, não existiam mais, conforme apontado também no capítulo 01 (p.42). Desta forma, todo o território onde estava assentada a Vila de Limeira era aforada pela fábrica da Matriz, como Ihe era de direito.

No entanto, a Câmara não se dava por vencida e buscava meios de se apropriar da terra para dela tirar seus proventos. O que acabou resultando em inúmeras tensões geradas entre os edis, o pároco e o fabriqueiro. A querela entre a Câmara e a Igreja na briga pela posse da terra se arrastaram pelos anos, com constantes pedidos da Câmara para que a Assembleia Provincial a autorizasse a vender as terras que eram do patrimônio religioso; as respostas sempre foram favoráveis à Igreja, respeitando desta forma o acordo firmado com o padroado ${ }^{10}$.

Após 5 tentativas frustradas ${ }^{11}$, em 26 de maio de 1873, a Câmara decidiu mudar de postura e acabou processando Nossa Senhora das Dores, a então proprietária das terras. Segundo aponta Rosada (2010), o resultado do processo é desconhecido até hoje, uma vez que o mesmo não foi encontrado. Contudo, o resultado parece novamente ter sido favorável à Igreja, pois um sexto pedido foi encaminhado à Assembleia Provincial em 1875, quando finalmente foi concedida a autorização para que a Câmara vendesse as terras pertencentes ao patrimônio doado por Cunha Bastos.

\section{AS PROPOSTAS DE RAMOS DE AZEVEDO PARA AS IGREJAS DE LIMEIRA}

Em 1876, a Capela da Boa Morte, que fora construída com técnica avançada e materiais

10 Para saber mais sobre o assunto ver: ROSADA, 2010, p.170.

11 Foram realizados pedidos de autorização para a venda das terras do patrimônio junto à Assembleia Provincial em: 1845, 1854, 1857, 1861 e 1867. (ROSADA, 2010, p.178). 
nobres para a época, começou a apresentar problemas, apenas 12 anos depois de sua conclusão. O edifício começou a dar sinais de recalque em sua fundação, principalmente na sua fachada principal, onde o frontispício e as duas torres ameaçavam ruir. No ano de 1880, o arquiteto Francisco de Paula Ramos de Azevedo elabora dois projetos de frontispício, um para a Igreja da Boa Morte e um para a Igreja Matriz. Ambos previam o encamisamento de tijolos ${ }^{12}$ sobre as estruturas já existentes e a construção de uma torre central, tal como o arquiteto realizara nas matrizes de Campinas e de Itu, além de acrescentar uma série de ornatos e elementos que reconfigurariam a fachada principal das mesmas, transformandoas em edifícios de arquitetura eclética. Os projetos, porém, não foram executados.
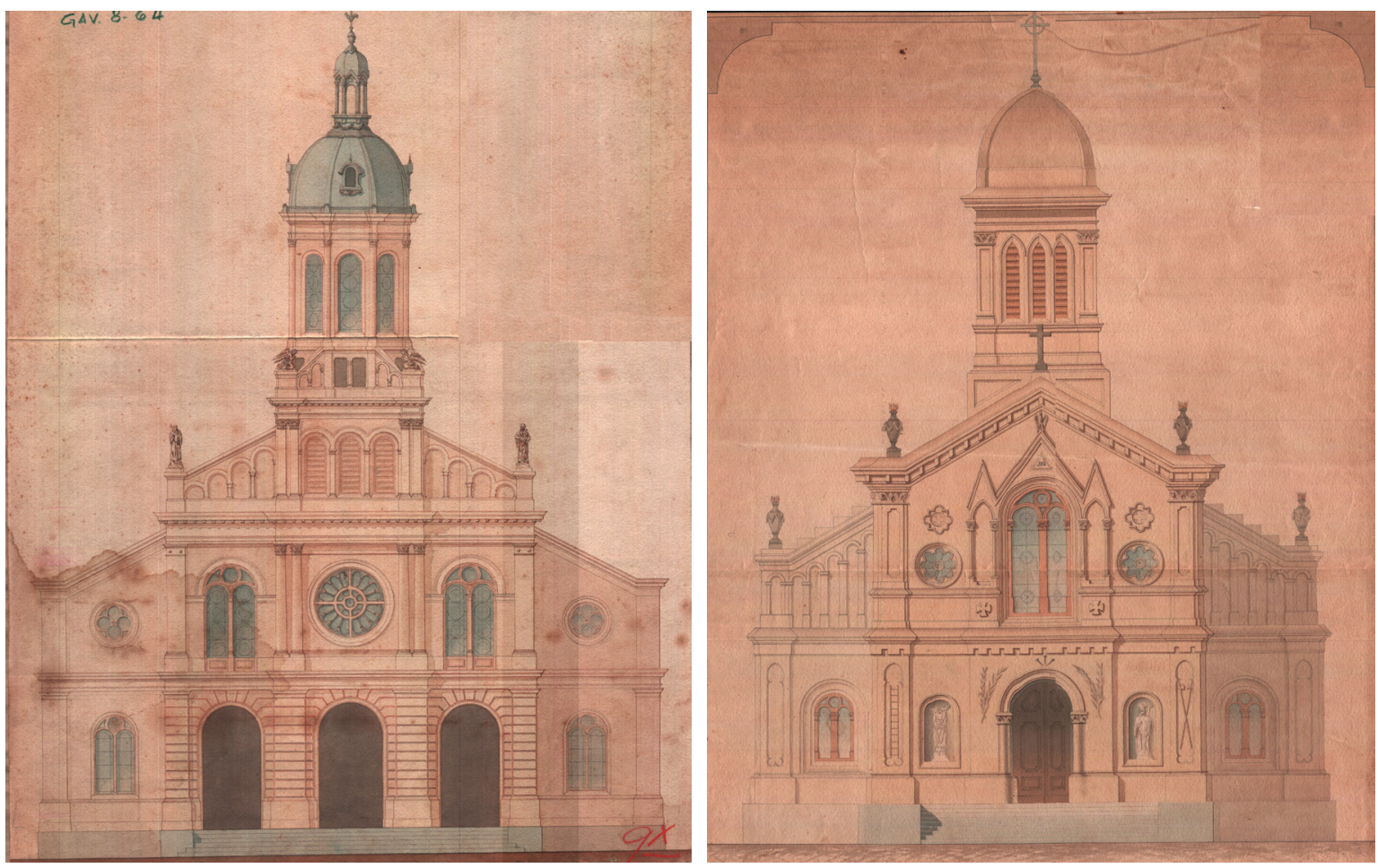

Figuras 32 e 33: Projeto de Ramos de Azevedo para a Igreja Matriz de Limeira a esquerda e para a Capela da Boa Morte a direita. Fonte: Acervo Iconográfico da Biblioteca da Faculdade de Arquitetura e Urbanismo da USP.

Após a não execução dos projetos e dada a continuação dos problemas, a Confraria da Boa Morte contrata uma comissão técnica que constatou inúmeros problemas na estrutura da capela. Os problemas de fundação foram resolvidos com enxertos de pedras e tijolos, porém, os demais problemas - como o do peso das torres e do frontispício, cuja solução seria a demolição-, não foi realizado. Assim, em 1882, a Câmara de Limeira notificou a Confraria sobre o estado da igreja, "exigindo que dê providencias para evitar qualquer desastre proveniente do estado de ruinas [...] no frontispício e a parede lateral direita do Templo da Confraria"

12 No caso da Igreja Nossa Senhora das Dores, que já havia sido construída com grandes blocos, provavelmente a nova fachada também seria construída envolvendo a antiga estrutura. 
(LIMEIRA, 1884, p.77). Novamente, em 1885, a Câmara voltou a notificar a Confraria exigindo reparos no templo que ameaçava ruir sobre os que ali passavam (ROSADA, 2010, p.139).

O problema, porém, só é resolvido em 1893, quando o fazendeiro Ernesto Mugnani encarregou-se de financiar dois terços do novo frontispício de tijolos (ROSADA, 2010, p.141). Neste mesmo ano, o frontispício foi totalmente demolido e um novo foi construído. O encamisamento da nova fachada respeitou o corpo e o desenho do antigo projeto, quanto à posição da porta central e das janelas, porém mudou-o totalmente ao prever um frontão semicircular em forma de coroa, modelo inusitado que faz da Igreja da Boa Morte, um exemplar único. O antigo, projetado por Aurélio Civatti, possuía uma linguagem neoclássica, enquanto a nova versão, formulada partir de um releitura dos elementos, o aproxima do ecletismo.

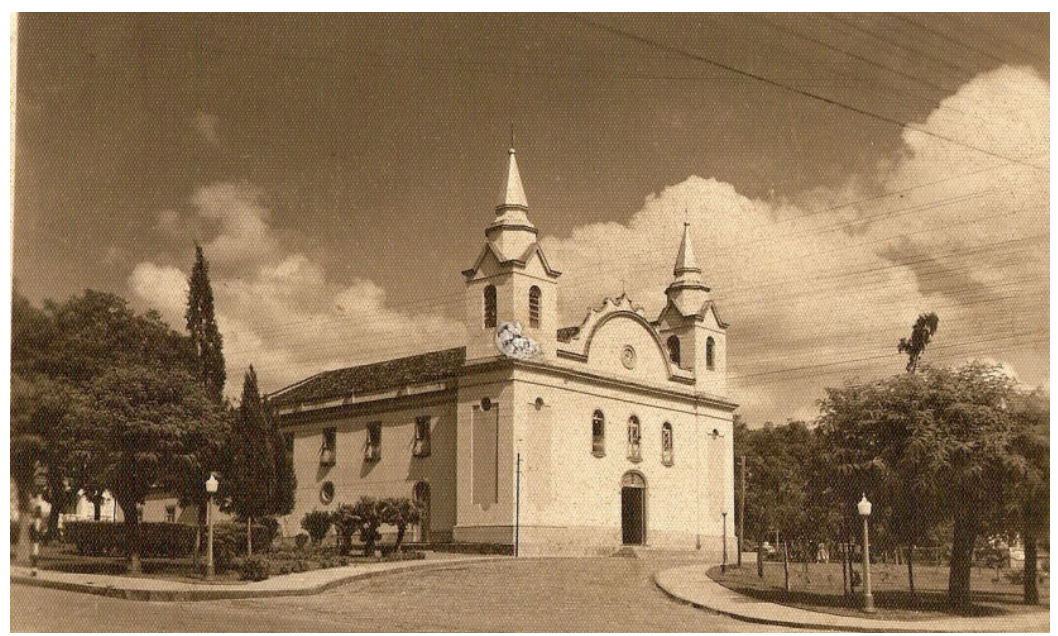

Figura 34: Igreja da Boa Morte no início do século XX, já com a reforma concluída. Fonte: Acervo da Confraria Nossa Senhora da Boa Morte e Assumpção.

Talvez, junto a essa grande reforma, a Confraria tenha realizado outras intervenções e adaptações tidas como modernização no templo, como a remoção dos antigos e largos beirais e a colocação de platibandas, alterações substanciais que não estão documentadas. Tais medidas devem ter sido adotadas devido ao código de posturas e às medidas sanitaristas, que proibiam o despejo de águas de chuva diretamente nas vidas públicas (ROSADA, 2010, p.146).

No caso da Igreja Matriz, depois de sua inauguração, a mesma passou bom tempo sem exigir grandes intervenções. Documentos paroquiais confirmam que neste período, apenas foram feitas as manutenções corriqueiras, como pintura e substituição de partes danificadas pelas intempéries climáticas. Em 1906, o pároco realiza uma campanha com o objetivo de levantar fundos para o ladrilhamento da capela do Santíssimo e reforma exterior da Matriz, "para tirarIhe a feição desagradável que então apresentava" (TOMBO II. NSD. p.47). No ano seguinte, 
é celebrado um contrato com o artista piracicabano Joaquim Miguel Dutra para a realização de pinturas de embelezamento no interior da Matriz, e também no interior da Capela da Boa Morte; infelizmente não existem relatos sobre quais seriam estas obras. A conclusão das pinturas se deu no ano de 1908, dois anos antes de ambas as igrejas receberem a instalação de energia elétrica:

Aos seis de agosto de 1.910, na matriz de Nossa Senhora das Dores da Cidade de Limeira, Estado de São Paulo, Bispado de Campinas, ficou definitivamente assentada a energia elétrica na Igreja Matriz, sendo distribuída as lâmpadas em duas sessões, a primeira comprehende toda a parte baixa da lgreja o côro da música, a segunda, a parte superior e os lustres. Compõem-se de sessenta e duas velas. As quatro arandelas da Capella Mor são de 25 velas cada uma. A lâmpada de entrada da porta principal é de 50 velas e as outras restantes são de dezesseis velas cada uma (TOMBO II. NSD. p.60).

Em sua visita pastoral de 28 de julho de 1912, o bispo diocesano faz apontamentos e adequações que deveriam ser realizadas na Igreja Matriz. Além de orientações quanto à aquisição de paramentos, posição de objetos litúrgicos e construção de novos altares, o prelado determina "que se façam grades pouco acima do tapa-vento e no arco cruzeiro, em toda a largura da Matriz, afim de haver completa separação entre homes e mulheres" (TOMBO II.NSD. p.79). Também segundo o bispo, as tribunas de agora em diante ficariam reservadas para as senhoras, e as portas laterais deveriam ser alteradas para facilitar a entrada de cada sexo para seu respectivo espaço reservado.

\section{A REFORMA DA NOVA IGREJA MATRIZ DE LIMEIRA}

É deplorável o estado material e de conservação da Matriz. Igreja grande e sólida, com muita de aproveitável em sua construção, entretanto está sujíssima, esburacada e apresenta muitos defeitos. Necessita de uma grande e dispendiosa reforma (TOMBO III. NSD.p.79).

O relato do Pe. Miguel Andery, registrado no livro tombo em 23 de agosto de 1925 logo após tomar posse da paróquia, evidencia seu descontentamento com o estado apresentado pelo templo, que suscitou um processo determinante na história da Matriz de Limeira. Logo após sua chegada, o sacerdote ordenou a manutenção no sistema de iluminação e declarou: "é meu pensamento e é uma necessidade a reforma da Matriz. Diz-se que é impossível conseguila aqui. Já falei com o Exmo. Revmo. Sr. Bispo Diocesano que animou e abençoou a ideia" (TOMBO III. NSD. p.79).

O pároco considerava que a igreja Matriz não estava à altura do município, que deveria ostentar um belo templo a altura de seu progresso material e religioso (TOMBO III. NSD. p.60). Para solucionar o problema, o pároco, em 1928, chama então o arquiteto Agostinho Balmes Odisio para estudar melhorias para o edifício, que completava 52 anos. O novo projeto propõe conservar apenas as linhas gerais das paredes, sendo que o resto desaparecia 


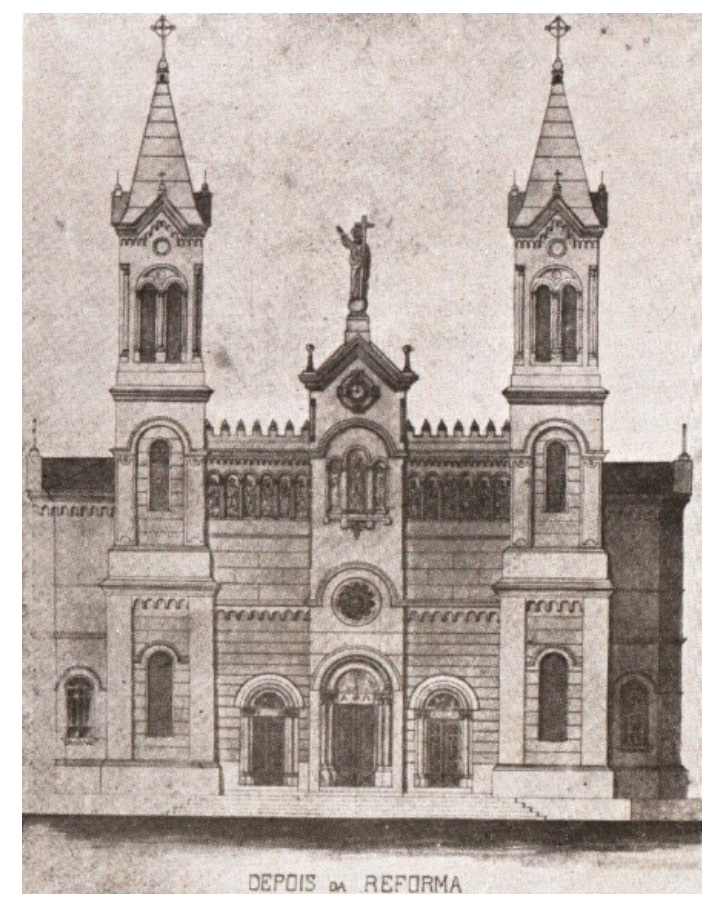

por completo. Em 01 de julho de 1929 as plantas são aprovadas, e a reforma e expansão da Igreja Matriz são viabilizadas (CARITÁ, 1998, p.173).

Figura 35: Projeto eclético de Agostino Balmes Odisio para a Matriz de Limeira de 1928, que não foi executado totalmente, apenas a parte das capelas e sacristia. Desenho de Roberto Capri. Fonte: Acervo do Museu Histórico e Pedagógico Major José Levy Sobrinho.

A pedra fundamental foi abençoada pelo bispo diocesano, que destacou a importância da reconstrução da Matriz para a cidade de Limeira, "a altura dos sentimentos religiosos de seu bom povo" (TOMBO IV. NSD. p.61v). A reforma iniciou-se com a demolição das velhas sacristias, da capela mor e da capela do Santíssimo. Devido à aderência da população local à empreitada e o grande potencial financeiro da cidade- o maior centro citrícola do país na época-, em 1930, o primeiro trecho da reforma da Igreja Matriz de Limeira encontrava-se pronto.

Figura 36: Igreja Matriz na década de 30 após a reforma, nota-se as novas capelas construídas na lateral da Igreja. Fonte: Acervo da Catedral Nossa Senhora das Dores.

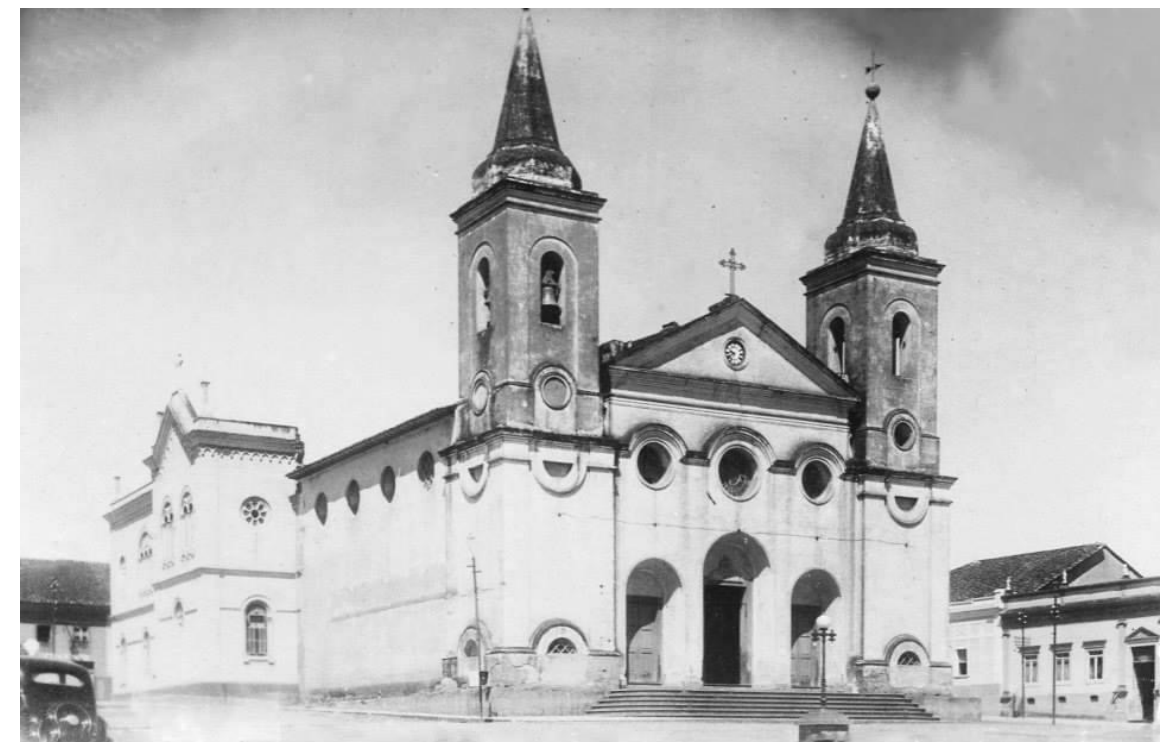


Porém, os massivos investimentos realizados na primeira fase do projeto impossibilitaram sua conclusão, que foi paralisada. Os antigos altares entalhados de Civatti foram removidos e foram construídos novos de cimento ${ }^{13}$ no lugar - sem ornamentação alguma -, gerando desconforto na população local, que lançou uma campanha para arrecadação de fundos para o embelezamento e conclusão das obras da Matriz, ao menos no trecho em que havia sido iniciado. Em 25 de junho de 1933, o então bispo diocesano Dom Barreto Leme, abençoou e consagrou o novo altar ainda em obras (TOMBO IV. NSD. p.67v).

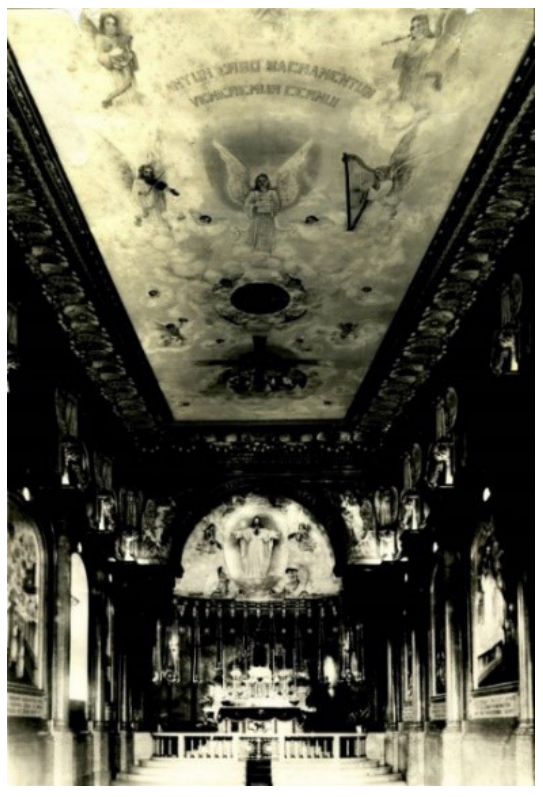

No trecho reformado, somente a nova capela do Santíssimo recebeu ornamentação. A instalação dos novos entalhes em mármore e bronze e a execução das pinturas murais, conferiu aspectos positivos ao local e agradaram a população. O recinto passou a ser chamado de Santuário do Coração de Jesus e do Santíssimo Sacramento, e em 1936, o templo parcialmente reformado foi entregue à população.

Figura 37: Nova Capela do Santíssimo da Igreja Matriz pronta. Fonte: ROSADA, 2010, p.238.

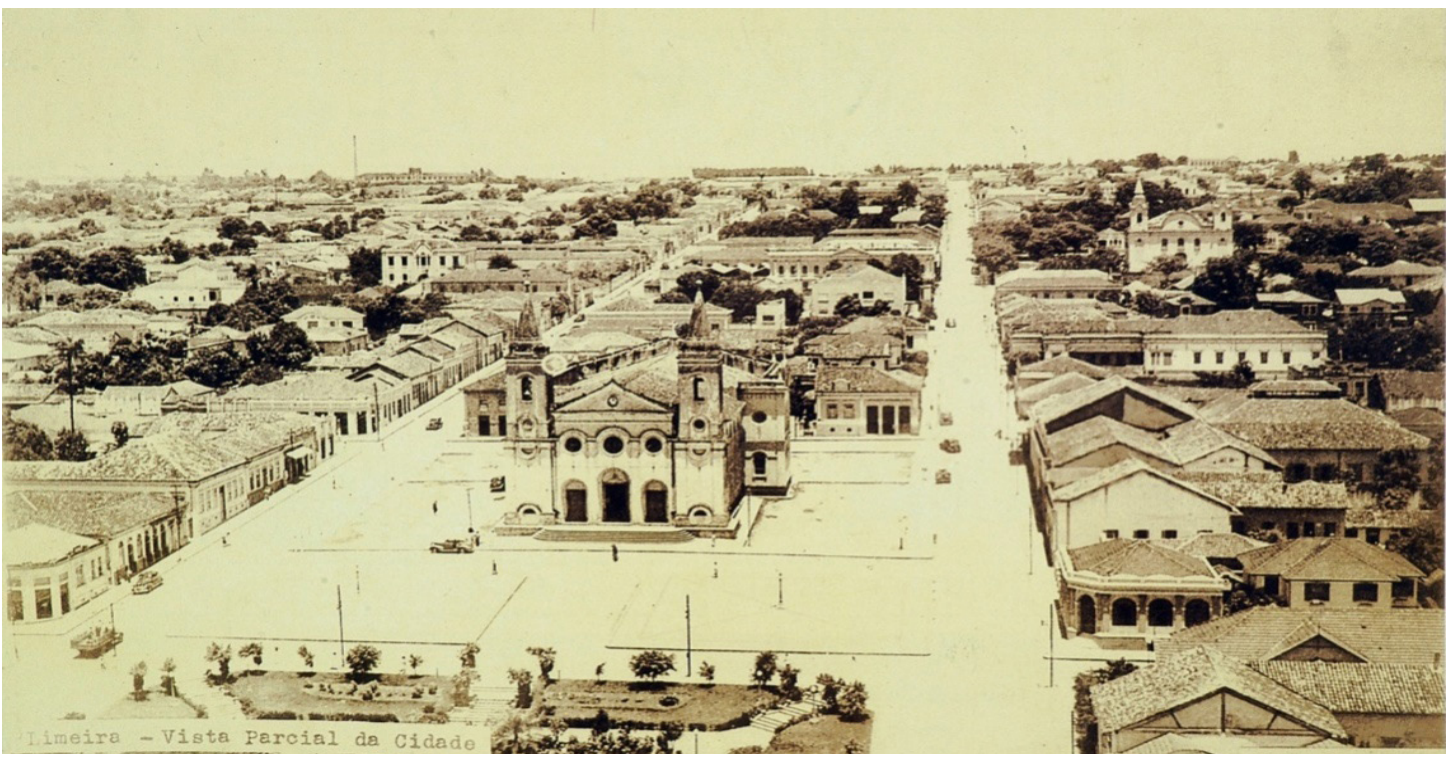

Figura 38: Vista geral da cidade de Limeira, década de 30. Fonte: Acervo da Catedral Nossa Senhora das Dores.

13 O termo cimento é utilizado pelo padre no registro das obras no livro tombo, no entanto, não se sabe exatamente como foram feitos tais altares. Possivelmente tratam-se de altares de alvenaria, que posteriormente eram revestidos com pedras e mármores, tal como é encontrado em igrejas construídas neste período. 


\section{A PARÓQUIA DE SANTA CRUZ DA CONCEIÇÃO}

A primeira capela de Santa Cruz, como já apontado no capítulo 01 (p.42), foi construída em 1842 num cruzamento da estrada que partia de Pirassununga até Rio Claro na região do ribeirão do Roque, onde havia um cruzeiro instalado desde de 1836. Com o crescimento da região e a doação do patrimônio a Nossa Senhora da Conceição em 1868, a capela foi reformada em 1872 e elevada ao grau de curato em 1876. A criação da Freguesia de Nossa Senhora da Conceição de Santa Cruz aconteceu somente em 1879, após inúmeros entraves junto ao governo diocesano. Depois de criada a freguesia, a dinâmica paroquial acompanhou as vicissitudes experimentadas pela localidade. Os altos e baixos enfrentados pela ordem pública, especialmente com a mudança do percurso da ferrovia, refletiram-se também na vida religiosa, configurando uma paróquia com ritmo e atividades próprias, vivenciando dificuldades para a consolidação da nova instituição religiosa e de todo seu aparato técnico. Problemas de ordem financeira e pastoral irão acompanhar constantemente a realidade da nova freguesia, o que será motivo de constante preocupação por parte dos párocos e do bispo diocesano. Ao longo dos anos, a paróquia passou boa parte do tempo anexada à Paróquia São Manoel de Leme, devido às dificuldades de manter um padre residente na cidade, acarretando em atendimentos esporádicos que dificultaram a expansão da Igreja naquele território.

A documentação e os livros tombos referentes à vida na paróquia testemunham essa situação em diversos períodos. Em sua primeira visita pastoral, em 15 de fevereiro de 1880, quando a igreja ainda era apenas um curato, o bispo diocesano descreve um edifício que acomodava aproximadamente 50 pessoas e que necessitava de reparos, além da construção de um local para a colocação da pia batismal, que se encontrava jogada em um canto (TOMBO I.NSC. p.02).

Nesta primeira visita pastoral, o bispo determinou melhorias a serem feitas no edifício para um melhor atendimento pastoral, além de deixar uma ajuda financeira para as necessidades eminentes do curato. As adequações que foram realizadas no edifício, possibilitaram a elevação do curato ao grau de freguesia, mas que, no entanto, não mudaram em nada a realidade local, uma vez que a dinâmica paroquial foi marcada por longos períodos sem pároco.

Assim, a igreja matriz da deficitária paróquia de Santa Cruz da Conceição foi sendo utilizada para as atividades triviais no decorrer dos anos, sem que fosse empreendida qualquer melhoria ou adequação. Como mencionado anteriormente, a maior parte da população católica era de imigrantes italianos que moravam nas fazendas de café, e participavam das celebrações que aconteciam nas capelas particulares, nas quais os padres não costumavam 
faltar, devido ao interesse que havia em manter uma boa relação com os grandes fazendeiros. Essa situação acarretava no esvaziamento da atividade paroquial urbana.

Em 1917, o recém empossado pároco Pe. Domingos Cimino aponta que: "esta matriz dava signaes de desmoronamento próximo", e por isso empreende uma campanha para uma reforma total e a "construção de uma torre que não tinha" (TOMBO I. NSC. p.15). O pedido de reforma foi aprovado pela cúria, com a instrução de que se constituísse uma comissão e que se criasse um livro para anotar os rendimentos obtidos em prol da reforma da igreja matriz.

Não há registros sobre o edifício anterior às obras realizadas neste período, e nem quais foram os serviços executados, além da construção da torre central ${ }^{14}$. As obras foram concluídas em 1918, o que sugere que não foram realizadas alterações substanciais na igreja, apenas consertos e melhorias estéticas. Em 1 de julho de 1918, o bispo diocesano concedeu ao pároco autorização para proceder a benção do edifício:

Havemos por bem conceder licença para que possa fazer a benção simples da Igreja Matriz recentemente reconstruída, e abri-la ao culto público, podendo qualquer sacerdote aprovado celebrar nela o Santo Sacrifício da Missa e demais actos religiosos (TOMBO II. NSC. p.36).

A celebração da benção aconteceu em 14 de julho de 1918, mas logo, o padre foi novamente transferido e a paróquia voltou a ser anexada à Leme.

Figura 39: Igreja Matriz de Santa Cruz da Conceição na década de 20. Fonte: CORREA, 2005, p.19.

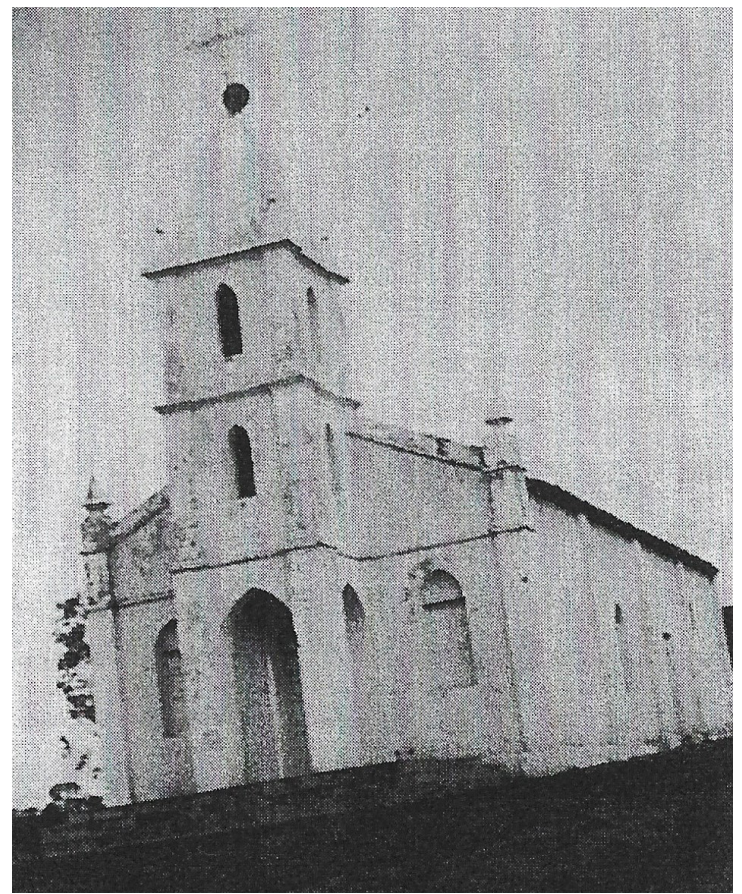

14 A torre central é um elemento corriqueiro encontrado nas tipologias religiosas mais simples do estado de São Paulo, além da planta retangular, com janelas laterais e um pequeno cone encimando a torre. Nota-se, que as pequenas igrejas guardavam semelhanças entre si, apresentando uma tipologia única e difusa por todo o território, como notaremos no caso da igreja de Iracemápolis, que será tratado a seguir. Nas cidades menores, onde as igrejas não sofreram grandes reformas ou reconstruções, é possível encontrar exemplares similares, como no caso de Conchal e Artur Nogueira, se tratando da Diocese de Limeira. 
Em 1921, um novo pároco foi nomeado e anotou algumas considerações sob a situação da paróquia, além de suas impressões do lugar, já relatadas no capítulo I (p. 48). O principal problema relatado é a falta dos pagamentos devidos ao patrimônio da paróquia, que não eram pagos à Igreja, e sim à Câmara Municipal:

Se a fábrica da Igreja tirasse rendimentos do Patrimônio da Igreja, o qual Ihe foi outorgado [...] patrimônio este que constava de 23 e meio alqueires de terra, então a fábrica poderia prover a todas as necessidades da Igreja. Mas aconteceu que, no anno de 1904, o agrimensor Jorge Tchamall veio aqui fazer nova medição deixando apenas ao Patrimônio 14 alqueires, como consta d'um mapa tirado pelo mesmo [...] pouco a pouco, o território do Patrimônio assim reduzido, veio a ser ocupado por moradores com autorização da Câmara Municipal, os quais levantaram casas, tudo isso sem licença da autoridade eclesiástica, e pagando impostos à dita Câmara Municipal. (TOMBO III. NSC. p.05v).

A ausência de um pároco em período integral administrando a paróquia e controlando os bens que dela provinham, ocasionou a perda de terras do patrimônio para posseiros que se instalaram livremente, e para a Câmara Municipal, que passou a administrar as terras e dela tirar seus proventos. No final, a Igreja acabou ficando somente com os lotes de terras onde estavam localizadas suas construções.

O problema identificado pelo pároco era fruto do descuido e abandono vivenciado pela Paróquia de Santa Cruz da Conceição, e do clero reduzido com que contava a Diocese de Campinas. Os dois problemas eram difíceis de serem resolvidos, principalmente os problemas da fábrica da paróquia, uma vez que boa parte dos moradores da área tinham documentos que provavam terem adquirido suas terras não da paróquia, e sim de outrem. Os poucos moradores que assumiam ocupar as terras do patrimônio alegavam que só aceitariam pagar aforamento com a condição de que todos fizessem o mesmo (TOMBO III. NSC. p.07).

A municipalidade, diretamente implicada nessas questões, não gostava da atuação do padre e questionava suas atitudes, ocasionando levantes contra a sua pessoa. Numa cidade onde o padre era figura esporádica e desvalorizada, falavam mais alto os que detinham o poder, e a situação continuou inalterada, em prejuízo da paróquia.

No que se refere ao templo, o relatório da visita pastoral de 1929 comenta a necessidade de ações de reparos na Matriz: "para defenda-la da ação destruidora das águas pluviais, é de necessidade examinar o telhado, cuidar das calhas, e mandar cimentar toda a roda baixa da Igreja". Deste modo, pode se dizer que a Igreja preconizava a necessidade de manutenção em seus templos, essencial para sua conservação ao longo dos anos, e além disso, reconhecia a falta que fazia um pároco para cuidar dos trabalhos necessários e das demais coisas da paróquia (TOMBO III. NSC. 31). 
Em 1932, na visita pastoral seguinte, o bispo relatou, no entanto, que nada havia sido feito em prol da melhoria da Igreja, e que a mesma necessitava de reparos urgentes no telhado para segurança do povo e um novo ladrilhamento. Ações, no entanto, que também não foram executadas.

\section{A VIDA NA PARÓQUIA DE PORTO FERREIRA}

No povoado de Porto Ferreira, com a chegada do trem em 1880 e o início da navegação fluvial no Rio Mogi-Guaçu em 1884, foi construída a Capela de São Sebastião em 1886, em terras doadas por 6 donatários para compor o patrimônio do santo, conforme descrito no capítulo 01 (p.50). Com a criação da freguesia em 1888, a Capela de São Sebastião, que se tornou Igreja Matriz, não recebeu grandes reformas e adequações em seus primeiros anos. A documentação proveniente da Paróquia São Sebastião é escassa: quase tudo se perdeu, inclusive o livro tombo. A única documentação existente são os relatórios produzidos pelos párocos, que estão armazenados na Cúria Metropolitana de Campinas.

Conforme tais documentos, a realidade vivenciada pelo padre na paróquia era difícil, principalmente no que diz respeito à administração do patrimônio, cujas terras eram quase sempre invadidas e ocupadas por forasteiros, que não pagavam nenhum valor à igreja. Em seu relatório de administração relativo ao ano de 1905, o Pe. Moysés Nora relata ameaças e ofensas que recebeu por tentar recuperar terras que estavam ocupadas irregularmente, o que fez com que seu paroquiato se tornasse um "repleto sinônimo de desgosto" (NORA, 1905, p.01).

Meia dúzia de larvados [sic] quiseram roubar o patrimônio à matriz, questão perdida já por 2 meus antecessores, e, colocada a lucta em acção, o Patrimônio ahi está reinvidicado, e seguramente restituído à Igreja [...] vencidos, quiseram peranta $\vee \underline{a}$. Ex $\underline{a}$. Menoscabar o meu nome traiçoeiramente, ardiolosamente, alvarmente (NORA, 1905, p.01).

Desta forma, os problemas pelos quais passava a Fábrica da Matriz resultavam em falta de recursos para a manutenção da paróquia e sua sobrevivência. Além do problema com as terras patrimoniais, a população da cidade havia declinado consideravelmente com a retirada das oficinas da Companhia Paulista e o encerramento da navegação fluvia ${ }^{15}$ em 1903, cujas atividades colaboravam para a manutenção da economia e para o desenvolvimento local, conforme apontado no capítulo anterior (pg. 54).

É pouco, dirão Vossas Excelências Reverendíssimas!

Sabido, porém, a escassez de recursos d'esta parochia, que não tem fonte de

15 O fim da navegação fluvial deve-se ao fato da Companhia Paulista conseguir estabelecer uma ligação ferroviária entre Rincão e Pontal, que possibilitou a chegada da empresa nas terras onde ocorria produção cafeeira em larga escala. Ver. Capítulo 01, p.53. 
receita de qualidade alguma, e com apenas 9 fazendas de café, e o movimento parochial das duas melhores d'estas anda empalmado pelo ex-vigário de Santa Cruz da Estrela ${ }^{16}$. (NORA, 1905, p.03).

Como era de prever, as dificuldades financeiras da paróquia repercutiram no edifício da matriz, que, segundo o pároco, necessitava de melhorias urgentes. A pequena capela, segundo Oliveira (2005), era simples e possuía uma pequena torre sineira de madeira que, devido ao mau estado de conservação, veio a ruir em 1902.

Apesar das ameaças de morte e de constantes atos de humilhação ${ }^{17}$, o pároco estava determinado a realizar melhorias na igreja de Porto Ferreira, cujas paredes laterais apresentavam sérios problemas estruturais, com risco de desmoronamento em alguns trechos. A reforma aconteceu somente em 1904 devido ao auxílio dado pelo Coronel Procópio Araújo de Carvalho, proprietário da Fazenda Santa Mariana e senador do Governo, que, segundo o padre, era um bom católico.

Duas paredes da matriz estavam a desabar e não havia torre. Hoje tudo está feito com a satisfação de que tudo fiz sem pedir um real a certos bandidos, e ahi ficam as obras para que em todo tempo se saiba, que para haver matriz decente em Porto Ferreira, foi necessário que eu para cá viesse (NORA, 1905, p.09).

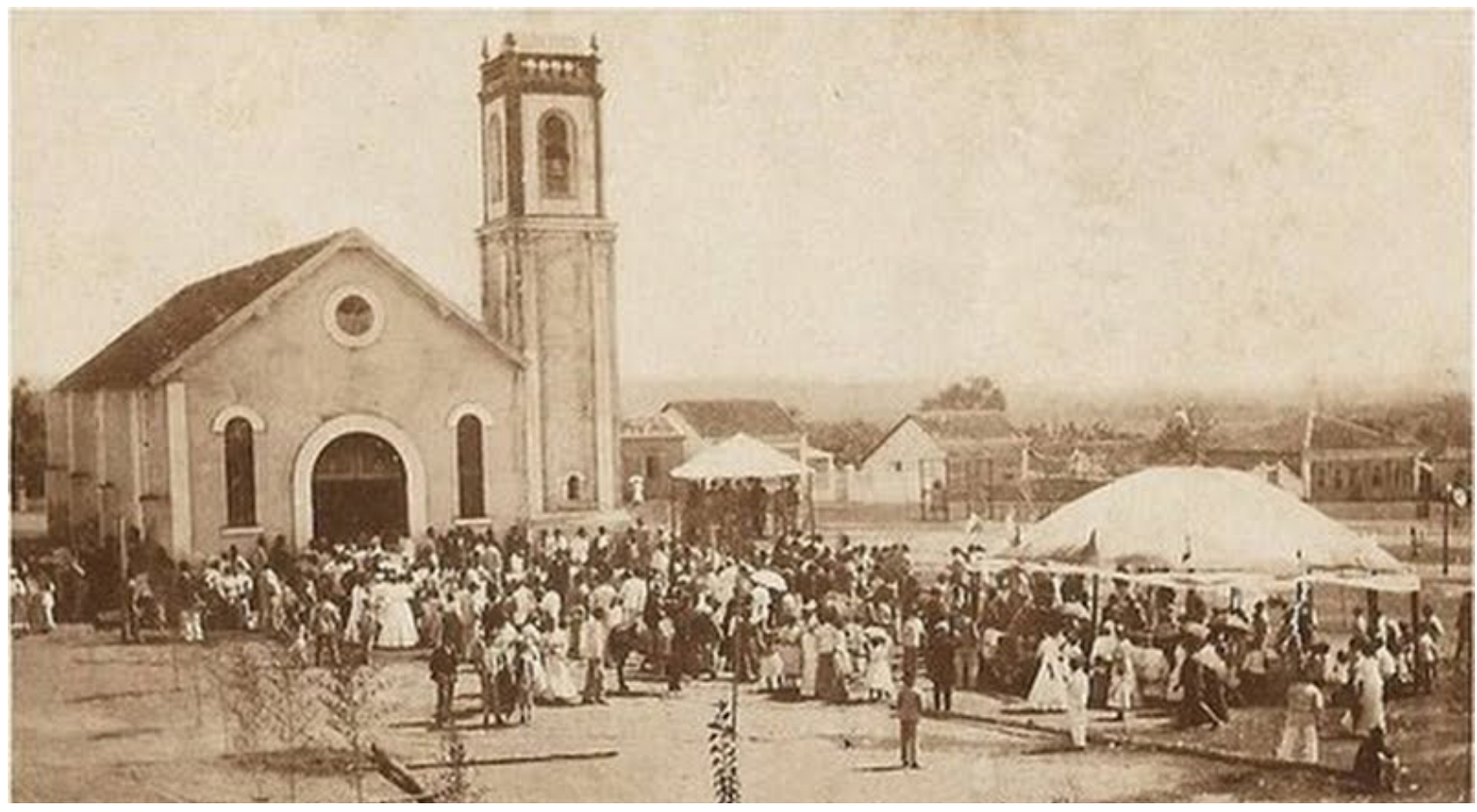

Figura 42: Igreja Matriz São Sebastião de Porto Ferreira. Fonte: OLIVEIRA, 2005, p. 50.

16 Distrito pertencente a Santa Rita do Passa Quatro.

17 O sacerdote relata que fora vítima de diversos atentados de morte no decorrer de seu paroquiato: eram feitos falsos chamados para atender a doentes que não existiam, para que, no caminho, o padre sofresse emboscadas. Além disso, a casa paroquial era emporcalhada com excremento humano junto as portas, numa tentativa de desanimar o vigário. 


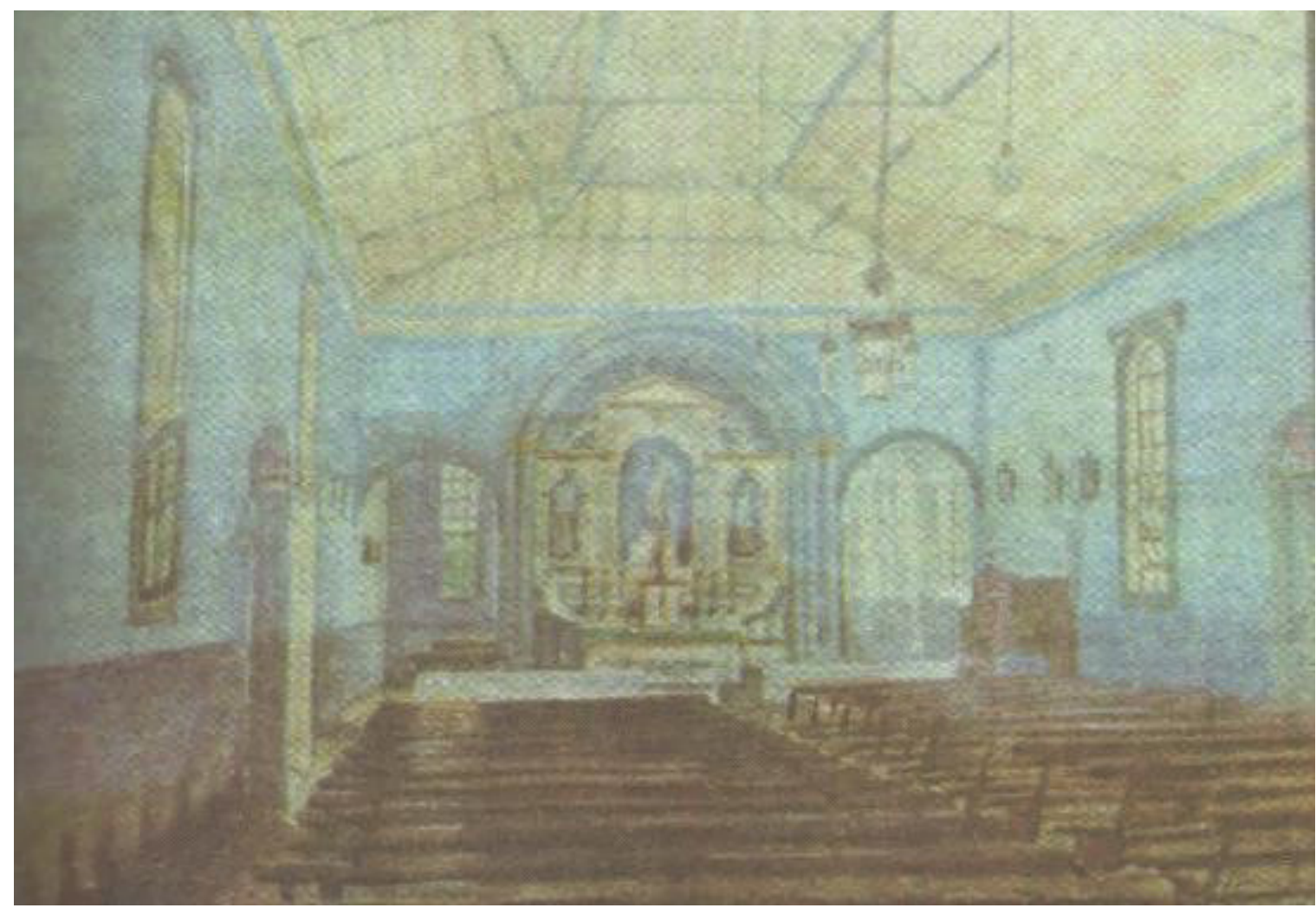

Figura 43: Interior da Igreja Matriz São Sebastião de Porto Ferreira Fonte: OLIVEIRA, 2005, p. 50.

Oliveira (2005) aponta que a igreja comportava aproximadamente 200 pessoas e recebeu novas reformas em 1920, apenas para fins de embelezamento, sem receber nenhuma alteração em seu espaço ou expansão de sua capacidade. Devido ao tamanho da cidade, e à presença de um contingente populacional muito grande nas áreas rurais, onde existia grande número de capelas particulares, o edifício da matriz atendia plenamente às necessidades do núcleo urbano.

O patrimônio, que era objeto de constante atrito e problemas para a administração da paróquia, começou a ser totalmente vendido em 1930 para os foreiros que ocupavam ainda os lotes da igreja. Dos patrimônios das paróquias objeto deste estudo, a Paróquia São Sebastião foi a que manteve por mais tempo a posse de suas terras, mesmo enfrentando graves problemas e entraves junto aos munícipes e à administração pública. No fim, as terras, que já não rendiam nenhum valor considerável para a Igreja, foram vendidas - solução encontrada pelo pároco e pelo bispo diocesano para preservar a paróquia dos problemas jurídicos pelos quais, vinha passando-. 


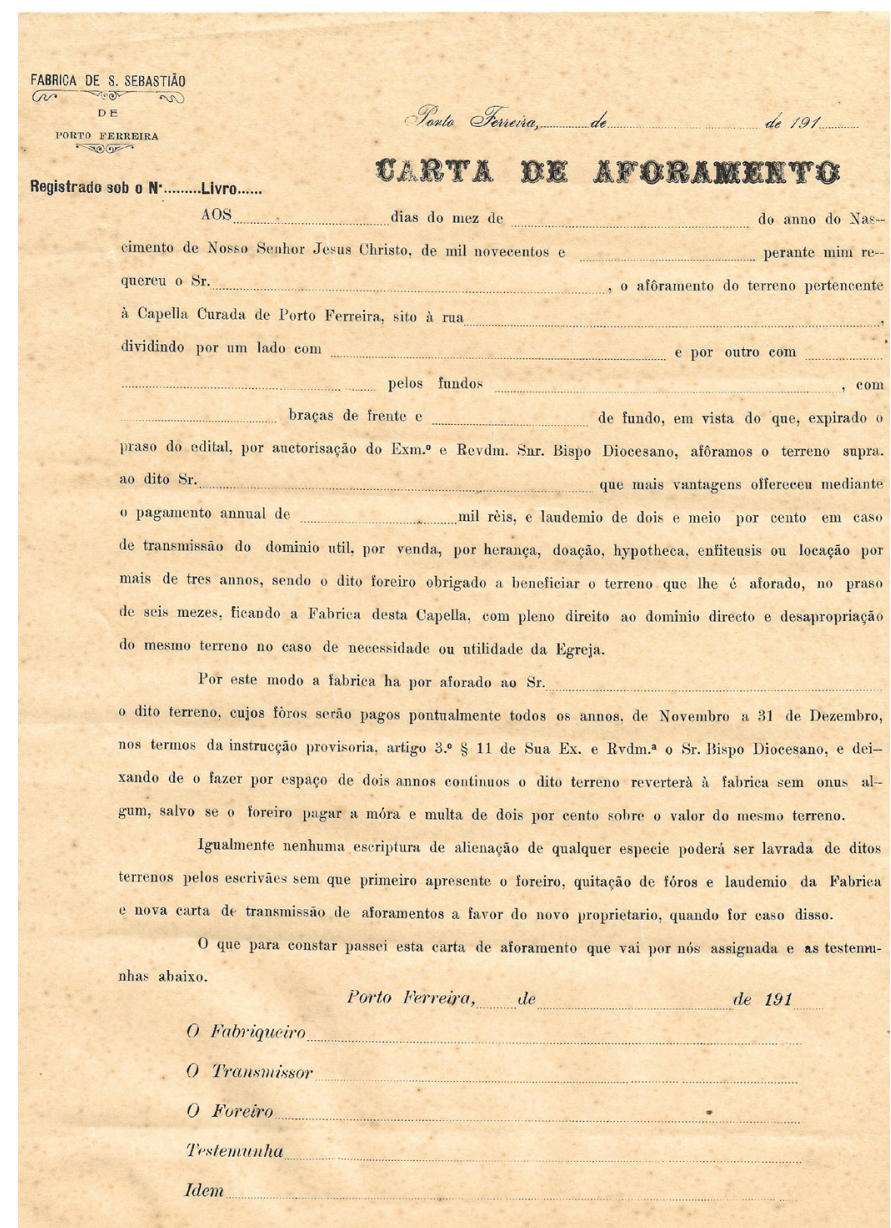

Figura 44: Modelo de carta de aforamento dos lotes utilizada pela Fábrica da Matriz de São Sebastião Fonte: Acervo do Santuário São Sebastião

\section{A CAPELA DE SANTA CRUZ DA BOA VISTA E A PARÓQUIA DE JESUS CRUCIFICADO, EM IRACEMÁPOLIS}

Assim como a cidade de Limeira, a cidade de Iracemápolis também se localiza na região da sesmaria do Morro Azul, que era ocupada por grandes engenhos e fazendas: sua gênese se dá com a doação de dois alqueires de terra em 1886 para a construção de uma capela, como vimos no capítulo 01 (p.58), A conclusão da construção da Capela de Santa Cruz em 1891 e o início de seu funcionamento possibilitou a formação de um povoado, que se tornou o bairro de Santa Cruz da Boa Vista, posteriormente denominado distrito de Iracemápolis em 1931.

A capela era atendida mensalmente pelo pároco da Paróquia Nossa Senhora das Dores de Limeira, à qual estava anexada. Os primeiros relatos referentes ao estado de conservação do edifício datam de 1925, quando o Pe. Miguel Andery, ao assumir a paróquia de Limeira, se assusta - tal como em Limeira-, com as condições em que se encontrava a capela: "minúscula, estava em ruínas, com suas paredes escoradas por tocos de madeira, pois ameaçavam ruir e em péssimo estado" (TOMBO I. JC. p.06).

A distância entre a Capela de Santa Cruz e sua Igreja Matriz, e o próprio crescimento da 
cidade de Limeira, que exigia cada vez mais a presença do pároco, preocupava o padre, tornando cada vez mais difícil a sua presença junto à comunidade de Santa Cruz da Boa Vista. Assim, tomou a providência de nomear um zelador para a capela, para que este tratasse de reformá-la e deixá-la em condições dignas para o exercício das atividades litúrgicas, e assim direcioná-la para um futuro desmembramento paroquial, uma vez que a população local também estava aumentando consideravelmente.

Dentre as melhorias realizadas no templo, foram realizadas obras de expansão ${ }^{18}$, reformas estruturais, troca do telhado e caiação das paredes, além da construção da casa paroquial, destinada ao acolhimento dos sacerdotes nos dias em que estivessem na capela (TOMBO I. JC. p.07).

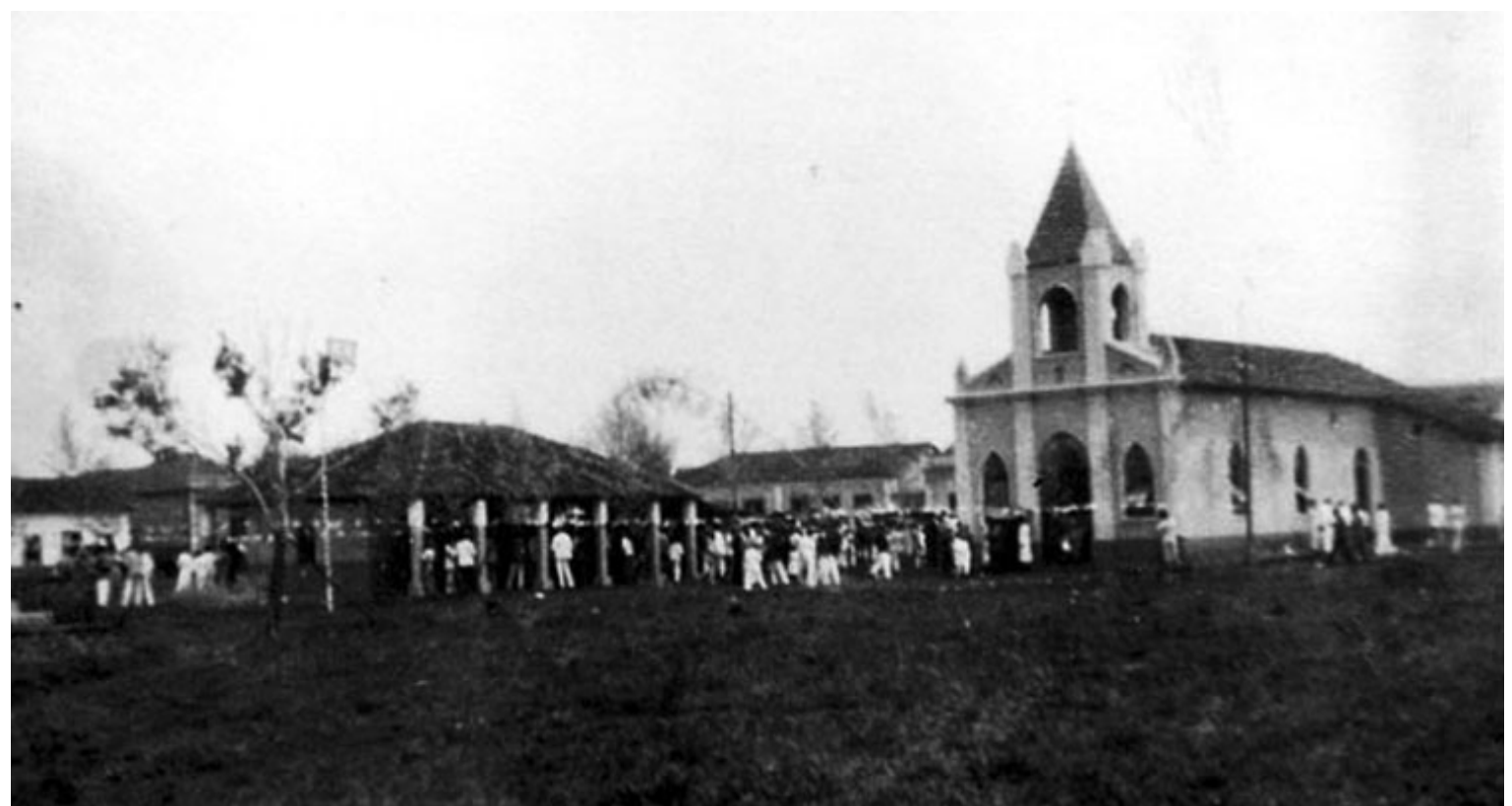

Figura 45: Festa na Praça João Pessoa (atual Praça da Matriz) em 1936. Nota-se as alterações realizadas pela reforma de 1925, como a construção de uma torre central, que conferiram a igreja características arquitetônicas clássicas encontradas nas igrejas do interior paulista, cujos exemplares ainda são encontrados em cidades menores. Fonte: Acervo da Paróquia Jesus Crucificado

Com o aumento significativo das atividades pastorais, foi criada uma Comissão Pró-Paróquia através de uma iniciativa popular, que se dirigiu ao bispo diocesano no dia 03 de fevereiro de 1936 pedindo a criação da Paróquia de Jesus Crucificado no distrito de Iracemápolis. O pedido, que foi aceito, tornou-se realidade em 27 de setembro de 1936, com a missa de instalação da Paróquia de Jesus Crucificado.

Em 16 de agosto de 1942, foi abençoado o novo altar de mármore ${ }^{19}$ colocado no interior

18 O livro tombo faz referência a expansões na primitiva capela, porém não registra quais seriam estas e como aconteceram.

19 Com a demolição da Igreja, esse altar foi desmontado e levado para a capela Santo Antônio, localizada no Bairro do Ponto. 
da igreja, obra do artista Luiz Leonardi, cuja doação havia sido feita pelos irmãos Ometto, proprietários da Usina Iracema (TOMBO I. JC. p.07). A pequena igreja matriz não será objeto de renovações e reformas, apenas manutenções ordinárias, como a substituição das telhas e a repintura das paredes em 1943, que vão Ihe garantir sua estabilidade e sua preservação, como disposto no relatório da visita pastoral, realizada pelo bispo diocesano em 05 de dezembro de 1944: "Queremos salientar a satisfação particular que experimentamos, verificando o asseio e a ordem da Igreja e os melhoramentos oportunos introduzidos" (TOMBO I. JC. 66).

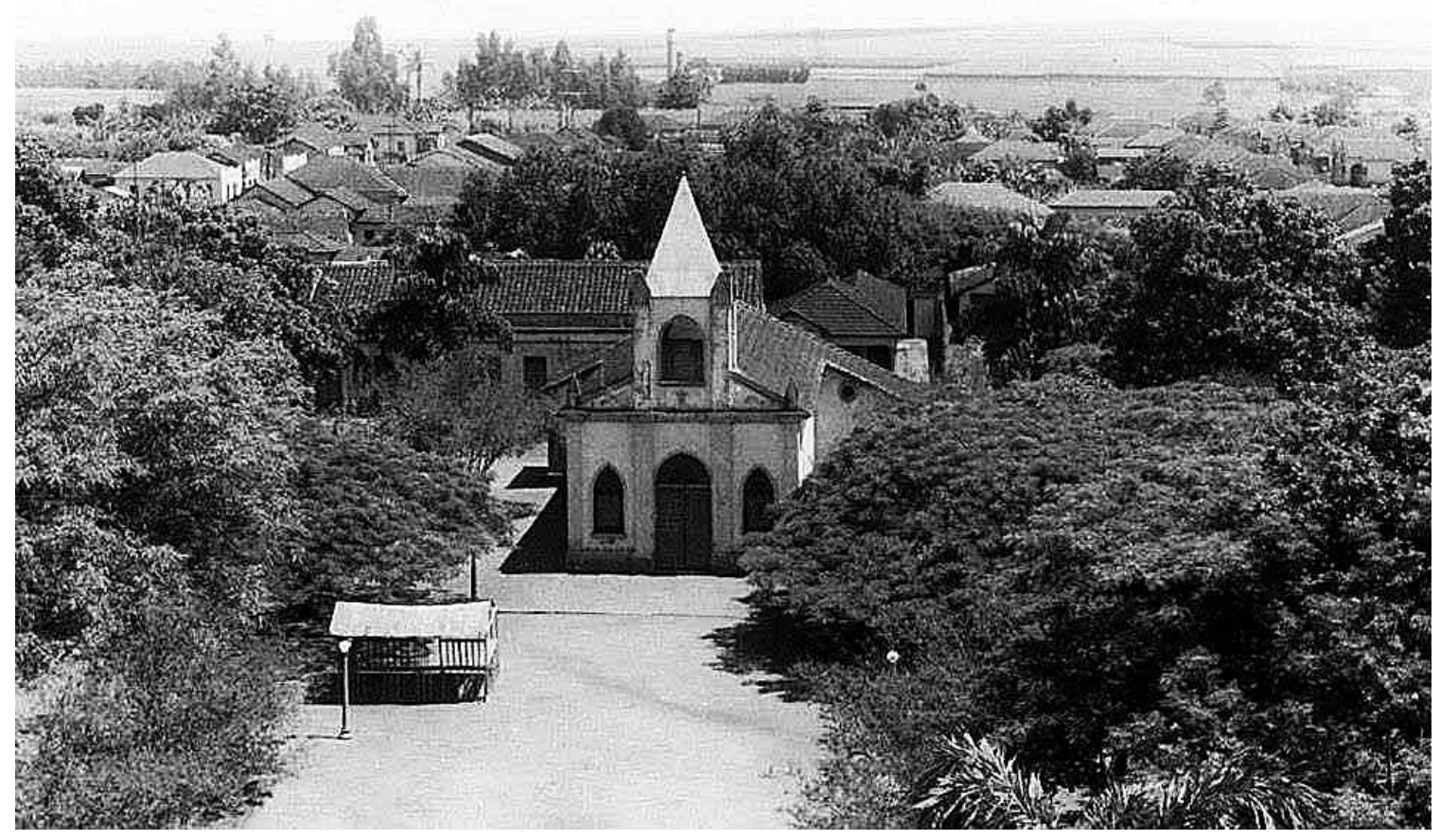

Figura 46: Igreja Matriz Jesus Crucificado de Iracemápolis em 1953 (foto possivelmente tirada da torre da igreja nova) Fonte: Acervo da Paróquia Jesus Crucificado

Durante os anos, conforme registros, foram realizadas obras de manutenção na igreja, o que indica o cuidado do pároco para com o templo. A única preocupação que paulatinamente tomará conta do presbítero e da população é o tamanho do templo, já insuficiente para acolher a população católica de Iracemápolis, cujo tamanho aumentara significativamente.

\section{A CONSTRUÇÃO DA CAPELA DE SANTA GERTRUDES E SUA ELEVAÇÃO A PARÓQUIA, NA ATUAL CIDADE DE COSMÓPOLIS}

A construção da Capela de Santa Gertrudes integra parte das ações da Companhia Usina Ester no território da atual cidade de Cosmópolis, localizada na região do Funil. As atividades da Igreja Católica na região têm início com o loteamento realizado nas terras da Fazenda 
do Funil em 1901 pelos seus proprietários, que destinaram parte de uma quadra ${ }^{20}$ para a edificação de um edifício religioso para o atendimento aos fiéis que ali estavam estabelecendo sua moradia, conforme consta no item sobre a cidade de Cosmópolis no capítulo 01 (p.69).

A primitiva capela de arquitetura eclética - cuja construção foi realizada às expensas da família Nogueira -, foi projetada pelo arquiteto Francisco de Paula Ramos de Azevedo. A capela fazia parte de um conjunto de edifícios projetados por Ramos de Azevedo para a família Nogueira, como o Palacete Irmãos Nogueira, os edifícios fabris do complexo da Usina Ester e o armazém central da Carril Agrícola da Funilense em Campinas (atual Mercado Municipal). A construção foi iniciada em 1901 e a igreja passou a ser utilizada em 1902, ainda inacabada, ficando subordinada à Paróquia São José de Mogi Mirim. Até então, o único edifício de tipologia religiosa presente na região era de origem protestante e localizava-se no Núcleo Colonial Campos Salles. Dados do Livro Tombo apontam a presença e a cooperação da população protestante na construção do templo católico ${ }^{21}$.

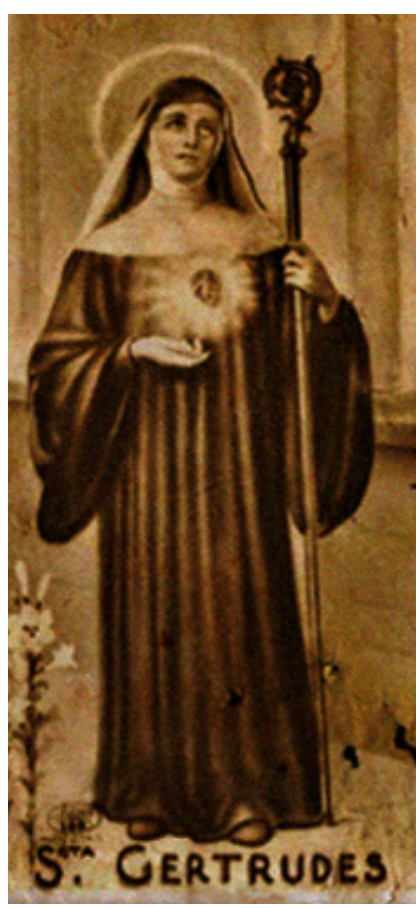

O oferecimento da Capela a Santa Gertrudes ${ }^{22}$ pode ser explicado pelo fato da matriarca da família Nogueira, a "Dona Tudinha", ter o nome de Gertrudes Eufrosina de Almeida, sendo assim uma homenagem póstuma filial e um pedido de proteção aos negócios agrícolas da família.

Figura 47: Lembrança da Padroeira de Cosmópolis de 1918. Fonte: Acervo Cosmopolense.

20 A quadra destinada foi a de número $14 \mathrm{com}$ uma área total reservada para a Igreja de $3.436 \mathrm{~m}^{2}$, dividida em duas partes, sendo: $1500 \mathrm{~m}^{2}$ para a Casa Paroquial e $1.936 \mathrm{~m}^{2}$ para a Capela, segundo a escritura de Doação lavrada em 31 de agosto de 1915. Estavam presentes Arthur Nogueira e Dr. Paulo de Almeida Nogueira, além do representante do Bispo Diocesano de Campinas (TOMBO II. SG. p.42).

21 O pároco Pe. José Nardin menciona, em 1940, no livro tombo, a existência do "Livro de Escripturação da Capela da Villa de Cosmópolis" escrito por Arnaldo Herbest no arquivo da Paróquia, cujos dados revelam o processo construtivo e a participação dos protestantes do Núcleo Campos Salles, porém o livro está desaparecido (LIVRO TOMBO II. SG. p.70v).

22 Santa Gertrudes de Helfta (1256-1302) foi uma monja beneditina que se dedicou a escrever livros sobre teologia e a revelação divina. Foi canonizada pelo Papa Clemente XII em 1677. 
Em 22 de janeiro de 1903, a Cúria de Campinas autoriza a transferência da Capela de Santa Gertrudes da Paróquia São José de Mogi Mirim para a Paróquia Santa Cruz de Campinas (atual Basílica do Carmo), após um pedido realizado pelos paroquianos ${ }^{23}$. Um ano depois, os moradores do bairro enviam um novo requerimento ao bispo diocesano pedindo um vigário para Ihes assistir nas funções espirituais ${ }^{24}$, porém, somente no ano de 1909 a capela recebe o Pe. Gregório Lanza, para direcionar ações em preparação da criação da nova paróquia. A distância da capela em relação à Igreja Matriz $(50 \mathrm{~km})$ era um problema para o atendimento e manutenção da vida religiosa dos fiéis.

No relatório da primeira visita pastoral, realizada em 02 de outubro de 1909 por Dom João Batista Correa Nery, primeiro bispo de Campinas, destaca-se se necessidade de construção de uma casa paroquial ${ }^{25}$ e melhorias no templo para adequá-lo ao culto litúrgico, como a construção de dois anexos na parte posterior do templo, para servir de sacristia e capela, a instalação da pia batismal e um tapa-vento na porta principal (TOMBO I. SG. p.01). Entretanto, somente em 1913 será pedido à Prefeitura de Campinas a autorização para a construção dos anexos mencionados. Estes transformavam o edifício de corpo único longitudinal em uma planta em forma de $T$, inserindo dois volumes nas laterais do edifício, um de cada lado. $O$ projeto foi aprovado junto à prefeitura em 24 de setembro de 1913 e tinha como construtor responsável Carmelo Zarmmolorv ${ }^{26}$. É neste ano também que a luz elétrica chegará até a Vila de Cosmópolis ${ }^{27}$ e será instalada na capela (TOMBO I. SG. p.52v).

23 Conforme registro encontrado no Livro Tombo I da Paróquia Santa Cruz de Campinas, pág. 23v, localizado na Cúria Metropolitana de Campinas.

$24 \quad$ No documento datado de 14 de janeiro de 1904, os fiéis argumentam o rápido crescimento da Vila de Cosmópolis e a longa distância com as paroquias mais próximas (Campinas e Limeira), caso desejassem participar das atividades religiosas nos dias em que o vigário da Paróquia Santa Cruz não estava na capela.

25 O projeto de construção da casa Paroquial será apresentado na Repartição de Obras Municipais da Prefeitura de Campinas apenas em 13 de julho de 1915, cuja autoria é assinada por Frederico Correa da Silva e Domingos Ventriglio.Atualmente, encontra-se no Arquivo Municipal de Campinas (BR SPAMC 0102-1915/445) 26 Dado extraído do projeto de ampliação apresentado à Repartição de Obras Municipais da Prefeitura de Campinas, datado de: 23 de setembro de 1913, sendo encontrado atualmente no Arquivo Municipal de Campinas (BR SPAMC 0102-1913/705))

27 É importante salientar que neste caso, vila refere-se a bairro e não a instituição política territorial, como acontecia anteriormente. 
Figura 48: Projeto de ampliação da Capela de Santa Gertrudes apresentado em 23 de setembro de 1913 à Repartição de Obras Municipais da Prefeitura de Campinas. Fonte: Arquivo Municipal de Campinas

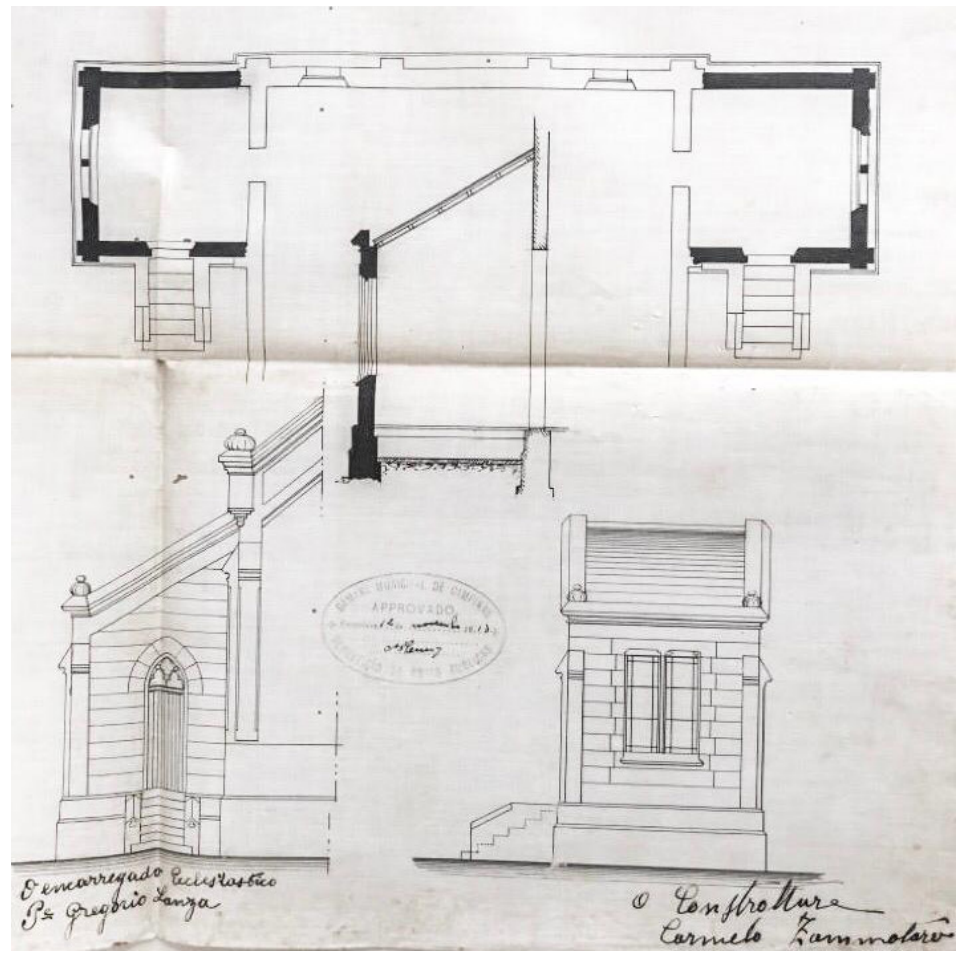

A conclusão da construção se dá no ano de 1915, com a doação oficial do terreno pela Sociedade Anônima Usina Ester em 31 de agosto ${ }^{28}$, com a instalação da Paróquia de Santa Gertrudes e com a inauguração oficial da agora Igreja Matriz, em 17 de setembro de 1915. O evento contou com a presença de figuras políticas ligadas ao Governo do Estado, da cidade de Campinas e da família Nogueira, benfeitora do empreendimento.

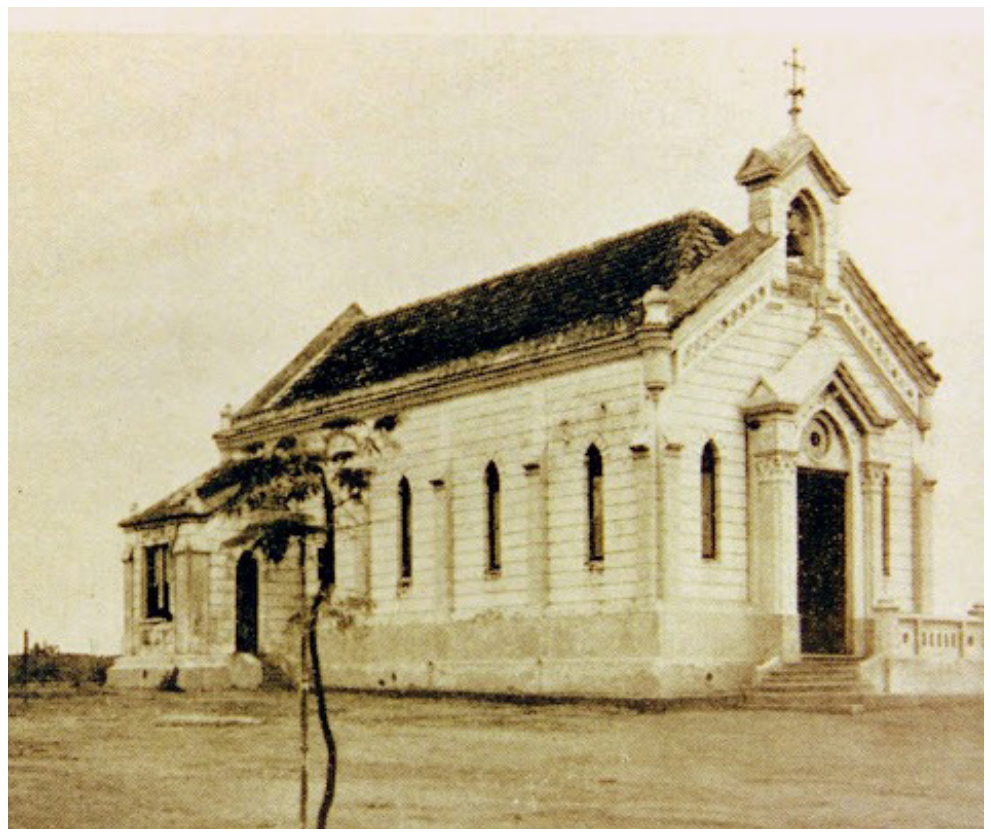

Figura 49: Capela Santa Gertrudes em 1915. Fonte: Acervo da Paróquia Santa Gertrudes.

28 Segundo documento lavrado no Cartório do Distrito de Paz de Cosmópolis pelo Sr. Antônio Moraes. (LIVRO TOMBOII. Paróquia Santa Gertrudes, p.2v) 
Figura 50: Foto da Inauguração da Igreja Matriz Santa Gertrudes em 1915, com destaque para a presença dos membros da Família Nogueira e autoridades políticas. Fonte: FERREIRA, 2011, p. 279.

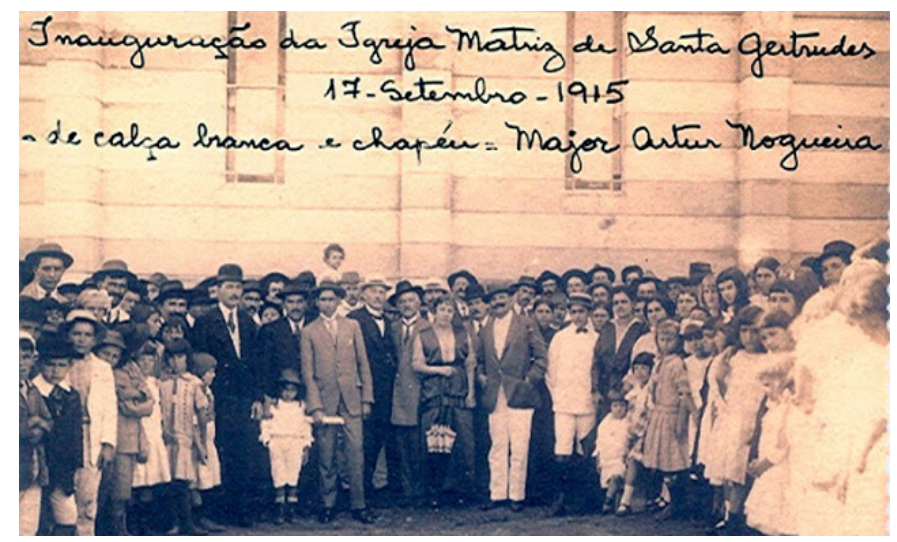

\section{O sr. d. Joâto Nery, bispo dio-} cesano, mandou lavrar o decreto creando a nova parochia de Cosmopolis, desmembrada d. de Santa Cruz.

Figura 51: Nota no Jornal "Correio Paulistano" de 22 de setembro de 1915 referente a criação da Paróquia.Fonte: Hemeroteca Digital.

O edifício, apesar de ser bem projetado e bem construído, tinha as proporções de uma pequena capela, insuficientes para as necessidades de uma matriz paroquial, mesmo com as ampliações realizadas a pedido do bispo diocesano. No que se refere a sua aparência, a mistura de elementos oriundos de diversos estilos de arquitetura caracterizavam a arquitetura eclética realizada por Ramos de Azevedo ${ }^{29}$. Destaca-se também a presença de outro importante profissional que trabalhou no empreendimento, responsável pelo desenho de todos os ornamentos presentes na Capela, Felisberto Ranzini, funcionário no escritório de Ramos de Azevedo e professor do Liceu de Artes e Ofícios.

Figura 52: Igreja Matriz na década de 30. Sua arquitetura eclética era composta de frisos horizontais, molduras nos vãos, beirais ornamentados. Além de um pequeno campanário na parte mais alta da fachada principal, a porta central possuía uma espécie de frontão com duas colunas de ordem compósita. As laterais do edifício, os pilares apresentam uma estrutura semelhante à nascente de um arco botante, e as janelas em ogiva. Fonte: FERREIRA, 2011, p. 279.

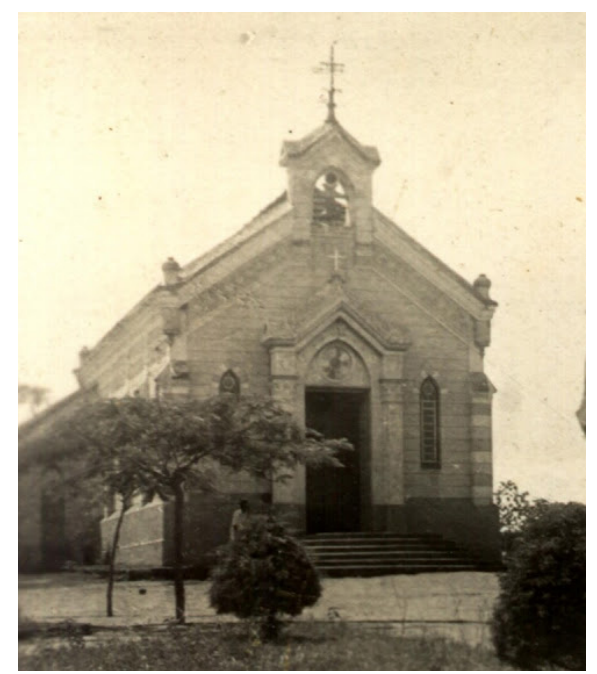

29 É valido destacar o projeto realizado por Ramos de Azevedo para a fachada da Igreja São Benedito em Campinas em 1885, cuja estrutura e ornamentação são semelhantes a capela de Cosmópolis, porém em escala menor. 
Quanto à decoração, a capela era muito simples, possuía um piso de mármore e altares em talha de cedro para a colocação de imagens. Segundo o inventário de bens que consta no livro tombo do ano de 1918, a capela contava com 23 bancos para fieis, comportando aproximadamente 125 pessoas (TOMBO I. SG. p.20v).
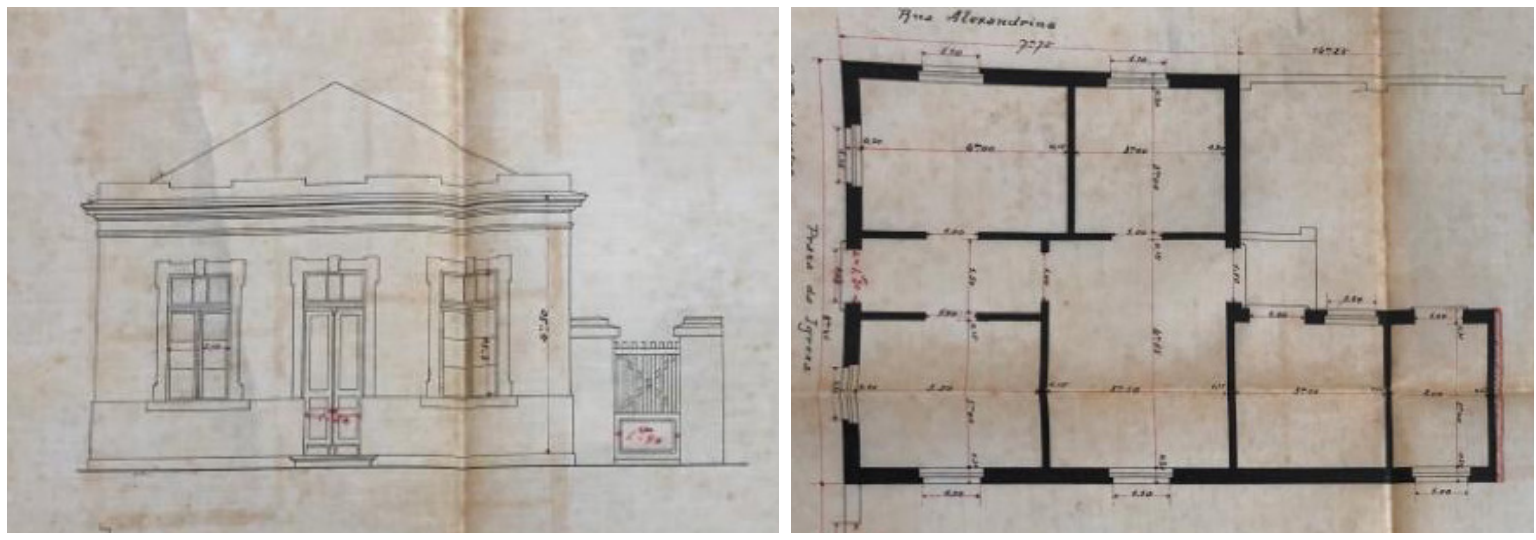

Figura 53: Projeto de construção da casa paroquial apresentado à Repartição de Obras Municipais da Prefeitura de Campinas em 13 de julho de 1915. Fonte: Arquivo Municipal de Campinas.

\section{AS VICISSITUDES DA PARÓQUIA SANTA GERTRUDES}

O crescimento da vila de Cosmópolis e da Paróquia Santa Gertrudes se deu de maneira lenta e progressiva, sempre ligado aos interesses e ações da Usina Ester. Foram longos anos sem intervenções pontuais no edifício da igreja, apenas relatos de obras de manutenção na casa paroquial, e a colocação de novas imagens sacras na igreja. São inúmeras as reclamações quanto às dificuldades financeiras enfrentadas pela paróquia devido à pobreza da população residente no entorno, além da dependência constante dos Nogueira para a realização de qualquer benfeitoria no templo.

A primeira grande intervenção na Igreja Matriz ocorrerá a pedido do padre Victor Randuá à Cúria Diocesana somente em 1933, 18 anos após sua inauguração. O pedido relata fragilidades estruturais no edifício e a necessidade de renovação de sua aparência:

A matris de Cosmópolis, que há muito tempo não recebeu reparações de importância, está precisando de um concerto geral no telhado, com a renovação das calhas de metal, afim de evitar-se que em tempos de chuvas a água escorra pelas paredes internas, como há muito tempo tem acontecido, e assim também está precisando de uma limpeza e pintura das paredes externas e internas (TOMBO II. SG. p.32).

No final do pedido, o pároco relata que o orçamento para as obras estava estimado em cento e quinhentos mil réis, sendo que parte deste montante já tinha sido arrecadado com a festa de Santo Antônio e com doações da Usina Ester, sendo ainda necessário arrecadar junto à população a parte faltante (TOMBO II. SG. p.33v). É interessante notar que mesmo 
sendo considerada como uma primeira grande intervenção no edifício, não se trata de transformações substanciais no templo, mas sim obras de manutenção ordinária, que foram executadas ainda no ano de 1933. O presbítero também registra algumas impressões que teve quanto à vida da população e à dinâmica da paróquia de Cosmópolis. O primeiro ponto levantado pelo eclesiástico é a localização da capela, "distante, num lugar ermo e não povoado", o que indica que a grande massa de habitantes estava no Núcleo Campos Salles, considerado por ele como um lugar de "pessoas frias e sem interesse pela fé católica". O segundo diz respeito à fraca participação da população nas atividades religiosas e à falta de comprometimento com as atividades da Igreja, além das dificuldades que tinha de enfrentar para atender a Capela de Nossa Senhora das Dores, localizada no povoado da atual cidade de Artur Nogueira. O controle realizado pela Usina Ester parece também incomodar os presbíteros que passaram por Cosmópolis, devido à necessidade constante de atenção e préstimos de serviços, chegando a parecer que eram funcionários da Companhia. Porém, sempre é muito clara a necessidade de se manter uma boa relação com a Família Nogueira (TOMBO II. SG. p.38).

Em 1940, o tamanho e a simplicidade da Igreja começam a incomodar o pároco e os munícipes, por não acomodar todos os fiéis católicos de Cosmópolis nas celebrações. Será feito um requerimento à Cúria Diocesana pedindo a aprovação de um projeto de ampliação da igreja ${ }^{30}$, porém, nenhuma obra foi executada neste ano. Novamente, em 1943, será lançada uma campanha pela reforma total da Igreja. A situação financeira da Paróquia, que nunca foi boa, estava ainda mais complicada devido a uma taxa de construção Pró-Seminário imposta pela Cúria de Campinas, o que fez com que o vigário fosse buscar novamente ajuda junto à Usina Ester. Após entraves com os proprietários ${ }^{31}$, os mesmos decidem novamente financiar a reforma, doando materiais e operários para a realização da mesma (TOMBO II. SG. p.103). O relatório gerado pela visita pastoral realizada em 1943 descreve uma igreja muito organizada e adequada ao culto litúrgico, porém muito pequena para acomodação

$30 \quad$ No documento de 12 de agosto de 1940 encontrado na caixa de requerimentos da Paróquia Santa Gertrudes a Cúria Metropolitana, o pároco pede a aprovação de um projeto de ampliação da Igreja, cuja planta estava anexada, porém não existe nenhum desenho junto ao documento atualmente e nenhum registro de obra na Igreja nos livros competentes, além de que, a única ampliação realizada no edifício da Igreja foi a de 1913.

31 A relação com a Usina Ester, necessária para o sustento da Paróquia, não agradava aos párocos que passaram por Cosmópolis, especialmente ao Padre José Nardin, que questiona o tratamento de operário dado aos vigários pela liderança da Usina. Relata dificuldades em conversar com o Sr. Paulo Nogueira para angariar fundos para a reforma da Matriz, especialmente após não ser recebido em São Paulo no escritório da companhia. Após tal desfeita, o padre abdica do salário mensal oferecido pela Companhia e levanta junto aos operários uma luta pelos seus direitos trabalhistas, como o direito de folgar aos domingos e dias de preceitos e melhorias nas condições de trabalho, justificando ser a usina exploradora dos seus colonos e má recompensadora. Após esses entraves, o próprio Paulo Nogueira se dirige à Matriz de Cosmópolis e resolve a situação com o pároco. (TOMBO III. SG. p.98 a 104) 
dos fiéis e o tamanho da cidade (TOMBO II. SG. p.105).

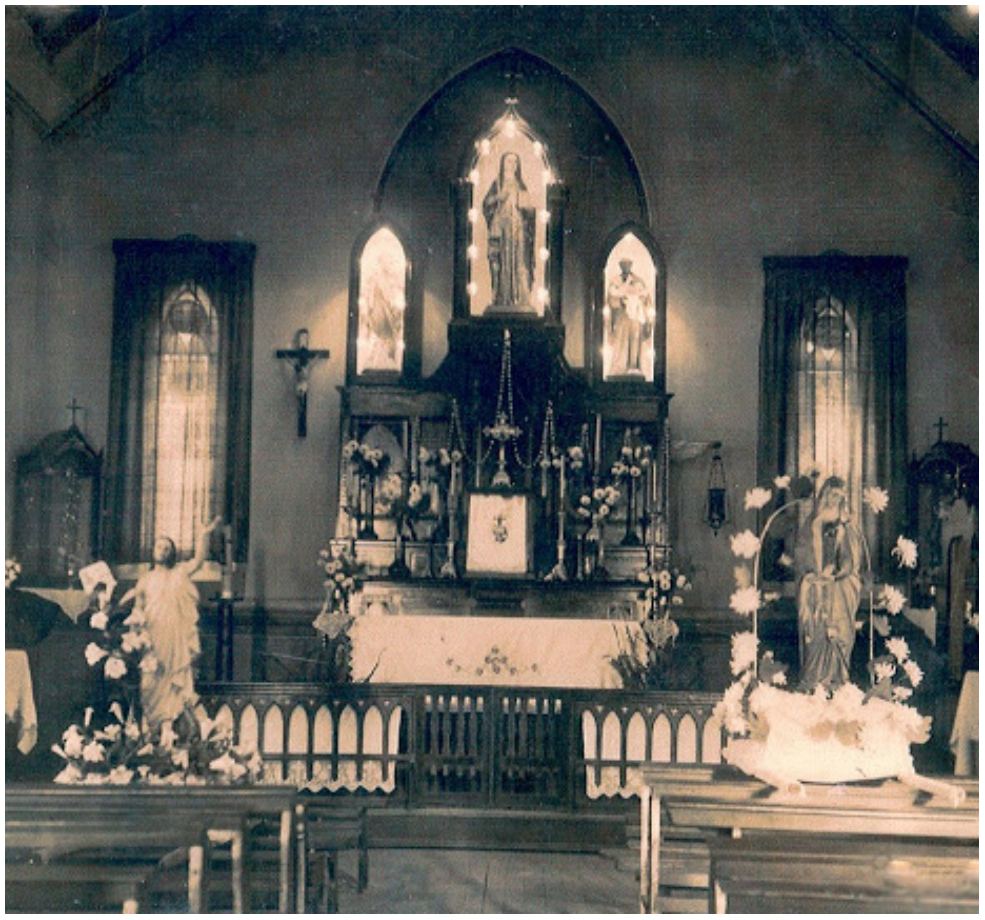

Figura 54: Interior da Igreja Matriz Santa Gertrudes em 1940. Fonte: Acervo da Paróquia Santa Gertrudes

Após dois anos, a Igreja Matriz passa novamente por alterações para melhor conforto e embelezamento, agora com a substituição das antigas e deterioradas janelas por vitrais, que possibilitavam uma abertura maior das envasaduras para ventilação e conforto climático dos fiéis. Para esse serviço foram contratados profissionais de serralheria e vidraçaria de Campinas. Houve também a mudança de posição dos altares laterais, visando otimizar o uso do espaço interno: as peças foram colocadas próximas do presbitério, sendo centralizadas na primeira janela, gerando assim mais espaço para acomodação dos fieis no interior do templo (TOMBO II. SG. p.120). Contudo, tais mudanças não solucionaram definitivamente $f$

o problema da incapacidade do templo de acomodar todos os fiéis em seu interior.

Figura 55: Missal Campal realizada em 01 de janeiro de 1945 em homenagem a emancipação do município de Cosmópolis. Fonte: Acervo da Paróquia Santa Gertrudes

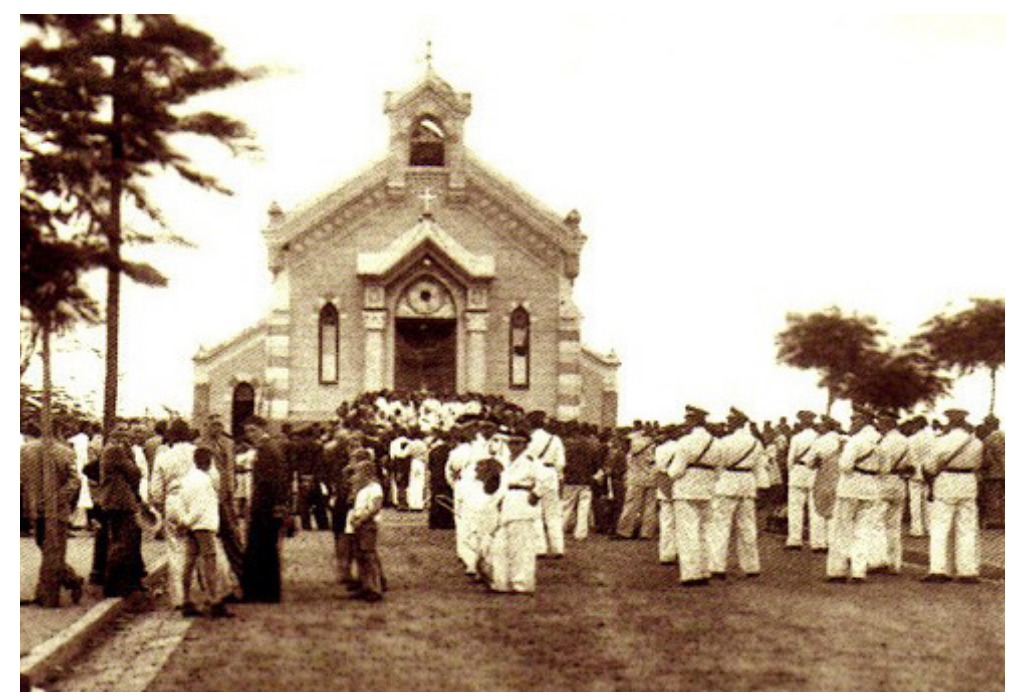



CAPITTUOOO 


\section{CAPITTLLO 03}

\section{UM DESEJO DE MODERNDADE \\ REFORMAS E RECONSTRUÇÕES \\ O NEOCOLONIAL CHEGA A FUTURA DIOCESE DE LIMEIRA}

O século XX é marcado por grandes transformações sociais no Brasil e no mundo, que resultaram em mudanças paradigmáticas na arquitetura e no urbanismo. Na primeira metade do século XX, ocorreram mudanças radicais e estruturais nas cidades e em seus edifícios, devido ao rápido crescimento urbano, ao advento de novas tecnologias e ao emprego de novos conceitos e estilos arquitetônicos. Do ponto de vista do presente trabalho, destacase, neste período, o processo de demolição e reconstrução de igrejas em várias cidades do interior paulista, devido à remodelação urbana e à construção de novos templos em estilos mais condizentes com os novos padrões tidos como símbolo de modernidade e desenvolvimento.

$\mathrm{Na}$ efervescência experimentada pelo campo da arquitetura, com o alargamento das possibilidades construtivas oferecidas pela industrialização, bem como de referências projetuais, novas questões passaram a compor o debate e a concepção de projetos arquitetônicos. Neste período, eram predominantes apropriações estilísticas provenientes da Europa no território brasileiro principalmente o neoclássico e o ecletismo. Dentre as variadas formas que houve de disseminação desses estilos pelo Brasil, destaca-se a chegada da Missão Francesa e a formação erudita introduzida pela Academia Imperial de Belas Artes fundada em 1816 (ATIQUE, 2011, p.174). O ecletismo, praticado por toda Europa, especialmente no último quartel do século XIX, foi muito bem aceito pela elite e empregado na construção de muitos edifícios públicos.

Os projetos de renovação urbana reconfiguraram as cidades e seus edifícios, que passaram a ser projetados e construídos em uma infinidade de novos arranjos arquitetônicos, possibilitados com o avanço das tecnologias construtivas e o surgimento de novas vertentes e expressões artísticas.

No Brasil, com a renovação vivenciada na época, que ia além do campo técnico e cientifico, e adentrava questões de cunho social e intelectual, surgiram questionamentos quanto à 
identidade e à valorização da história brasileira, aspectos que passaram a constituir motivo de debate a partir de então.

No ambiente arquitetônico, este questionamento recaiu diretamente sobre a replicação de modelos importados da Europa e produzidos em larga escala nas cidades brasileiras, como Rio de Janeiro e São Paulo. Tal problemática suscitou pesquisadores e arquitetos a se voltarem para a produção arquitetônica brasileira de outrora, especialmente a do período colonial, buscando encontrar nela, valores, símbolos, soluções estéticas e arranjos que apresentassem potencialidades para serem replicadas e utilizadas nas construções brasileiras da época, gerando assim uma arquitetura de valor identitário para o pais, que foi posteriormente denominada de Neocolonial.

Deste modo, trataremos neste capítulo da repercussão dos processos de renovação urbana e social vivenciados pelas cidades da região na materialidade de alguns de seus edifícios religiosos, resultando em reformas ou reconstruções na metade do século XX, nas quais foi adotado o estilo Neocolonial. Apontaremos os agentes envolvidos em tais obras e na concepção dos projetos, buscando identificar as possíveis razões da adoção de um estilo originalmente ancorado na ideia de uma identidade nacional, para a reconfiguração de um edifício de forte presença simbólica nas cidades, como vimos nos capítulos anteriores.

\section{1 - O MOVIMENTO NEOCOLONIAL}

O Neocolonial - estilo em questão nesse estudo - tem origem na segunda década do século XX com Ricardo Severo, engenheiro português radicado no Brasil, que, atento às transformações e avanços da época, conduziu trabalhos e discursos permeados por seu interesse na arqueologia portuguesa, que contribuíram de modo efetivo na retomada e valorização do passado colonial brasileiro (PINHEIRO, 2011, p.30).

A primeira manifestação em favor do que viria a se tornar o movimento Neocolonial aconteceu por meio de uma palestra proferida por Severo em 20 de julho de 1914, na Sociedade de Cultura Artística de São Paulo, intitulada "A Arte Tradicional no Brasil", um ano após o início da construção da nova Catedral da Sé. O conteúdo da palestra e os apontamentos referentes à arquitetura colonial brasileira feitos por Severo foram apoiado na escassa documentação existente até então, referente à arquitetura colonial brasileira, especialmente a produzida por Debret no Rio de Janeiro. Nesta primeira conferência, Severo afirma a necessidade de buscar referências em nossa própria tradição, para se criar uma arquitetura nacional, como descreve a seguir:

Não procurem ver, meus senhores, nesta veneração tradicionalista, diluída em nostálgica poesia do passado, uma manifestação de "saudosismo" romântico e retrogrado. Com efeito, para criar uma arte que seja nossa e de nosso tempo, cumprirá, qualquer que a seja orientação, que não se pesquisem motivos, origens, 
fontes de inspiração, para muito longe de nós próprios, do meio em que decorreu o nosso passado e no qual terá que prosseguir nosso futuro. Ficará bem explicito que não intima ao artista de hoje a postura inerte da esfinge, voltada em adoração estática para o passado, mas sim a atitude viva do caminhante que, olhando para o futuro, tem de seguir um caminho demarcado pela experiência e pelo estudo do passado, e cuja única diretriz é o progresso e a glória das artes nacionais (SEVERO apud. PINHEIRO, 2011, p.39). [grifo nosso]

Severo aponta ainda que a arquitetura se concretiza numa arte de caráter social, que vai além de "obras primas dos artistas geniais e manifestando-se nos artefatos humildes do povo" (PINHEIRO, 2017), evidenciando desta forma, a adequação da arquitetura colonial brasileira ao meio em que fora construída, denominada por ele como Arte Tradicional. Tal discurso, além de valorizar a produção colonial no Brasil, ressaltava a influência da arquitetura portuguesa nas edificações brasileiras. Em suas análises, conforme aponta Pinheiro (2011), Severo privilegiava a natureza dos materiais e a técnica construtiva empregada, adotando uma abordagem totalmente atípica das usuais da época para o estudo da arquitetura.

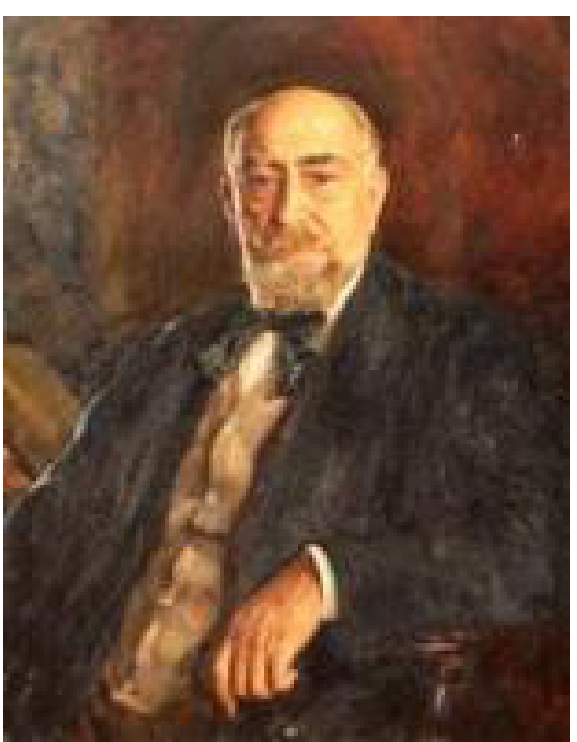

É importante salientar que ainda não havia nenhuma preocupação - nem por parte de Severo, nem pela sociedade - quanto à preservação dos edifícios coloniais brasileiros, muitos dos quais estavam sendo demolidos para ceder lugar a novos edifícios ${ }^{1}$, conforme estabelecido nos Planos de Melhoramentos da maioria das cidades (PINHEIRO, 2011, p.25). A concepção de Severo referente à valorização do passado colonial não estava ancorada no respeito à materialidade dos edifícios, mas nas informações que eles eram capazes de transmitir para a criação de uma nova arquitetura (PALAZZO, 2017, p.13). Desta forma, não é debatido, neste primeiro momento, a Figura 56: Ricardo Severo Fonte: preservação de edifícios como elementos transmissores Wikipédia. da cultura passada para as gerações presentes e futuras.

Em 1917, Severo ministra uma conferência sobre arquitetura religiosa brasileira no Grêmio Estudantil da Escola Politécnica de São Paulo, na qual, apesar de apresentar uma divisão em grupos anacrônicos e com alguns equívocos referentes a certos edifícios (PINHEIRO, 2011, p.46), evidenciou a qualidade das igrejas coloniais brasileiras, destacando sua originalidade,

1 Sobre a arquitetura que vinha sendo empregada na construção dos novos edifícios, Severo aponta: curioso é que, existindo nos outros países, mais cultos, essa orientação nacionalista que visa a perfeita cristalização da nacionalidade, o que deles se importa hoje de último estilo ou escola, em belas artes ou belas letras, tem esse fundo original tradicionalista. Melhor fora, pois, reproduzir a própria tradição do que a alheia (SEVERO apud. PINHEIRO, 2011, p.39.). [grifo nosso] 
e pertinência para estudos a serem conduzidos através da investigação direta, própria da etnografia e da arqueologia (PINHEIRO, 2017). Seus escritos, que extrapolaram o ambiente acadêmico, foram responsáveis por suscitar, nos mais diversos profissionais, o interesse pela arquitetura brasileira dos primeiros séculos, configurando desta forma o movimento Neocolonial.

Dentre os intelectuais motivados pelas palestras de Severo, encontra-se o jovem escritor e futuro defensor do patrimônio, Mario de Andrade, que irá realizar inúmeras viagens e publicar diversos artigos sob o título Arquitetura Religiosa Brasileira ${ }^{2}$, bem como condenar e denunciar a decadência da arquitetura religiosa brasileira nas primeiras décadas do século XX. Da mesma forma que Severo, Mário de Andrade não irá, naquele momento, criticar a demolição dos edifícios coloniais em São Paulo dizendo: "neste orgulhoso estado de São Paulo, que se não podia, com justiça, contentar-se com as velhas igrejas, pardieiros a esfrangalhar-se, foi necessário substituir tudo" (ANDRADE. apud. PINHEIRO, 2011, p.56), porém continuará condenando a execução de projetos em estilos que não são provenientes do Brasil:

Onde fomos buscar inspiração? Em Portugal, que nos deu o que possuímos? Ou nos progressos dessa dádiva, realizados na vastidão do Brasil? Nada disso. Queríamos ser progressistas, reformadores, cubistas, fomos buscar o que não era nosso, imitamos sem altivez, copiamos sem engenho (ANDRADE apud. PINHEIRO, 2011, p.56).

O expressivo número de igrejas que estavam sendo construídas ou reformadas na época, especialmente na cidade de São Paulo, fomentaram as denúncias de Mário, que se mostrava preocupado com o modo de construção e com o futuro dessas igrejas, que comparou a "velhotas faceiras e pobretonas: uma imitação, lacrimável, embranquecida a polvilho, enfeitada, com diamantes de mil réis, um erro nosso de construir igrejas nos mais estrangeiro dos estilos" (PINHEIRO, 2017).

Como solução, Mário de Andrade endossava as sugestões de Ricardo Severo de se estudar os componentes da arquitetura colonial, que definia ser "um tesouro abandonado onde os artistas poderiam ir colher motivos de inspiração" (PINHEIRO, 2017), e empregá-los na construção de novas igrejas, criando assim uma identidade para a arquitetura religiosa nacional. O escritor considerava, ainda, que a Igreja deveria se valer das artes e da arquitetura como instrumentos para educação e edificação do povo cristão.

As discussões e as publicações deste período (como as já citadas), relativas à busca de uma identidade nacional acabaram instigando vários profissionais a aderir aos ideais de retomada

2 Série de artigos públicos em 1920 na Revista do Brasil. (PINHEIRO, 2011. p.51.) 
da tradição e a aplicarem-nos em seus projetos de arquitetura. O próprio Ricardo Severo executou diversos projetos associando as mais arrojadas e modernas técnicas construtivas com ornamentação inspirada nos edifícios coloniais, dispondo da colaboração de José Wasth Rodrigues $^{3}$, outro profissional entusiasmado com a causa, que realizou um levantamento gráfico de elementos da arquitetura colonial brasileira.
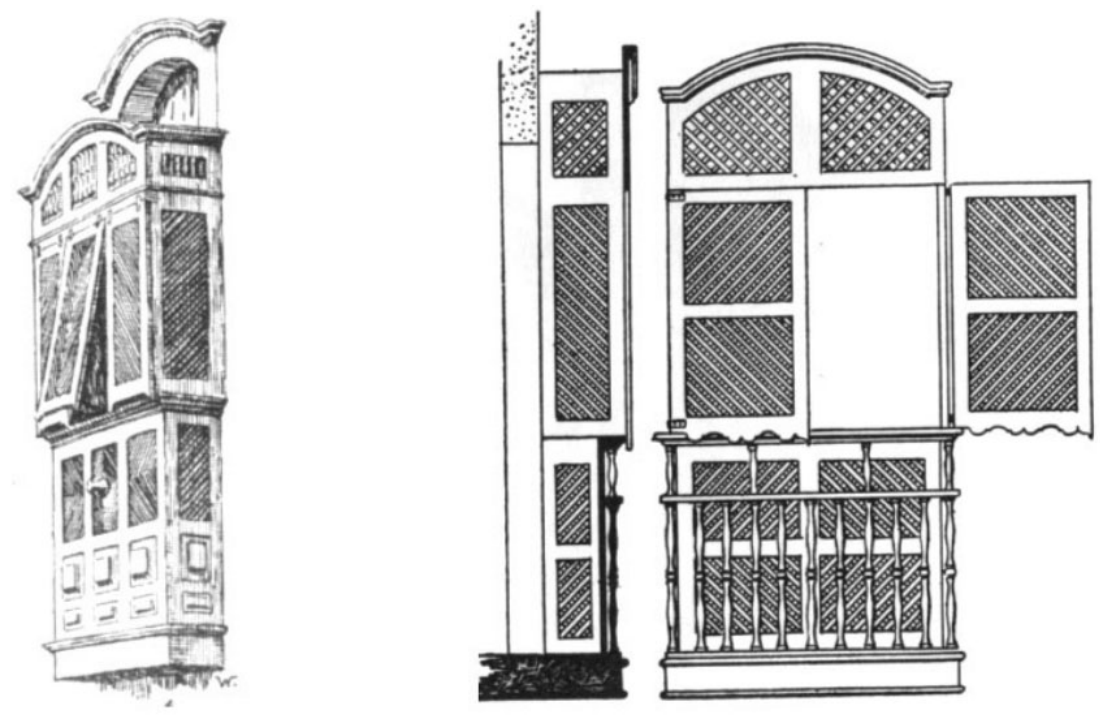

Figura 57: Desenhos de estudo de um muraxabi de José Watsh Rodrigues. Fonte: RODRIGUES, 1979, p.163.

Neste sentido, é válido destacar também a atuação de José Mariano Carneiro da Cunha Filho ${ }^{4}$, importante membro da elite pernambucana que será um fiel defensor dos ideais neocoloniais no Rio de Janeiro, onde irá publicar uma série de artigos em jornais (ATIQUE, 2011, p.174), tecendo críticas à arquitetura praticada então, especialmente ao ecletismo, e enaltecendo a busca por uma "arquitetura tradicional brasileira", que, mesmo sendo uma construção nova, deveria apontar para a "recuperação dos elos do passado" (ATIQUE, 2011, p.176). José Mariano Filho foi também o responsável por financiar diversas viagens de estudo e registro da arquitetura colonial do Brasil, em busca da consolidação de um repertório que pudesse colaborar na criação de uma arquitetura nacional (ATIQUE, 2011, p.176). Para Fernando Atique (2010), a expressão nacionalista difundida por José Mariano constituiria não apenas um estilo arquitetônico, mas um "projeto metodológico de cultura" através do espaço construído (ATIQUE, 2010, p.203).

3 José Wasth Rodrigues (1891-1957), pintor e desenhista é importante figura na difusão do neocolonial, sendo contratado por Ricardo Severo assim que retornou da França - onde realizou seus estudos - para executar uma série de desenhos e levantamentos acerca da arquitetura colonial Brasileira, realizando assim inúmeras viagens pelo Brasil desde 1918 e publicando em 1940 suas obras no livro: Documentário Arquitetônico.

$4 \quad J o s e ́$ Mariano da Cunha Filho (1881-1946), médico, aristocrata pernambucano e importante figura polêmica referente as questões culturais no Rio de Janeiro. Influente, se tornou presidente da Sociedade Brasileira de Belas Artes e possuía abertura para publicar suas opiniões em diversos em diversos jornais da época. Chegando também a ocupar a cadeira de diretor da Escola Nacional de Belas Artes (ENBA) entre 1926 e 1927. 


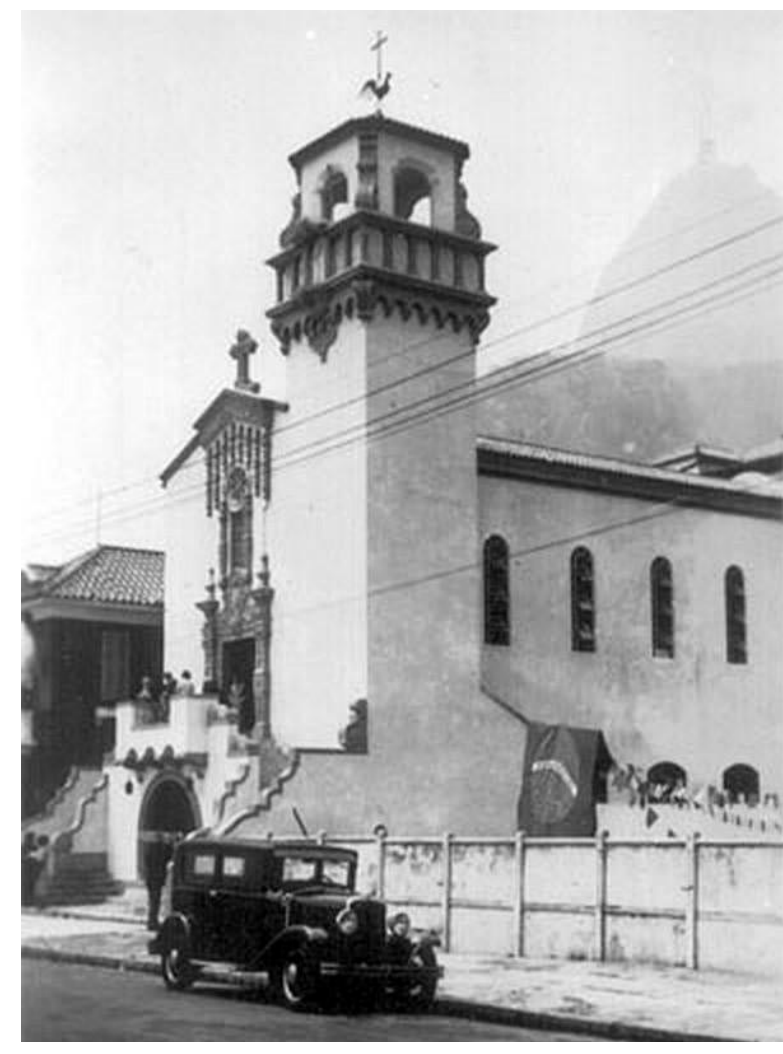

Gradualmente o estilo Neocolonial foi conquistando espaço entre profissionais brasileiros e sendo empregado na execução de diversos edifícios públicos e religiosos, além de projetos residenciais. Apesar de ser propagado como uma obra genuína brasileira, o neocolonial luso-brasileiro teve grande contato com matrizes hispano-americanas, e sua interação com o mission style(ou estilo missões) $)^{5}$ gerou uma arquitetura nova, com elementos próprios de uma linguagem pan-americana (ATIQUE, 2010, p. 223). É importante salientar que quase todo o continente americano, com exceção do Canadá, vivia um processo semelhante ao que acontecera no Brasil (ATIQUE, 2011, p.179).

Figura 58: Igreja Nossa Senhora do Brasil do Rio de Janeiro, projeto estilo missões feito por Frederico Faro Filho em 1925. Fonte: Igreja Nossa Senhora do Brasil

\section{O NEOCOLONIAL E A IGREJA}

No ambiente religioso, as motivações em busca da "Arte Tradicional do Brasil" encabeçadas por Severo e Mario de Andrade encontraram no clero ambiente propício para seu crescimento e difusão. Destaca-se, nesta questão, o papel de Dom Sebastião Leme, Cardeal Arcebispo do Rio de Janeiro (1921-1942), que, ao advogar em defesa do patrimônio artístico e sacro proveniente das igrejas - que estava se esvaindo em vendas e extravios indevidos-, assumiu também a causa do neocolonial (PINHEIRO, 2011, p.255). As orientações emitidas pelo prelado, publicadas nos mais diversos meios, enfatizavam, segundo os documentos da Igreja, qual era o papel dos párocos e capelães na administração dos bens de origem religiosa. Extrapolando o ambiente eclesiástico para o ambiente da cultura geral, o bispo afirmou que a arquitetura é a arte social por excelência, convergindo assim para o discurso

$5 \quad$ O estilo missões, ou missionstyle ou ainda "Renascença Espanhola" foi um movimento nascido nos Estados Unidos decorrente de sua expansão territorial no séc. XIX por áreas que eram de origem hispânica. Teve início a partir da construção de edifícios inspirados com os pertencentes das missões Franciscanas no Estado da Califórnia, que haviam sido extintas no passado pelo Governo Americano. Este tipo de estilo se difundiu por parte do Estados Unidos e México e chegou ao Brasil, através de um movimento pan-americano, instalando-se primeiro no Rio de Janeiro e depois sendo implantado em São Paulo (ATIQUE, 2010 e PINHEIRO, 2011). 
dos defensores do neocolonial, além de deixar clara sua opinião acerca da importação de estilos empregados nos edifícios religiosos:

Venham de fora os edifícios "arranha-céus", aclimem-se entre nós os métodos modernos de trabalho, indústria, comércio, agricultura, instrução e progresso. Adotem-se até se Ihes apraz, as modas e costumes nascidos e cultivados por influência de outros climas e sob a atuação de outros meios. Cultivem-se da literatura, artes e estilos arquitetônicos que corporificam ideais e aspirações, pensamentos e sentimentalidade que não são da alma brasileira. É uma incongruência sem nome, uma anomalia inconcebivel [...] ao nosso coração de brasileiro e sacerdote se impõe imperativo e urgente o dever patriótico de gritar uma e mil vezes que se respeitem ao menos os únicos tesouros e características nacionais que nos restam - as igrejas e seus objetos de arte. São relíquias da nossa fé, marcos da nossa nacionalidade, padrões gloriosos da nossa raça... (PINHEIRO, 2011, p.256). [grifo nosso]

E valendo-se da documentação da Igreja, afirma:

[...] já em 1659 a Congregação de Propaganda Fidei expressamente reprovava a pretensão de alguns missionários que para outros países tentavam transplantar usos e costumes de sua terra de origem. (Coll. n.135)

Ainda há 2 anos, a mesma Congregação, órgão supremo da Santa Sé para assuntos de missões, inquiria "se na construção e decoração dos edifícios sagrados dominam as formas de arte estrangeira ou se, como deve ser, se adaptam os missionários às notas e tradições locais [...] (PINHEIRO, 2011, p.256). [grifo nosso]

Discorrendo ainda sobre a construção de novos templos, o Arcebispo enfatiza que:

Não pretendemos, é óbvio, que se copiem edifícios de outras épocas, nem que cegamente se retroceda ao tipo do chamado estilo colonial. Julgamos, porém, não ser de mais pedir que, no estudo consciencioso das boas construções coloniais se procure aprender a sua força de expressão, a sua linquagem arquitetônica e decorativa, para bem exprimirmos, em nossa terra e em nossos dias, o pensamento cristão (PINHEIRO, 2011, p.256). [grifo nosso]

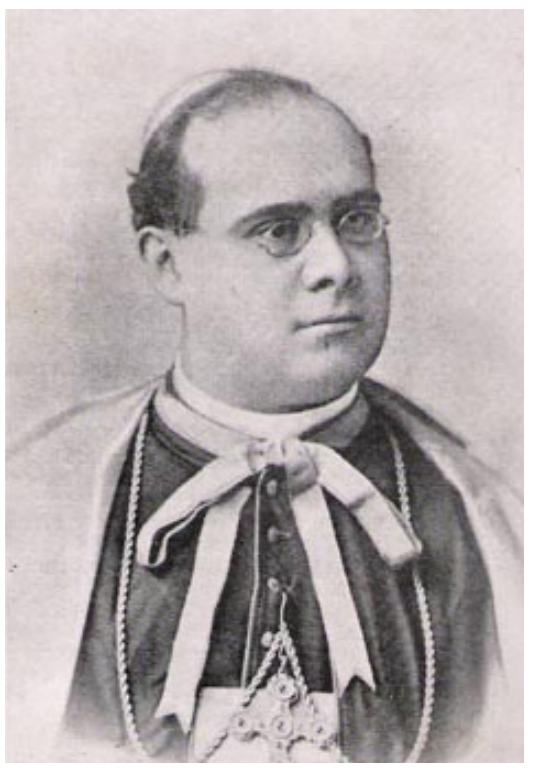

Assim, Dom Sebastião Leme deixava claro que não se deveria copiar ou retomar os edifícios coloniais, mas neles se inspirar para criar uma nova arquitetura voltada à nossa tradição, inserida dentro da modernidade, tanto em técnica construtiva, quanto em solução espacial.

Figura 59: Dom Sebastião Leme. Fonte: Wikipédia. 
Os discursos dos acadêmicos e profissionais, somados ao discurso do Clero, especialmente de uma figura proeminente no ambiente eclesiástico como a do Cardeal Arcebispo do Rio de Janeiro, demonstraram terem sido efetivos, no que se refere à produção de igrejas neocoloniais no Brasil, haja visto o número de igrejas construídas neste estilo só no território da Diocese de Limeira.

Sobre as igrejas que compõem este estudo, destaca-se que as mesmas foram projetadas e construídas em um período no qual o modernismo já tomava a frente de quase todas as construções realizadas, o que, segundo Carlos Lemos, indicaria o declínio da produção neocolonial, cuja importância foi diminuindo a partir da década de 30, quando passou a ser paulatinamente substituído pelo Art Déco, principalmente na cidade de São Paulo (LEMOS, 1994, p.160).

\section{IGREJA E MODERNIDADE: UMA RELAÇÃO CONFLITUOSA}

A Igreja, de maneira geral, teve dificuldades em se relacionar e lidar com o espaço e a estética proposta pelo modernismo, que se distanciava muito da imagem consolidada do espaço e da arquitetura sagrada desejada pela Igreja. A partir de 1930, será crescente o debate dentro do ambiente religioso em busca de uma nova expressão arquitetônica capaz de exprimir as necessidades da igreja inserida na modernidade (SILVEIRA, 2011, p.18). Segundo Silveira (2011), na época o modernismo era visto pela cúpula católica como expressão pagã e ligada ao comunismo, vertentes que deveriam ser combatidas e proibidas (SILVEIRA, 2011, p.27). Dessa forma, a aceitação do modernismo para a construção de novos templos seria uma abertura às questões tidas como mundanas dentro do ambiente religioso, um sinal de fracasso. O cenário só mudará a partir de 1965 quando a Igreja promulgará os documentos finais do Concilio Ecumênico Vaticano II, após um longo processo de estudos e reformulações de seus documentos basilares, que garantirão uma renovação da Igreja nas mais variadas questões, incluindo novas determinações para a liturgia e novas concepções para o espaço sagrado.

No entanto, no período que antecede ao Concilio Ecumênico Vaticano II, o embate entre a cúpula da Igreja e adeptos da arquitetura moderna fica muito claro nas recorrentes situações conflituosas geradas por projetos de igrejas modernistas, como aconteceu, por exemplo, na construção da Capela da Pampulha em 1936, considerada um dos marcos iniciais da arquitetura moderna religiosa brasileira, cuja construção, "não agradou" a Dom Antônio dos Santos Cabral, então Arcebispo de Belo Horizonte:

[...] edifício de tão aberrante concepção arquitetônica e decoração exótica, em flagrante contraste com o recolhimento e gravidade devem predominar nos recintos destinados à oração e celebração dos sagrados mistérios [...] (SILVEIRA, 2011, p.39). [grifo nosso] 
No entanto, o prelado decidiu consultar especialistas sobre o assunto para decidir sobre a sagração da igreja, cuja resposta, favoreceu o fato da igreja ficar 15 anos sem o ritual de consagração, sendo dedicada apenas em 1959.

[...] as instruções das Comissão Pontifícia de Arte Sacra, as tradições milenares da arquitetura cristã, nada disso entrou nas cogitações de quem mandou construir aquela geringonça. [...] Não tem forma de igreja coisa nenhuma. Essa deformidade serviu para achincalhar a ideia religiosa e metê-la a ridículo. Ao lado, está um troço largo em cima e estreito em baixo, numa inversão própria e muito apreciada pelos modernos. Isso é lá com eles [...]

Uma outra trapalhada é um fingimento de Cruz com a travessa transformada em poleiro ou assento confortável de onde satã pode conversar calma e confortavelmente com o sr. Kubitschek. Esse tipo de Cruz é completamente desconhecido desde a antiguidade até os nossos dias. É a cruz do kapeta...

Enquanto os comunistas, desenvolviam entusiástica propaganda dessa bobagem arquitetônica, para atingirem seus fins de destruírem o sentimento cristão do povo humilde, os tolos, com medo de serem descobertos como bestas, fingiam e fingem ainda, que entendem daquela moxifinada que não entendem (LIMA JÚNIOR apud. SILVEIRA, 2011, p.40).

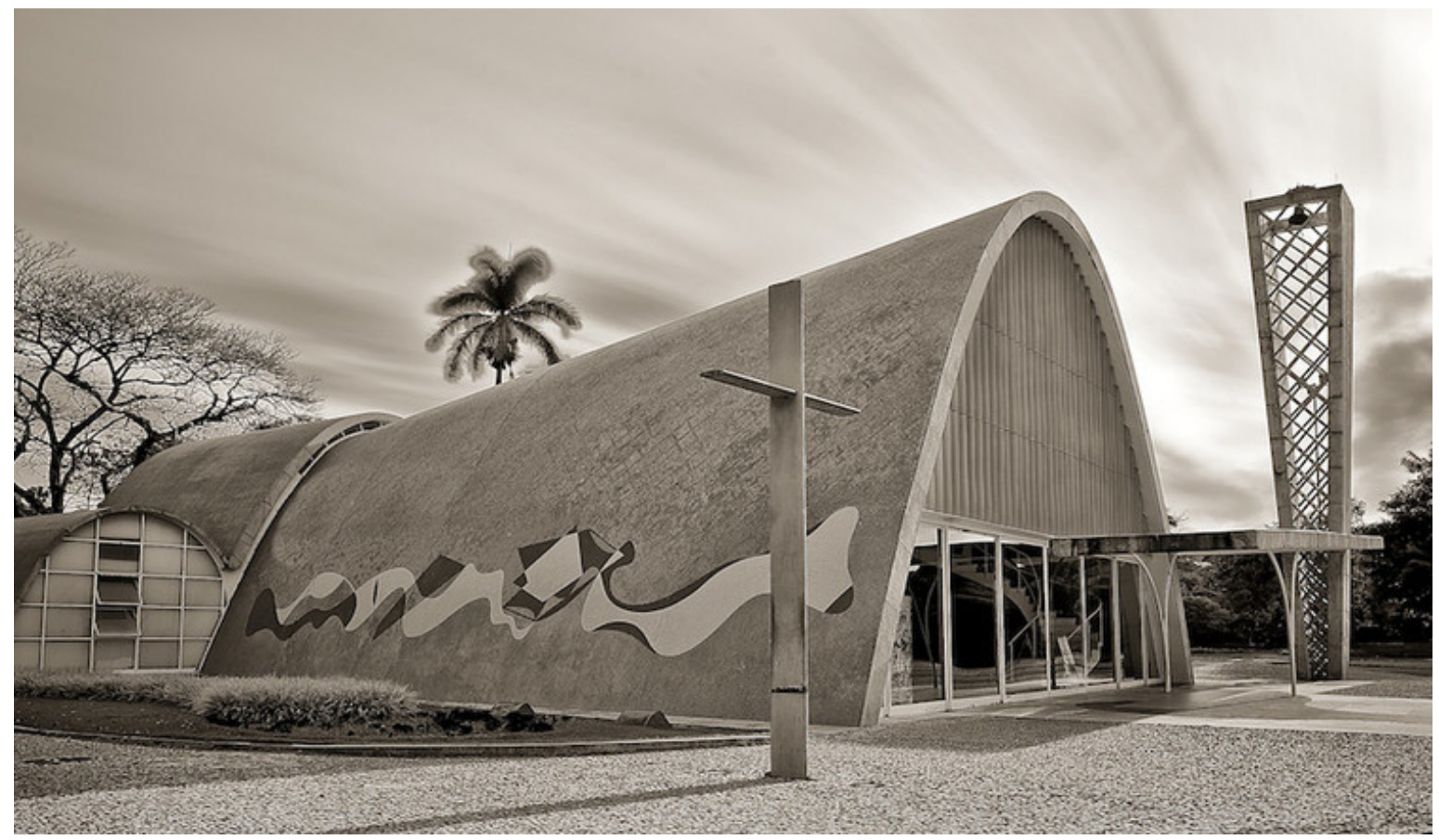

Figura 60: Igreja Sâo Francisco de Assis da Pampulha em Belo Horizonte. Projetada por Oscar Niemeyer e inaugurada em 1943 . Fonte: Archdaily.

O Neocolonial, ao contrário, parecia cumprir plenamente com o objetivo desejado para a construção de um novo templo, pois predominava na Igreja uma atitude triunfalista, que se ancorava na potencialidade simbólica dos estilos históricos de remeterem ao esplendor outrora alcançado por aquela instituição, sugerindo sua permanência no mundo moderno (SILVEIRA, 2011, p.19). Com isso, o Neocolonial assumiu certa representatividade para a tipologia religiosa, pois, além de ser ensinado em boa parte das escolas de arquitetura 
na época ${ }^{6}$, era comumente recomendado nas revistas e publicações católicas, como neste trecho do artigo assinado pelo Padre Bento de Sousa encontrado na Revista Eclesiástica Brasileira de setembro de1950:

Infelizmente, nós brasileiros menosprezamos e até nos envergonhamos de nosso primoroso estilo colonial. Dentre tantas Igrejas importantes construídas nestes últimos 50 anos no Brasil, é difícil encontrar uma em estilo colonial. [...] O estilo colonial, assim como todos os estilos, tem suas regras severas, as quais, observadas, encantam. Como é nosso, passou a ser relegado. [...] Entretanto, o colonial é o estilo que se adapta ao nosso clima e à nossa índole [...] Assim como os arquitetos da antiguidade aperfeiçoaram o românico e o gótico, procurem os nossos artistas aperfeiçoar o colonial. Façam-no evoluir de dentro de suas próprias linhas, endogem-no (desculpem o neologismo), adaptem-no às necessidades $e$ imperativos da época (cimento armado) e lugares (cidades...espaços limitados) e veremos que nenhum outro Ihe levará vantagem (SOUSA apud. SILVEIRA, 2011, p.49).

Nos casos onde foi adotado o neocolonial como estilo para as igrejas, os arquitetos passaram a realizar novas composições, como na instrução dada pelo Pe. Bento de Sousa. Surgiram novos modelos de plantas, novas proposições espaciais e até mesmo uma ornamentação muito diversificada das empregadas até o momento, além da utilização de novos materiais e técnicas construtivas que viabilizaram novas soluções estruturais, culminando na criação de uma arquitetura especifica e de edifícios únicos, como no caso das igrejas deste estudo, cujos exemplares serão apresentados a seguir.

\section{2 - UMA NOVA IGREJA PARA UMA NOVA CIDADE}

As cidades interioranas também buscavam se modernizar de acordo com os padrões implantados nas capitais. Muitas cidades realizaram planos urbanos de remodelação do sistema viário e novos loteamentos para comportarem o número de habitantes, que crescia exponencialmente com o êxodo rural e com o desenvolvimento de novas atividades sociais e fabris. A chegada de grandes indústrias e a consolidação de novas infraestruturas de transporte, como a construção das rodovias, especialmente a Rodovia Anhanguera (SP330), potencializaram o crescimento da região ao norte da então Diocese de Campinas ao longo do século XX.

Com o crescimento populacional, as cidades maiores tiveram suas paróquias desmembradas para garantir um atendimento contínuo a todo povo. Deste modo, foi se multiplicando o número de igrejas, capelas e paróquias, criando um território vasto e de difícil atendimento

6 Deve-se destacar nesse momento, a formação dos arquitetos e urbanistas na Escola Nacional de Belas Artes (ENBA) no Rio de Janeiro, Escola Politécnica de Universidade de São Paulo (USP) e a Faculdade de Arquitetura e Urbanismo da Universidade Presbiteriana Mackenzie em São Paulo, onde a difusão dos ideais de uma arquitetura nacionalista aconteceram de forma intensa através de profissionais professores aderentes ao neocolonial (ATIQUE, 2010). 
pelo bispo diocesano, uma vez que a própria sede do bispado e cidades circundantes passavam por um crescimento análogo. As paróquias buscavam se reestruturar para se inserirem na modernidade e comportarem adequadamente seus fiéis, cujo número crescia significativamente, conforme apontado no capítulo 02 (p.82).

Quase todas as cidades que hoje compõem a Diocese de Limeira oriundas do século XIX empreenderam obras em suas primeiras igrejas construídas. Tais empreitadas visavam a adequação dos templos e suas remodelações, destinadas a renovar esta tipologia significativa para às cidades. Assim, ao longo dos anos, as matrizes foram sendo ampliadas e reconstruídas, de acordo com o estilo da época, como já mostrado anteriormente no caso de Limeira.

Das paróquias criadas e construídas no século XIX, somente duas cidades não demoliram suas matrizes ao longo do século XX: Araras, que realizou apenas obras internas na sua matriz de $1881^{7}$ em 1912 e em 1974; e a cidade de Analândia, que não realizou nenhuma reforma substancial em sua matriz de 1887 até os dias atuais.

As cidades de Pirassununga, Descalvado e Cordeirópolis realizaram obras de reconstrução e ampliação de suas matrizes no início do século XX. A Igreja Matriz do Senhor Bom Jesus dos Aflitos de Pirassununga teve sua reconstrução iniciada em 1895, porém só concluída em 1929, quando, a partir de uma fusão de estilos e ornamentos, se tornou um edifício eclético. A mesma concepção arquitetônica foi utilizada na reforma e ampliação da igreja de Cordeirópolis, em 1906, e na reconstrução da de Descalvado, em 1925.

Já as cidades da região do Funil construíram suas primeiras matrizes ou capelas já no século $X X$, cujos edifícios ${ }^{8}$ são os mesmos até os dias atuais. Além de Cosmópolis, que compõe este estudo, apenas Engenheiro Coelho construiu uma igreja nova ${ }^{9}$ na década de 60.

Algumas cidades optaram por reconstruir suas igrejas principais na metade do século XX, como as cinco que compõem este estudo, cujas matrizes foram reconstruídas em neocolonial. Além delas, Americana empreendeu obras para construir uma nova matriz ${ }^{10}$ em 1950. Nova

$7 \quad$ A atual Basílica Nossa Senhora do Patrocínio de Araras teve sua construção comandada pelo construtor Tristão Franklin de Alencar. Sua fachada possui detalhes que lembram a Basílica Papal de São João Latrão, e seu interior possui pinturas do pintor esloveno Francisco Pavlovic.

8 As cidades de Artur Nogueira e Conchal são exemplos de cidades que ainda possuem igrejas com a tipologia religiosa clássica difusa por todo interior paulista, com pequenas dimensões, torre sineira central, planta retangular e ornamentação simplificada. Atualmente a igreja de Artur Nogueira passa por uma reforma. 9 O projeto foi realizado pelo Eng. Otávio Siqueira com recomendação do bispo diocesano de Campinas, Dom Paulo de Tarso Campos, por se tratar de um profissional experiente na área. Para a construção da nova igreja foi empregado o estilo moderno e não foi necessário demolir a primitiva capela de São Pedro de 1936, pois foi doado um lote para este fim em um novo loteamento que estava sendo realizado. É válido lembrar que a Paróquia São Pedro de Engenheiro Coelho ainda não existia, pois, a mesma só foi criada em 29 de junho de 2000, portanto a nova igreja não se tratava de uma nova matriz, mas sim da construção de uma capela maior. 10 A nova matriz de Americana foi construída por Lix da Cunha duas quadras acima da primeira Igreja de Santo Antônio, sem ser necessária sua demolição. A nova matriz, atual Basílica Santo Antônio, é o maior templo neoclássico da América Latina e possui pinturas e esculturas dos irmãos Pedro e UldoricoGentille. 
Odessa, uma cidade majoritariamente protestante, que havia construído sua primeira capela somente em 1948, substituiu sua ermida por uma nova igreja em $1964^{11}$.

No que se refere à arquitetura moderna, apenas a cidade de Leme demoliu sua antiga matriz eclética para dar lugar a um projeto modernista. A antiga matriz, construída na virada do século e reformada na década de 30, foi ao chão sob argumentação do pároco de que sua estrutura estava muito alterada e comprometida tecnicamente. Apesar dos protestos contrários à sua substituição, a nova matriz, com projeto de autoria de Joaquim Olavo Sampaio, teve sua pedra fundamental lançada em 1962. A construção- que começou em 1963 sob os cuidados da construtora Lix da Cunha S.A-, ficou pronta em 1968. Além de Leme, Cordeirópolis, que havia reformado sua matriz no início do século, remodelou totalmente sua igreja em 1961, transformando o antigo arcabouço eclético numa igreja de feições modernistas ${ }^{12}$.

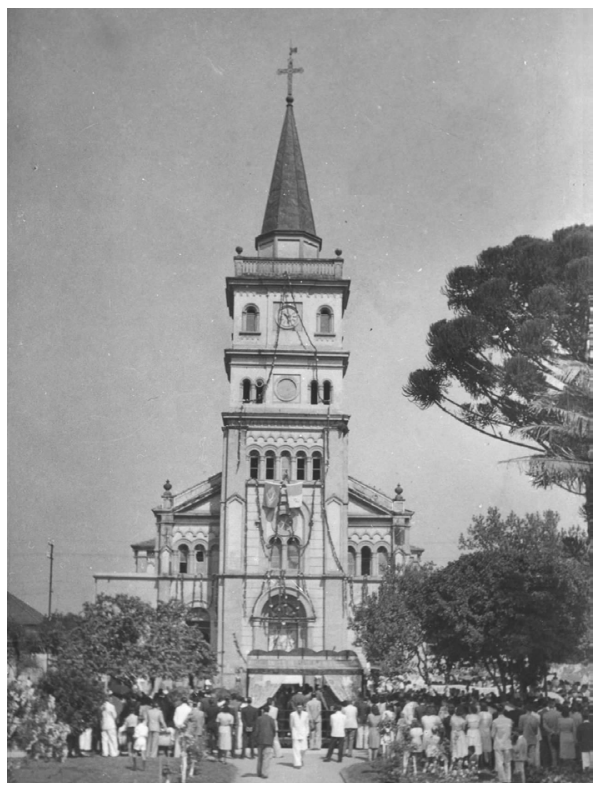

Figura 61: Antiga Matriz São Manoel de Leme na década de 30. Fonte: Acervo do Museu Histórico de Leme.

Figura 62: Nova Matriz São Manoel de Leme construída na década de 60. Fonte: Diocese de Limeira.

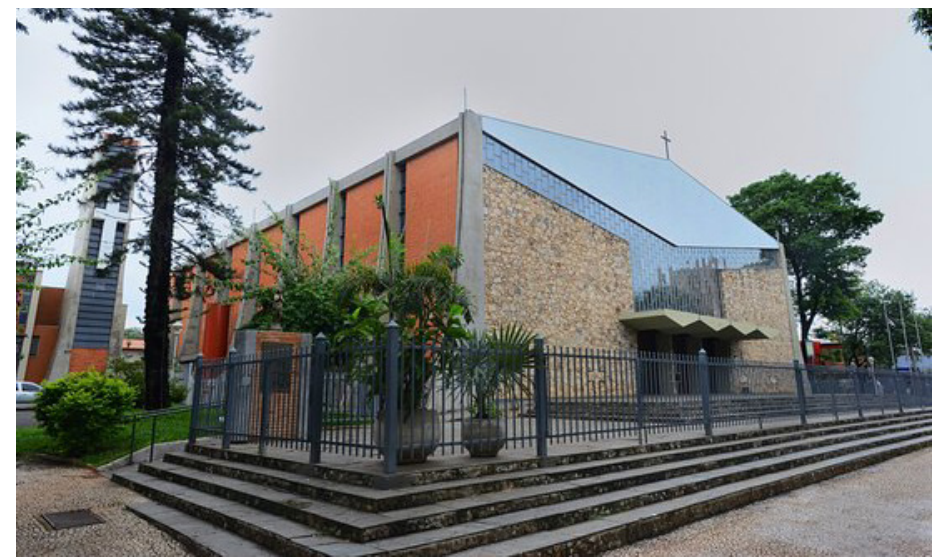

11 A nova matriz de Nova Odessa foi projetada por Joaquim Olavo Sampaio, profissional atuante na região na construção de igrejas. Veremos mais sobre sua atuação no item referente a Igreja de Jesus Crucificado de Iracemápolis.

12 A antiga igreja também eclética de Cordeirópolis foi totalmente reformada e transformada em moderna. Os altares internos foram removidos, os ornamentos da fachada tirados, e uma nova torre construída conjunta a uma marquise na porta principal. 


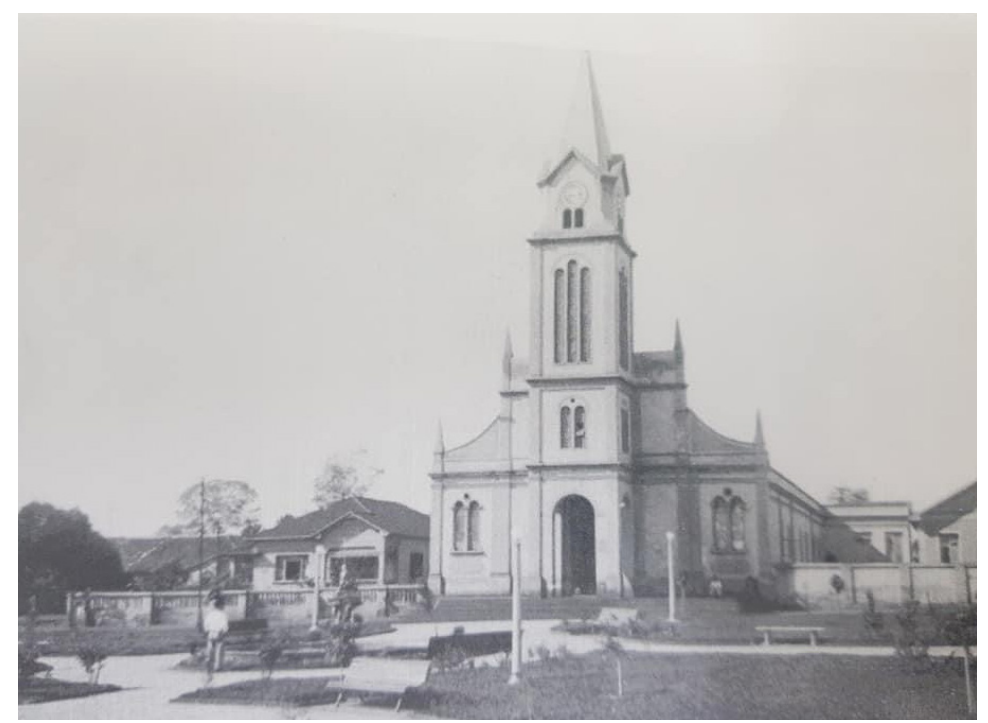

Figura 63: Igreja Matriz Santo Antônio de Cordeirópolis em 1909. Fonte: Acervo da Paróquia Santo Antônio.
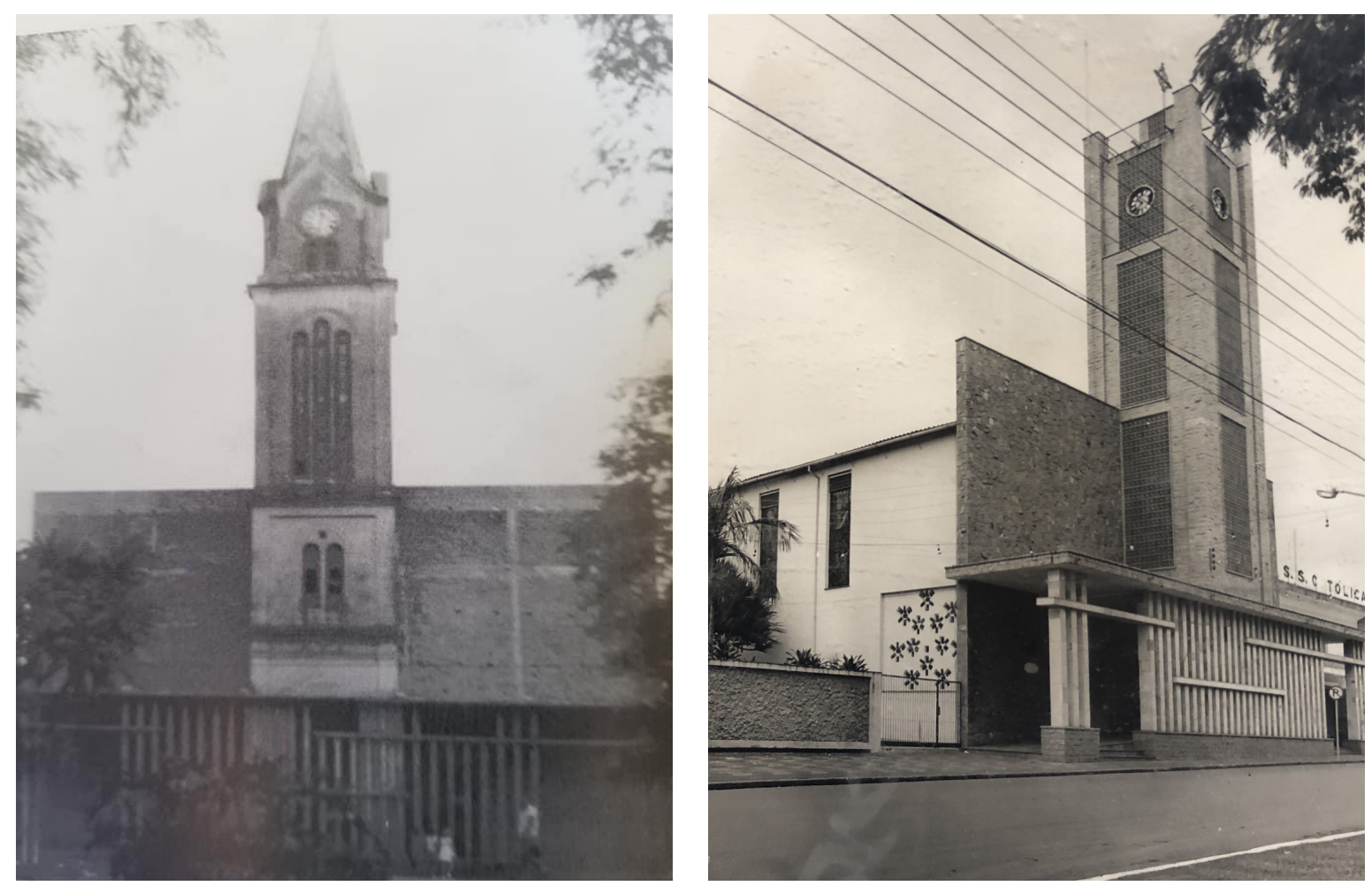

Figuras 64 (esquerda): remodelação da Igreja Matriz de Cordeirópolis na década de 60, com a transformação de seu arcabouço eclético para um de feições modernas, e Figura 65 (direita): Igreja totalmente transformada já na década de 90. Fonte: Acervo da Paróquia Santo Antônio e acervo da Cúria Metropolitana de Campinas.

Estes casos exemplificam a dinâmica pela qual passava a região na transformação e na construção de novos templos, decorrentes do crescimento das paróquias e o desenvolvimento econômico e social da região. Tais questões serão aprofundadas a seguir, onde serão apresentadas as condicionantes e os processos antecedentes pelos quais passavam as 5 paróquias deste estudo, que culminaram nas reconstruções de suas matrizes em Neocolonial. Como já apontado nos capítulos anteriores, todo o crescimento vivenciado 
na região, permeado por múltiplas nuances e incidências, fomentou o desmembramento territorial da Arquidiocese de Campinas ${ }^{13}$ e da Diocese de Piracicaba ${ }^{14}$ em 1976, ocasionando a criação da Diocese de Limeira.

\section{DO NEOGÓTICO PARA O NEOCOLONIAL: OS PROJETOS DE MARIO PENTEADO PARA A MATRIZ DE LIMEIRA}

A Igreja Matriz de Limeira que, como apontado no capítulo 02 (p.86), havia sido construída em 1876 e parcialmente reformada na década de 30, necessitava de obras de finalização e reparo. A estabilidade da parte da estrutura da igreja que ainda não havia sido reformada anteriormente era motivo de preocupação para o novo pároco, Cônego Manoel Alves, que em 1940 contratou o arquiteto Mário Penteado para a elaboração de um estudo para a nave e a fachada principal, que deveria incorporar a parte que já havia sido remodelada. Em carta endereçada ao bispo de Campinas, Dom Paulo de Tarso Campos, oito anos depois, Mario Penteado relata que este primeiro estudo, concebido apenas para a manutenção do templo e seu embelezamento, respeitando a área primitiva construída, não chegou a ser executado em parte alguma (PENTEADO, 1952, p.01).

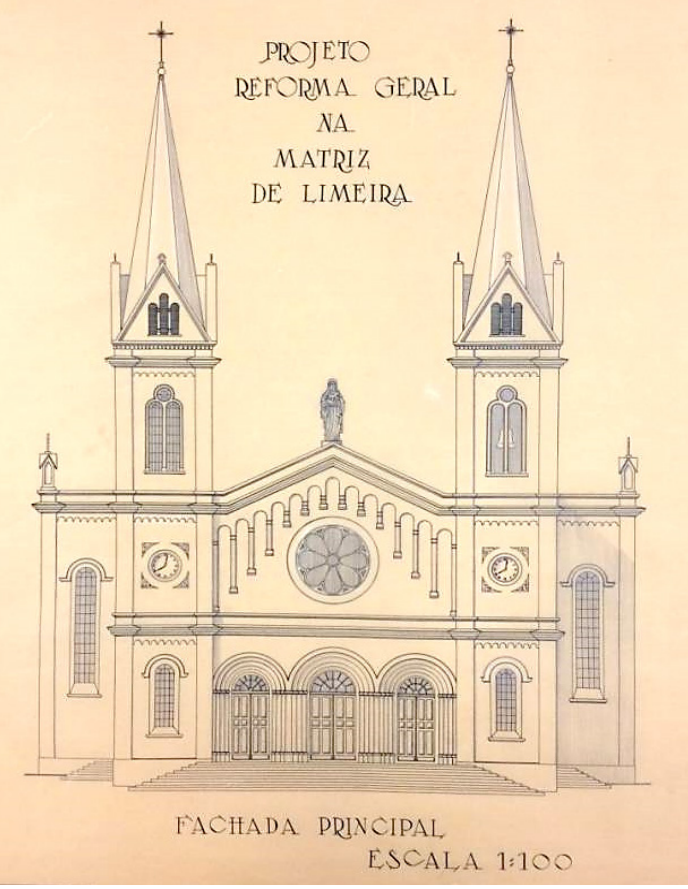

Figura 66: Fachada principal do primeiro estudo da Matriz de Limeira desenvolvido por Mario Penteado no ano de 1940. Fonte: Centro de Apoio Acadêmico da PUC Campinas.

13 A Diocese de Campinas foi elevada ao grau de Arquidiocese em 1958, criando desta forma a Província Eclesiástica de Campinas. Além de Campinas, as Dioceses de São Carlos, Bragança Paulista e Piracicaba compunham a província inicialmente. As Dioceses de Limeira e Amparo foram anexadas quando criadas em 1976 e 1997, respectivamente.

14 A Diocese de Piracicaba foi criada em 1944. Analândia e Cordeirópolis são as únicas cidades desmembradas de seu território para compor a Diocese de Limeira. 
O estudo, que assumia linhas do neogótico, foi concebido em um período que pode ser considerado tardio para o emprego deste estilo, que já não costumava ser muito utilizado em construções religiosas. Dentre os fatores que podem ter motivado Penteado a adotar o neogótico como opção para a igreja de Limeira, pode-se apontar as obras em andamento da construção da Catedral da Sé de São Paulo, projeto de Maximilian Hehl, iniciadas no ano de 1913 e que se alongariam até o ano de 1954. O modelo de uma grande igreja neste estilo, no centro de uma cidade desenvolvida, pode ter inspirado o arquiteto a reproduzir tal arquitetura em Limeira.

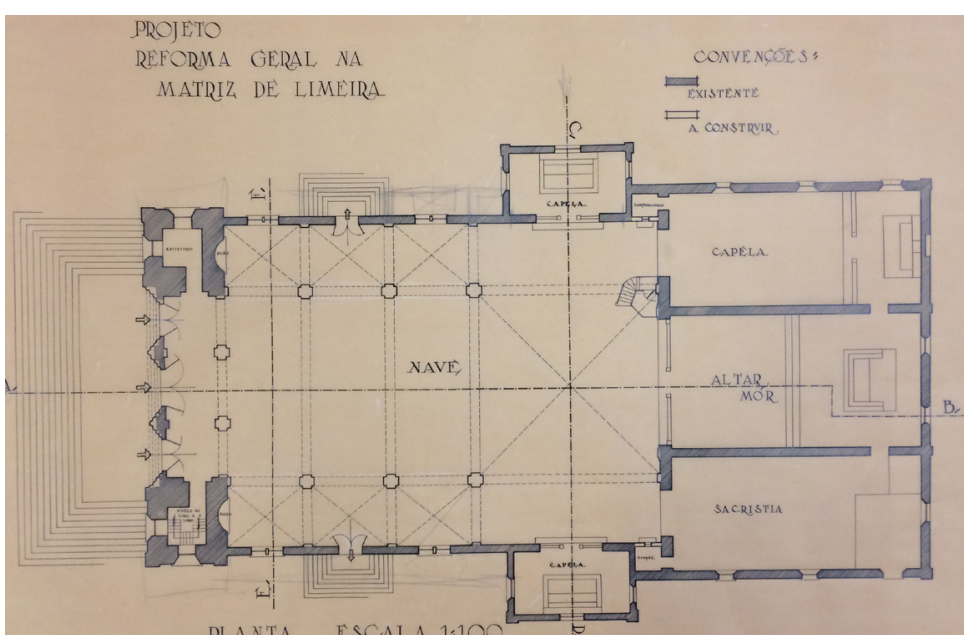

Figura 67: Planta do primeiro estudo para a Matriz de Limeira feito por Mario Penteado no ano de 1940. Pode-se notar as paredes da área que deveria ser mantida, devido as recentes reformas, e a capela lateral, projetada da elevação. Fonte: Centro de Apoio Acadêmico da PUC Campinas.

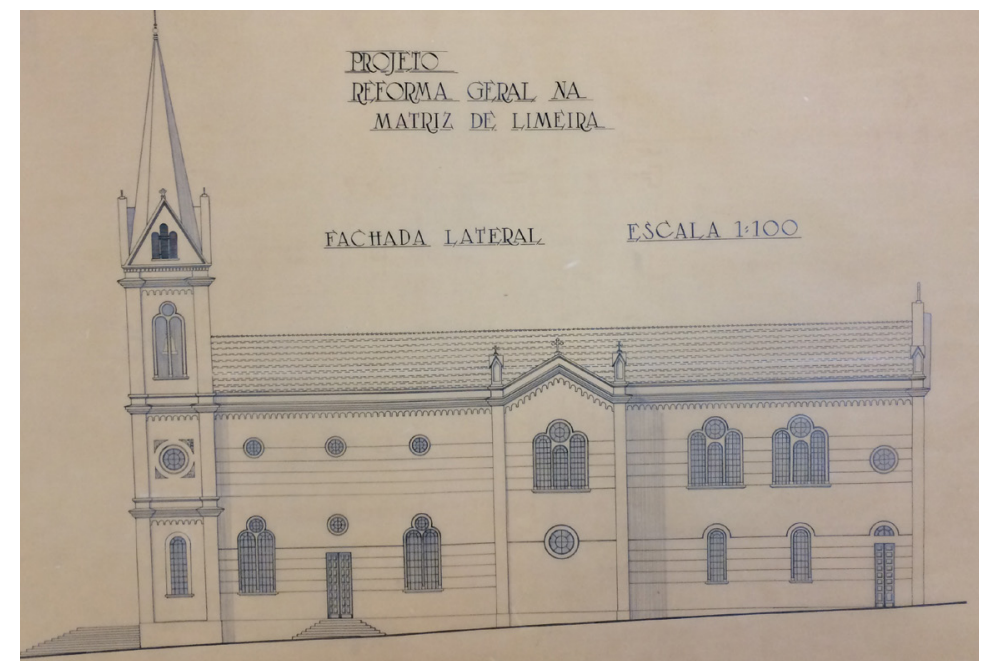

Figura 68: Elevação lateral do estudo de 1940 desenvolvido por Mário Penteado. Fonte: Centro de Apoio Acadêmico da PUC Campinas

Contudo, era de interesse da população e da cúpula eclesiástica a conclusão das obras de reforma da igreja Matriz, que não poderia ficar como estava. Os entraves que dificultavam a conclusão da empreitada pareciam se acumular. Em 1945, a Prefeitura Municipal chegou a propor um auxílio para a conclusão das obras, cuja autorização deveria ser dada pelo Presidente da República, através da Comissão de Estudos dos Negócios Estaduais (TOMBO IV. NSD. p.120). Porém, o auxílio não foi aprovado, fazendo com que a igreja continuasse 
metade reformada e metade deteriorada, questão que, com o avançar dos anos, se tornava cada vez mais problemática.

Na vista pastoral de 1946, o bispo exalta o empenho do pároco em conseguir recursos para a finalização das obras e expressa a necessidade de se concluir o projeto realizado para a igreja:

São também dignos de nosso aplausos e benção os esforços do Reverendíssimo Cônego Luís de Abreu, provendo os recursos necessários para a restauração completa da velha Igreja Matriz de Nossa Senhora das Dores. Esse trabalho, já encomendado pelo nosso venerado antecessor e nós mesmos em nossa primeira visita, hoje trata-se urgente. O primeiro templo da cidade já não corresponde ao progresso acelerado de Limeira e às necessidades espirituais de seu grande e piedoso povo (TOMBO IV. NSD. p.128).

O que se entendia por conclusão das obras, era finalizar o projeto realizado por Agostinho Balmes Odísio, em 1928. O estudo realizado por Mario Penteado foi encomendado, mas não utilizado. Os registros dão a entender que o projeto original de remodelação da igreja não agradava aos párocos e suscitava preocupações quanto a questões estruturais. Contudo, como já havia sido utilizado muito dinheiro para a execução da primeira parte da reforma, tornava-se inviável propor ao povo mais uma mudança. No entanto, o prosseguimento das obras, além das dificuldades financeiras, esbarrava em problemas técnicos, suscitando grande preocupação entre os profissionais envolvidos.

Em março de 1948, o arquiteto Benedito Calixto Neto, especialista na construção de igrejas e assessor técnico da Comissão de Arte Sacra da Arquidiocese de São Paulo, é chamado a Limeira para dar seu parecer sobre a continuidade das obras da Igreja Matriz:

As obras da lgreja Matriz acham-se interrompidas há quase 20 anos. Desejando ir de encontro ao ideal dos católicos de Limeira [...]. Atendendo ao pedido que V. R. para um parecer meu quanto a conveniência de uma reforma e prosseguimento das atuais obras da Igreja Matriz de Limeira, levo ao seu conhecimento que, como resultado da visita que fiz a referida igreja e exame do projeto de reforma em parte executado, meu parecer é que, nem um novo projeto e nem o prossequimento das atuais obras são convenientes. O estado atual do edifício da Igreja Matriz de Limeira não permite um aproveitamento compensador do que existe. Nada encontrei na referida igreja que merecesse um aproveitamento, que sob o ponto de vista da tradição, que sob o ponto de vista da arte. Quanto a tradição, o edifício está por demais mutilado em suas linhas originais, nada restando da primitiva igreja senão algumas paredes. Quanto a parte artística, nada encontrei que valesse a pena um aproveitamento ou conservação. Também a reforma projetada e em parte executada, sou de parecer que deve ser abandonada, pois contém defeitos graves (TOMBO IV. NSD. p.137). [grifo nosso] 
Além do arquiteto Benedito Calixto, o engenheiro-arquiteto Lix da Cunha ${ }^{15}$ foi chamado à cidade para dar seu parecer sobre o edifício (TOMBO IV. NSD. p.139). O resultado, que endossou os argumentos de Calixto, foi apresentado na reunião da comissão de obras, gerando descontentamento em boa parte dos participantes, que exaltavam as qualidades da igreja e o apego que tinham com sua antiga matriz, especialmente com a capela do Santíssimo, recentemente reformada.

As manifestações em favor da capela, cuja obra fora bastante custosa, motivaram o pároco a pedir um novo projeto para o arquiteto Mário Penteado, considerando que deveria fazer "um projeto e planta, aproveitando a Capela do Santíssimo, mas reformando a capela-mor e a sacristia" (TOMBO IV. NSD. p.140v). Como em seu primeiro estudo, Penteado mantém o estilo neogótico, porém sugere uma expansão do templo. O projeto foi aprovado pelas autoridades eclesiásticas e civis, e a sede da paróquia foi transferida novamente para a Capela da Boa Morte para que se iniciassem as obras da nova reforma.

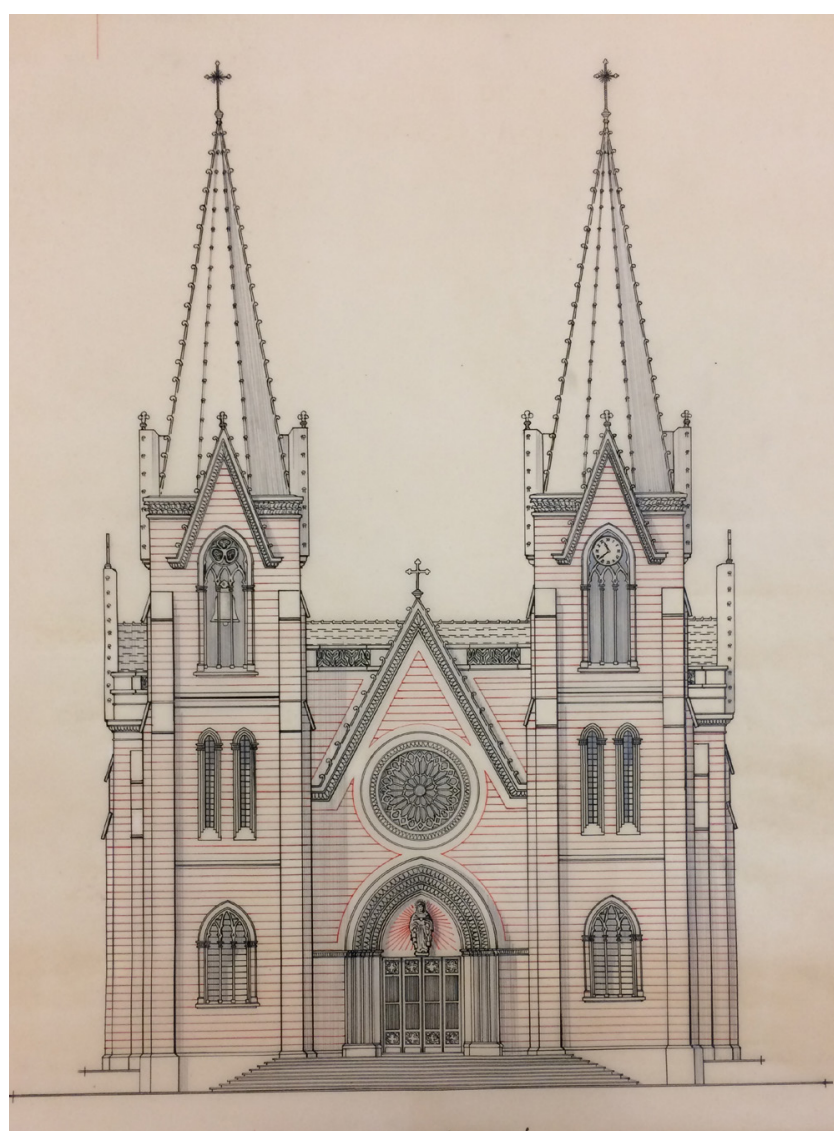

Figura 69: Elevação principal do projeto desenvolvido por Mário Penteado em 1948. Nota-se uma ornamentação mais expressiva e detalhada, aproximando-se ainda mais do neogótico. Fonte: Centro de Apoio Acadêmico da PUC Campinas.

15 Lix da Cunha. (Mogi Mirim, 1896 - Campinas, 1984). Engenheiro-arquiteto formado nos Estados Unidos e com escritório grande porte estabelecido na cidade de Campinas. Lix da Cunha foi autor de inúmeros projetos na região, inclusive, como já apontado a Basílica Santo Antônio de Pádua de Americana. 
Figura 70: Planta do projeto de Mario Penteado de 1948 com expansão da nave da Igreja e remodelação total da fachada.Fonte: Centro de Apoio Acadêmico da PUC Campinas.

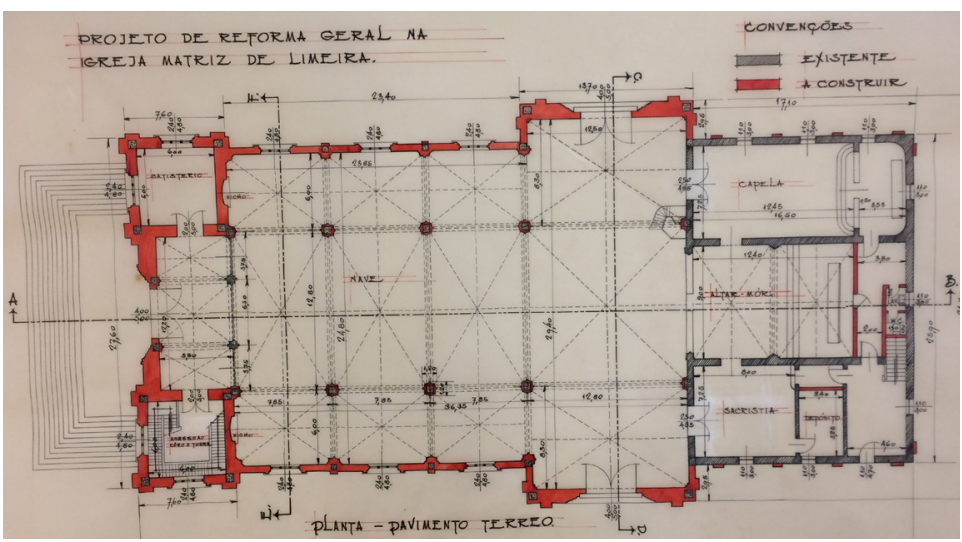

Figura 71: Elevação do projeto de Mario Penteado de 1948. Fonte: Centro de Apoio Acadêmico da PUC Campinas.

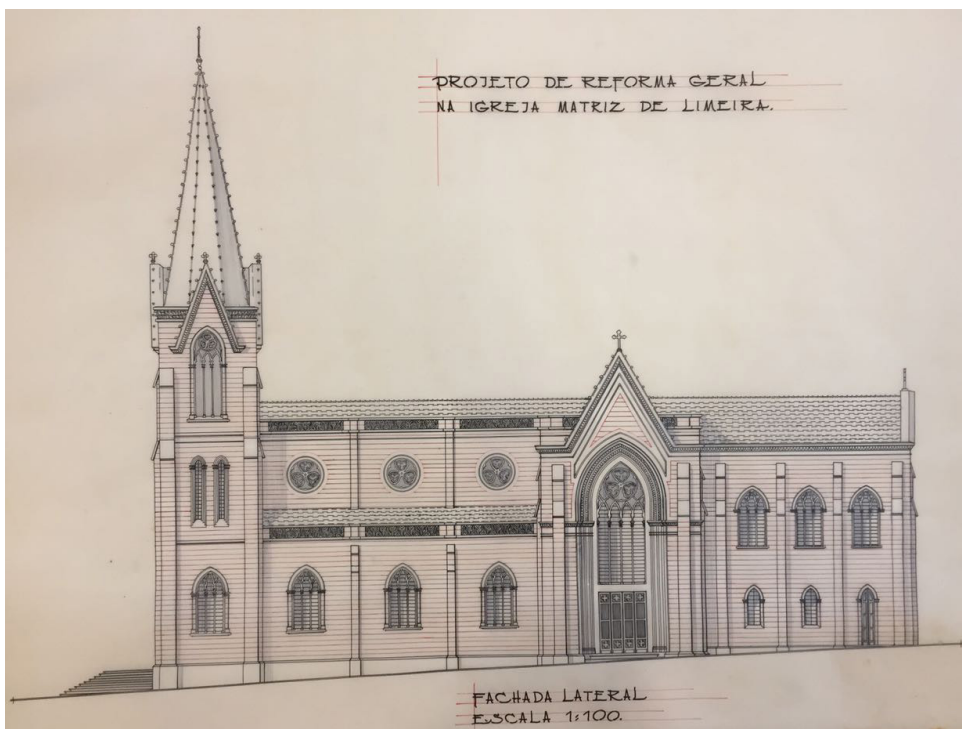

O início da demolição da parte antiga da Matriz contou com solenidades e ritos para marcar a ocasião. Os sinos foram tocados após a última missa celebrada, sendo um deles retirado e descido até o chão, defronte à maciça população que assistia e se despedia de sua Igreja Matriz. Os trabalhos de demolição da parte a ser removida da antiga igreja começaram, e todo material que era possível ser reaproveitado foi guardado, ou vendido para angariar fundos para as obras.

Com a demolição das partes a serem subtraídas, o arcabouço remanescente continuou a ser motivo de preocupação por parte dos responsáveis técnicos. A solução desejada por estes era de que toda a velha igreja deveria ir ao chão para dar lugar a uma nova matriz. Com isso, a cidade ficou dividida entre dois grupos, que foram intitulados de "derruba" ou "não derruba". Um grupo, que preconizava a conservação das estruturas antigas, defendia a valorização da tradição e do patrimônio da cidade, e o outro grupo, considerado progressista, anunciava que a velha matriz nada tinha a oferecer no quesito beleza e arte sacra, e nem sequer servia de "símbolo para a cidade que Limeira estava se tornando e seria objeto de orgulho dos limeirenses" (TOMBO V. NSD. p.56). 
Com o crescimento e expansão da cidade de Limeira, as autoridades limeirenses buscavam consolidar uma igreja que ostentasse o desenvolvimento pelo qual a cidade vinha passando. Além disso, o poder eclesiástico estudava um possível desmembramento territorial da região, devido às dificuldades enfrentadas pelo bispo de Campinas em atender a porção mais ao norte da Diocese. Neste cenário, Limeira figurava como a melhor cidade da região para se tornar a sede de um futuro bispado, fato que motivou boa parte da população que outrora defendia a manutenção das velhas estruturas da igreja matriz a mudar de ideia, e pleitear um novo templo.

Na carta ao bispo diocesano de 28 de março 1952, Penteado afirma que - tal como os outros profissionais que haviam emitido pareceres -, não encontrava na igreja nenhum bem de valor arquitetônico e artístico, e que, prevendo os futuros usos, decidiu executar um terceiro projeto, abandonando o neogótico e partindo para o Neocolonial (PENTEADO, 1952, p.02).

Segundo publicação da "Revista Ilustrações Brasileiras" do Ano Santo de 1950:

Uma nova Igreja Matriz surgirá dentro de poucos anos para a glória de Limeira e orgulho de seu povo. [...] A futura Igreja Matriz, cujo projeto mereceu a aprovação prévia do Bispo de Campinas, Dom Paulo de Tarso Campos, obedece a um estilo colonial de belas proporções e sua ereção será a mais positiva afirmação dos sentimentos cristãos e da cultura do povo de Limeira (TOMBO V. NSD. p.57). [grifo nosso]

Pouco a pouco, o sentimento de apego para com a velha igreja foi ficando de lado e a população limeirense aderiu à causa de uma nova matriz. O discurso de que uma nova igreja era necessária para exaltar Limeira como uma cidade destinada ao progresso ganhou forças com a escolha de uma data para a celebração da colocação da pedra fundamental, que contaria com a presença de autoridades eclesiásticas, civis e representantes de segmentos do povo. Em 29 de julho de 1951, a "Gazeta de Limeira", publicou uma reportagem que anunciava as solenidades, e dizia que "Limeira terá um templo à altura de suas tradições, seu majestoso templo principal, um dos mais imponentes da Diocese de Campinas" (TOMBO V. NSD. p.66).

A cerimônia aconteceu em 12 de agosto de 1951 e foi marcada por discursos que enfatizavam a necessidade e a beleza do novo projeto da matriz. Em seu discurso, Olindo de Lucca, representante da Assembleia Legislativa Municipal, destacou que, após inúmeros entraves e bloqueios criados por pessoas que não queriam que Limeira se desenvolvesse, "surgiu a planta bucólica de majestática beleza campestre da lavra do renomado engenheiro Mario Penteado, que após ser construída seria um dos mais belos e delicados templos do Brasil" (TOMBO V. NSD. p.77v).

Já Raul da Rocha Medeiros Júnior, presidente da Comissão de Obras, elucubrou sobre o 
significado de se construir a igreja de uma cidade, cujo "ato seria uma oração prolongada, o testemunho de uma cidade ao seu Deus". Medeiros apontou ainda que a derrubada da antiga igreja era um ato de respeito para com a cidade, cujo desejo "era de construir uma um templo condigno e isento dos defeitos insanáveis que o outro apresentava". Finalizando o discurso, Medeiros reitera a plena confiança da comissão nos trabalhos do arquiteto Mario Penteado, elogiado pelo orador como profissional "cuja capacidade técnica há muito se impôs ao reconhecimento público, e de quem, neste convívio de dois anos, podemos testemunhar o cuidado, a meticulosidade, a prudência e o esmerado capricho" (TOMBO V. NSD. p.81).

O novo projeto proposto por Penteado apresentava uma igreja muito maior que a antiga matriz. Além do templo, o conjunto possuía um centro pastoral no subsolo e um complexo administrativo na parte posterior. As características arquitetônicas do novo edifício, com sua planta composta por um grande vão na nave central e duas naves laterais separadas por uma arcada, suas aberturas em arcos mistilíneos e janelas quadrilobadas, seus entalhes e ornamentos, e todo o revestimento na roda baixa em azulejos revelam o cuidado e o estudo do arquiteto no tratamento estilístico, que se enquadra no estilo missões, já que predominam os estilemas hispano-americanos (ATIQUE, 2010, p.266). A nova matriz começou a ser construída no ano de 1952, após a total demolição do antigo edifício do século XIX.

Enquanto a construção ainda estava na fase das fundações, os jornais veiculavam informações sobre o novo projeto. Em matéria do dia 28 de agosto de 1952, o "Jornal Limeirense" publicou que a "nova Matriz de Limeira será construída obedecendo ao puro estilo neo-colonial". E buscando valorizar a nova matriz, declara que "só existe, ou melhor, só existirá uma Igreja igual no Brasil - a de São João da Boa Vista ${ }^{16 " ~(T O M B O ~ V I . ~ N S D . ~ p .21)-~ o ~ q u e ~ s e ~ t r a t a ~ d e ~ u m a ~}$ inverdade, pois já existiam inúmeros exemplares de igrejas neocoloniais construídas pelo país, inclusive em cidades próximas a Limeira, como mostrado neste estudo.

Figura 72: Demolição total da antiga Matriz de Limeira, com destaque para a capela do santíssimo, recém-concluída, com o quadro de São Tarcísio. Fonte: Acervo da Catedral Nossa Senhora das Dores.

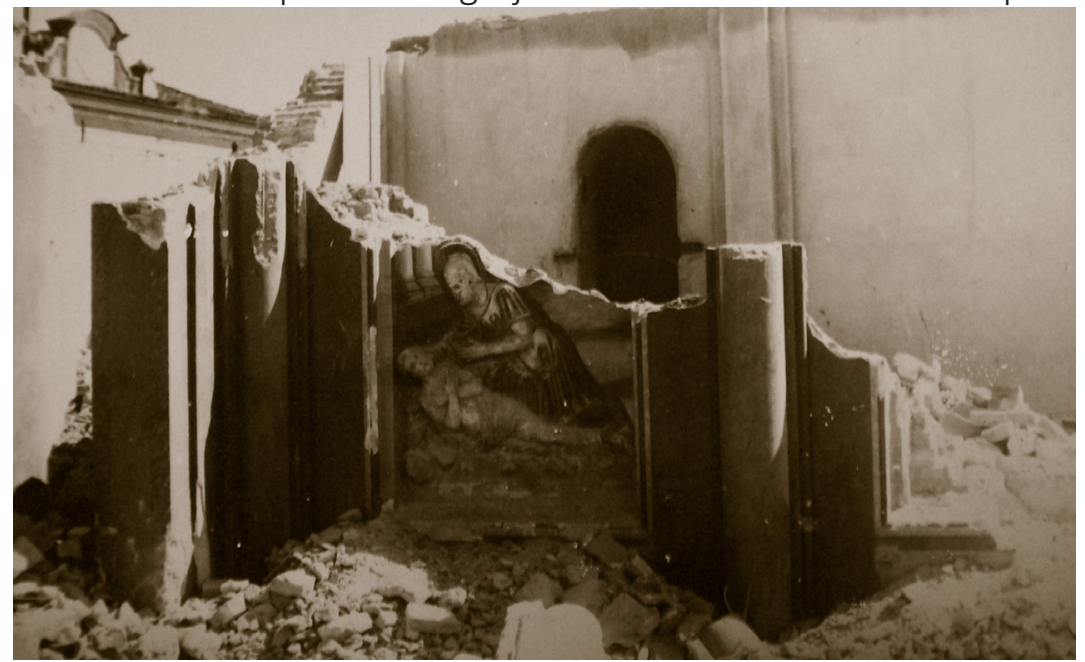

16 Trata-se da igreja neocolonial de Nossa Senhora do Perpétuo Socorro projetada pelo Arquiteto Benedito Calixto Neto (LIVRO TOMBO VI. NSD. p.21.). 


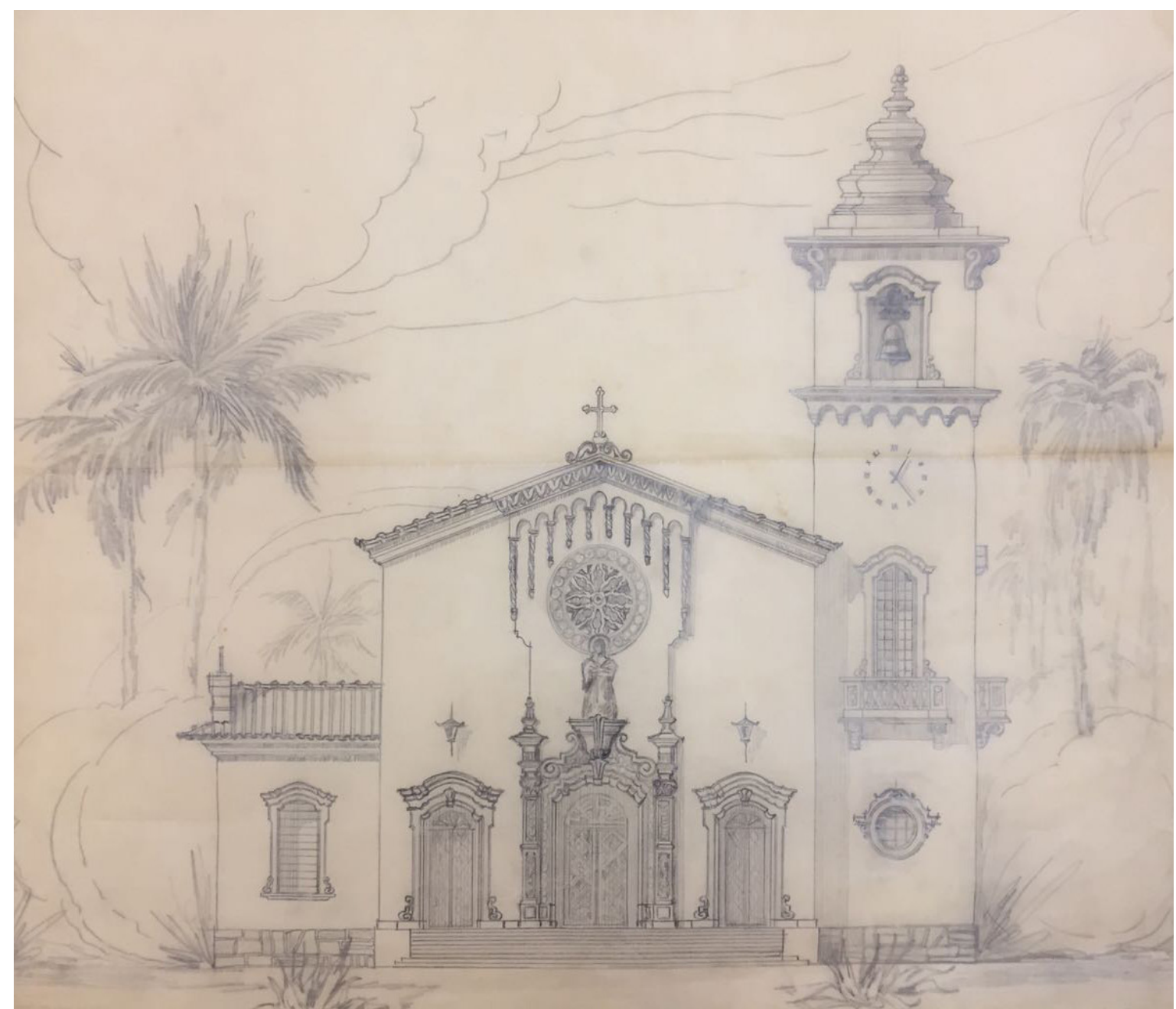

Figura 73: Primeiro estudo em neocolonial para a Matriz de Limeira. Penteado ainda não havia proposto as naves laterais e o complexo administrativo na parte posterior do tempo, alterações que deixaram a igreja muito maior do que neste primeiro estudo. Fonte: Centro de Apoio Acadêmico da PUC Campinas. 


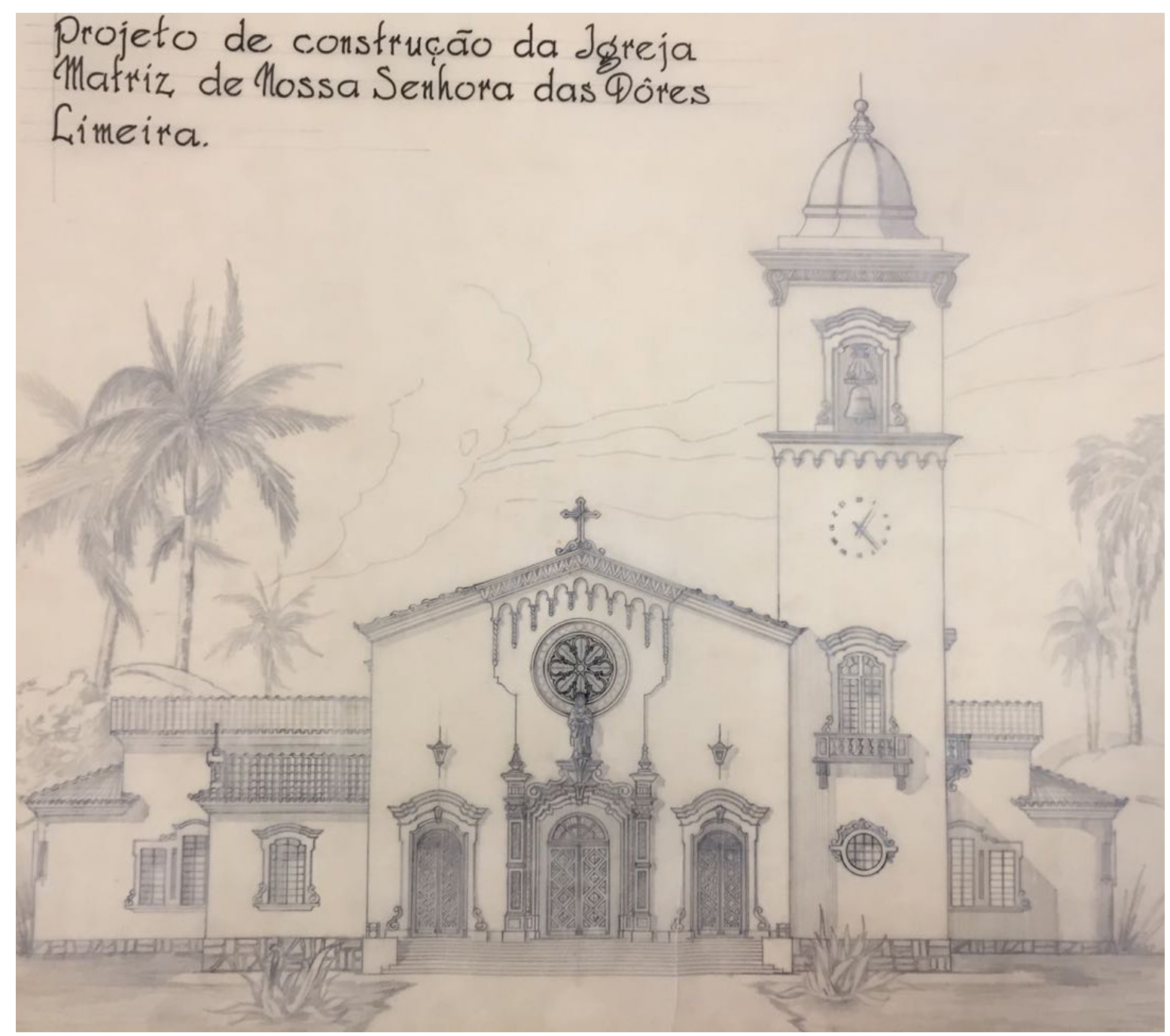

Figura 74: Elevação principal do projeto final de Mario Penteado em estilo neocolonial para a Matriz de Limeira. Nota-se as diferenças com o primeiro estudo, principalmente na altura da torre e no formato da cupúla. Fonte: Centro de Apoio Acadêmico da PUC Campinas.

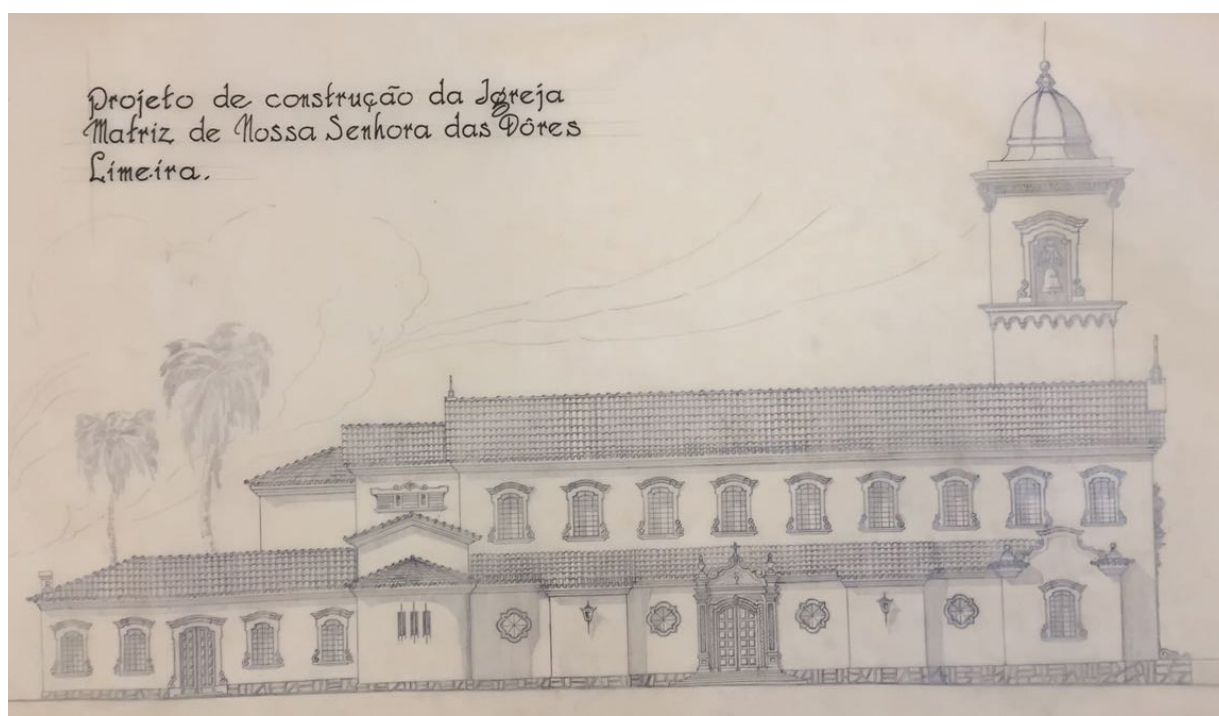

Figura 75: Elevação lateral do terceiro projeto de Mario Penteado, em estilo neocolonial, para a Matriz de Limeira, realizado em 1925. Fonte: Centro de Apoio Acadêmico da PUC Campinas. 


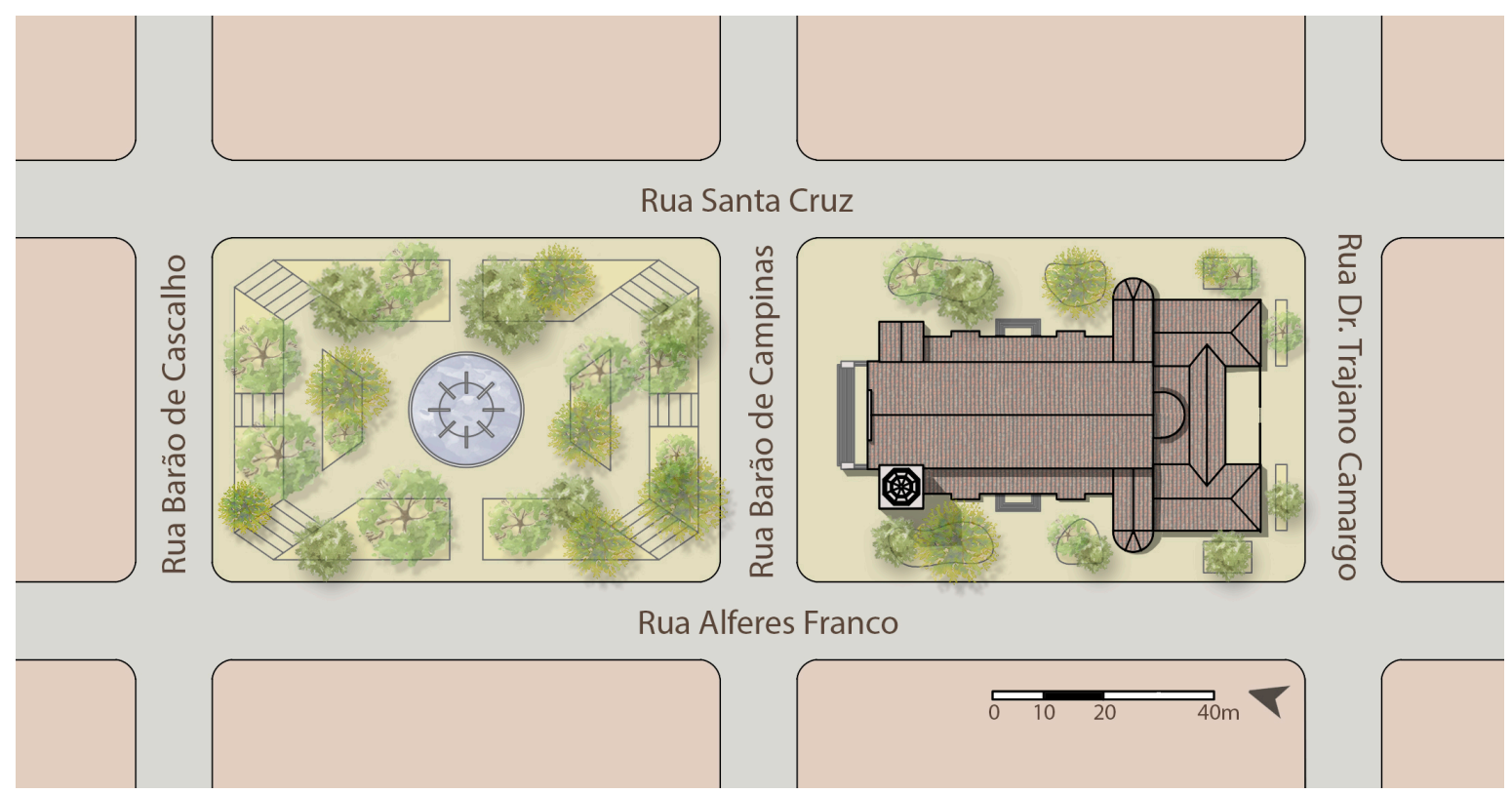

Figura 76: Implantação da Igreja Nossa Senhora das Dores na Praça Luciano Esteves, no centro de Limeira . Desenho: Renan Treft.

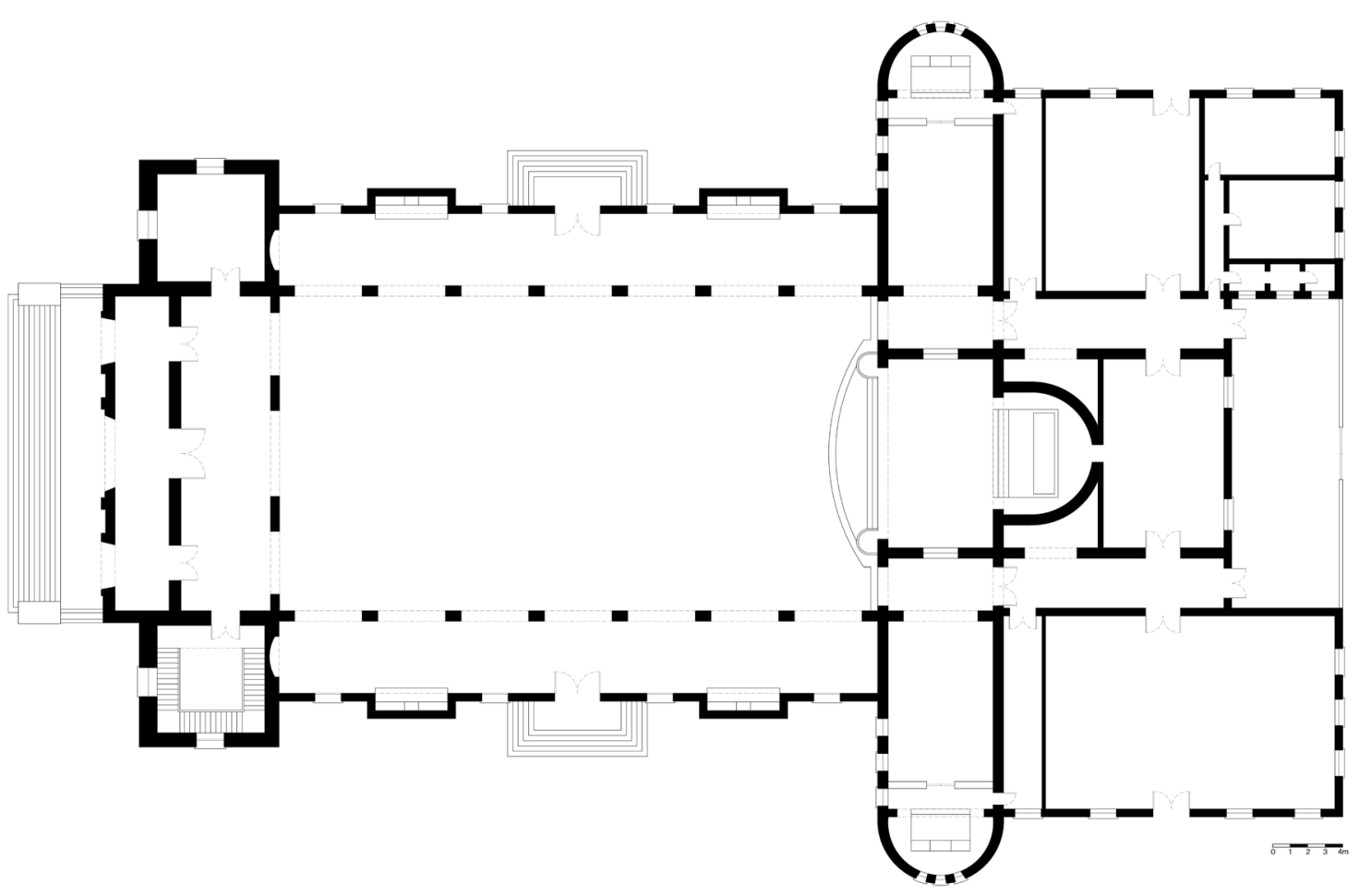

Figura 77: Planta do projeto neocolonial da Igreja Matriz de Limeira. A disposição dos espaços revela uma maior complexidade, tanto no espaço litúrgico, quanto no espaço administrativo-pastoral, criado em seu anexo.

Fonte: Baseado no original do Centro de Apoio Didático da PUC Campinas. Desenho: Renan Treft.

O andamento das obras da Matriz não aconteceu como planejado. Atrasos ocasionados por diversos fatores fizeram com que a obra fosse se arrastando ao longo dos anos, e não fosse concluída no prazo previsto. O tamanho da igreja dificultou sua construção, cujos custos 
se tornaram cada vez maiores. Para acalmar a população - que cobrava a entrega da nova Matriz- e fazê-la tomar ciência do progresso da empreitada, foi lançado em agosto de 1951 um programa de rádio que ia ao ar diariamente às 17:00 horas (TOMBO VI. NSD. p. 89), com boletins e informações sobre o andamento das obras e as próximas etapas de trabalho a serem realizadas.

O relatório da visita pastoral de 1956 informa que as obras iam bem e que logo a igreja estaria coberta, e assim, "Limeira poderá oferecer a sua padroeira, um dos mais notáveis monumentos de arte religiosa do Estado de São Paulo" (TOMBO VI. NSD. p.85v). Em 15 de setembro de 1959, foi celebrada a primeira missa na igreja ainda inacabada, que era considerada como sendo a "mais perfeita obra da engenharia moderna" (TOMBO VI. NSD. p.96v). A celebração do dia da padroeira aconteceu após a finalização da parte estrutural do edifício, mas com a igreja ainda inacabada, para que todos pudessem visitar e conhecer o andamento das obras, e, assim, colaborar na campanha em prol da sua finalização.

No entanto, devido às dificuldades enfrentadas naquele momento, a Igreja Matriz foi inaugurada em 1970 sem os acabamentos externos. Os demais ornamentos foram colocados na igreja apenas no ano de 1990, porém nem tudo foi executado conforme o projeto original. Devido às alterações propostas pelo Concilio Ecumênico Vaticano II mudanças foram realizadas no espaço litúrgico, a saber: o altar foi deslocado para o centro da capelamor, a grade de comunhão foi eliminada, e os altares laterais não foram executados. $\mathrm{Na}$ fachada principal, os dois grandes lampiões e a imagem de Nossa Senhora das Dores não foram colocados. Nas portadas é possível identificar a ausência de elementos decorativos, principalmente nas laterais.

Figura 78: Igreja Matriz em 1970. Fonte: Acervo da Catedral Nossa Senhora das Dores.

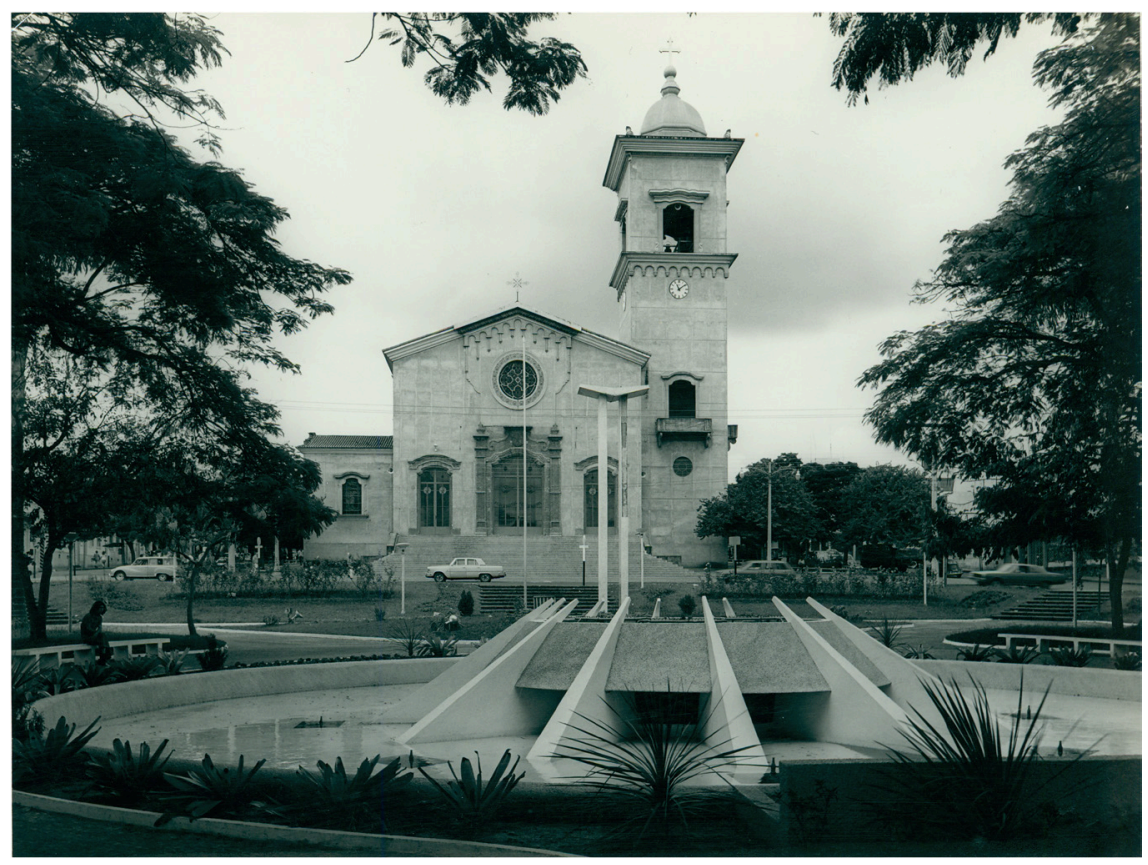


A atual Catedral recebeu ainda inúmeras intervenções contemporâneas, como o fechamento das envasaduras do campanário, novas pinturas decorativas e uma grande reforma no presbitério, além da construção de jazigos na Capela São José (2005-2006). Tais reformas foram realizadas sob justificativa de adequação do templo aos elementos característicos de uma Igreja Catedral. Em 2017 foram realizadas novas intervenções no interior e no exterior do edifício, completando-se partes não finalizadas do projeto e criando novos elementos e decorações. Contudo, tais reformas, que aconteceram com o passar dos anos, desfiguraram em parte o projeto original e o estilo arquitetônico.

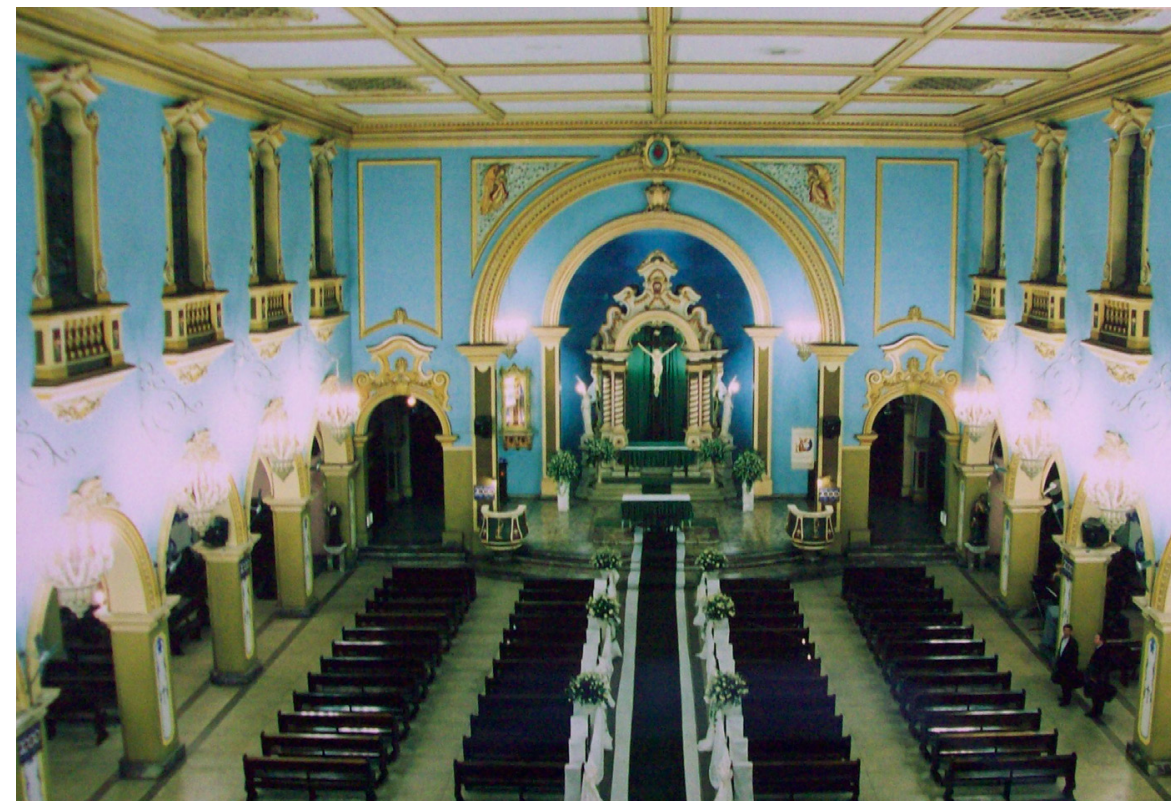

Figura 79: Igreja Matriz internamente em 1990.Fonte: Acervo da Catedral Nossa Senhora

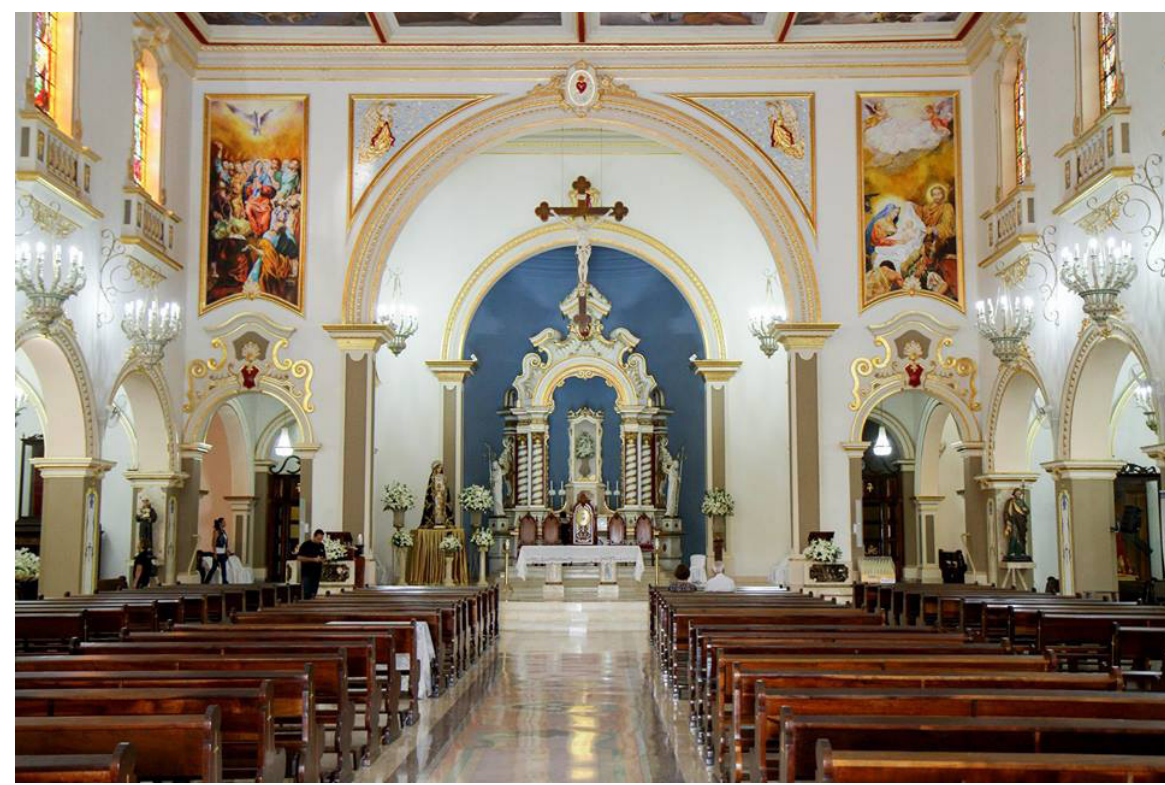
das Dores

Figura 80: Interior da Catedral Nossa Senhora das Dores em 2018. Fonte: Acervo do autor. 


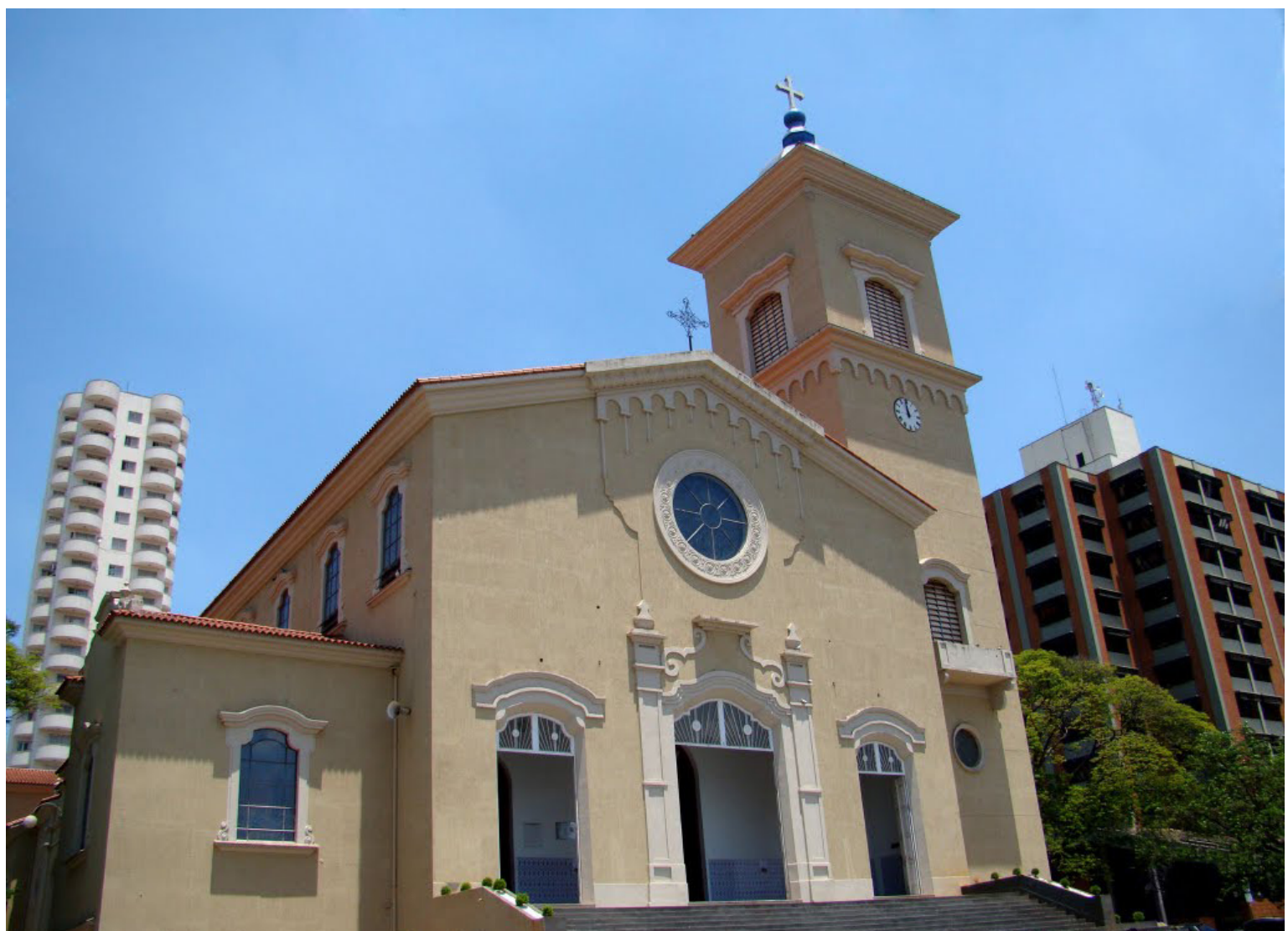

Figura 81: Catedral Nossa Senhora das Dores em 2018. Fonte: Diocese de Limeira.

\section{UM NOVO ÂNIMO PARA SANTA CRUZ DA CONCEIÇÃO - A REFORMA DA IGREJA MATRIZ}

A intermitência de párocos na Paróquia de Santa Cruz da Conceição preocupava a cúpula Diocesana. Como apontado no capítulo 02 (p.100), a paróquia passou longos períodos sem um administrador exclusivamente dedicado às suas necessidades, o que acabou gerando uma instituição instável e repleta de dificuldades. A ausência de autonomia administrativa e sua anexação à paróquia de Leme dificultaram o progresso da Paróquia Nossa Senhora da Conceição de Santa Cruz da Conceição.

Além das questões pastorais e espirituais da paróquia, o atendimento não contínuo do serviço religioso reverberou também no edifício da Igreja Matriz. Os serviços ordinários de manutenção não eram executados, pois não havia quem empreendesse campanhas junto à população e nem mesmo os encomendasse, quando necessário. O problema se tornava ainda pior pela ausência de recursos financeiros, que tornavam a vida da pequena paróquia quase inviável, pois, como já apontado, nem mesmo os pedidos feitos pelo bispo diocesano eram realizados.

Em 1938, o Pe. Manoel Lima, que era o pároco de Leme, assume também os trabalhos da paróquia de Santa Cruz da Conceição, e procura começar um trabalho de reestruturação 
da comunidade. Os desafios que se apresentavam eram variados, porém, o reverendo deu prioridade à consolidação das atividades religiosas, fazendo com que a paróquia voltasse a ser prestigiada e pudesse atuar como um importante agente na sociedade. Assim, os problemas de manutenção da matriz ficaram em segundo plano, e só foram enfrentados 10 anos depois:

Em vista do mau estado em que se acha a Matriz, e já contando com algumas economias, foi organizada uma comissão para reforma-la. Foi organizada uma comissão [...] a demolição do telhado e madeiramento foi iniciada em 5 de maior de 1947. Desaparecerão as tribunas de madeira por serem inúteis. Só ficará a tribuna dos cantores. Serão abertas amplas janelas nas paredes laterais. $O$ telhado será levantado, tudo obedecerá ao estilo colonial, de acordo com o altar mor que é desse estilo (TOMBO III. NSC. p.47). [grifo nosso]

De autoria desconhecida, o projeto de reforma para a igreja de Santa Cruz da Conceição apresentava mudanças na fachada, com a inserção de aberturas do tipo boca de carpa, próprias do Neocolonial, porém não realizava alterações na planta do edifício, que continuava com a mesma área, embora tivesse seu pé direito aumentado. A torre central existente recebeu uma cúpula bulbosa e uma nova ornamentação.

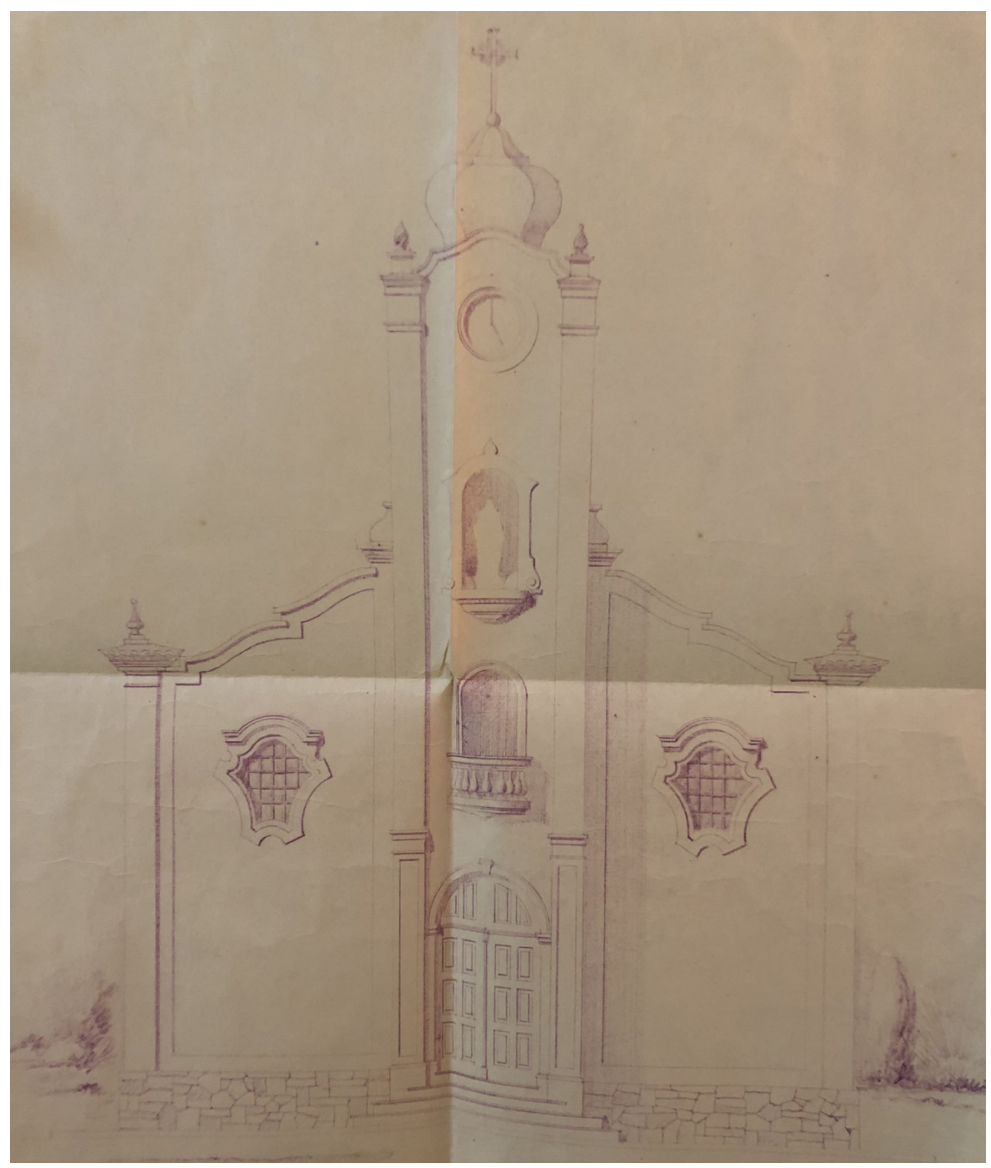

Figura 82: Projeto da reforma da fachada da Paróquia Nossa Senhora da Conceição. Fonte: Acervo da Paróquia Nossa Senhora da Conceição. 


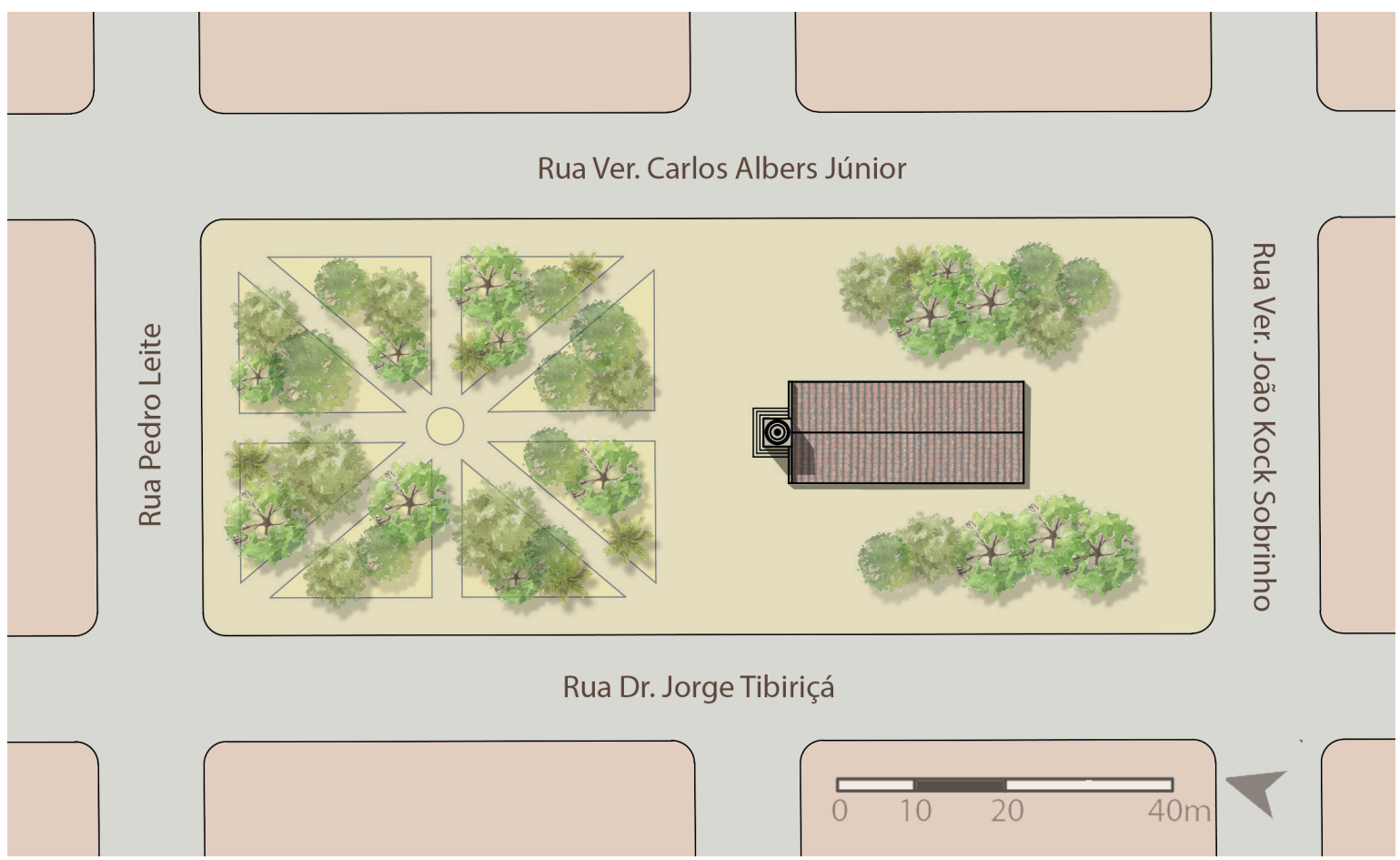

Figura 83: Implantação da Igreja Nossa Senhora da Conceição na Praça Nicanor Sampaio Albers. Nota-se o tamanho da igreja na praça e sua planta retangular. Desenho: Renan Treft.

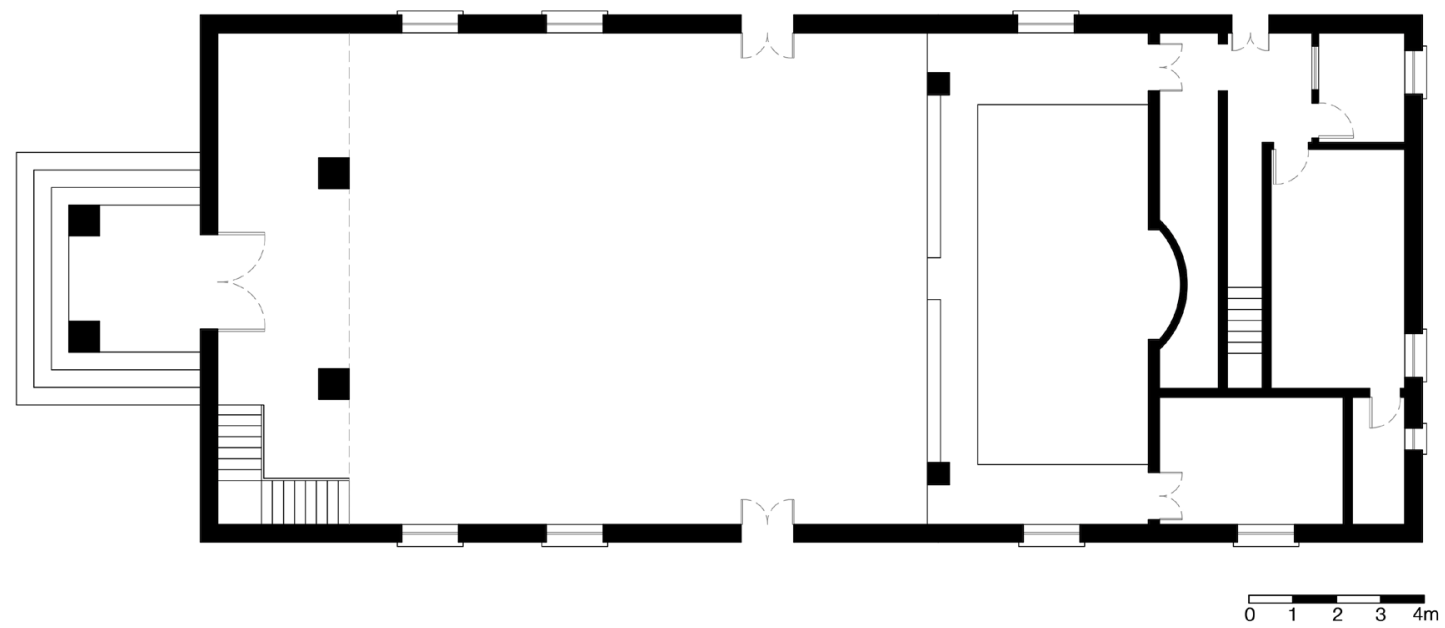

Figura 84: Planta da Igreja Nossa Senhora da Conceição após a reforma. Fonte: Paróquia Nossa Senhora da Conceição Desenho: Renan Treft.

Em 1948, um ano após o início das obras, as atividades religiosas voltaram a acontecer na Igreja Matriz devido à nomeação de um novo pároco para Santa Cruz da Conceição; no entanto, a igreja estava inacabada. Já haviam sido feitos todos os trabalhos estruturais e de remoção do que seria suprimido, mas estavam faltando os trabalhos de acabamento, o novo forro e a colocação dos caixilhos nas novas janelas, serviços estes que foram sendo realizados paulatinamente. 
A vinda do novo pároco acarretou o abandono das obras de finalização da igreja, diante da necessidade de reformar a casa paroquial. A casa, que estava sem uso até então, estava abandonada, e servindo para a criação de bicho da seda, segundo registros do próprio padre (TOMBO III. NSC. p. 53v). O novo pároco se assustou ao se deparar com a situação da paróquia:

O pequeno número de fiéis, que está espalhado por um território relativamente grande, torna o serviço da paróquia difícil. O povo da Vila não sente a necessidade de um sacerdote, habituados naquela indiferença dos anos passados, todos continuam no mesmo ritmo. De semana quase não vem ninguém a missa [...] a participação varia muito, tem dia que não aparece ninguém (TOMBO III. NSC. p.54).

E sobre a Igreja Matriz completou:

Já faz três anos que a matriz está em reforma. Na minha chegada encontrei a Igreja em tal estado, que foi impossível celebrar a Santa Missa nesse templo, por esse motivo, celebro o Santo Sacrifício na Capela São Benedito (TOMBO III. NSC. p.54).

Apesar do empenho dos padres nomeados para o cuidado da paróquia de Santa Cruz da Conceição, os problemas que lá ocorriam eram recorrentes, e sempre atrapalhavam a vida da comunidade. Em 1950, o novo pároco tenta retomar as obras para finalizar a Igreja Matriz, porém, problemas com a comissão nomeada anteriormente dificultaram ainda mais os serviços. Somente em 11 de dezembro de 1954 a reforma da Igreja Matriz de Nossa Senhora da Conceição foi finalizada, e suas novas estruturas solenemente abençoadas e inauguradas. Na ocasião, o bispo diocesano destacou a qualidade do templo e a devoção do povo santa-cruzense que "doaram a Nossa Senhora da Conceição o magnífico templo" (TOMBO III. NSC. p.67).

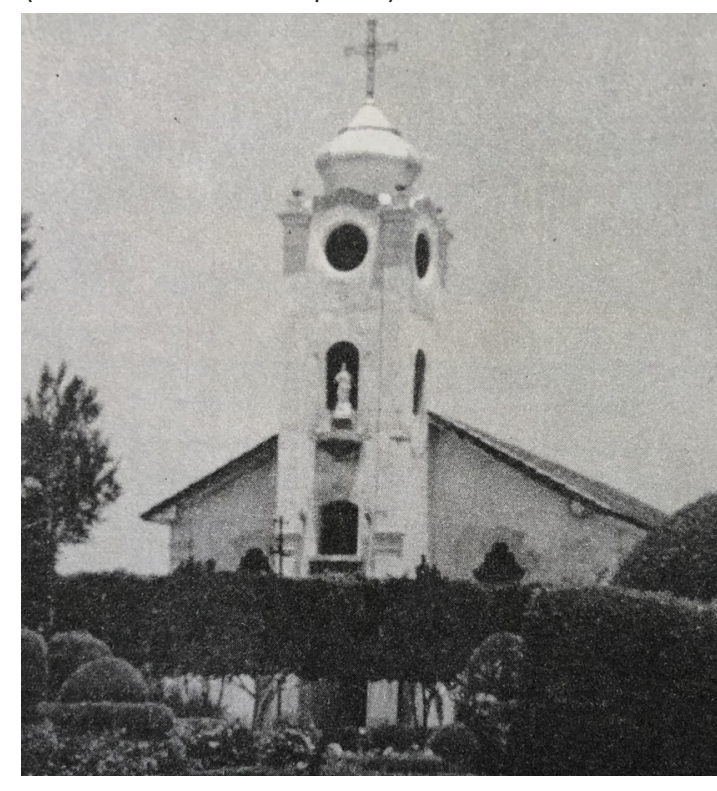

Figura 85 : Igreja Matriz de Santa Cruz da Conceição na década de 60 ainda inacabada. Nota-se que apenas a torre estava concluída, faltando acabamentos de arremate nos telhados e nos beirais. Fonte: Acervo da Paróquia Nossa Senhora da Conceição. 


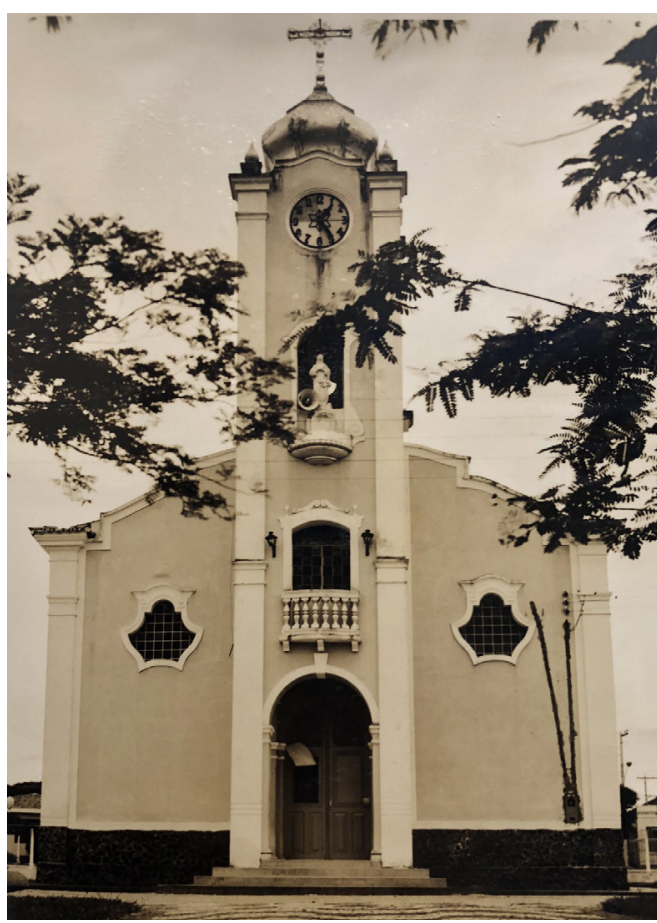

Figura 86: Igreja Matriz Nossa Senhora da Conceição em 1975. Fonte: Acervo da Cúria Metropolitana de Campinas.

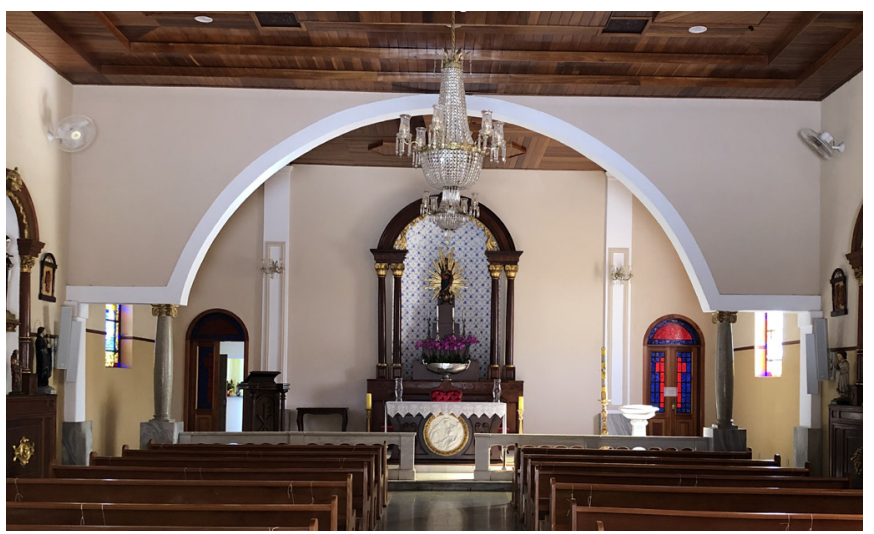

Figura 87: Interior da Igreja Nossa Senhora da Conceição em 2020. Fonte: Acervo do autor.

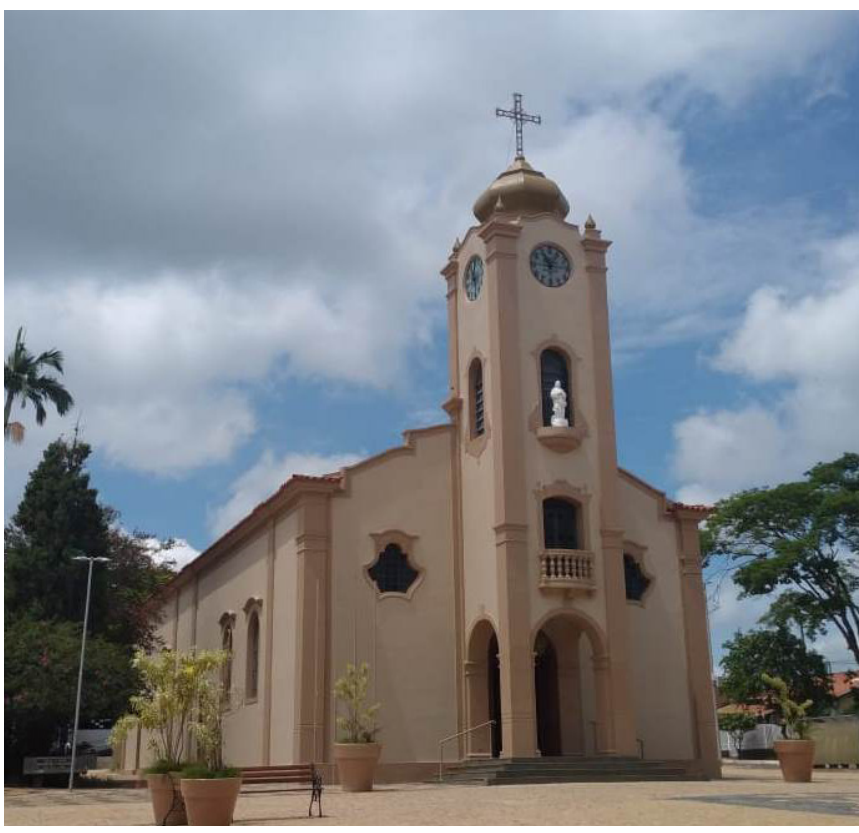

Figura 88: Igreja Matriz Nossa Senhora da Conceição em 2020. Fonte: Diocese de Limeira. 


\section{UMA NOVA MATRIZ PARA PORTO FERREIRA}

A cidade de Porto Ferreira se manteve estável e não apresentou crescimento populacional significativo durante várias décadas; assim, sua Matriz - que tinha sido reformada em 1904 (Cap. 1, p.103)- continuava condizente com a sua realidade e suas necessidades paroquiais. No entanto, em meados de década de 40, a cidade passou um período de efervescência econômica e de renovação social. Dentre os fatos que contribuíram para tal, pode-se indicar a chegada de novas industrias do ramo cerâmico, a criação de novos loteamentos e a construção da rodovia Anhanguera (SP-330), cujo trajeto foi alterado para uma região próxima à cidade de Porto Ferreira. As terras compreendidas entre a rodovia e o antigo centro urbano, que eram de propriedade do vice-governador na época, Dr. Erlindo Salzano, foram loteadas e receberam o nome de cidade nova (ARNONI, 2015).

No que se refere à Igreja Matriz, a ausência de documentos não esclarece os motivos que levaram o pároco a querer construir uma nova igreja. As primeiras manifestações em favor da demolição da antiga igreja, ainda que sem uma justificativa concreta, constam nos relatórios da visita pastoral de 1942 (BARRETO, 1942, p.02).

O crescimento populacional pelo qual vinha passando a cidade, e um montante pecuniário destinado à construção de uma nova matriz, legado em testamento da Sra. Olympia Meirelles Carvalho, cujo falecimento ocorreu em 1936, são fatores apontados como determinantes no processo que culminou na reconstrução do antigo templo (ARNONI, 2015).

Os rumores de que a antiga igreja iria ser demolida motivaram inquietações na sociedade ferreirense. Num primeiro momento, a ideia não foi bem recebida, pois os munícipes encontravam na igreja valores identitários e sentimentais. Além disso, a igreja não apresentava nenhum problema construtivo, e encontrava-se conservada e asseada.

Essas manifestações partiam da população em geral e de pessoas ligadas a grupos sociais e políticos da cidade. O vice-govenador do estado, Erlindo Salzano, publicou uma série de artigos no jornal "O Ferreirense" criticando a hipótese de se substituir a velha matriz. Seus argumentos eram de que a igreja estava em ordem e era um patrimônio histórico da cidade, e que o seu desaparecimento ocasionaria a perda de uma memória coletiva importante para a cidade de Porto Ferreira. No entanto, Salzano era favorável à construção de uma nova matriz, porém, em local distinto do original, pois a antiga estava mal localizada. Com o crescimento da cidade em direção à "cidade nova", o vice-governador viu a oportunidade de migrar a igreja matriz de lugar, movendo assim todo o centro para uma parte nova, topograficamente mais alta - o que, consequentemente, valorizaria as suas terras recém loteadas (ARNONI, 2015). 
No entanto, nenhuma manifestação favorável à salvaguarda da antiga matriz foi profícua. O crescimento da cidade era notável- a população passou de 7.000 habitantes em 1950-, o que tornava a substituição da antiga matriz algo inevitável, e sua mudança para outro sitio, inviável, devido à necessidade de se manter a sede da paróquia no seu lugar de origem.

Os trabalhos pró-construção da nova matriz passaram a movimentar toda a cidade. Em 1950, o projeto já estava pronto e a comissão de obras nomeada para os trabalhos ${ }^{17}$. Em 20 de janeiro de 1952, foi celebrada a missa para a colocação da pedra fundamental da nova matriz, que contou com a presença do bispo diocesano e autoridades civis ${ }^{18}$.

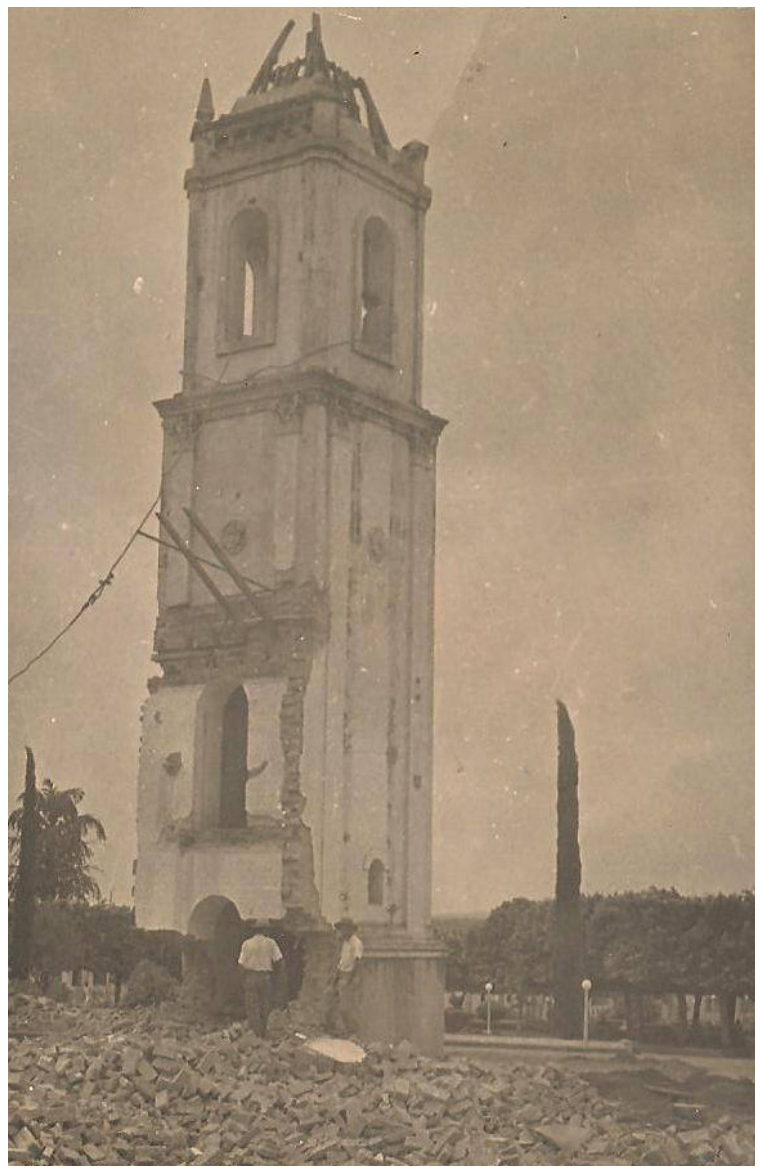

A demolição da antiga matriz iniciou-se nos dias seguintes à colocação da pedra fundamental da nova igreja. Concluídos os trabalhos de remoção do antigo arcabouço, começou a preparação das fundações para a nova construção. Enquanto isso, as atividades da paróquia foram transferidas para as capelas de São Benedito e do Hospital Dona Balbina.

As obras tiveram um grande impulso, e em 1955 a igreja encontrava-se pronta e totalmente coberta, o que viabilizou a sua utilização ainda inacabada (OLIVEIRA, 2005, p.53). Os acabamentos foram sendo colocados paulatinamente, com o decorrer dos anos, conforme o sucesso das campanhas empreendidas para tal fim.

Figura 89: Demolição da antiga matriz de Porto Ferreira. Fonte: Acervo do Museu Histórico e Pedagógico Flávio da Silva Oliveira.

\section{O NEOCOLONIAL DE BENEDITO CALIXTO DE JESUS NETO}

Apesar dos registros referentes à paróquia de São Sebastião serem quase inexistentes, há uma série de documentos guardados pelo arquiteto Benedito Calixto Neto que ilustram o

17 Entre os membros da comissão, estava o engenheiro Nicolau de Vergueiro Forjaz, responsável técnico pelo projeto executivo. Nicolau era filho de Lúcia Vergueiro Forjaz, bisneta do Senador Vergueiro, proprietário do Engenho Ibicaba e fabriqueiro de Limeira.

18 Informações obtidas na Ata de Lançamento da Pedra Fundamental. Santuário São Sebastião, Porto Ferreira, SP. 
processo de concepção do projeto e a construção da nova matriz de Porto Ferreira.

Benedito Calixto Neto teve grande atuação na construção de igrejas pelo Brasil, principalmente no estado de São Paulo. Em uma de suas cartas, Calixto relata que "continuo com a graça de Deus, podendo me dedicar exclusivamente à arte religiosa. Estou terminando o projeto da nova Basílica de Aparecida e tenho em andamento várias igrejas modernas", na qual se incluía a igreja de Porto Ferreira (NETO, 1951).

Sua produção era variada, adotando modelos de todos os estilos e portes. Não há registros se o estilo empregado em determinada igreja era escolhido por ele ou uma encomenda realizada pelo contratante. Porém, como evidenciado em sua carta, todos os projetos eram tidos como modernos, apesar do distanciamento de suas obras em relação aos cânones da arquitetura tida como moderna - isto é, a arquitetura modernista. No caso da matriz de Porto Ferreira, Calixto a classificou como uma arquitetura de "inspiração colonial modernizada" (NETO, 1951).

A igreja, possuía uma planta simples, em formato de cruz com duas capelas e naves laterais para a colocação de confessionários. Na fachada, duas torres coroadas com bulbos revestidos de pastilhas emolduram o frontispício curvilíneo revestido de azulejos, que traz a imagem de São Sebastião em um nicho central. A parte inferior apresenta três janelas e três grandes arcos delimitando o espaço do galilé, linguagem que é própria das igrejas coloniais brasileiras.

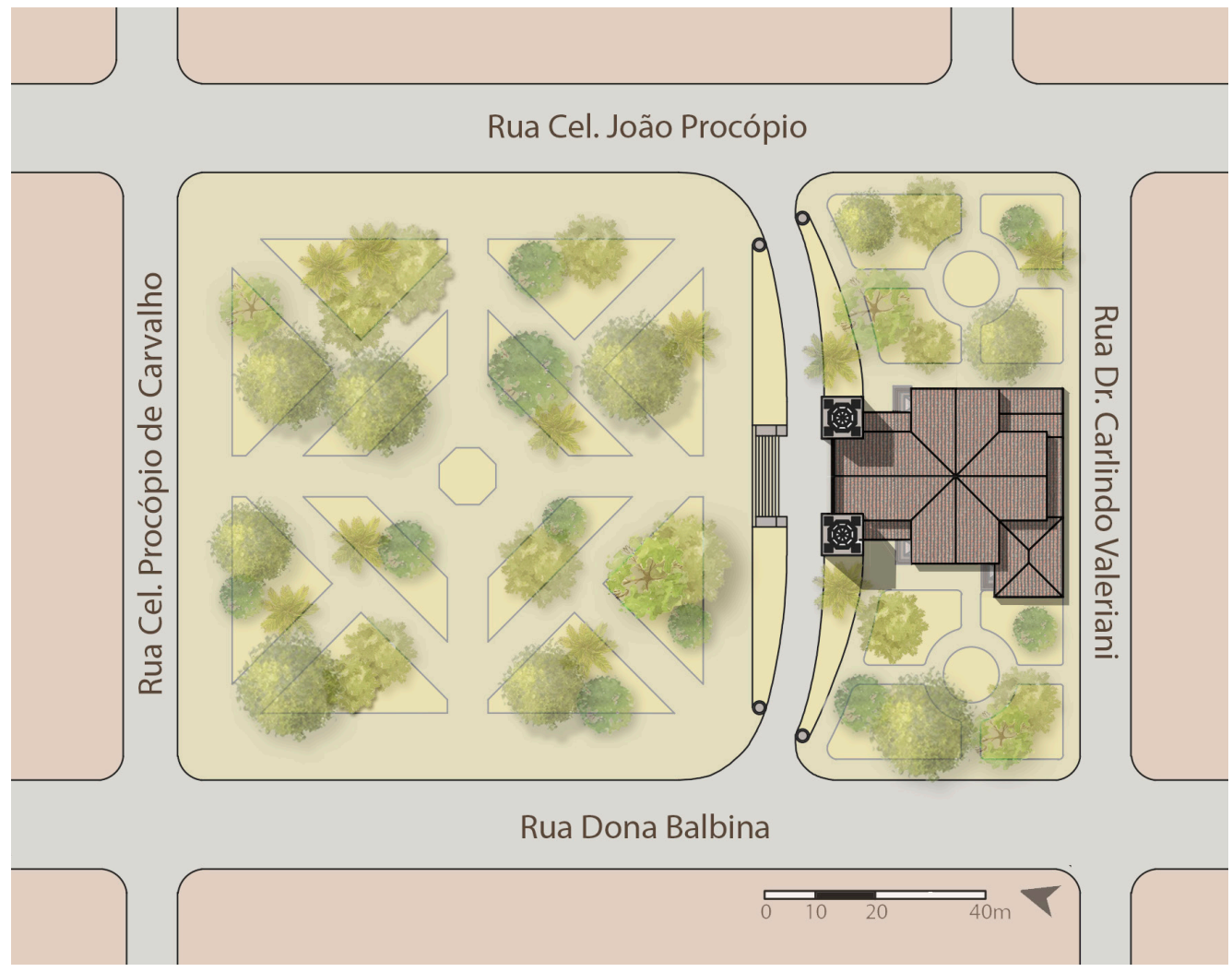

Figura 90: Implantação da Igreja São Sebastião na Praça Cornélio Procópio. Desenho: Renan Treft. 


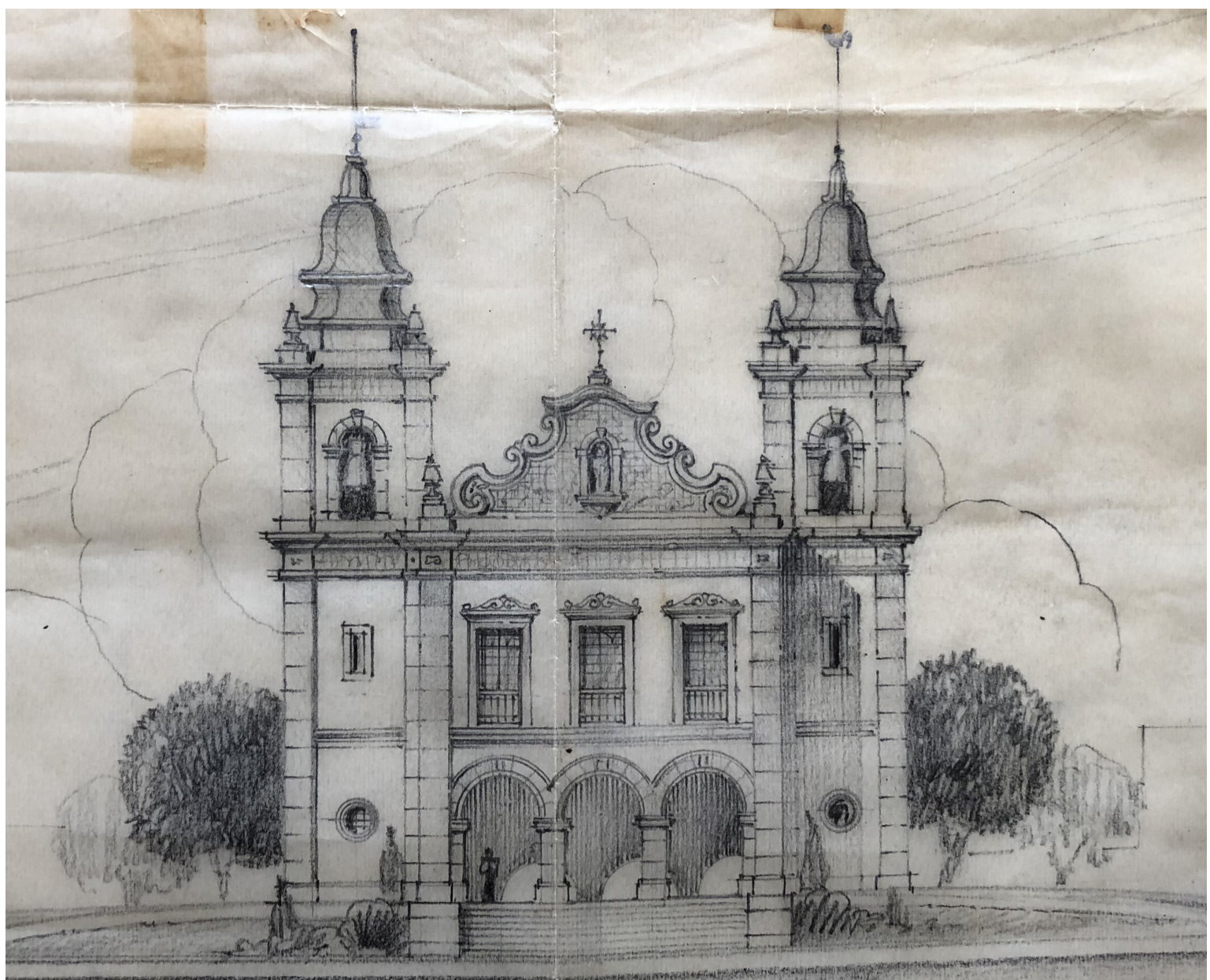

Figura 91: Projeto da fachada da nova matriz de Porto Ferreira. Fonte: Acervo do Santuário São Sebastião.

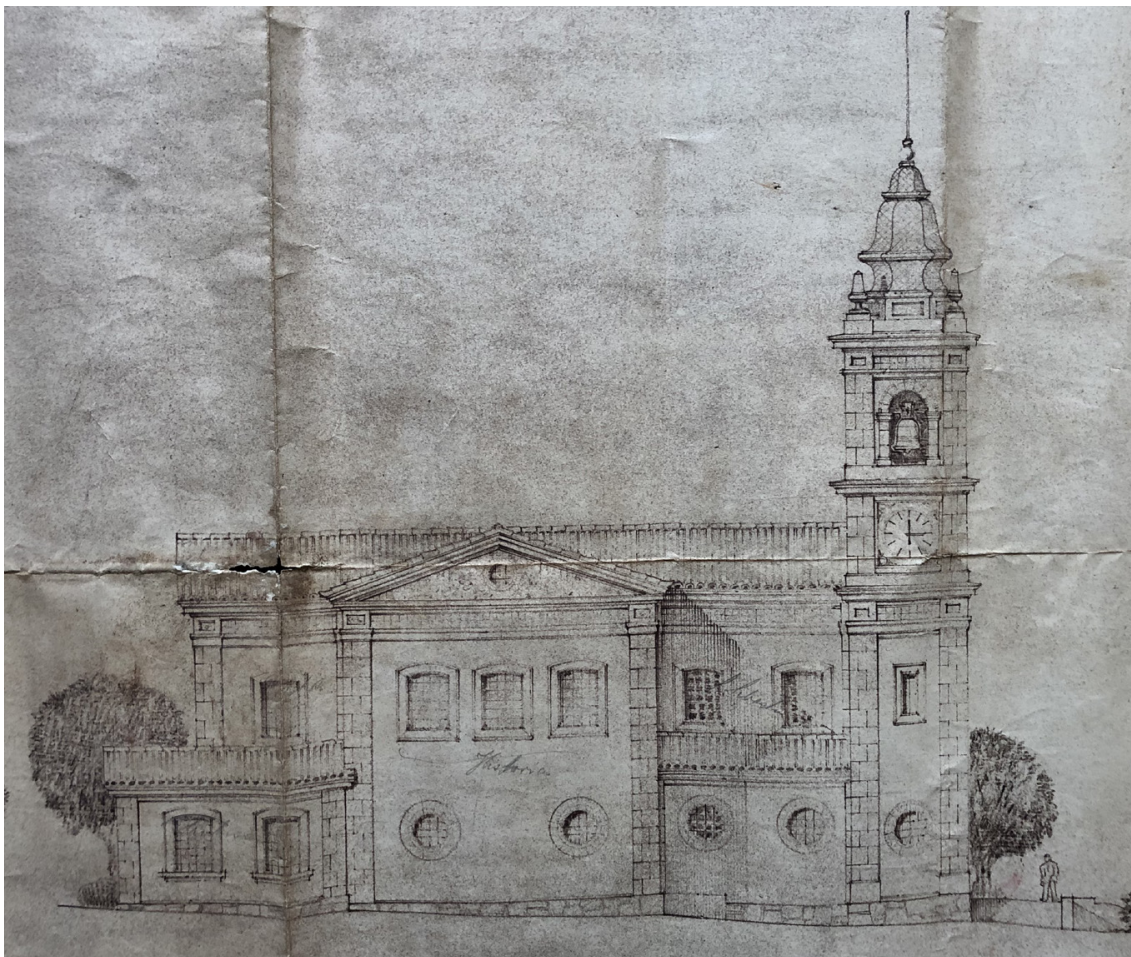

Figura 92: Elevação lateral da Matriz de Porto Ferreira feita por Benedito Calixto Neto. Fonte: Acervo do Santuário São Sebastião. 


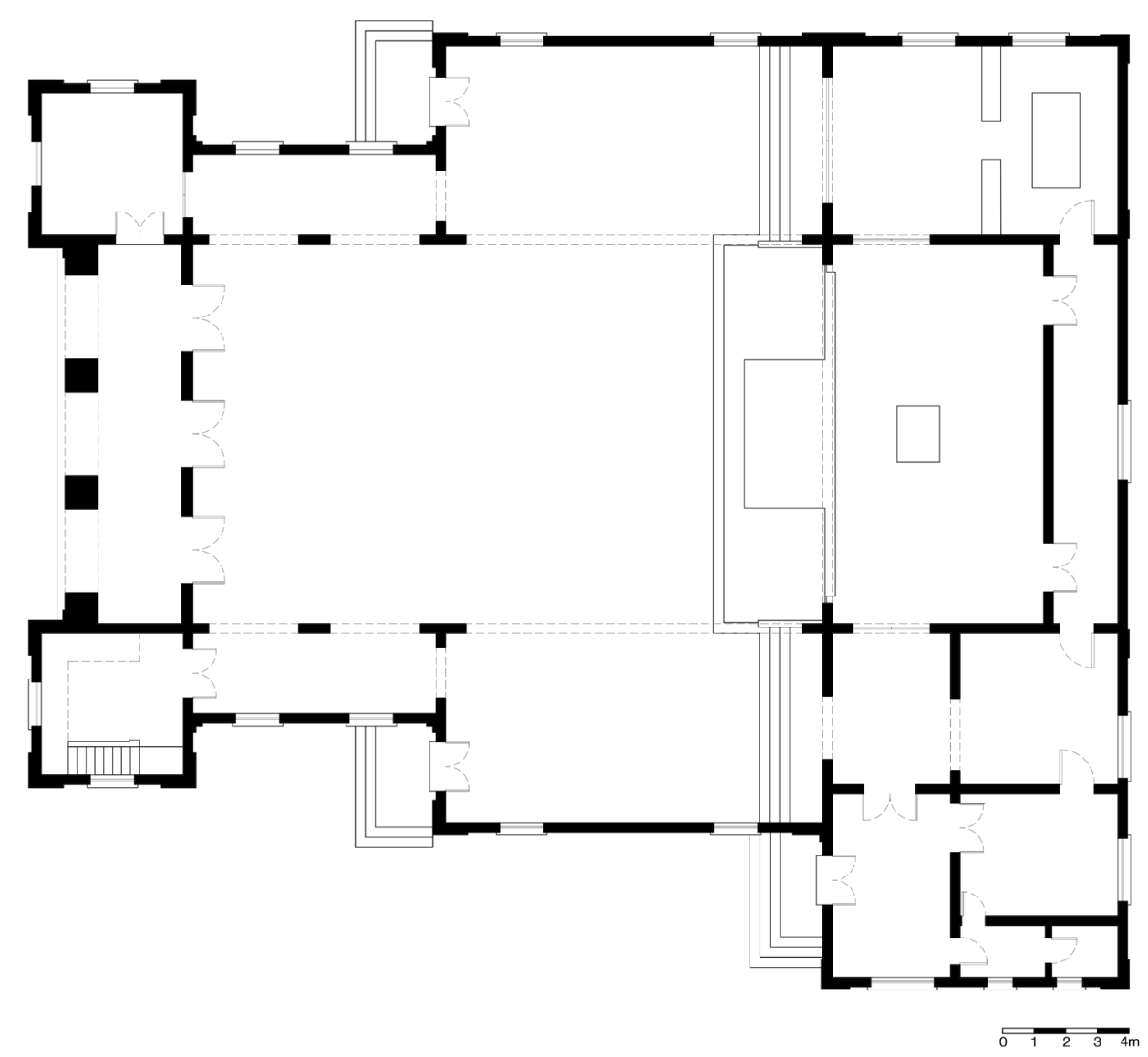

Figura 93: Planta da nova matriz de Porto Ferreira. Fonte: Baseado no original do acervo do Santuário São Sebastião. Desenho: Renan Treft.

O projeto foi encomendado ao arquiteto de forma integral, ou seja, ele era responsável tanto pela arquitetura, quanto pelos acabamentos internos e demais detalhes, como mobiliário, vitrais e utensílios litúrgicos. Em carta ao pároco de Porto Ferreira, Pe. Nestor Cavalcanti Maranhão, o arquiteto enfatiza os benefícios de se manter uma unidade na concepção do projeto.

[...] considerando, no entanto, o interesse de V. Rvma. nos detalhes completos, inclusive mobiliário, etc..., e o meu próprio interesse na exata realização de seu projeto, afim de salvaquardar a unidade de estilo dos detalhes, posso incluir nos honorários de detalhes, as sugestões de desenhos arquitetônicos e desenhar as sugestões para os altares, mobiliários, vitrais, etc. [...] Com referência ao altarmor, poderei projeta-lo já, juntando igualmente, se V. Rvma. assim desejar, um orçamento para sua execução [...] seria favor mandar dizer vossa preferência quanto a forma de altar, número de imagens, enfim, todos estes esclarecimentos que possam me orientar no sentido de satisfaze-lo plenamente (NETO, 1950). [grifo nosso]

Contundo, no percurso de execução da obra, alguns acontecimentos acarretaram mudanças no projeto original. Os altares foram projetados seguido o estilo tradicional de nicho e 
baldaquino, porém, nenhum chegou a ser executado. Os vitrais foram orçados na Casa Conrado de Vitrais, porém, apenas as duas janelas da capela do Santíssimo foram executadas pela empresa. Os demais vitrais foram realizados por Lorenz Heilmair, artista de Porto Alegre e responsável pela execução dos vitrais de várias igrejas no brasil, entre elas, as catedrais de Maringá, Blumenau e do Rio de Janeiro.
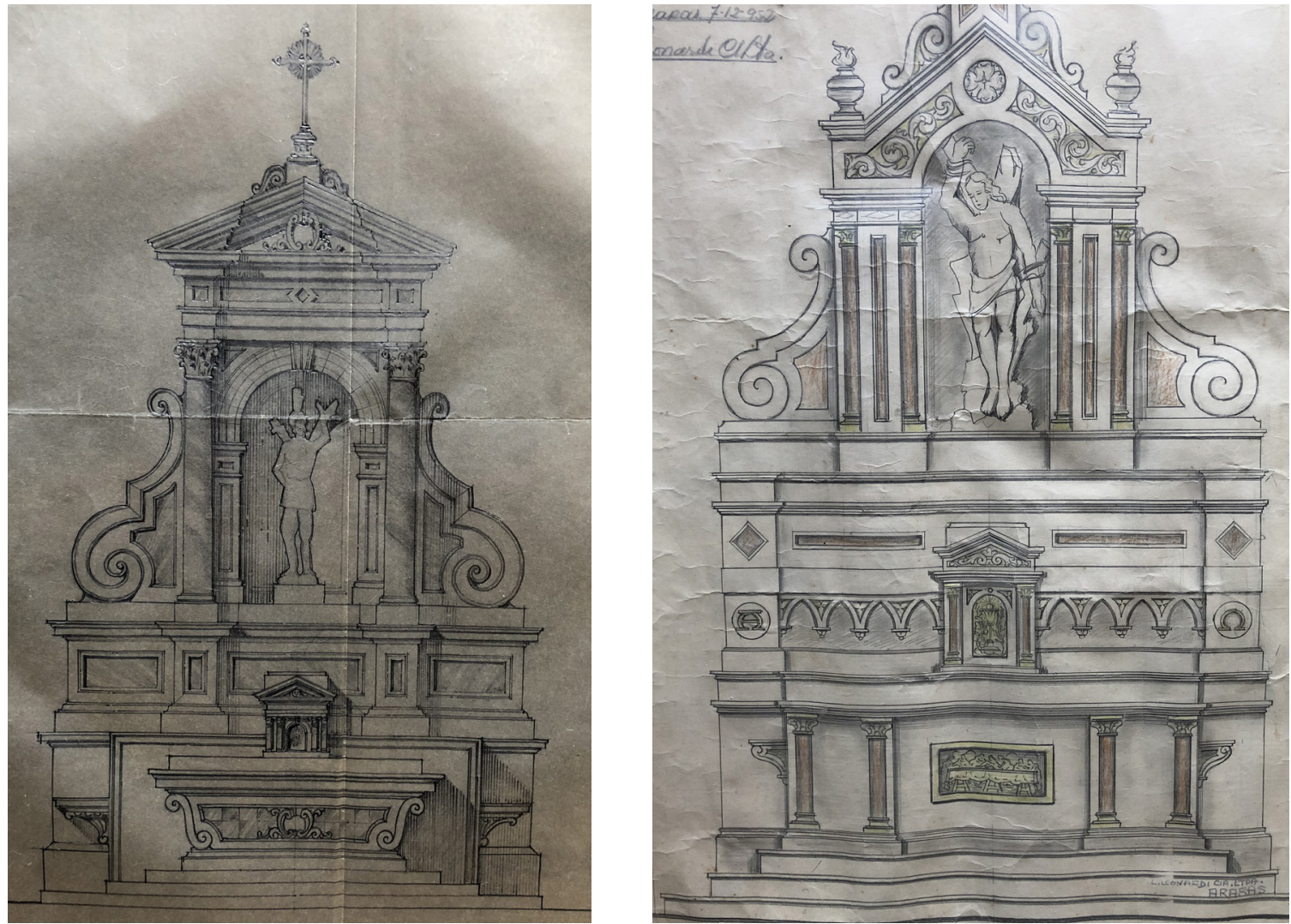

Figura 94 (esquerda): Projeto do altar de São Sebastião realizado por Benedito Calixto Neto. Figura 95 (direita): Projeto de altar para São Sebastião realizado pelo marmorista ararense Luis Leonardi, o mesmo que construiu o altar da primeira igreja de Iracemápolis.Fonte: Acervo do Santuário São Sebastião.

Figura 96: Cruz de altar e castiçal em metal projetados por Benedito Calixto Neto para a Igreja São Sebastião.Fonte: Acervo do Santuário

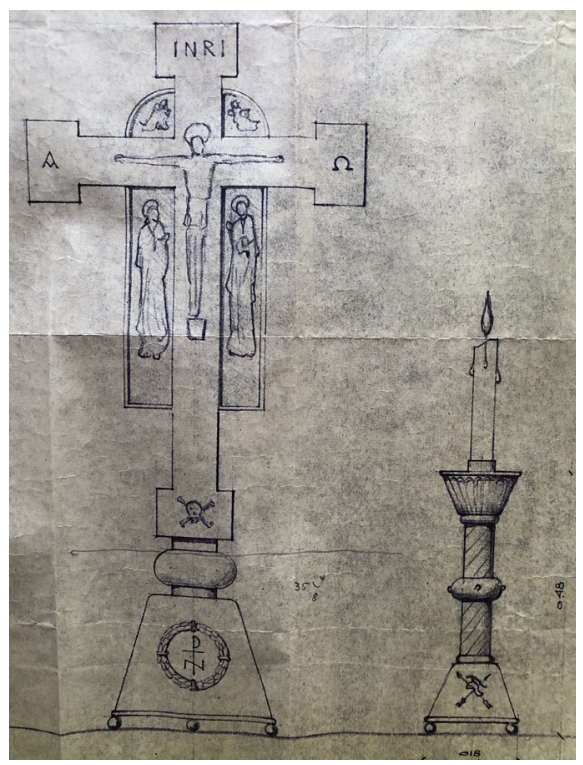

São Sebastião. 
Como estava encarregado pelo acabamento do seu projeto arquitetônico, Calixto foi o responsável por trazer o pintor italiano Antônio Maria Nardi para executar os afrescos do interior da igreja. A primeira aproximação entre os dois ocorreu através de cartas datadas de 1960, quando a igreja já estava quase pronta. Não há registros dos motivos que levaram o arquiteto a optar por realizar um grande painel ao invés de executar os altares em mármore, tal como era praticado na época.

No entanto, é válido destacar que Calixto dedicou sua carreira ao estudo da arquitetura sacra, fazendo viagens regulares ao exterior para se aprofundar no campo. Em meados do século XX, a arquitetura sacra europeia já experimentava novas formas de concepção do espaço sagrado, novos arranjos decorativos e novas formas de arte no auxílio à evangelização. Estes pensamentos e ações podem ser considerados embrionários nas formulações que posteriormente foram consagradas no Concilio Ecumênico Vaticano Il em 1965. Assim, podese dizer que Benedito Calixto Neto estava atento aos acontecimentos e avanços propostos no campo da arquitetura sacra, atuando como um vanguardista na concepção de seus projetos. Ainda que o arquiteto tenha utilizado estilos tidos como tradicionais na concepção de seus trabalhos, o esforço de inserção de elementos estranhos à tradição o prefigura como tal.

Em suas correspondências com Nardi, Calixto aponta que pensava para a Igreja de Porto Ferreira "pinturas entre o acadêmico e o moderno" (NETO,1962), sendo uma pintura com o Sagrado Coração de Jesus, Santa Gertrudes e Santa Margarida Maria Alacoque para a capela do Santíssimo e um grande painel com motivos da vida de São Sebastião para o altar central.

Os croquis foram enviados por Nardi para Calixto para sua avaliação; após aprovados, começaram a ser executados em tamanho original. No painel central, a colocação de um nicho em granito preto tijuca para a imagem de São Sebastião incomodou ao artista, que manifestou achar que tal pedra causaria "uma mancha forte no meio da pintura" (NARDI,

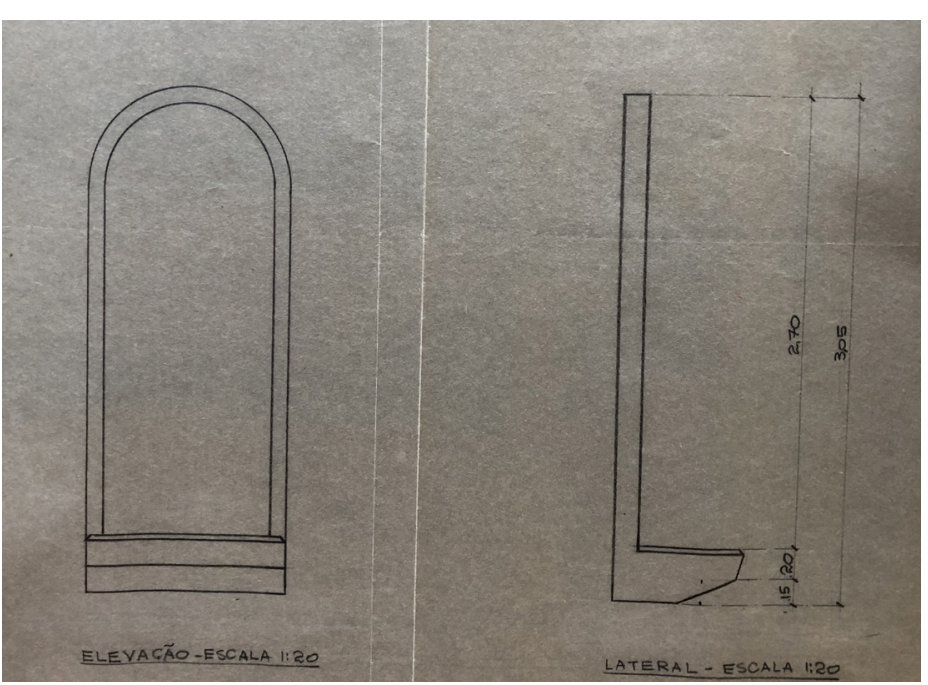
1962). Contudo, nada foi mudado neste aspecto, e em 1963 as pinturas encontravam-se prontas.

Figura 97: Projeto do nicho para a colocação de São Sebastião na parede central do presbitério. Solução simplificada e minimalista perto dos antigos e rebuscados altares de mármore que eram propostos. Fonte: Acervo do Santuário São Sebastião. 


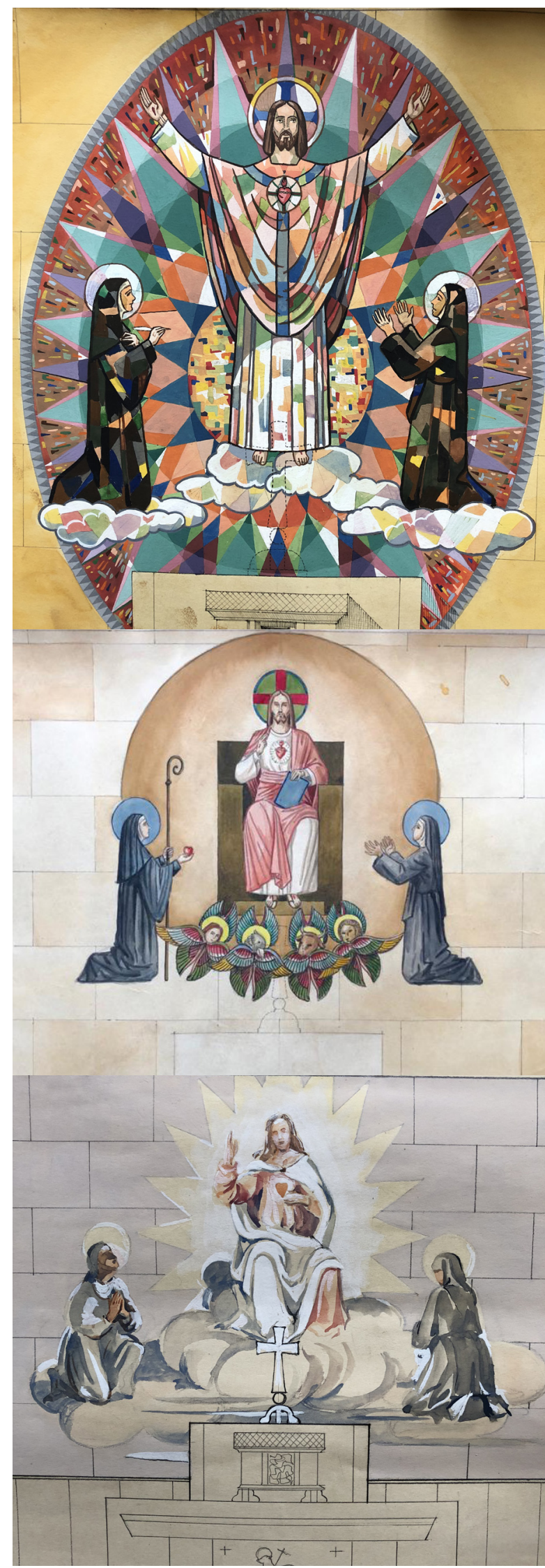

Figura 98: Croquis de estudo da composição decorativa da capela do Santíssimo. Fonte: Acervo do Santuário São Sebastião. 


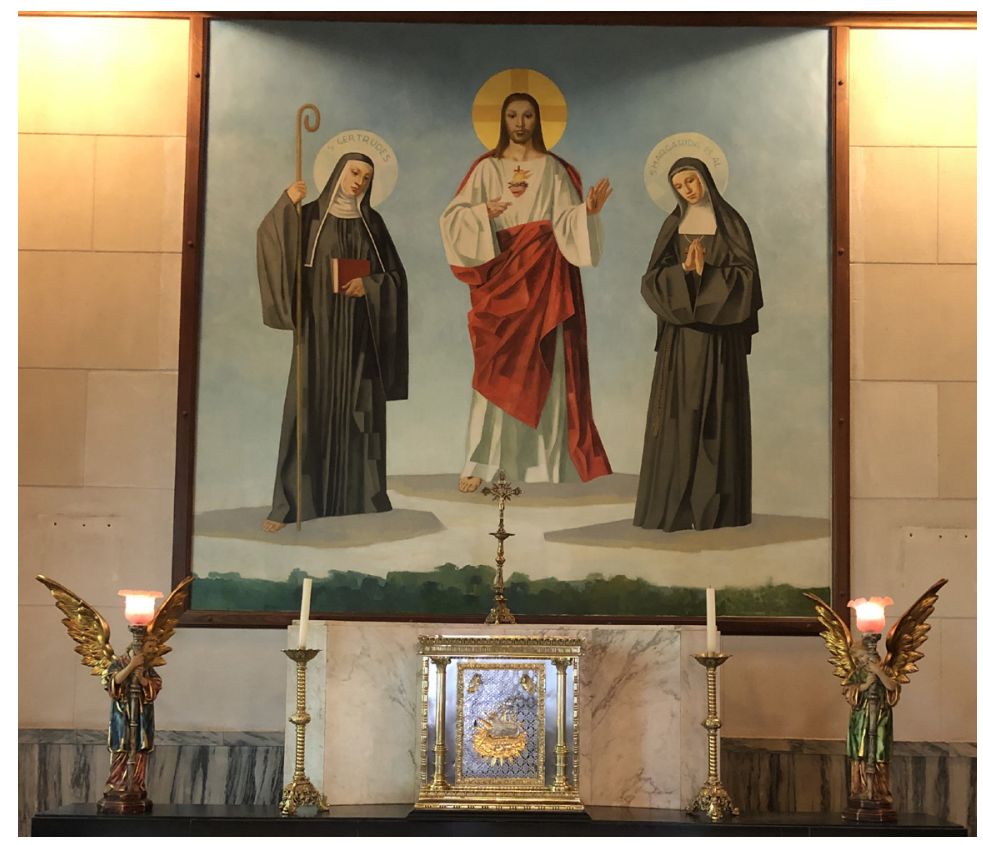

Figura 99: Capela do Santíssimo hoje em dia. Nota-se que nenhum dos croquis apresentados foram realizados. Fonte: Acervo do autor.

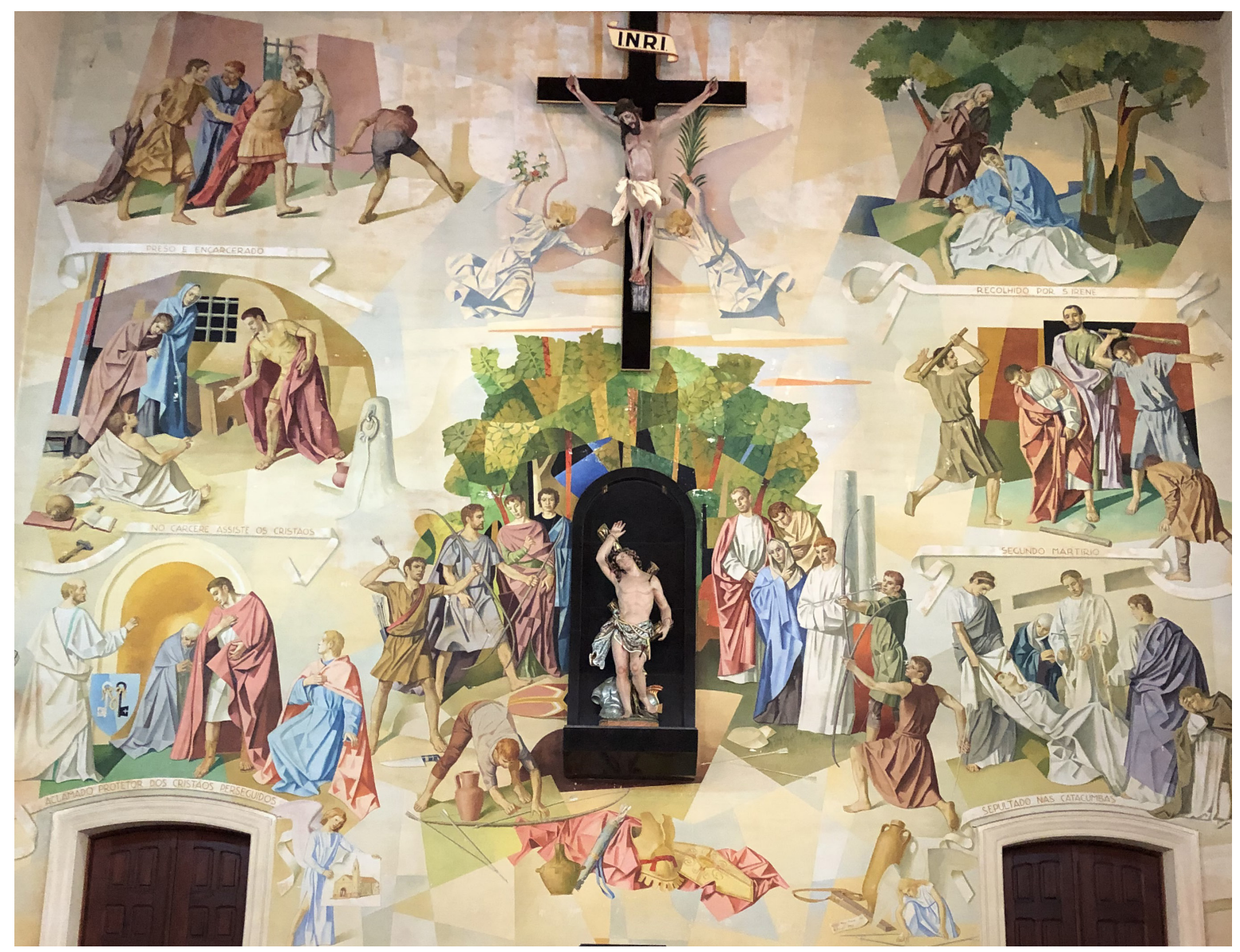

Figura 100: Painel central do presbitério da Igreja Matriz de Porto Ferreira. Nota-se o nicho de granito preto questionado por Nardi. Fonte: Acervo do autor. 


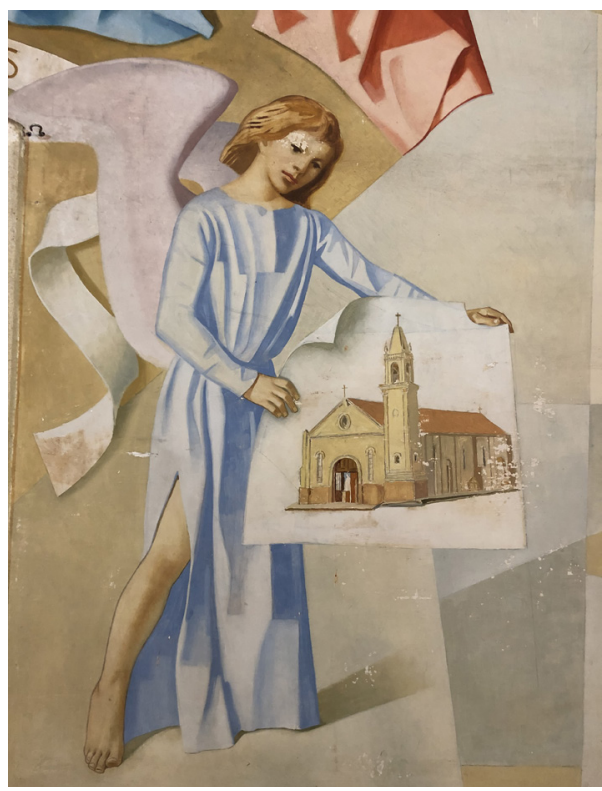

Figura 101: Detalhe da pintura do painel central realizado por Nardi, onde um anjo apresenta a São Sebastião uma flâmula com o desenho da antiga igreja matriz. Fonte: Acervo do autor.

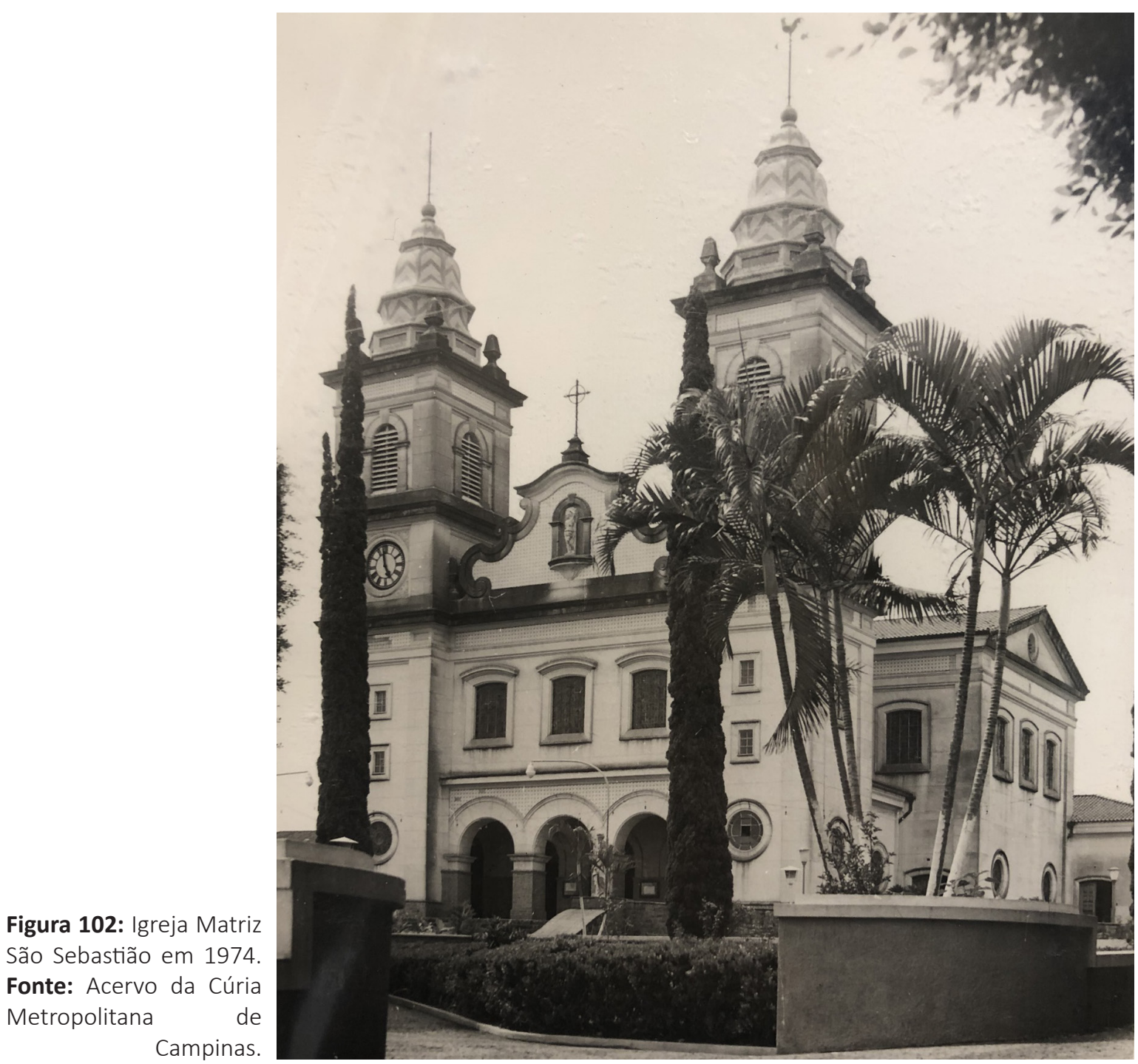



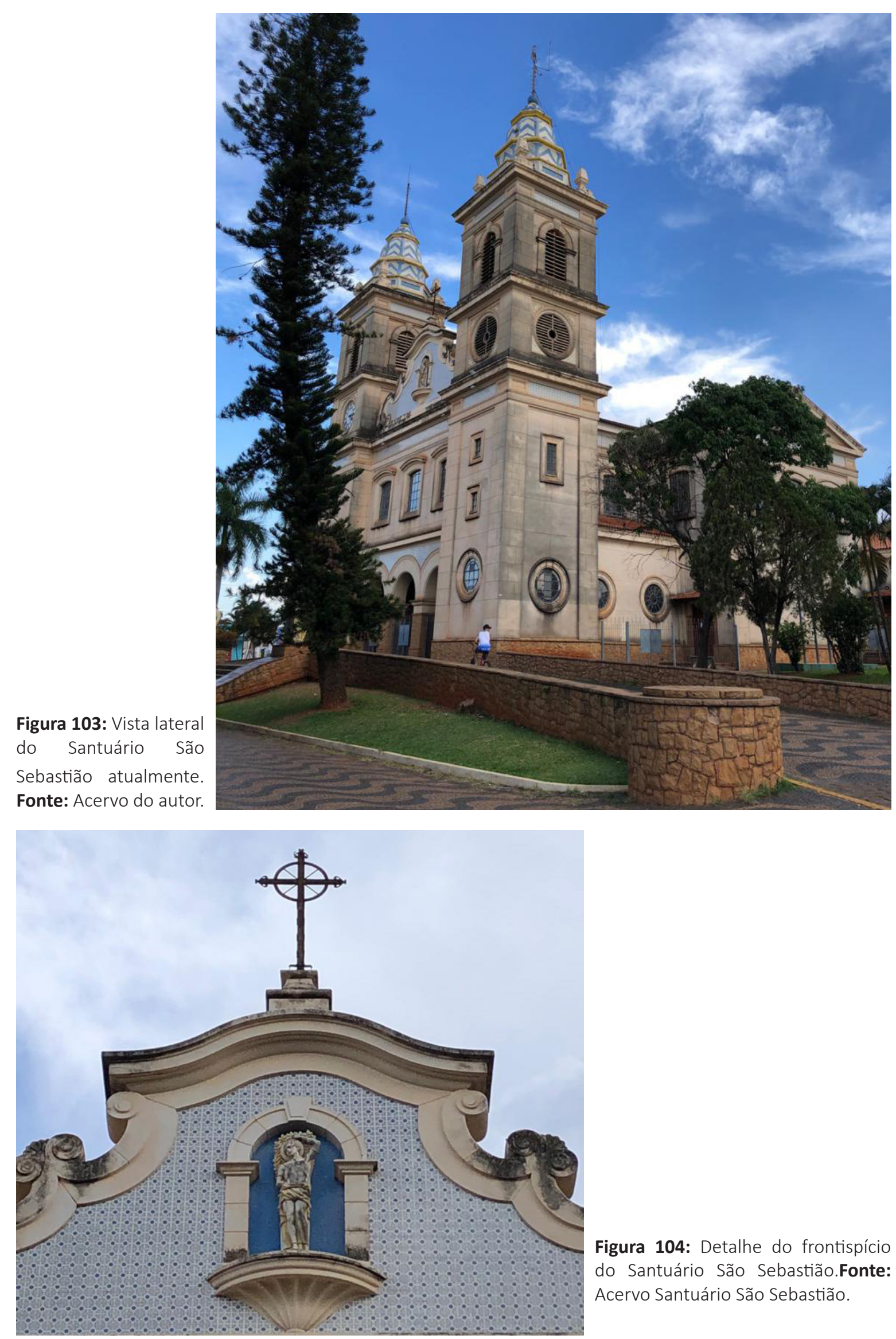

Figura 104: Detalhe do frontispício do Santuário São Sebastião.Fonte: Acervo Santuário São Sebastião. 


\section{A RECONSTRUÇÃO DA IGREJA MATRIZ JESUS CRUCIFICADO, EM IRACEMÁPOLIS}

Como vimos no capítulo 02 (p. 106), a Paróquia Jesus Crucificado, em Iracemápolis, foi instituída em 1936, após reformas na pequena capela de 1891 para torná-la condizente ao status de igreja matriz. Apesar de sua boa conservação, a comunidade católica de Iracemápolis decidiu construir uma nova igreja, diante do progresso pelo qual vinha passando a cidade com a expansão das atividades da Usina Iracema, que consequentemente condicionaram um aumento populacional significativo. "A ideia de uma nova matriz era um pedido do povo e um desejo daqueles que se comprometeram a erguê-la", inclusive a família Ometto, que "colocou à disposição do pároco a ajuda financeira para a construção, desde o primeiro tijolo, até a última telha" (ZANARDO, 2008, p.64).

Em agosto de 1952 foi criada e empossada a Comissão Pró-Obras ${ }^{19}$, cujo trabalho, realizado em diversas frentes, era voltado à arrecadação de recursos para a construção. Dentro da comissão, havia divisões para cada tipo de arrecadação, como por exemplo: arrecadação do Livro de Ouro ${ }^{20}$, arrecadação mensal da vila e arrecadação mensal da zona rural (TOMBO I. JC. p.147). O trabalho de arrecadações iniciou-se em novembro daquele mesmo ano.

A pedra fundamental do novo templo foi lançada em 20 de janeiro de 1953, ainda sem a conclusão do projeto e a escolha definitiva do local de construção ${ }^{21}$. Muitas foram as discussões sobre o sítio no qual deveria assentar-se a nova Igreja Matriz, e em fevereiro a Comissão Pró-Obras decidiu pela compra de um terreno próximo à primitiva capela. Naquele mesmo mês, iniciou-se a construção da nova igreja com a abertura dos alicerces e a colocação das fundações (TOMBO I. JC. p.150).

No que se refere ao projeto da nova igreja, o primeiro projeto ${ }^{22}$ apresentado era de autoria do engenheiro Joaquim Olavo Sampaio ${ }^{23}$, considerado um "progressista que apresentou uma planta linda de estilo moderno" (TOMBO I. JC. p.151), tal como as das igrejas de Leme e Nova Odessa, também por ele projetadas. Porém, após reuniões e discussões, a comissão decidiu

19 Eram integrantes dessa comissão: Virgínio Ometto, Prefeito de Limeira, e José Chinelatto, Prefeito de Iracemápolis.

20 Este tipo de arrecadação aparece registrada no livro tombo com uma comissão de trabalhos especifica, porém, não há detalhes de como esta operava. Relatos orais indicam ser uma comissão destinada a realizar captação de recursos com empresários, fazendeiros e pessoas mais abastadas em geral.

21 A informação de que a pedra fundamental foi lançada sem a escolha do local é um tanto quanto estranha. Geralmente, as pedras fundamentais são depositadas na região onde ficará o presbitério das novas igrejas. No entanto, essa informação está transcrita no livro tombo e não sabemos como se deu essa celebração, e nem onde foi depositado tal símbolo.

22 Apesar de estar referenciado no livro tombo, não foi encontrado nenhum projeto para a Igreja Matriz diferente do construído, nem no acervo da paróquia e nem em buscas do acervo do engenheiro em questão.

23 Engenheiro que atuou em Campinas, responsável pela construção e acabamento de diversas Igrejas na região. Foi professor e fundou em 1941 duas escolas de desenho: a Escola de Desenho e Tecnologia e Escola de Desenho e Pintura, ambas na cidade de Campinas. 
abandonar sem motivos claros o projeto do engenheiro campineiro, ficando a família Ometto responsável por escolher um novo arquiteto e uma nova planta para a nova Igreja Matriz. O projeto escolhido, em estilo neocolonial, foi desenvolvido pelo engenheiro arquiteto Joaquim Bezerra da Silva de São Paulo, e executado pela construtora de Luis Holand, de Piracicaba, também escolhida pelos Ometto.

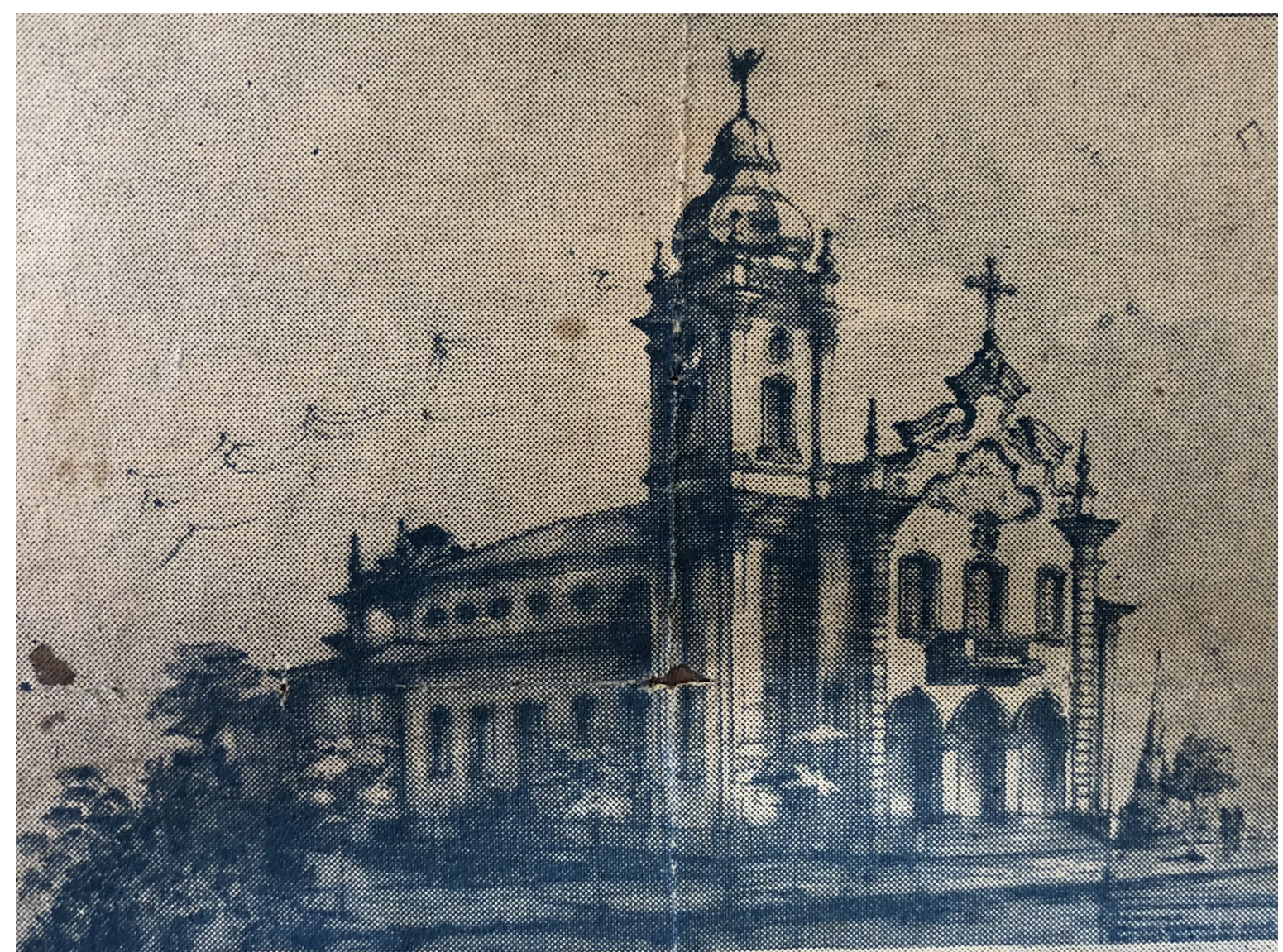

Figura 105: Desenho do projeto da nova Matriz, de feições neocoloniais realizado pelo engenheiro Joaquim Bezerra da Silva, apresentado a Família Ometto. Fonte: Acervo da Paróquia Jesus Crucificado.

O projeto neocolonial apresentava uma torre lateral coberta por uma cúpula bulbosa, e na fachada principal um frontão com volutas e pináculos, além de um painel de azulejos e a galilé, com 3 arcos plenos, encimados por janelas em arco abatido. O corpo central da igreja era iluminado por óculos quadrilobados com vitrais. A planta seguia os padrões encontrados na maioria das igrejas: nave central separada das naves laterais por colunatas; um grande arco cruzeiro delimitando a capela mor; e capelas e altares laterais, além de espaços administrativos na parte posterior. A ornamentação contava com molduras e frisos ao redor de janelas e dos arcos, além do altar central, destinado à colocação das imagens de Jesus Crucificado, Nossa Senhora das Dores e São João Evangelista. 


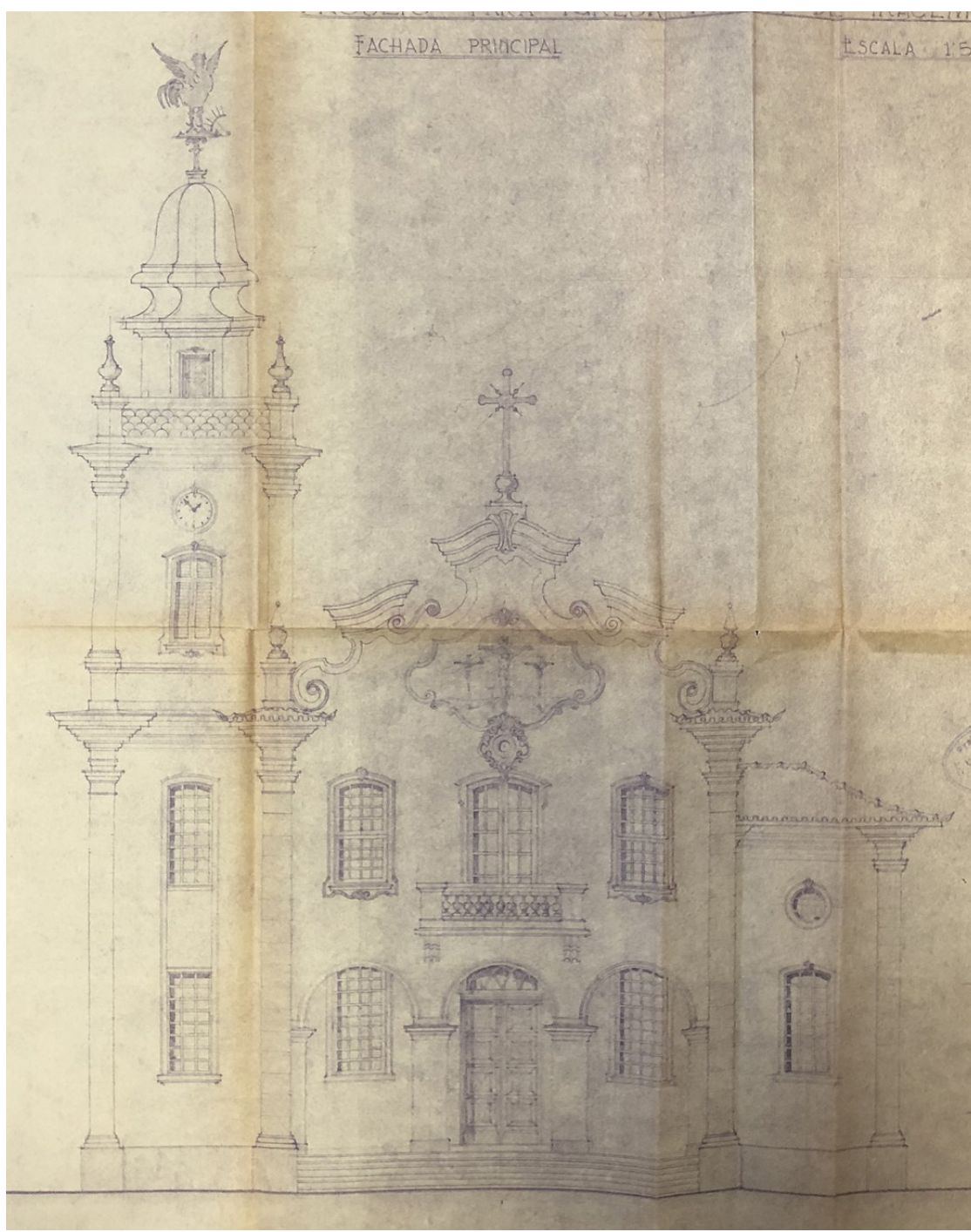

Figura 106: Fachada principal da nova Igreja Matriz nos desenhos do engenheiro Joaquim Bezerra da Silva.

Fonte: Acervo da Paróquia Jesus Crucificado.

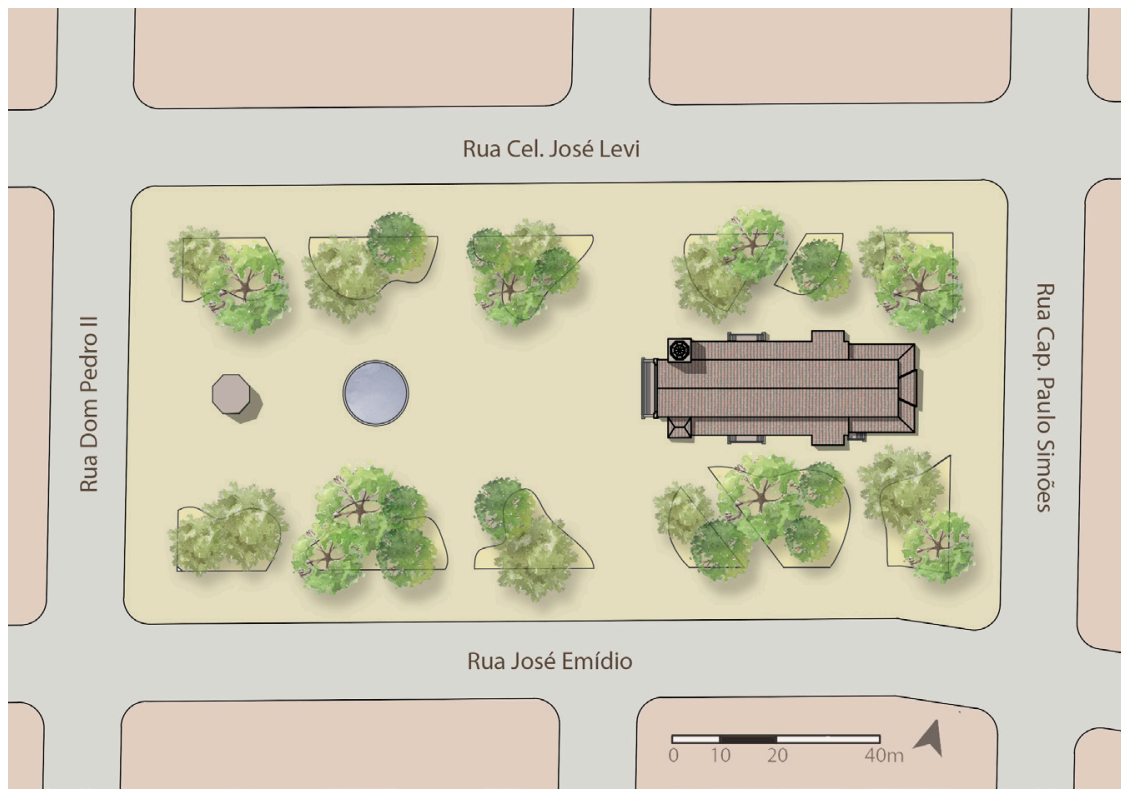

Figura 107: Planta da nova Igreja Matriz de Iracemápolis. Jesus Crucificado. Renan Treft.

Desenho: 


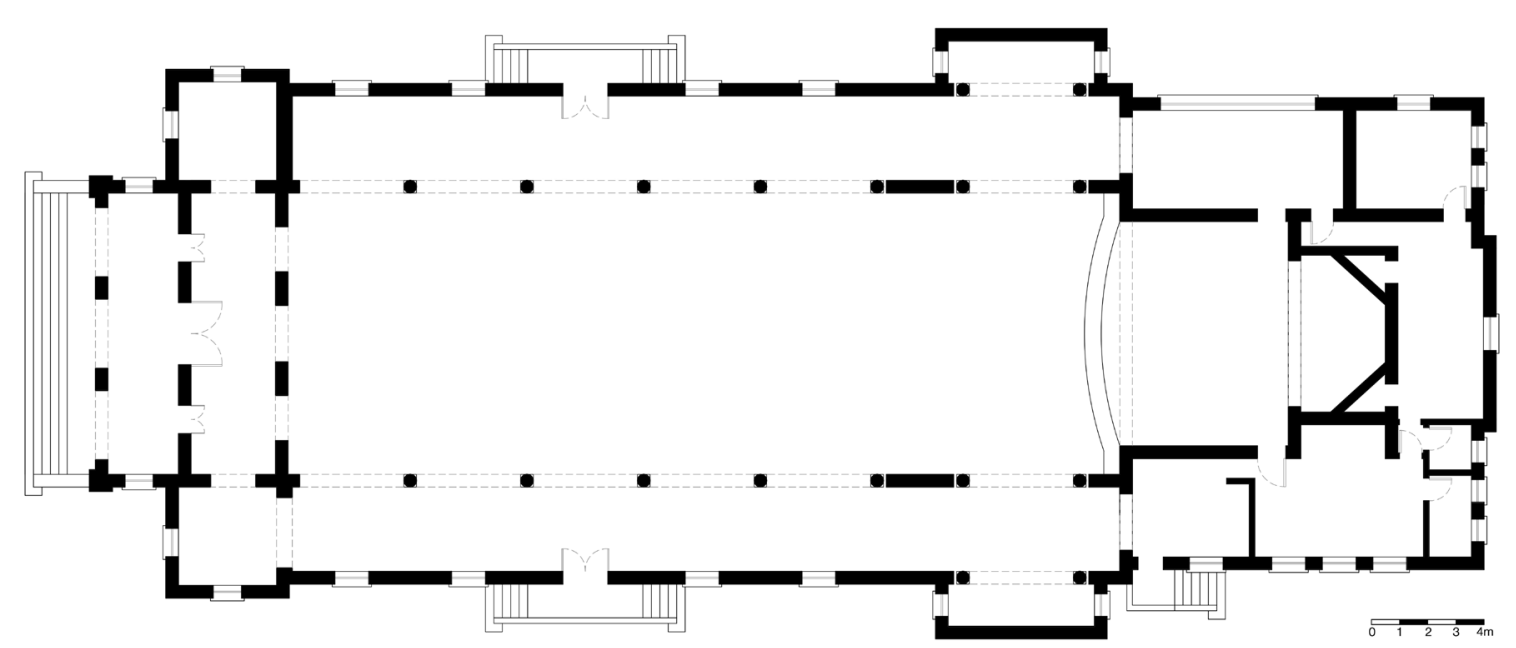

Figura 108: Planta da nova Igreja Matriz de Iracemápolis. Fonte: Baseado no original da Paróquia Jesus Crucificado. Desenho: Renan Treft.

Em dezembro do mesmo ano, o arcabouço do edifício encontrava-se concluído e coberto, o que viabilizou o uso da igreja para as celebrações do natal. No ano seguinte, os trabalhos se concentraram no acabamento e na finalização do novo templo; foram realizadas diversas campanhas para o levantamento de recursos, como a campanha dos vitrais e dos bancos. Os mais abastados da região colaboraram doando imagens, lustres e paramentos, enquanto a Usina Iracema fixou uma doação de acordo com a produção da cana, sendo $\mathrm{Cr}$ 3,00 por tonelada colhida (TOMBO I. JC. p.156).

Na visita pastoral de maio de 1954, o bispo diocesano relata uma "igreja ampla, apreciável obra de arte, digna dos melhores elogios" (TOMBO I. JC. p.158), além de destacar a atuação da comissão de obras e da família Ometto na construção da nova matriz. Em 19 de dezembro do mesmo ano, após solenes celebrações preparatórias, a Igreja Matriz é finalmente inaugurada.

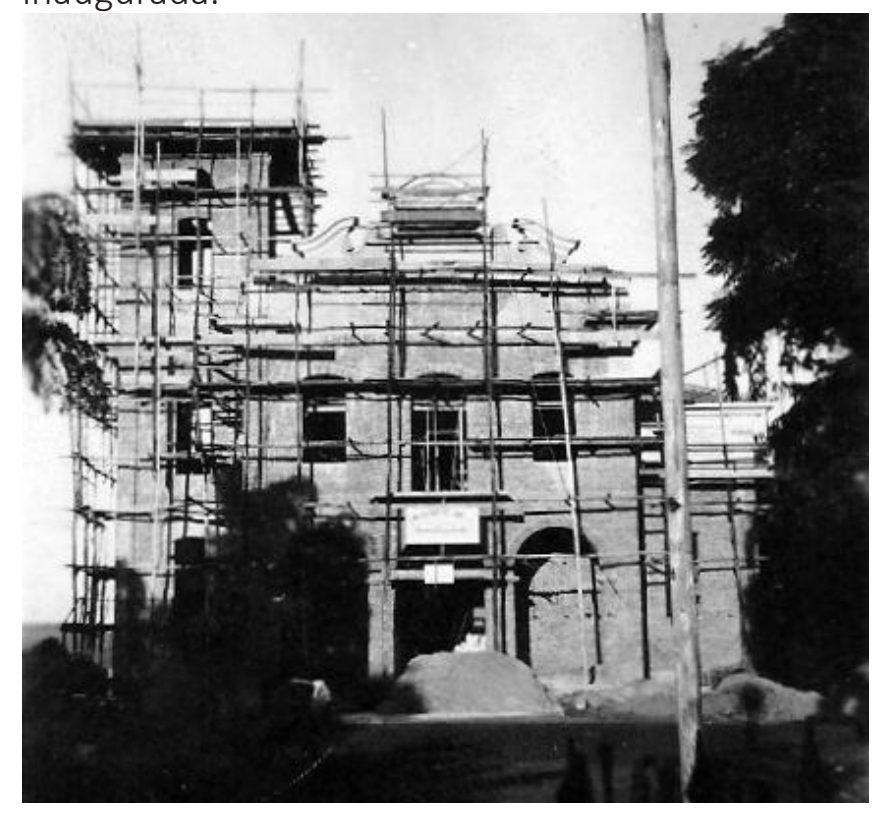

Figura 109: Construção da nova Igreja Matriz em 1953. Fonte: Acervo da Paróquia Jesus Crucificado. 
A antiga igreja, que se localizava na mesma praça da atual Matriz, onde hoje se encontra um coreto, teve sua última missa como parte das preparações para a inauguração da nova Matriz. Após tal celebração, o templo foi totalmente fechado e, em maio de 1955, completamente

demolido:

Aos sons dos sinos pequenos do velho campanário, foi feita a despedida da velha Matriz. Muita gente assistia comovida o "enterro do velho campanário "que descia ao tumulo do passado, ante a poeira que o envolvia. E assim, grande população com desolação assistiu o ultimo desdobrar dos sinos. Era a Igrejinha que se despedia de todos (TOMBO I. JC. p.164).

Depois da inauguração, a Igreja Matriz continuou a receber alguns acréscimos na sua ornamentação, como a colocação de molduras de gesso, a instalação da pia batismal e a pintura final ${ }^{24}$. A realização das atividades de manutenção regulares conferia à Igreja aspectos positivos, conforme registros da visita pastoral de 1961, que descreviam "uma igreja matriz bem estilizada, muito bem cuidada, revelando o zelo dedicado do pároco" (TOMBO I. JC. p.227). No decorrer dos anos, a igreja não sofreu alterações substanciais, apenas instalou um novo altar para atender às demandas da nova liturgia, que foi consagrado em 03 de maio de 1974.

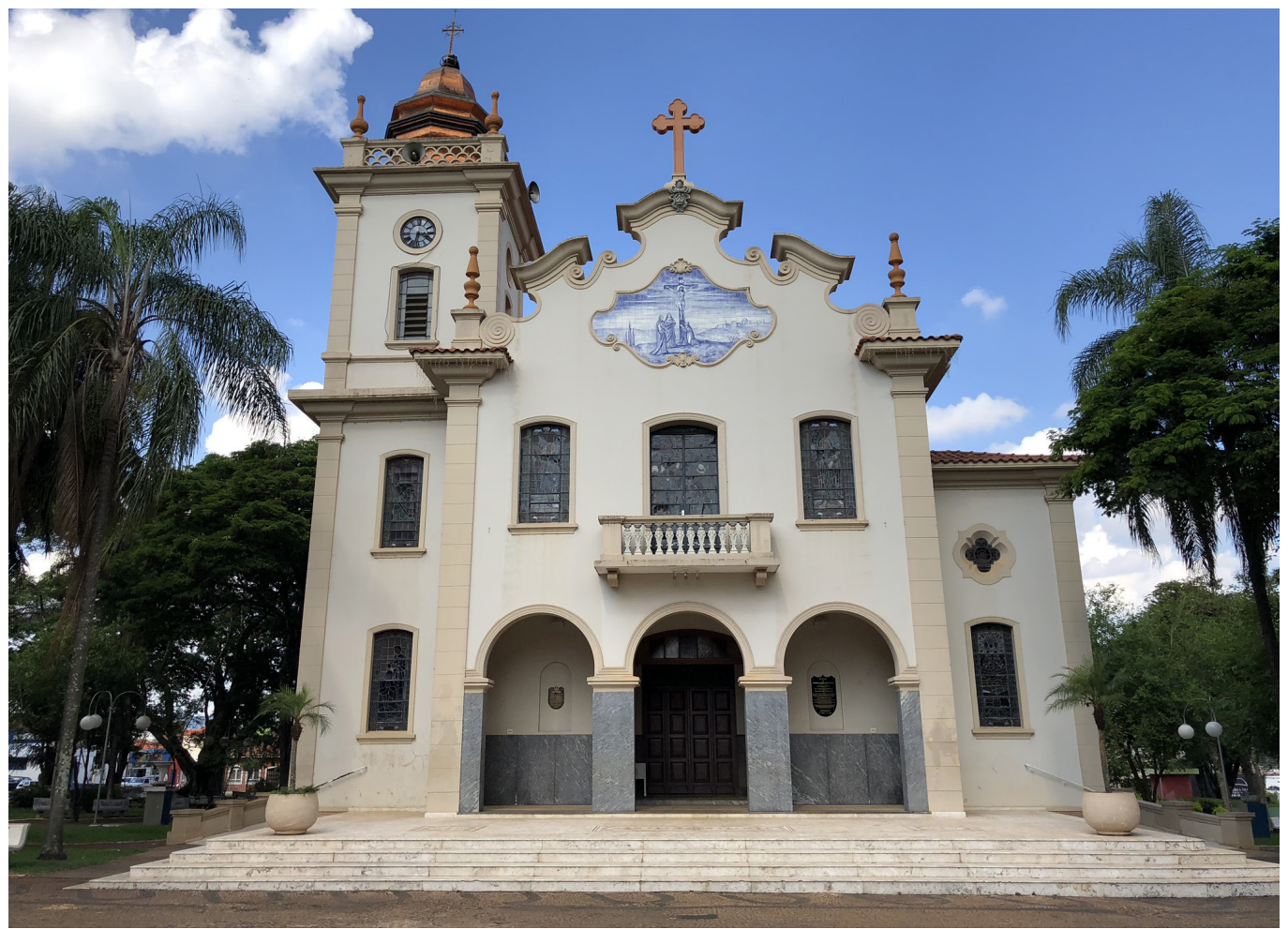

Figura 110: Igreja Matriz Jesus Crucificado em 2019. Fonte: Acervo do autor.

24 O pároco registra no Livro Tombo a existência do "Livro de obras da Matriz Nova" com registros referentes a doações, compras de materiais e a contratação de profissionais, além de atas referentes as reuniões da comissão de obras, contudo o livro não foi encontrado. 


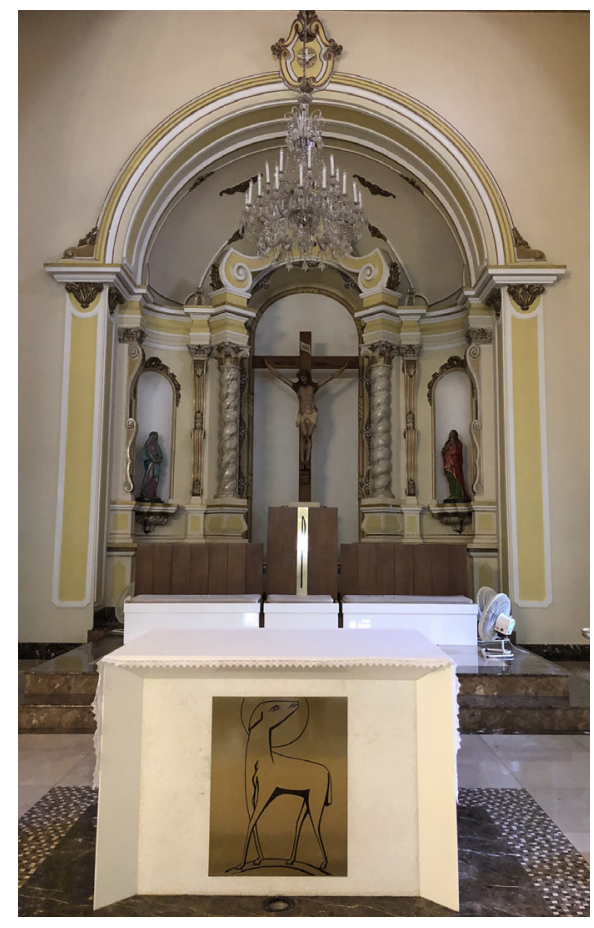

No ano de 2009, a comunidade iniciou os preparativos para a comemoração dos 75 anos de criação da Paróquia, cuja atividade central consistia na reforma total do edifício, preparando-o assim para a efeméride. Foram resolvidos problemas de acessibilidade, com a construção de rampas laterais, e realizadas melhorias técnicas, com a reforma do telhado e a substituição do antigo sistema de iluminação. Nessa ocasião, o antigo piso foi totalmente removido e o mobiliário do presbitério substituído por peças novas, feitas em mármore e de feições contemporâneas, sob justificativa de readequação à nova liturgia. Após a conclusão da reforma, a igreja foi solenemente dedicada no dia 14 de setembro de 2011, nas celebrações da Festa da Exaltação da Santa Cruz.

Figura 111: Presbitério da Igreja Jesus Crucificado. Destaque para o altar e a sédia (cadeira do presidente da celebração) colocados na última reforma.Fonte: Acervo do autor.

\section{A NOVA IGREJA MATRIZ DE COSMÓPOLIS}

Como apontado no capítulo 02 (p.108), a pequena igreja Matriz eclética do distrito de Cosmópolis foi alvo de constantes alterações e melhorias desde sua finalização em 1915, quando o projeto original de Ramos de Azevedo, que havia começado a ser construído em 1901, foi finalmente concluído. A igreja, que estava localizada junto ao loteamento da Usina Ester e afastada do aglomerado populacional presente no Núcleo Colonial, teve seu entorno plenamente ocupado somente em 1946 (TOMBO III. SG. p.06).

As primeiras manifestações evidenciando o desejo de se construir uma nova igreja matriz, com porte adequado à cidade que Cosmópolis estava se tornando, e para o melhor desempenho das atividades religiosas, decorrem da necessidade de constantes reformas no edifício original para adequá-lo às características de uma igreja matriz, além do incômodo gerado por sua incapacidade de acomodar o crescente número de fiéis cosmopolenses. No ano de 1949, o então pároco, padre João Batista Germano Prado, relata o entusiasmo da comunidade com o projeto de um novo templo, o qual a Usina Ester novamente havia se comprometido a ajudar financeiramente, além de seus proprietários e gerentes comporem a comissão pró-obras:

Estamos na esperança para construir a nova lareja Matriz. O povo está entusiasmado. A Usina Ester veio ao nosso encontro. As plantas foram confeccionadas pelo Dr. Mario Penteado sendo a comissão integrada por elementos como: Dr. Paulo Nogueira, Dr. 
Paulo Nogueira Neto, Guilherme Nogueira, Dr. João Hereman (Prefeito Municipal), Pedro Leussoni, Manuel Rodrigues e outras pessoas de boa vontade (TOMBO III.SG. p.25). [grifo nosso]

O projeto também foi entregue aos cuidados do arquiteto Mário Penteado, tal como em Limeira, e submetido à aprovação da Cúria Diocesana. Enquanto não se tinha o aval necessário, a Comissão Pró Obras trabalhava para levantar fundos para o início do empreendimento. A Usina Ester iniciou também o pagamento de parcelas pró-construção no valor de cem mil cruzeiros $^{25}$.

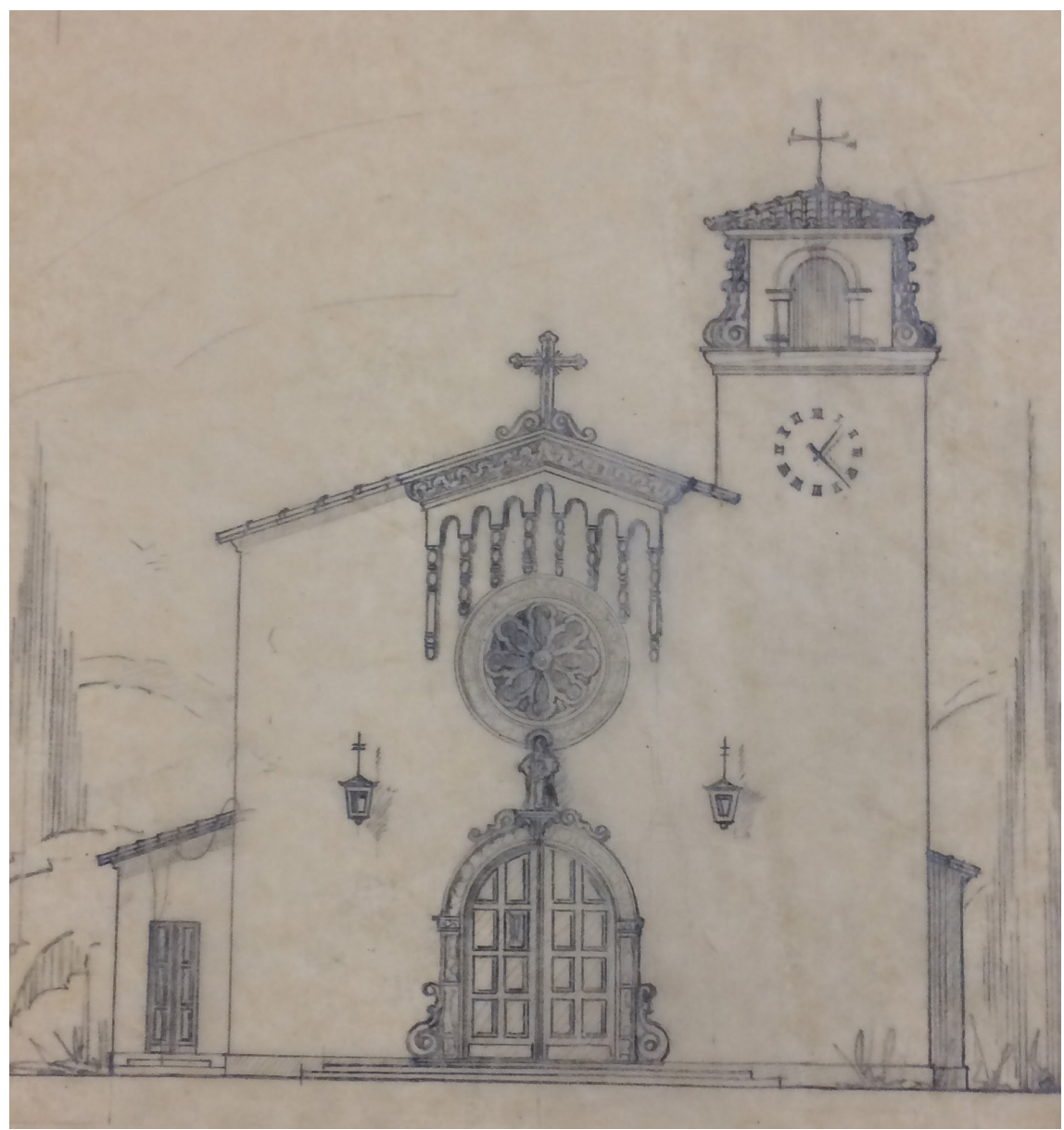

Figura 112: Primeiro estudo realizado para a Igreja Santa Gertrudes. Todo o conjunto da fachada era alinhado num mesmo plano e a ornamentação simplificada. Fonte: Centro de Apoio Didático da PUC Campinas.

25 O pároco registra o pagamento das parcelas, mas não menciona por quanto tempo elas deveriam acontecer (TOMBO III. SG.p.27v). 


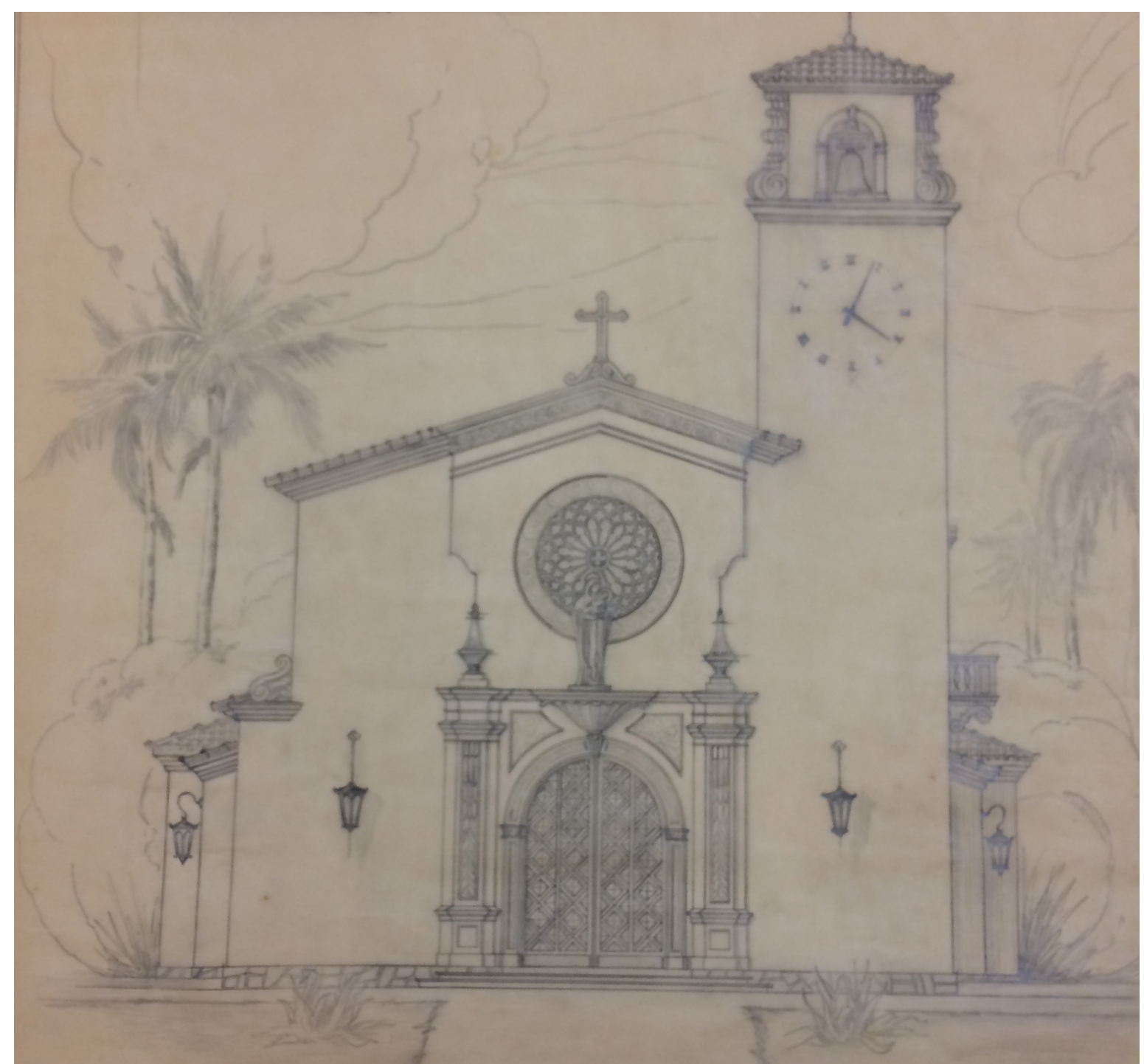

Figura 113: Fachada da nova Igreja Matriz Santa Gertrudes. Versão final.Fonte: Centro de Apoio Didático da PUC Campinas.

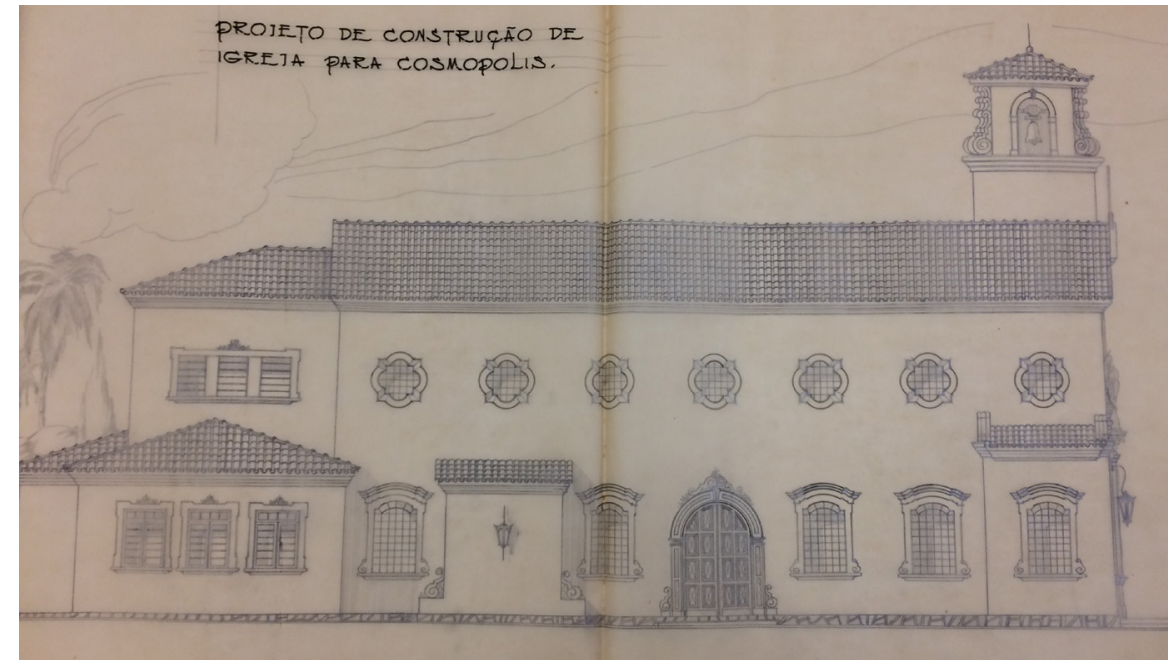

Figura 114: Fachada lateral da nova Igreja Matriz Santa Gertrudes. Fonte: Centro de Apoio Didático da PUC Campinas. 


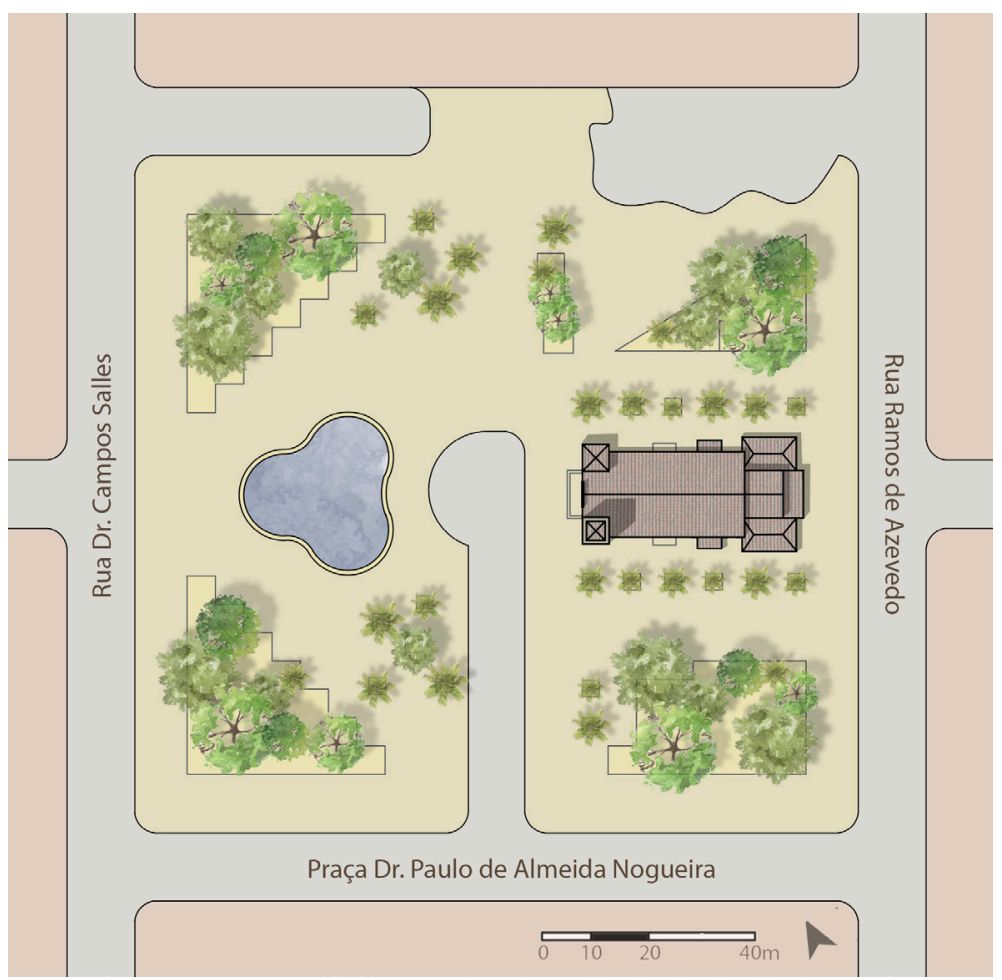

Figura 115: Implantação da Igreja Santa Gertrudes na Praça Dr. Paulo de Almeida Nogueira. Desenho: Renan Treft.

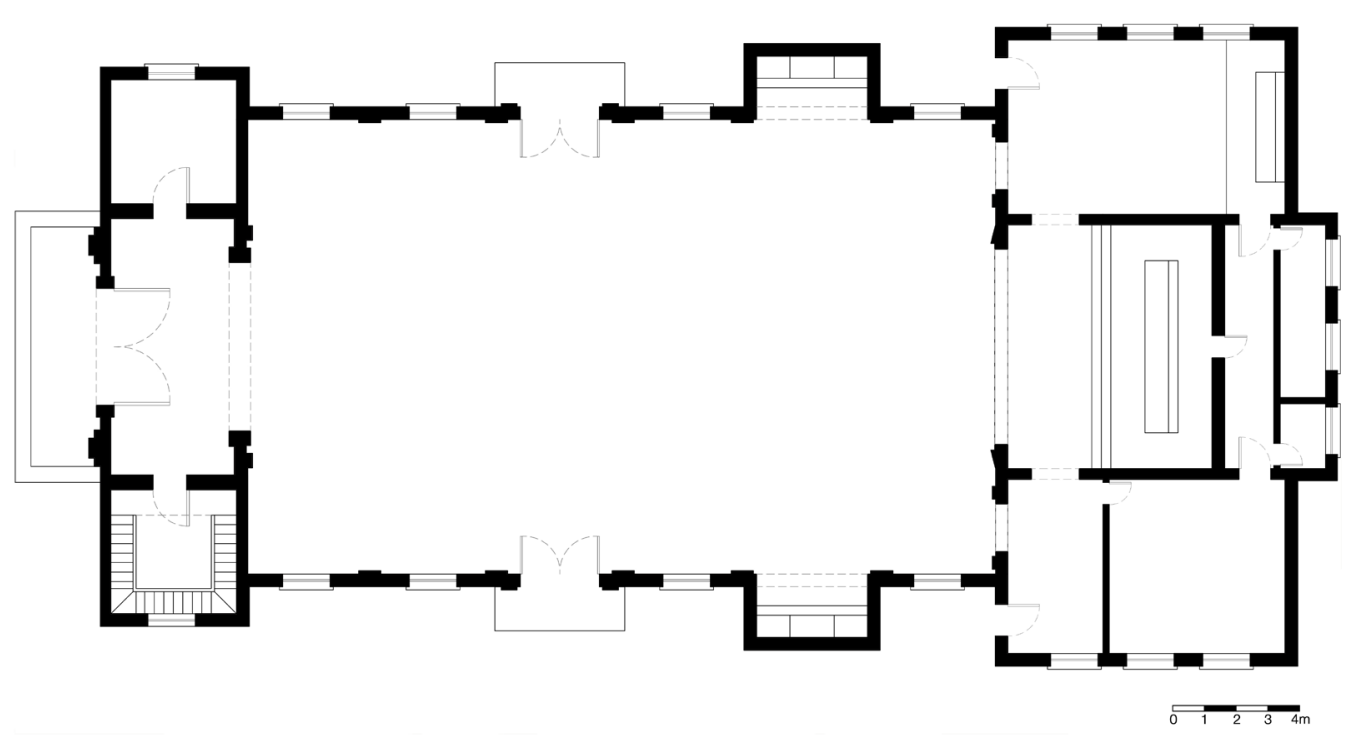

Figura 116: Planta da nova Igreja Matriz Santa Gertrudes, onde é possível identificar um espaço destinado ao culto litúrgico mais completo que o da primitiva capela, com a presença de nichos para alteres laterais, uma generosa capela-mor e um átrio para transição com o espaço público, além de largas aberturas e espaços para suporte técnico. Fonte: Baseado no original do Centro de Apoio Didático da PUC Campinas. Desenho: Renan Treft.

Foi na visita pastoral de 15 de maio de 1950 que o bispo de Campinas, Dom Paulo de Tarso Campos, deu o aval positivo para a construção de sua nova Matriz em Cosmópolis. O relatório gerado nesta ocasião comenta o projeto e seu porte, além de elogiar o arquiteto Mario Penteado, membro da elite de Campinas, com qual a bispo diocesano mantinha 
relações próximas. Os préstimos realizados pela Usina Ester para a comunidade católica de Cosmópolis também são comentados:

Aprovamos e abençoamos de todo o coração o projeto de construção de uma nova Matriz, mais ampla e provida de todas as dependências necessárias aos trabalhos paroquiais. A planta, que já aprovamos, de autoria do respeitado arquiteto campineiro: Dr. Mario Penteado, corresponde a essas necessidades. Esperamos que em breve se possa iniciar esse trabalho, que sem dispensar a cooperação de todos os paroquianos, sabemos que será generosamente amparado pelos diretores da Usina Ester (TOMBO III. SG. p.29v). [grifo nosso]

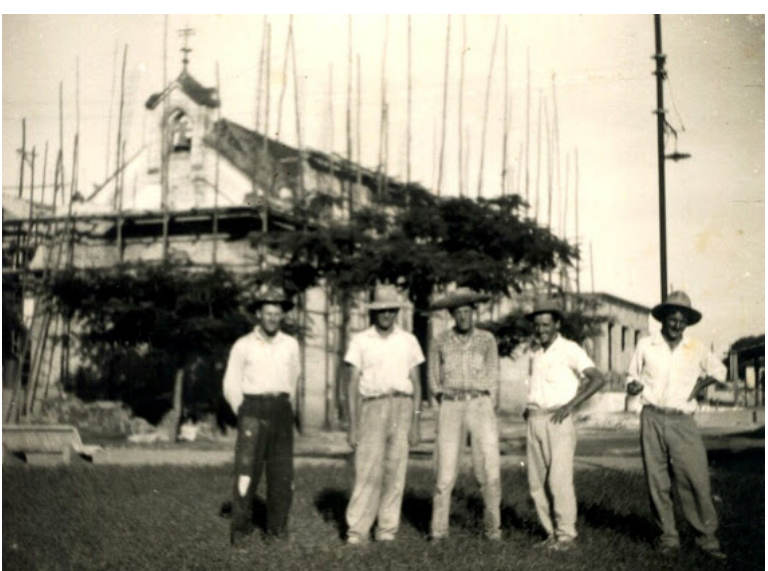

Figura 117: Obras da nova Matriz ao redor da antiga capela em 1951.Fonte: Acervo da Paróquia Santa Gertrudes.

O projeto, no estilo missões, demorou para começar a ser construído; somente no dia 27 de maio de 1951 foi realizada a missa para a colocação da pedra fundamental da nova matriz. A construção iniciou-se em volta do antigo templo, para evitar a sua demolição. As grandes paredes da nova matriz logo esconderam a velha igrejinha eclética de 1901. O projeto da nova igreja apresentava em sua fachada uma única torre lateral alinhada com o corpo principal da igreja, e arrematada por um campanário de projeção reduzida em relação à torre. Além disso, a disposição dos ornamentos e a forma das envasaduras conferem ao edifício feições do neocolonial em sua variação do estilo missões.

As obras, que eram em sua maior parte financiadas pela Usina Ester, foram paralisadas diversas vezes por falta de recursos. A dinâmica da empresa ditava o ritmo da construção, tornando-a dependente dos resultados dos negócios (TOMBO III. SG. p.153v). Após findaremse os recursos existentes, as obras foram paralisadas no final de 1953 e retomadas, ainda que lentamente, apenas em setembro de 1955 (TOMBO III. SG. p.41v).

Em 1957, foi realizado o contrato para a cobertura da nova igreja cujas paredes encontravamse prontas. Para isso, foi necessário demolir a antiga matriz que ainda estava em uso e passar os serviços religiosos para o salão paroquial (TOMBO III. SG. p.43). Após a conclusão dos serviços de cobertura, a nova matriz começa a ser preparada para ser inaugurada, mesmo sem estar totalmente finalizada. A primeira celebração na nova igreja foi realizada em 19 de novembro de 1958.

Apesar de estar sendo utilizada, as obras ainda não tinham sido concluídas, nem na parte estrutural e nem quanto aos acabamentos externos e internos. O mobiliário ainda era proveniente da antiga igreja e em nada combinava com o novo edifício. No entanto, as obras 
ficaram paralisadas até a chegada do novo pároco, Monsenhor João Batista Rigotti, que assumiu a liderança da paróquia em 20 de outubro de 1959.

"Uma Igreja sólida, grande - mas não muito, devia ser maior, pelo futuro da paróquia - estilo colonial, portas muito sólidas e artísticas" (TOMBO III. SG. p.55), são as descrições realizadas pelo recém empossado pároco no livro tombo, referentes a inacabada Igreja Matriz neocolonial. Além disso, o sacerdote comenta sobre os futuros desafios para sua conclusão, como o término da construção da torre e a colocação dos sinos, os acabamentos internos e externos e a substituição total dos mobiliários e objetos sacros. "A substituição

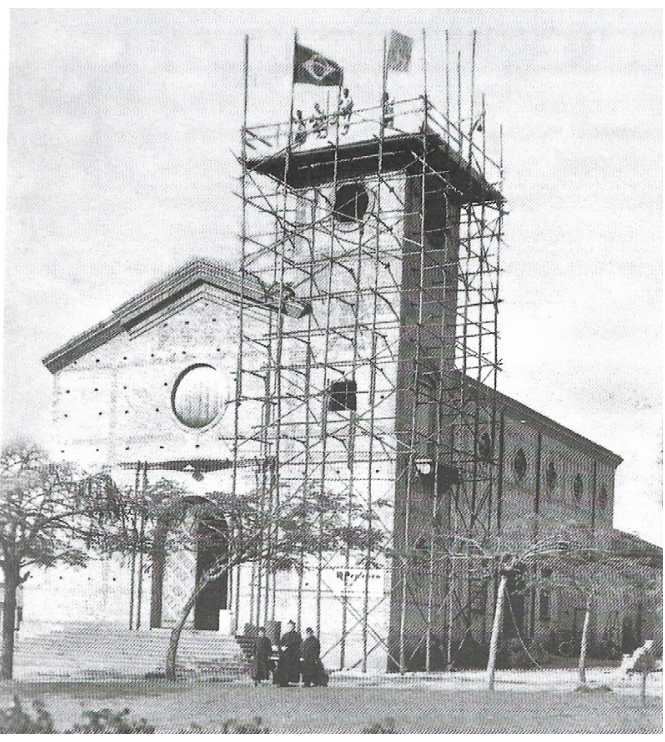

Figura 118: Continuação da construção da nova Matriz em meados de 1962, agora com a torre parcialmente concluída. Fonte: FERREIRA, 2011, p. 281. da Matriz velha pela nova, dá a impressão de Cosmópolis ser ainda uma paróquia em formação" (TOMBO III. SG. p.55), concluiu o novo pároco.

Os primeiros trabalhos da nova gestão são voltados à reestruturação da comissão de obras, à colocação de novos bancos e ao lançamento de uma nova campanha para angariar fundos ${ }^{26}$. Novamente a questão financeira volta a incomodar a comunidade católica cosmopolense, e a Usina Ester é mais uma vez convidada a colaborar com doações.

Somente no ano de 1962 a torre ficará pronta, o relógio será instalado e uma cruz de cimento será colocada na fachada principal, no ponto da cumeeira (TOMBO III. SG. p.61). Porém, as obras foram novamente paralisadas. O motivo desta vez foi devido à destinação de recursos para a reforma de uma casa para acolhida de uma congregação

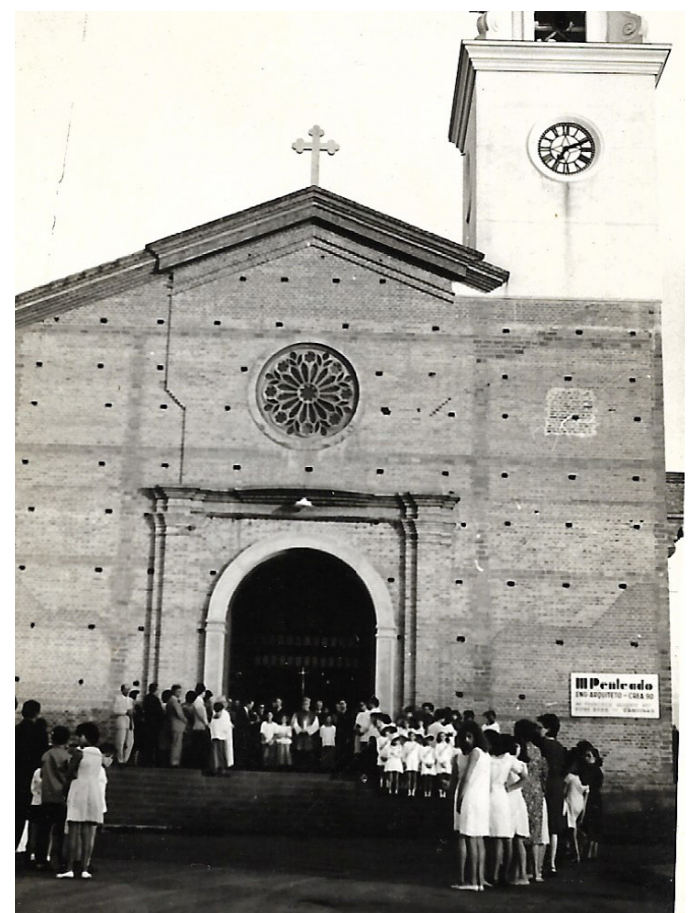

Figura 119: Fachada da Igreja Matriz já com a torre concluída, mas ainda faltando os acabamentos. Detalhe para a placa com o logotipo do escritório do arquiteto Mario Penteado fixado junto à construção.Fonte: Acervo da Paróquia Santa Gertrudes.

26 A colocação dos novos bancos resultou de uma campanha realizada pelo pároco denominada "Campanha dos 100 bancos". A nova diligência foi chamada de Campanha do Milhão de Cruzeiros e foi lançada para toda população (TOMBO III. SG. p.56v). 
religiosa feminina por ordem do bispo diocesano. Na visita pastoral de 1965, o bispo local relata que fiscalizou a Igreja Matriz em construção, e que suas obras deveriam ser retomadas assim que fossem concluídas as obras de caráter social ${ }^{27}$.

O acabamento interno da Igreja foi iniciado em 1967, estando o altar mor pronto em 1968. Para a finalização das demais partes, a paróquia recorreu à Prefeitura Municipal, que através de um auxílio financeiro, viabilizou a conclusão desta etapa em 1969. Os trabalhos incluíam o reboco de todas as paredes, a colocação de trabalhos artísticos nas colunas e arcos e molduras nos vitrais. A iluminação foi realizada através de doações dos munícipes (TOMBO III. SG. p.73v). Em outubro iniciou-se o assentamento do piso a partir da capela mor com fundos oriundos de uma campanha, na qual cada paroquiano era convidado a doar $1 \mathrm{~m}^{2}$.

Em março de 1970 são iniciados os trabalhos para o acabamento da fachada da Matriz, novamente com a colaboração da Prefeitura Municipal (TOMBO III. SG. p.78). É interessante notar o distanciamento da iniciativa privada e a aproximação da iniciativa pública no financiamento das obras religiosas. A igreja não foi totalmente concluída segundo o projeto original, tendo sua ornamentação bastante simplificada, provavelmente devido à escassez de recursos disponíveis.

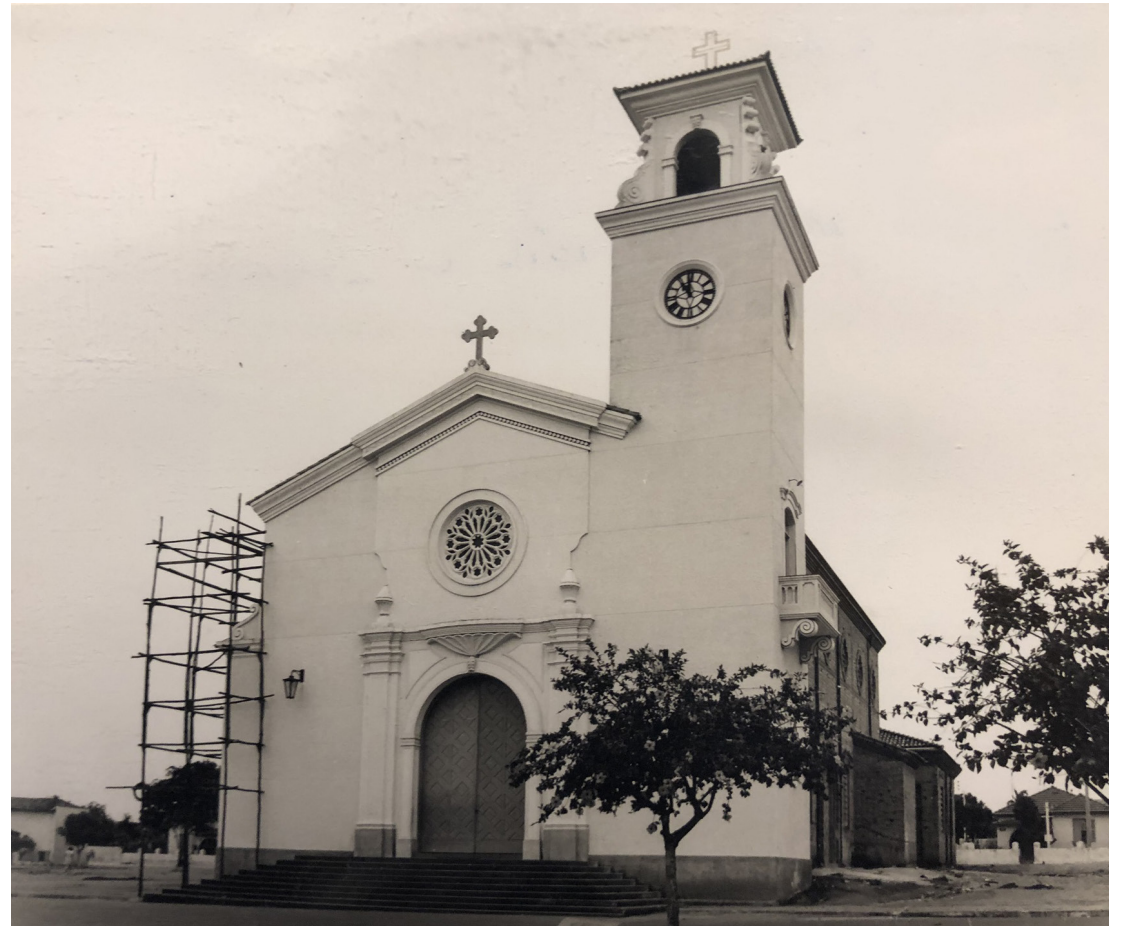

Figura 120: Igreja Matriz Santa Gertrudes em 1975. Fonte: Acervo da Cúria Metropolitana de Campinas.

27 A Congregação Nossa Senhora do Calvário (Irmãs Calvarianas) foi instalada em Cosmópolis no dia 16 de março de 1967 e empossada em 20 de janeiro de 1968. Destinava-se a colaborar na evangelização e no trabalho pastoral da Paróquia, visitando as capelas e atendendo aos necessitados. A Usina Ester realizou a doação de um antigo prédio do Posto de Puericultura para servir de alojamento das irmãs. 
As mudanças nos preceitos litúrgicos alteraram drasticamente o interior do edifício, pois, além da adequação ao novo rito, o processo de acabamento e construção dos altares ficou comprometido devido à ausência de um projeto que atendesse às novas demandas. Com isso, a igreja sofreu uma série de intervenções em seu interior ao longo dos anos; os espaços deixados em desuso pela nova liturgia foram readaptados a novos serviços e novos elementos foram acrescentados em sua ornamentação, como a construção de um baldaquino na capela-mor e novas peças em mármore para o altar. Somente no ano de 2015 a igreja foi solenemente consagrada.

Figura 121: Igreja Santa Gertrudes em 2019. Fonte: Acervo do autor.

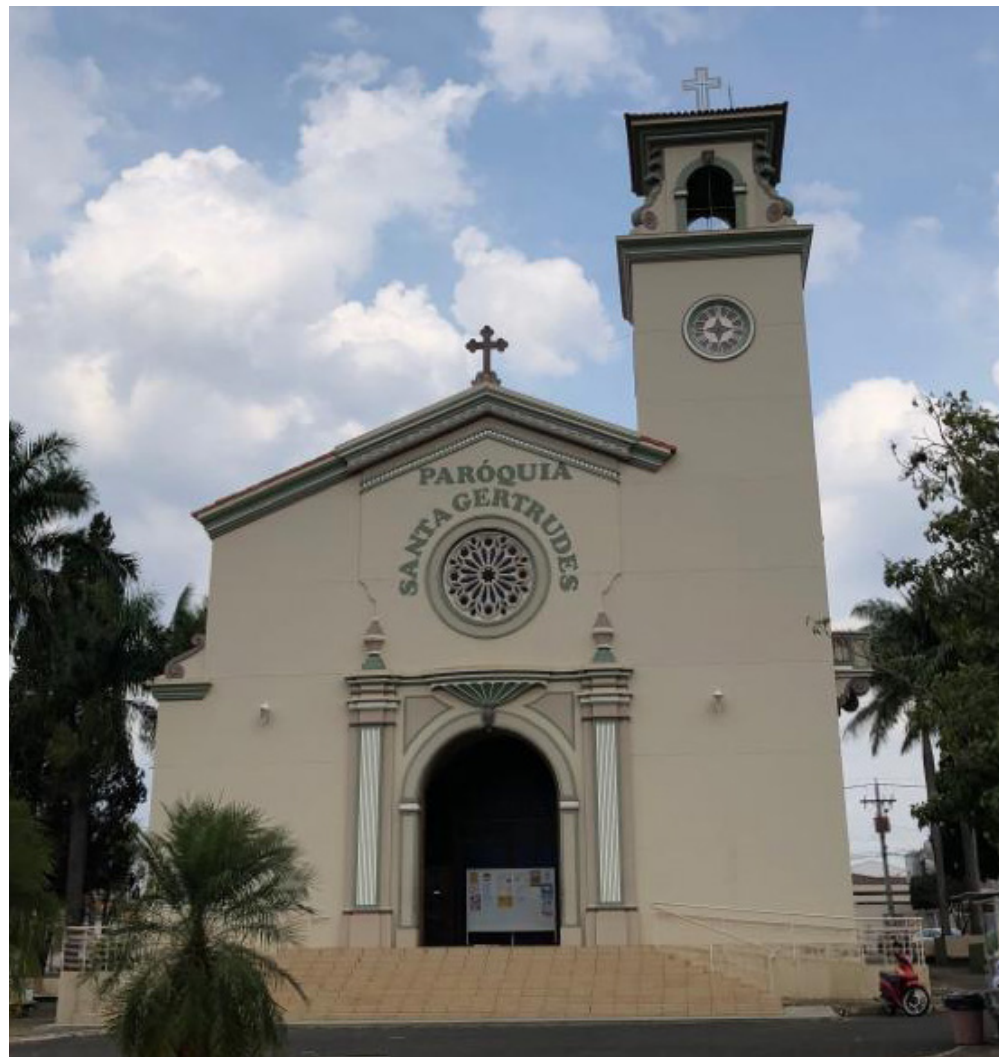

Figura 122: Interior da Igreja Santa Gertrudes em 2019.Fonte: Acervo do

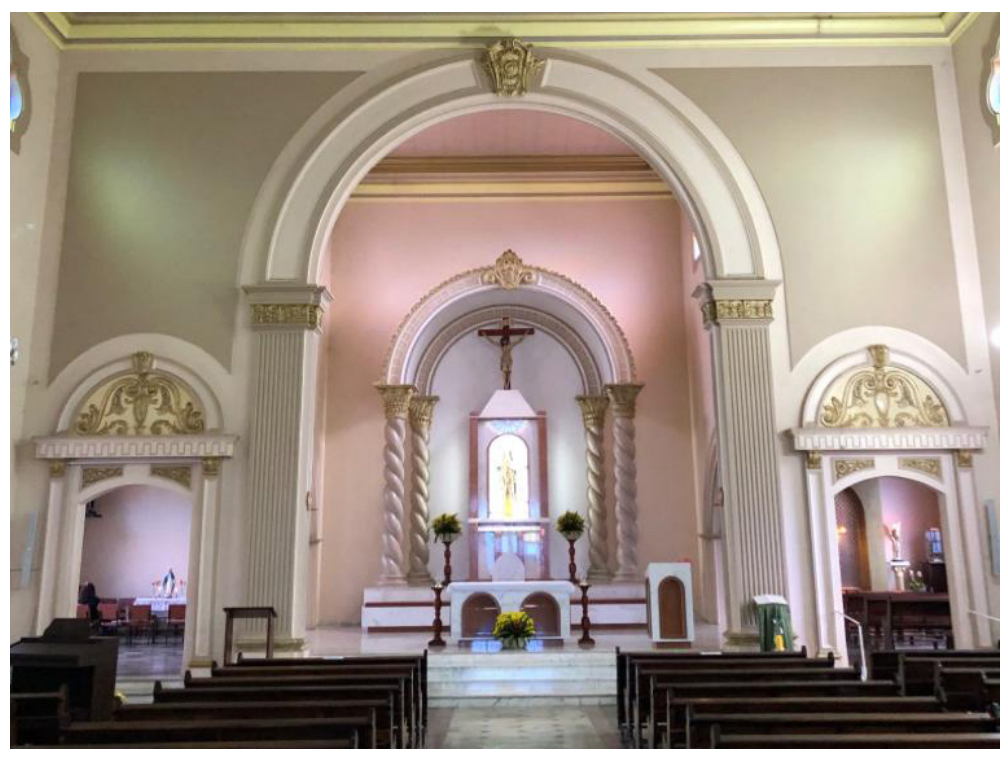
autor. 


\section{3 - OUTRAS IGREJAS NEOCOLONIAIS EXISTENTES NA DIOCESE DE LIMEIRA}

Além das igrejas matrizes apresentadas neste estudo, existem outras capelas construídas em neocolonial no território da Diocese de Limeira. São igrejas de menor porte e que estão vinculadas a algum serviço ou entidade privada, cuja construção se deu em período anterior ou concomitante ao da reconstrução das igrejas matrizes. Há ainda algumas pequenas capelas rurais, que foram reformadas ou construídas utilizando elementos próprios da arquitetura neocolonial, porém de forma simplificada.

\section{CAPELA JESUS CRUCIFICADO - CEMITÉRIO SAUDADES LIMEIRA}

A Capela Jesus Crucificado foi construída no cemitério da Saudade pela Confraria da Boa Morte, no pequeno trecho da necrópole que ficou para a irmandade, após a municipalização e laicização dos cemitérios ocorrida com o advento da República. O projeto é de autoria de Mário Penteado, porém, muito diverso dos realizados por ele para as igrejas matrizes. A pequena capela neocolonial apresenta estrutura semelhante às capelas bandeiristas do estado de São Paulo, cujo repertório é distante do estilo missões aplicadas nas outras construções religiosas do mesmo arquiteto. Após a conclusão das obras, a capela foi inaugurada em 02 de novembro de 1943.

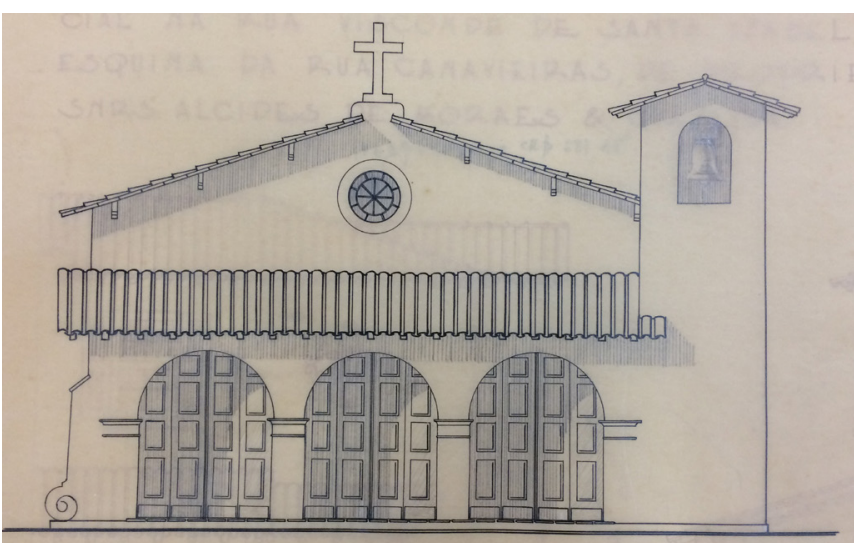

Figura 123: Elevação da Capela Jesus Crucificado do Cemitério Saudades de Limeira.Fonte: Centro de Apoio Didático da PUC Campinas.

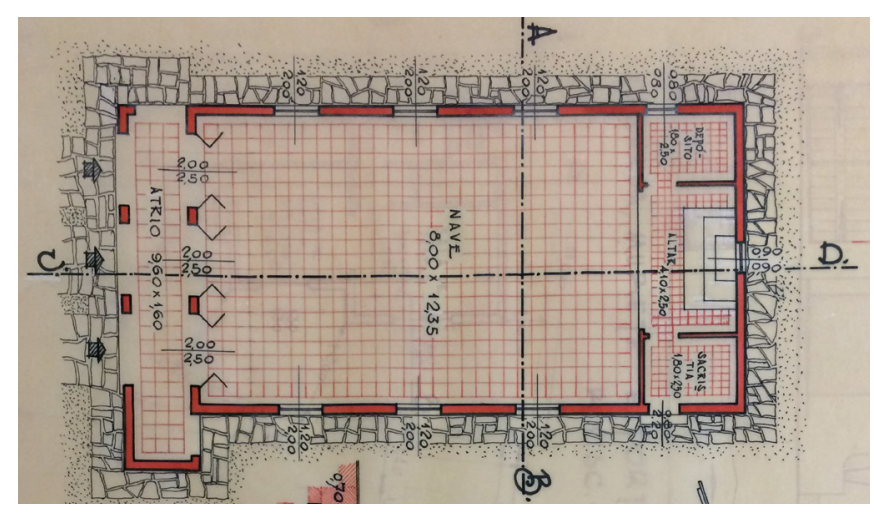

Figura 124: Planta da Capela Jesus Crucificado do Cemitério Saudades de Limeira. Fonte: Centro de Apoio Didático da PUC Campinas. 
Figura 125: Capela do Cemitério Saudades de Limeira em 2020

Fonte: Acervo do autor

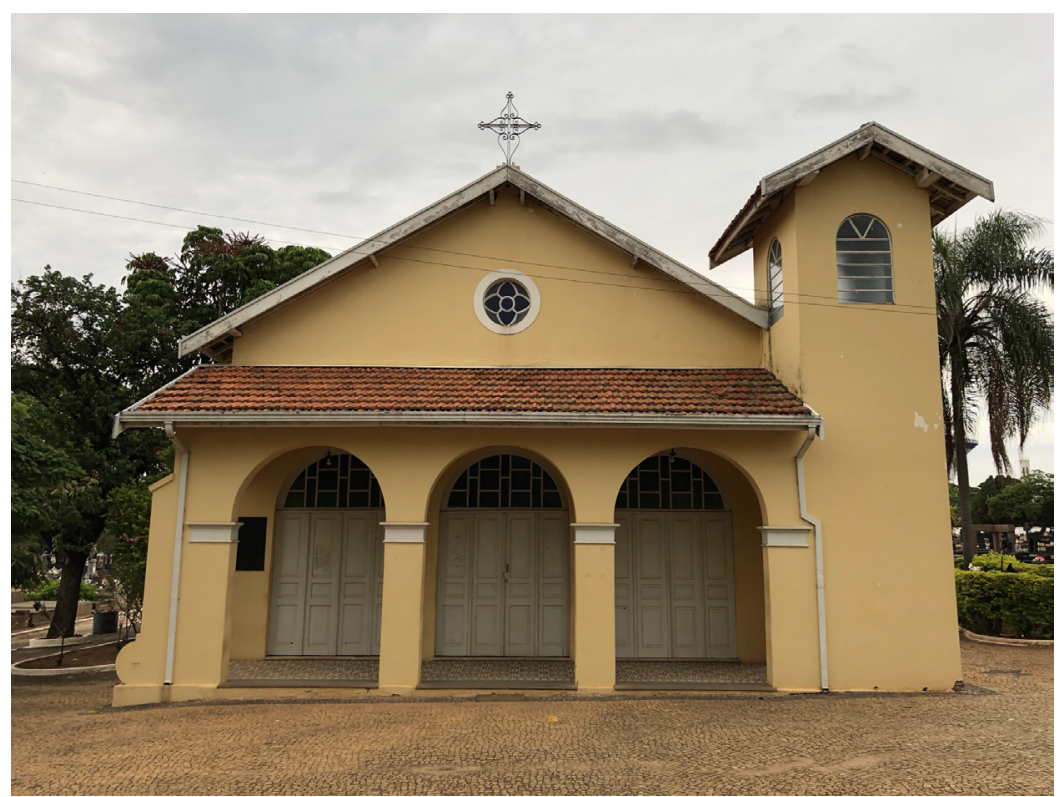

\section{CAPELA SÃO JUDAS TADEU - LEME}

Em 1944, o pároco de Leme, Cônego Manoel Simões, o mesmo que empreendera as obras da Matriz de Santa Cruz da Conceição, pediu autorização ao bispo diocesano para adquirir um terreno na região periférica de Leme para construir uma capela dedicada a São Judas Tadeu, que foi projetada pelo engenheiro-arquiteto Lix da Cunha. O engenheiro apresentou duas propostas para a fachada da capela, ambas em estilo neocolonial. O modelo nomeado como "B" foi escolhido para a construção28.
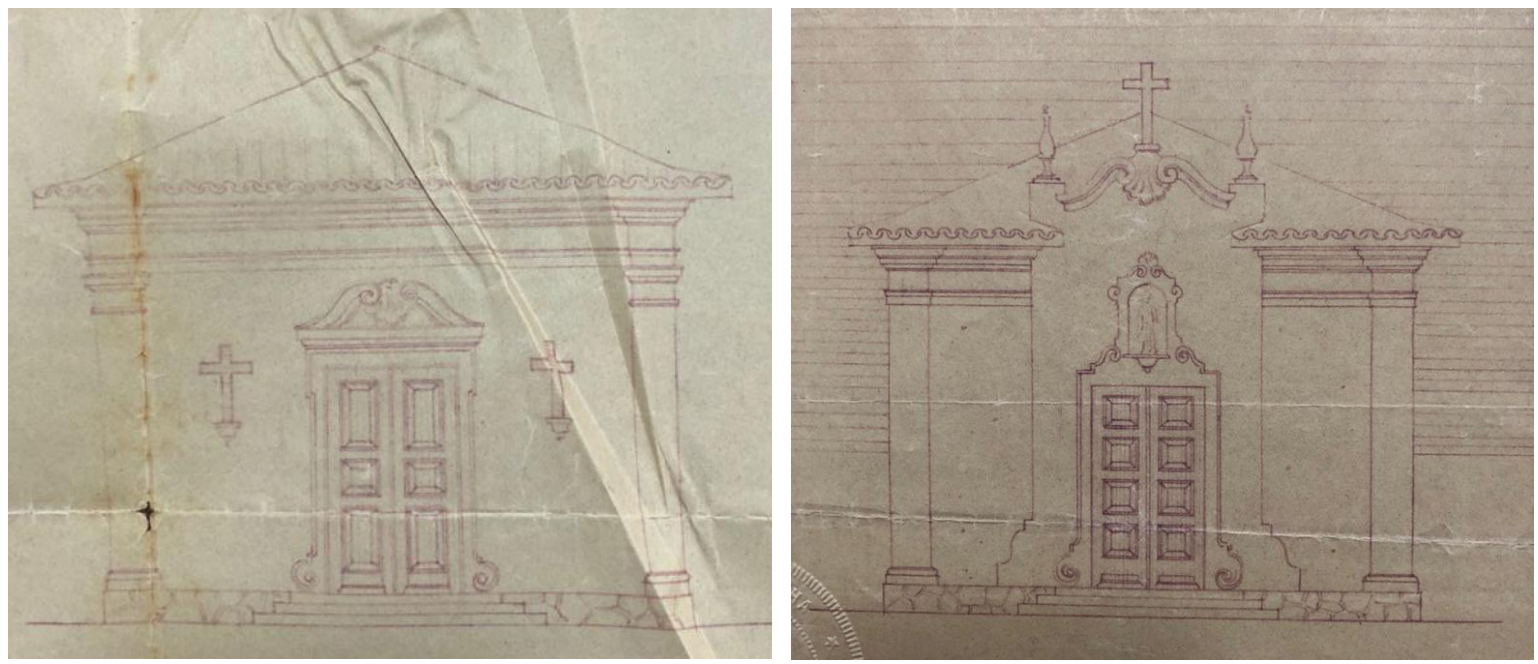

Figura 126 (esquerda): Fachada proposta como modelo "A". Figura 127 (direita): Fachada proposta como modelo "B".Fonte: Acervo da Cúria Metropolitana de Campinas.

28 Provisão para a construção de uma capela. (1943). Cúria Metropolitana de Campinas, Campinas, SP. 

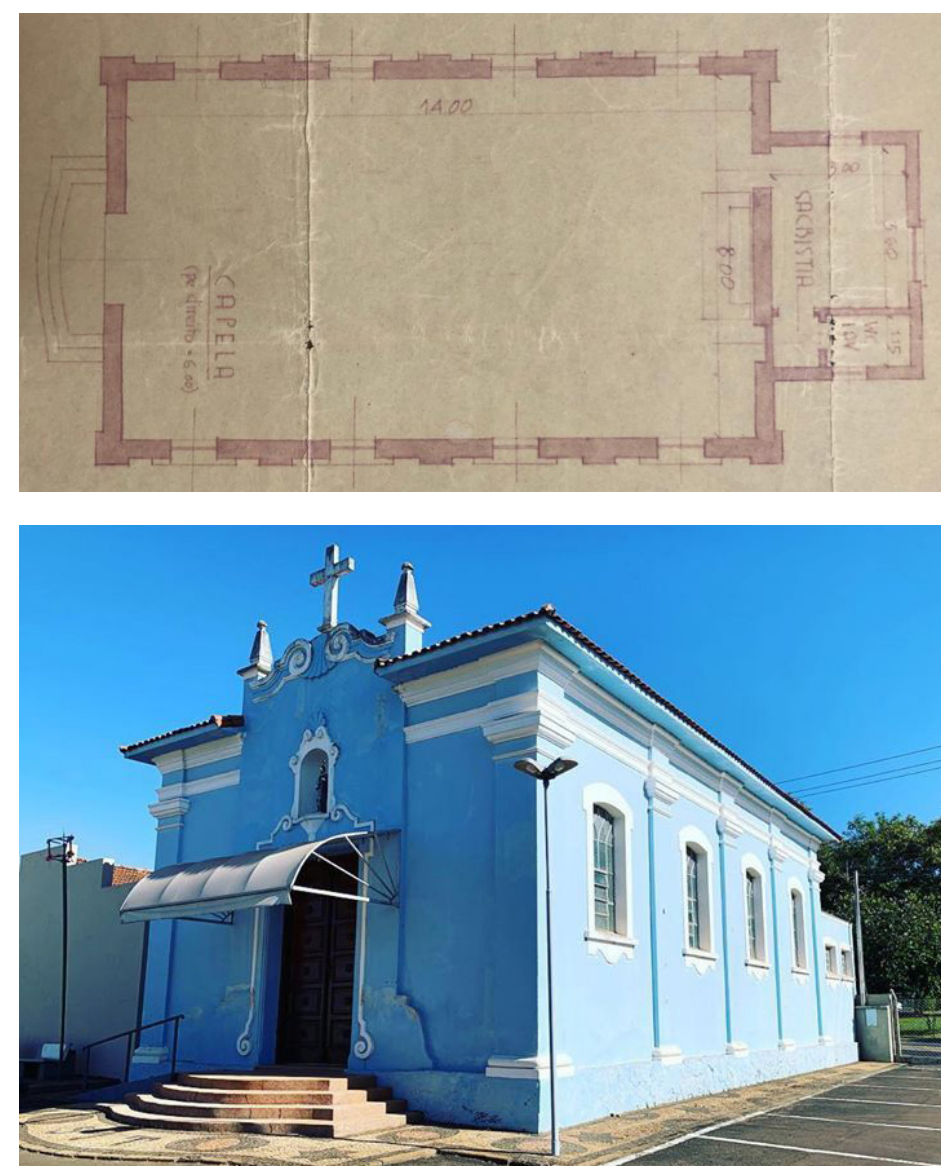

Figura 128: Planta da Capela São Judas Tadeu elaborada por Lix da Cunha. Fonte: Acervo da Cúria Metropolitana de Campinas.

Figura 129: Capela São Judas em 2018. Fonte: Acervo do autor.

\section{CAPELA FAZENDA SÃO JERÔNIMO}

\section{A Capela São Jerônimo foi construída em} 1927, na fazenda homônima. A maciça chegada de imigrantes italianos fez com que a capela tivesse uma vida dinâmica durantes várias décadas, até que, com o esvaziamento populacional da região rural, deixou de ter celebrações no início dos anos 2000. Atualmente a capela pertence à Usina São João.

Figura 130: Capela São Jerônimo.Fonte: Acervo do autor.

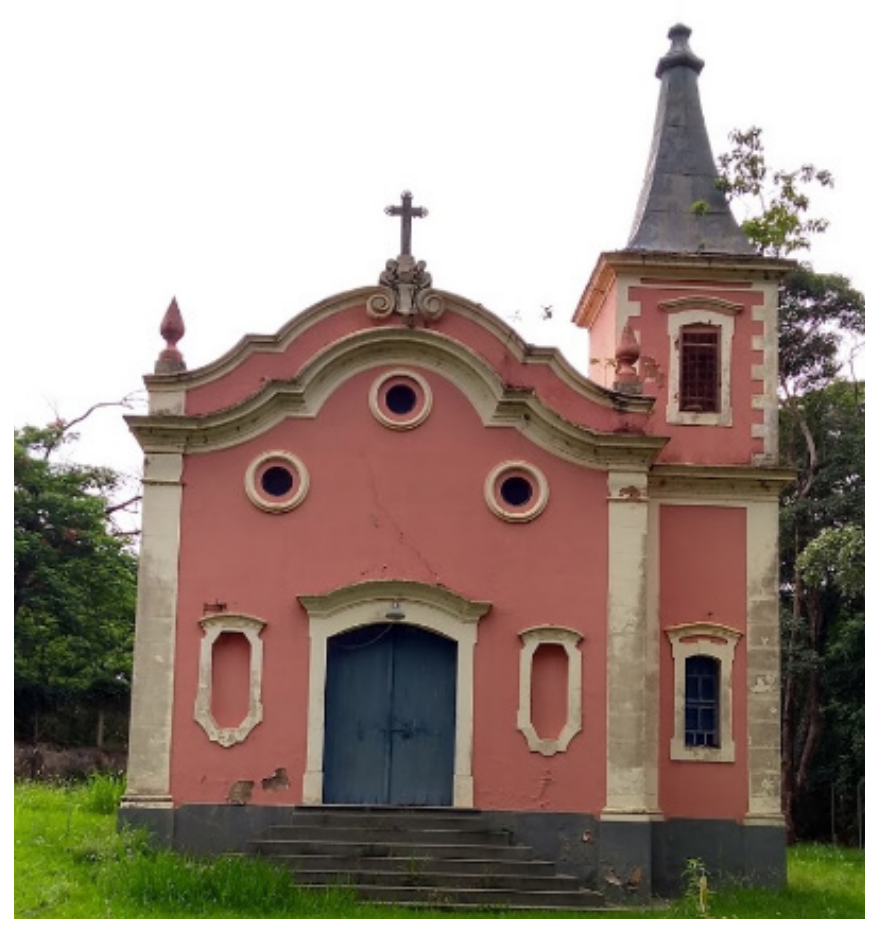




\section{IGREJA IMACULADA CONCEIÇÃO - LEME}

No início do século XX, o Cônego Joaquim Franco de Camargo ${ }^{29}$, que era pároco em Leme, deixou em testamento uma quantia para a ereção de uma capela em louvor à Imaculada Conceição na cidade. No entanto, sua vontade não foi realizada por dificuldades junto à cúpula eclesiástica, que não encontrava meios para fazer cumprir o testamento. Então, o amigo do sacerdote, Dr. José de Paula Leite, proprietário da Fazenda São Bento, decidiu empreender a construção da capela em suas terras, para realizar o desejo do padre. Segundo o jornal "O Município", o projeto da capela foi realizado "pelo Dr. Ricardo Severo, um dos mais respeitados arquitetos de São Paulo" e começou a ser construído em 1922 (O MUNICíPIO, 1958).
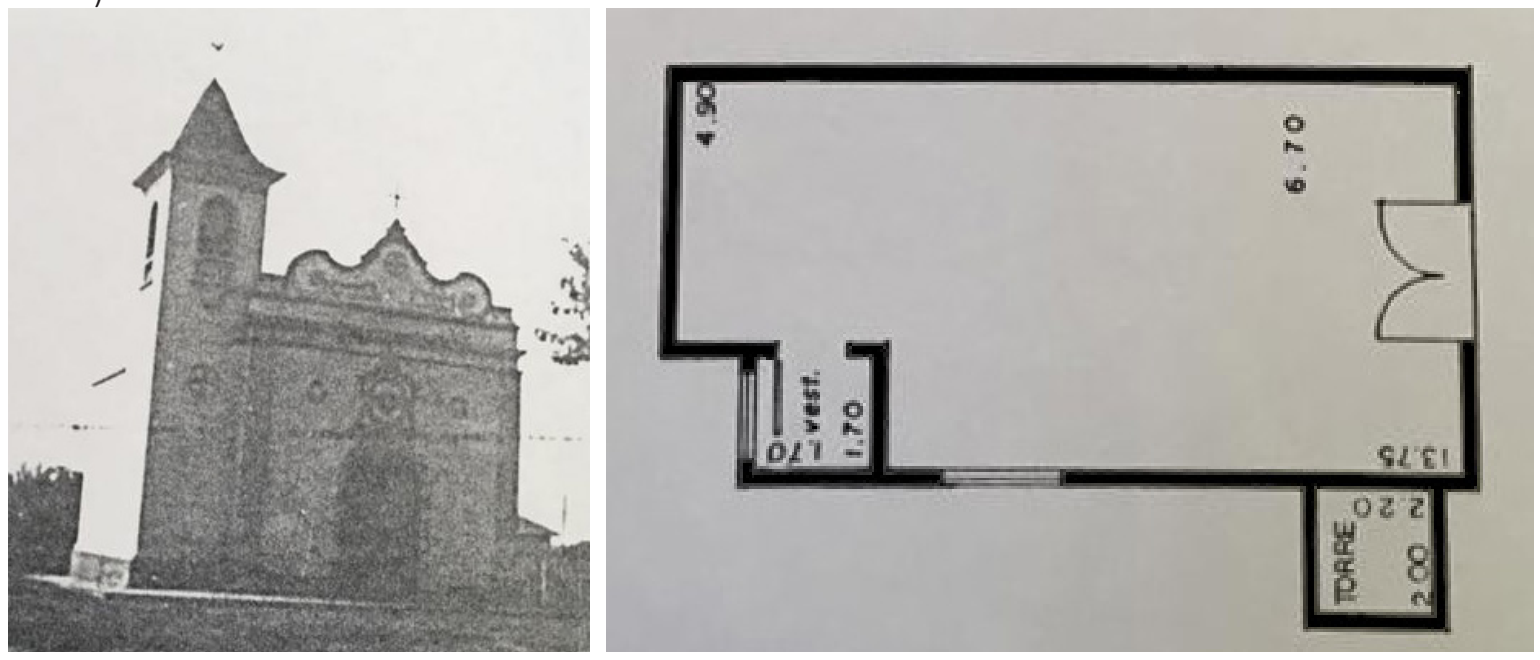

Figura 131 (esquerda): Capela Imaculada Conceição em 1923. Figura 132 (direita): Planta da capela original.

Fonte: Acervo da Paróquia Imaculada Conceição.

No ano de 1927, a capela passou a integrar a Paróquia São Manoel de Leme. Com o passar dos anos e o crescimento da cidade, a capela foi reformada em 1958 para comportar mais fiéis. Em 1961, a Diocese de Campinas criou a Paróquia da Imaculada Conceição, transformando então a capela em uma igreja matriz.

29 O Cônego Joaquim Franco de Camargo era proprietário da Fazenda Capitólio, cujas terras eram oriundas do desmembramento da Fazenda Montevidéu, que pertenceram a seu pai. Foi nas terras da dita fazenda, que a cidade de Araras nasceu. O sacerdote era ainda cunhado do Barão de Araras e do Barão de Ibitinga, além de ter sido pároco em Limeira antes de ser transferido para Leme. 


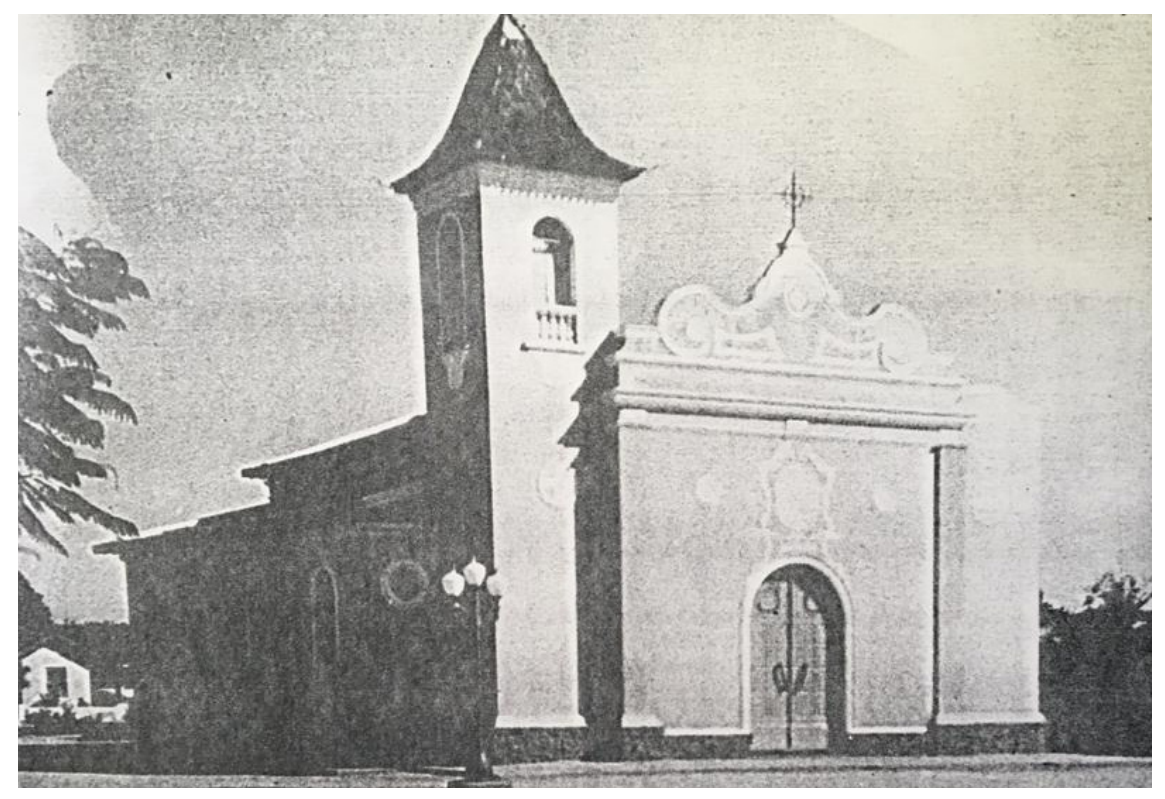

Figura 133: Capela Imaculada Conceição em 1958. Fonte: Acervo da Paróquia Imaculada Conceição.

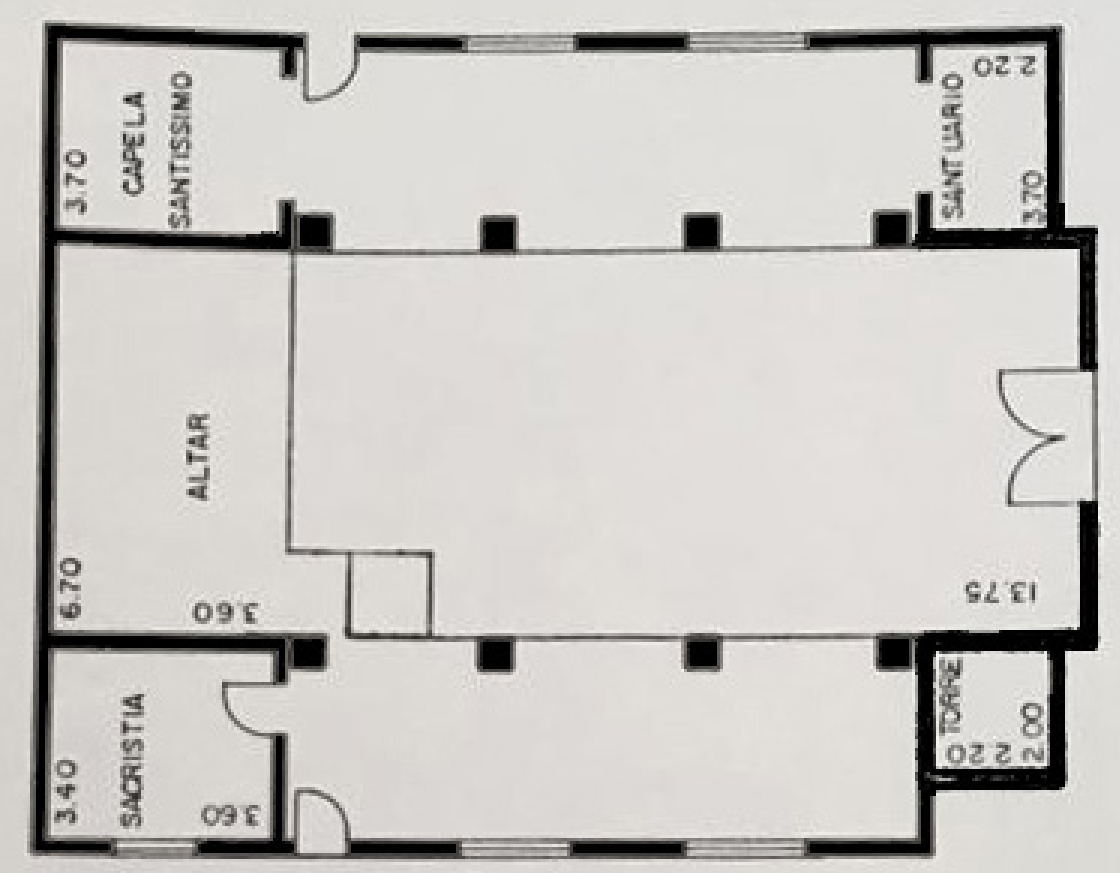

Figura 134: Planta da capela após a reforma. Fonte: Acervo da Paróquia Imaculada Conceição.

Na década de 90, devido ao tamanho da igreja e à necessidade de um templo maior para as atividades paroquiais, iniciou-se a demolição do antigo templo para construção de nova matriz. Porém, o Ministério Público embargou as obras, e iniciou um processo para o cancelamento da derrubada do edifício. Após anos de idas e vindas judiciais, foi autorizada a demolição do templo, que foi realizada em 04 de abril de 1994. Atualmente, existe uma nova igreja construída no local do antigo templo neocolonial de Ricardo Severo. 


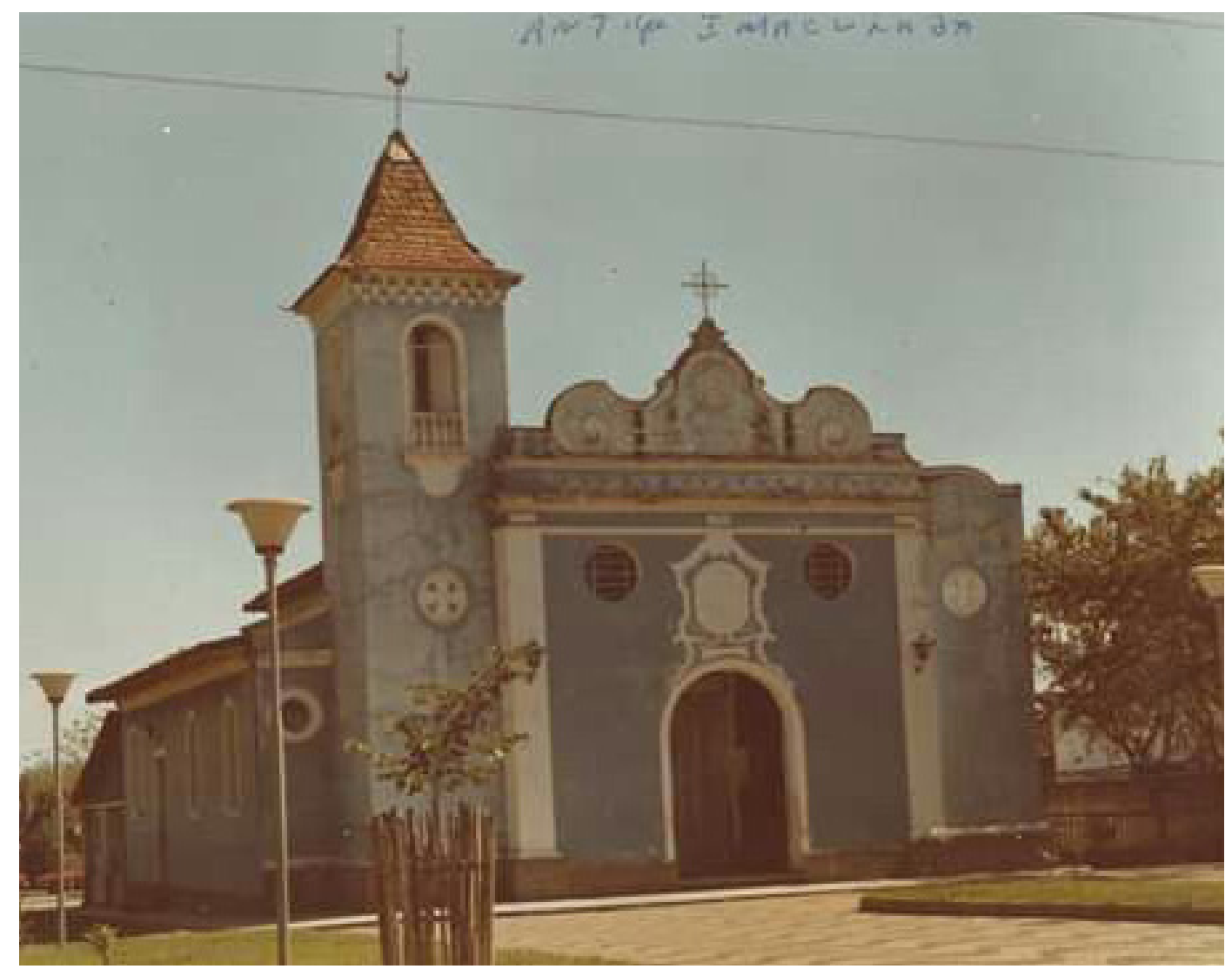

Figura 135: Igreja Matriz Imaculada Conceição em 1989, 5 anos antes de sua demolição. Fonte: Acervo da Paróquia Imaculada Conceição.

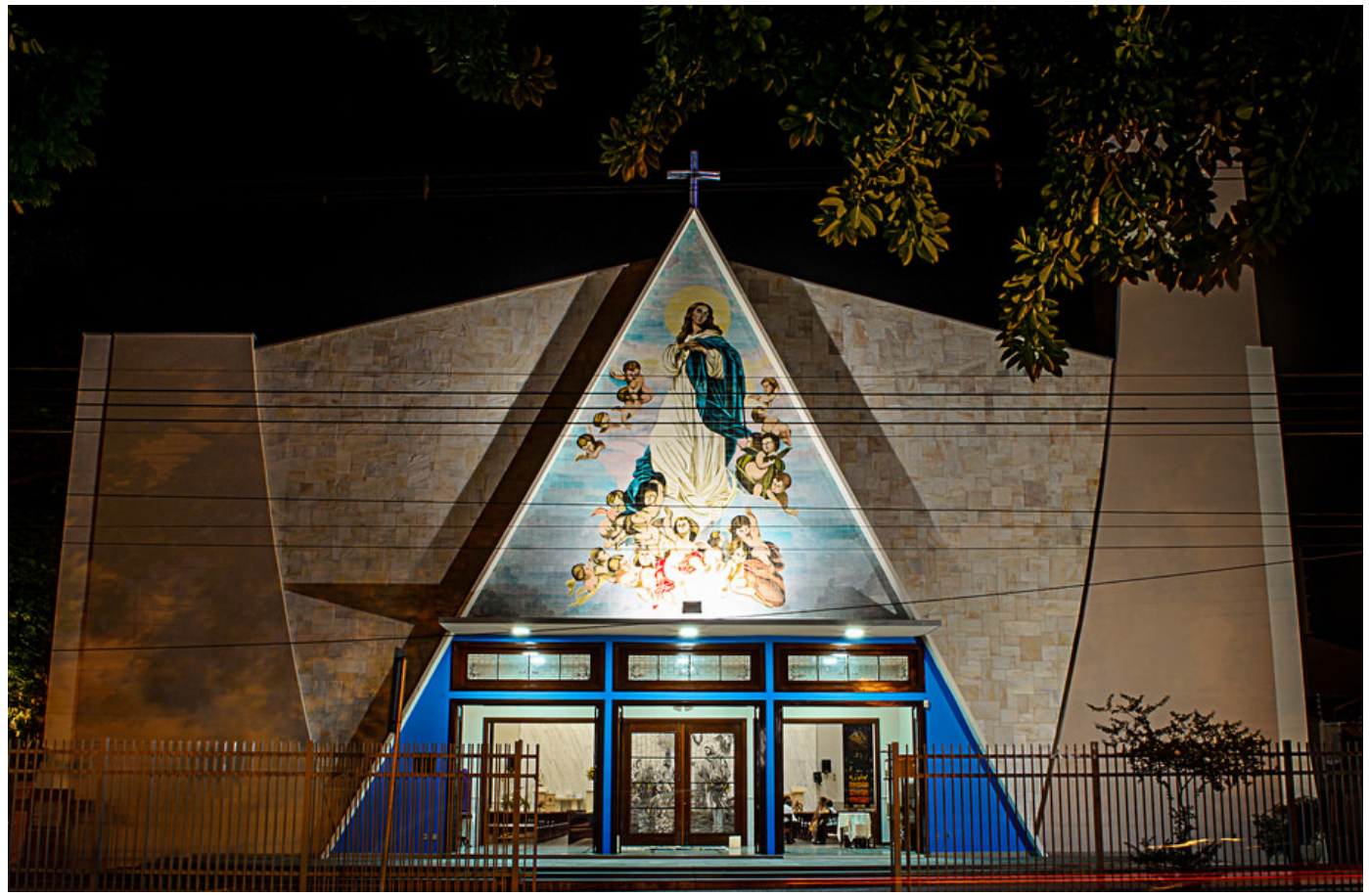

Figura 136: Nova Igreja Matriz Imaculada Conceição de Leme. Fonte: Diocese de Limeira. 



$$
\text { CONSIDERAÇÕES FINAIS }
$$




\section{CONSIDERAÇÕES FINAIS}

"Nunca houve uma época que não se sentisse "moderna" no sentido excêntico, e que não tivesse o sentimento de se encontrar à beira de um abismo. A consciência desesperadamente lúcida de estar em meio a uma crise decisiva é crônica na história da humanidade. Cada época se sente irremediavelmente nova. O "moderno", porém, é tão variado como variados aspectos de um mesmo caleidoscópio".

Walter Benjamin

Observar a cidade e seus edifícios é uma atividade cotidiana involuntária dos arquitetos e urbanistas. Analisar os conjuntos, as características, períodos de construção e até mesmo sinais que indicam o autor e o estilo empregado naquele edifício, ocorrem a todo momento quando passamos pelas cidades. Neste processo de leitura visual, sempre há algum edifício que nos desperta a atenção, seja pela sua especificidade ou peculiaridade, ou ainda algum outro fator que induza o desejo de conhecer mais sobre ele. Assim ocorreu com as igrejas neocoloniais, objetos deste estudo.

Quando criança, nas idas ao centro da cidade de Limeira na qual a visita à Catedral Nossa Senhora das Dores era imprescindível-, era impossível não notar o tamanho, os detalhes e a importância que era dada àquele edifício. Todas essas questões acabaram por suscitar o desejo de se conhecer mais sobre a igreja, sempre imponente no centro da cidade.

No entanto, com o passar do tempo e o aprofundamento dos conhecimentos e das pesquisas realizadas, algumas outras questões foram emergindo e mostrando-se relevantes para uma melhor compreensão dos fatos históricos, inclusive a necessidade de um olhar mais amplo para entender um acontecimento local. A partir dessa abordagem e da constatação da existência de um conjunto de igrejas dispersas pelo território da Diocese de Limeira, que apresentam uma trajetória construtiva em comum, configurou-se o objeto de estudo, como apontado na introdução deste trabalho.

Para entender como se deu a construção de tais edifícios e quais são as determinantes que impulsionaram tal empreitada, foi necessário realizar uma extensa busca nos arquivos históricos das paróquias e das cúrias, cujos resultados suscitaram a necessidade de entender o significado e a presença destas instituições em suas respectivas cidades. Por isso, no primeiro capítulo, tratamos da relação simbiótica da Igreja com a Coroa Portuguesa e com o Governo Imperial, cuja importância para o povoamento do território fica evidente a partir do estudo da gênese e do desenvolvimento dos núcleos urbanos aqui analisados. 
De fato, como evidenciado na pesquisa, a Igreja se tornou um instrumento de fomento e controle da ocupação da região, exercendo acima de tudo um papel político de organização territorial. Tal prerrogativa colaborou para que a Igreja fosse se estabelecendo e consolidando nos núcleos urbanos, sendo peça importante para o crescimento das urbes. Por sua vez, o edifício religioso que simbolizava a presença da Igreja - ermida, capela ou igreja matriz - ocupava uma posição central e era representativo da própria localidade, aspectos que justificam as inúmeras reconstruções e reformas pelas quais passaram esses símbolos eclesiásticos ao longo dos anos, como no caso da cidade de Limeira, criada nos primeiros anos do Governo Imperial.

Assim, o papel da Igreja, não apenas na gênese destes municípios, mas assumindo funções do Estado- como atividades de registro civil-, estabeleceu uma relação de dependência e ao mesmo tempo de identidade entre o poder eclesiástico e a vida da comunidade, consolidando costumes, práticas e tradições junto à população local. Até mesmo após a Proclamação da República e o advento do estado laico, a Igreja continuou a gozar de seus benefícios e de todo seu prestigio construído ao longo dos séculos. Porém, é interessante notar que o regime do Padroado também acarretou problemas para a Igreja, principalmente questões ligadas às terras patrimoniais, que se tornaram verdadeiros objetos de disputa e discórdia entre a Igreja e a municipalidade, como no caso de Limeira, Santa Cruz da Conceição e Porto Ferreira.

Analisando o processo histórico de formação das cidades que compõem a Diocese de Limeira, fica claro que a Igreja foi determinante para sua consolidação, pois, apesar de todas as nuances e variações que cada local apresentou, em todas a instituição esteve presente, inclusive nas cidades da região do Funil, que surgiram no século XX. Sob esta ótica, é interessante notar que a tardia divisão territorial que configurou a Diocese de Limeira, no último quartel do século XX, segue uma lógica religiosa e não geográfica ou política. De fato, sua criação se deu a partir do desmembramento de uma porção territorial pertencente à Arquidiocese de Campinas, cuja área extensa e diversificada, e rápido crescimento populacional, dificultava sua administração por parte do bispo diocesano. Os mapas que compõem o primeiro capitulo propõem uma análise gráfica deste território, onde é possível notar a forma com que as cidades foram se fixando no território ao longo do tempo e quais foram as determinantes para isso, como a presença dos rios, a chegada das ferrovias, industrias e rodovias, além das questões sociais que colaboraram para o crescimento local.

Assim, o presente trabalho evidencia que, apesar das igrejas apresentarem processos de gênese e crescimento diversos umas das outras, e de estarem inseridas em ciclos econômicos diferentes, em determinando momento, passaram a compartilhar questões em comum, principalmente no século XX, com as reformas e reconstruções de seus templos. 
No que se refere à reestruturação da Igreja no século XX, é notável que o desenvolvimento das cidades, o crescimento populacional e a chegada maciça de imigrantes colaboraram para sua consolidação e hegemonia. A atuação da Igreja na sociedade, mesmo com a separação do Estado, se consolidou cada vez mais e a própria instituição buscou formas de melhor se adequar à nova realidade. A reconstrução dos edifícios religiosos se tornou oportuna neste sentido, pois, além de renovar a imagem do templo, símbolo da Igreja naquele local, permitia torná-lo condizente com os novos padrões de modernidade vigentes.

Como visto, ao longo da primeira metade do século, quase todas as cidades que compõem a Diocese de Limeira passaram por um processo semelhante de atualização de suas igrejas matrizes. Nos primeiros anos do século $X X$, as pequenas capelas construídas no último quartel do século XIX foram reformadas e ampliadas, e as igrejas mais antigas, que já tinham sido reconstruídas naquele mesmo século, foram reformadas conforme os padrões arquitetônicos do período, geralmente vinculados ao ecletismo.

Com o passar dos anos e o aparecimento de novas vertentes arquitetônicas, as reformas e reconstruções passaram a ser realizadas numa gama de novas possibilidades, dentre elas o Neocolonial, adotado nas paróquias Nossa Senhora das Dores de Limeira, Nossa Senhora da Conceição de Santa Cruz da Conceição, São Sebastião de Porto Ferreira, Jesus Crucificado de Iracemápolis e Santa Gertrudes de Cosmópolis. Esse conjunto de edifícios religiosos reconstruídos neste estilo em meados do século XX revela uma inesperada vitalidade do Neocolonial, que contradiz qrande parte dos estudos sobre o tema no âmbito da historiografia da arquitetura brasileira. Apesar de ser uma manifestação oriunda das primeiras décadas do século XX, o Neocolonial foi empregado até meados do século nas tipologias religiosas, como no caso das igrejas apresentadas, onde o neocolonial foi utilizado como símbolo de modernidade e progresso.

No que se refere às igrejas de estudo, nota-se uma variação muito grande dentro do próprio estilo. No caso de Santa Cruz da Conceição, trata-se de uma reforma: o projeto não realiza nenhuma alteração estrutural no antigo edifício, apenas lhe confere feições neocoloniais. Neste caso, nota-se que a transformação da igreja, que possuía uma tipologia muito comum encontrada da região, de pequeno porte e torre central, exprime uma busca de diferenciação das igrejas mais simples, com a inserção de elementos arquitetônicos ligados ao barroco mineiro.

No projeto de Benedito Calixto Neto para a Igreja São Sebastião, em Porto Ferreira, há um predomínio de características luso-brasileiras, com a inserção de elementos próprios da arquitetura religiosa colonial brasileira. É válido destacar que o próprio arquiteto denomina o projeto como sendo colonial modernizado, ou seja, pressupondo uma atualização de 
determinados ornamentos e espaços, e, principalmente, uma renovação estrutural e espacial. Além disso, no projeto de Calixto, a decoração interna foi repensada com novas formas de representação do espaço sagrado, numa clara demonstração de sua atenção às vanguardas da ornamentação religiosa da época, que acarretou numa fusão do tradicional com o inovador, na combinação da arquitetura neocolonial com o grande painel de Antônio Maria Nardi.

O mesmo repertório luso-brasileiro foi adotado por Joaquim Bezerra da Silva em Iracemápolis, cuja matriz, rapidamente construída com a colaboração constante da Usina Iracema, é um belo exemplar deste estilo. O apoio da iniciativa privada, neste caso, foi fundamental para que as obras mantivessem um ritmo acelerado e fossem concluídas num curto espaço de tempo. O mesmo não ocorreu em Cosmópolis, onde a Usina Ester, que havia sido até então a grande mantenedora da paróquia, não manteve suas constantes colaborações, fazendo com que as obras se arrastassem ao longo dos anos e que fosse necessário até mesmo o auxílio de órgãos públicos para sua conclusão.

Ao contrário das igrejas de Porto Ferreira e Iracemápolis, os projetos de Mario Penteado para as matrizes Cosmópolis e Limeira assumem características do estilo missões, ou seja, seguem a linha neocolonial hispânica, que se baseia na arquitetura oriunda das missões religiosas espanholas construídas nos Estados Unidos da América, principalmente na região da Califórnia. No caso da Igreja Santa Gertrudes de Cosmópolis, o arquiteto utiliza o estilo missões de modo mais puro, enquanto na Igreja Nossa Senhora das Dores de Limeira, propõe uma fusão de elementos oriundos das duas vertentes. Não há registros dos processos de concepção dos projetos e dos motivos que levavam os arquitetos a adotar esta ou aquela vertente do neocolonial, porém, é válido destacar que, como aponta Atique (2010), houve uma grande circulação de materiais oriundos dos Estados Unidos nas escolas de arquitetura difundindo este tipo de arquitetura no solo brasileiro.

Além disso, é notável a semelhança de tais projetos com a Igreja Nossa Senhora do Brasil, localizada no bairro da Urca, no Rio de Janeiro, construída em 1934 e de autoria do engenheiro arquiteto Frederico Faro Filho, formado pela Escola Nacional de Belas Artes. Mario Penteado, além de ter morado no Rio de Janeiro, também foi aluno da ENBA. 


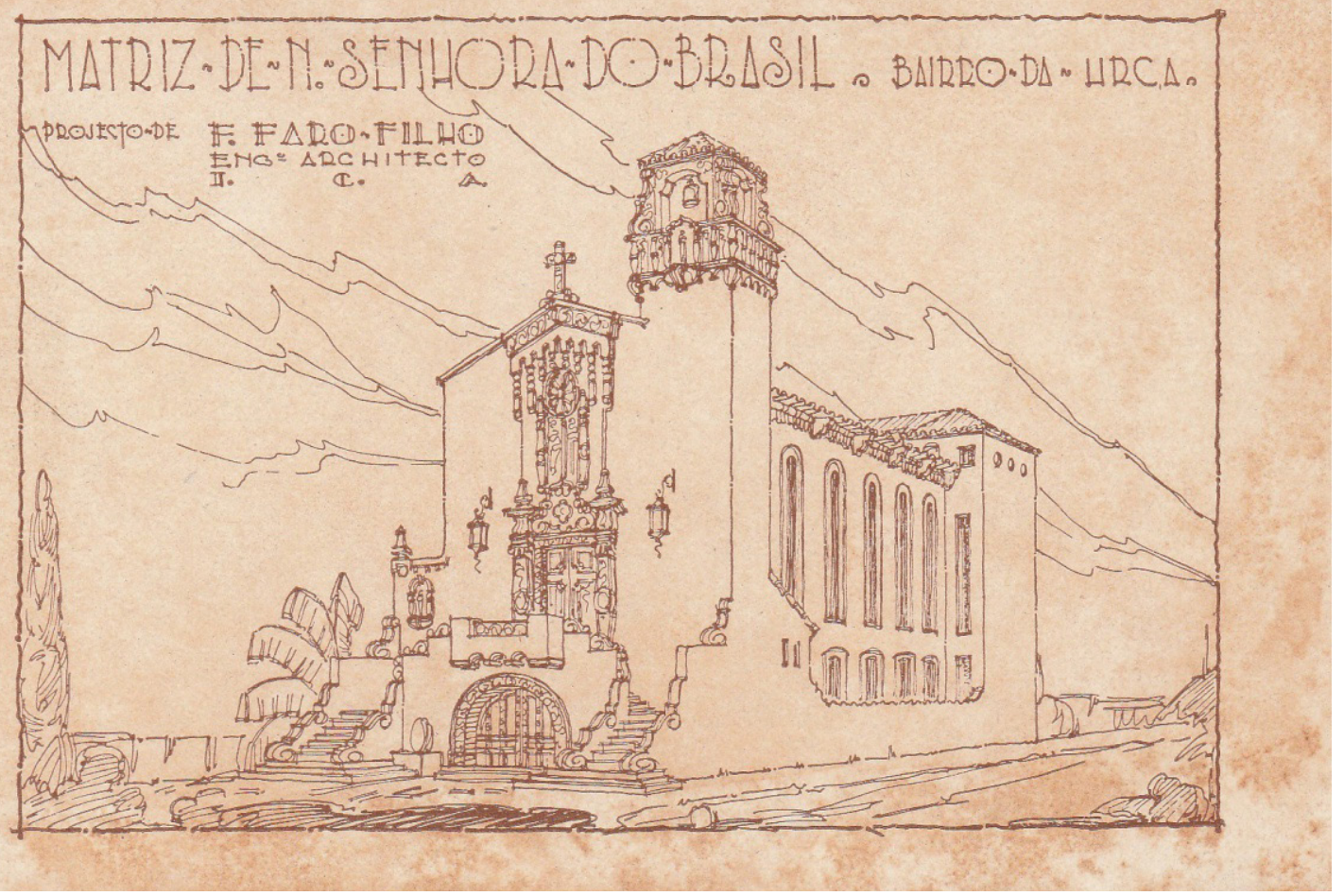

Figura 137: Projeto da Igreja Nossa Senhora do Brasil do Rio de Janeiro de autoria de Frederico Faro Filho. Notase a semelhança da fachada, da torre e demais ornamentos da portada com a igreja de Cosmópolis. Alguns ornamentos foram ainda replicados na igreja de Limeira. Fonte: Igreja Nossa Senhora do Brasil.

No que se refere ao conjunto de templos em questão, as pesquisas realizadas até o momento deixam claro o apreço da Igreja pelo estilo neocolonial, pois, como mostrado no decorrer do trabalho, inúmeros são as menções encontradas nos documentos consultados exaltando a qualidade desta arquitetura. No entanto, ainda não ficaram claros os motivos que levaram os arquitetos ou a Igreja a escolher tal estilo para a reconstrução de seus templos, aspecto que carece de maior aprofundamento, mas é possível elencar alguns fatos que podem ter induzido tal escolha.

Além da formação, como já apontado no caso de Mario Penteado, o fato de várias igrejas neocoloniais da cidade de São Paulo terem sido concluídas em meados do século XX pode ter contribuído para tal escolha. O caso da Igreja Nossa Senhora do Brasil, no bairro do Jardim América, em São Paulo, é bastante significativo, pois se trata de uma igreja localizada em área nobre da cidade, que logo se destacou por ser frequentada pelas elites paulistanas. A construção do edifício, projetado pelo engenheiro-arquiteto Bruno Simões Magro, iniciouse em 1942 e prolongou-se durante 14 anos, sendo concluída somente em 1956, período análogo ao da construção das matrizes neocoloniais abordadas neste estudo. É valido destacar, também, que outras igrejas neocoloniais haviam sido concluídas recentemente na capital paulistana, como: a Igreja São Judas Tadeu em 1941, Igreja de Nossa Senhora dos Remédios em 1944 e Convento de Santa Tereza em 1948. Além disso, em se tratando 
de influências construtivas, é oportuno apontar que a finalização da Catedral da Sé, em 1954, pode ter influído no processo de decisão pela renovação da igreja matriz nas cidades estudadas. Apesar de ter sido construída no estilo neogótico, a substituição do antigo edifício por um novo representava uma renovação urbana e social ansiada pelas cidades.

Deste modo, a opção pelo Neocolonial na reconstrução das cinco matrizes destacadas neste estudo revela uma longevidade do estilo absolutamente inusitada, à luz da maior parte dos estudos sobre o tema, apontando a necessidade de aprofundamento dos casos em questão. Tais edifícios configuram-se como elementos de importante significado e identidade para as cidades onde estão inseridos e para a histografia da arquitetura, pois, além de seu papel simbólico, podem contribuir para uma compreensão mais aprofundada da produção arquitetônica no interior do estado de São Paulo.

Neste sentido, é importante pontuar questões referentes à preservação destes edifícios. Como já evidenciado ao longo do estudo, com exceção das igrejas do período colonial, a arquitetura religiosa em geral não foi contemplada com ações de preservação, principalmente aquelas construídas entre a última metade do século XIX e primeira metade do século XX. As frequentes alterações realizadas nas igrejas objeto deste estudo ao longo dos anos, e até mesmo as demolições que resultaram nas reconstruções aqui apresentadas, deixam isso claro.

Analisando os fatores que colaboraram para alterações na arquitetura religiosa em meados do século XX, além dos anseios de modernidade e sucessivas reformas e ampliações desejadas pelos padres e pela comunidade, a promulgação dos documentos finais do Concilio Ecumênico Vaticano II, em 1965, propondo mudanças drásticas no regimento da Igreja, reverberou fortemente no espaço arquitetônico religioso.

Neste período, as igrejas passaram por um processo de mudança e atualização para suprir as demandas da nova liturgia. Inúmeras foram as alterações realizadas nos ritos dos sacramentos e da santa missa. No espaço sagrado, a missa, que até então era celebrada de costas (versus Deum), passou a ser presidida em um altar central, de frente para o povo (versus populorum). As concelebrações ${ }^{1}$ passaram a ser permitidas, a grade de comunhão deixou de existir, e as leituras, que até então eram todas feitas pelo padre, passaram a ser proferidas por fiéis leigos da assembleia. Há, ainda, outras alterações que foram realizadas e que eram necessárias para acomodar o novo modo de celebração dentro das igrejas. As

$1 \quad$ Até aquele momento, a missa era presidida somente por um padre de cada vez, por isso é comum encontrar vários altares nas igrejas mais antigas, para possibilitar que dois padres celebrassem ao mesmo tempo, sendo um cada altar. Com as mudanças propostas, dois padres passaram a celebrar juntos o sacrifício da missa, em um mesmo altar, surgindo desta forma a concelebração. 
instruções para tais reformulações, de uma maneira geral, determinavam que as igrejas antigas deveriam repensar suas estruturas e que as novas fossem projetadas de acordo com a nova liturgia.

Este fato fez com que as igrejas neocoloniais em questão - tanto aquelas cuja construção estava em andamento, como aquelas recém-finalizadas -, fizessem alterações em seus projetos, causando transtornos e incongruências em sua disposição interna. Por estarem com as paredes já levantadas e totalmente cobertas, tanto os padres, quanto os arquitetos, não tinham noção do que fazer com os espaços que ficaram sem uso e que já estavam construídos. Mesmo realizadas às pressas, as alterações no layout e na disposição do mobiliário sacro foram mais facilmente solucionadas. . O maior prejuízo, no entanto, se deu na ornamentação, justamente a etapa de acabamento pela qual passavam então muitos dos templos, que ficou severamente comprometida.

Na Arquidiocese de Campinas, à qual as paróquias aqui apresentadas pertenciam, o bispo diocesano emitiu um parecer instruindo os padres a realizarem adaptações em suas igrejas. Diz o documento:

1) Prossigam os esforços de atualização da reforma e renovação litúrgica da comunidade paroquial. Neste sentido, devidamente autorizados pelo Exmo. Sr. Arcebispo, determinamos que seja, o mais brevemente possível, adaptada a igreja paroquia às novas exigências litúrgicas do Concílio Ecumênico, a saber:

a) A adaptação do altar mor para a celebração versus populorum.

b) A reforma dos púlpitos facilitando a visibilidade do altar por toda a assembleia.

c) O fechamento do átrio de entrada da igreja com portas dentro do estilo, sem prejuízo do que já está construído (TOMBO I. SS. p.05).

Analisando algumas alterações feitas nas igrejas estudadas, é possível identificar ações realizadas em consonância com essas orientações, como no caso da Matriz de Limeira, onde a galilé original do projeto foi fechada com portas de madeira, fazendo com que a igreja acabasse ficando com dois átrios. As demais alterações foram executadas de maneira emergencial, tendo sido finalizadas no decorrer dos anos.

O problema principal quanto à preservação destes bens, ocasionado por estas mudanças e vivenciado na atualidade, não está diretamente relacionado à transformação dos espaços e elementos em novos arranjos, mas sim nos espaços que ficaram inconclusos e sem uso, como por exemplo os antigos recuos construídos para os altares laterais e os vãos destinados à instalação dos confessionários, que se tornaram espaços para inserções e completamentos contemporâneos, como no caso de Limeira e Cosmópolis.

Os espaços sem uso e a ausência de finalização na ornamentação do conjunto têm 
potencializado alterações, reconstruções e refazimentos na contemporaneidade, que em boa parte dos casos, têm desfigurado e alterado a coerência arquitetônica destes bens. Como já apontado anteriormente, as igrejas de Limeira, Cosmópolis e Iracemápolis foram as mais alteradas, sendo que, em alguns dos casos, como no de Limeira, as alterações de monta vão além de inserção de elementos contemporâneos no espaço celebrativo, chegando a concluir partes inacabadas segundo o projeto original e criando novas proposições para outros espaços.

Além disso, cabe destacar também, como hipóteses ainda a serem verificadas, pois demandam mais estudos aprofundados, que o período de construção destas igrejas favoreceu ainda outros agravantes que potencializam a desfiguração de tais edifícios. O primeiro problema a ser elencado é a própria morosidade do processo construtivo, que durou décadas em alguns casos, acarretando comprometimento das estruturas antes da sua finalização e acabamento. Tais problemas podem ter acontecido devido a instabilidades econômicas e ao encarecimento de mão de obra qualificada, ocasionado pelo desaparecimento de artesãos e profissionais liberais que realizavam os serviços de decoração, arremate e ornamentação. Com o surgimento das construtoras e o desapego crescente quanto à ornamentação arquitetônica, foi se tornando cada vez mais difícil finalizar os projetos neocoloniais, cuja essência estava na utilização de elementos ornamentais para a composição de uma linguagem colonial.

Deste modo, é necessária uma maior atenção, por parte dos órgãos públicos de preservação, quanto às alterações pelas quais têm passado estes bens. Apesar de todo o prestígio conferido ao Neocolonial na construção dessas igrejas na metade do século XX, nenhuma política de preservação foi direcionada a esses bens até então, apenas a Catedral de Limeira é marcada como edifício de interesse histórico para a cidade pelo CONDEPHALI².

Além das questões arquitetônicas, estes edifícios estão vinculados a uma instituição muito mais antiga do que sua própria sede construída, e que como mostrado no decorrer do trabalho, são importantes símbolos para o local onde estão inseridos, por sua profunda imbricação na gênese e no desenvolvimento urbano local.

No caso das cidades estudadas, as igrejas neocoloniais representam o pensamento de um povo que desejava erigir não apenas um símbolo de fé, mas também de progresso e desenvolvimento para sua cidade, cuja materialização se dava no edifício da igreja matriz. Os processos históricos construtivos, os agentes, as campanhas empreendidas pelas comissões de obras e o engajamento da comunidade na construção destas igrejas, são fatores que evidenciam a relevância destes edifícios, cuja presença se tornou um marco nas cidades

2 Conselho de Defesa do Patrimônio Histórico e Arquitetônico de Limeira. 
onde estão inseridos, um elemento identitário da paisagem urbana.

Deste modo, pensar estes edifícios na chave da preservação é extremamente necessário, pois as alterações pelas quais os mesmos têm passado, representam um risco à sua integridade. O poder público e as paróquias deveriam atuar conjuntamente em ações que viabilizem a manutenção e a conservação de tais obras, tanto por aspectos sociais, ligados à memória coletiva da população, quanto por questões arquitetônicas e urbanas, contribuindo para o entendimento e conhecimento da produção da arquitetura paulista no século XX. 

REFERÊECIAS 


\section{REFERÊNCIAS}

ACERVO COSMOPOLENSE. Padroeira de Cosmópolis. (https://acervocosmopolense.blogspot. com/2013/11/padroeira-de-cosmopolis.html. Acessado em: 20/02/2019)

ARCHDAILY. Clássicos da arquitetura - Igreja da Pampulha. (https://www.archdaily.com.br/ br/01-83469/classicos-da-arquitetura-igreja-da-pampulha-slash-oscar-niemeyer. Acessado em: 11/01/2021)

ARQUIDIOCESEDECAMPINAS.CriaçãodaDiocesedeCampinas.(https://arquidiocesecampinas. com/wp-ontent/uploads/2017/03/Prov\%C3\%ADncia.jpg. Acessado em: 03/12/2020).

ALMEIDA, Rosângela Doin de. Atlas Municipal Escolar de Limeira - Geográfico, Histórico e Ambiental. Educação: Teoria e Prática, v. 7, n. 12/13, 1999.

AMARAL, Aracy A. (Coord.). Arquitectura neocolonial: América Latina, Caribe, Estados Unidos. São Paulo: Memorial; Fundo de Cultural Econômica, 1994.

ARNONI, Renan Fernando Freitas. História Social e Econômica de Porto Ferreira (1880-1970). Porto Ferreira, SP - Gráfica Editora São Paulo, 2020.

A construção da Igreja Matriz de São Sebastião. 1a Parte. In. Jornal do Porto (07/08/2015).

AROUCHE, Júlio de. A Igreja Nossa Senhora da Boa Morte, na cidade de Limeira, Provincia de São Paulo, In. Archivo Pitoresco, Semanario ilustrado.9o anno. V.9, Lisboa: Editores Castro Irmãos e Cạ, 1866, p. 207-8.

A SEMENTE. Revista comemorativa dos 100 anos da Paróquia Santa Gertrudes de Cosmópolis. Paróquia Santa Gertrudes - Cosmópolis - setembro de 2015.

ATIQUE, Fernando. Arquitetando "A boa vizinhaça": arquitetura, cidade e cultura nas relações Brasil-Estados Unidos - 1876-1945. Pontes Editora, Fapesp, São Paulo, 2010. 
Urdiduras continentais no debate acerca do Mission Style. Notas sobre o panamericanismo na arquitetura neocolonial. Revista Eletrônica da ANPHLAC. São Paulo, ANPHLAC, n.10, 2011. (http://revistas.fflch.usp.br/anphlac/article/view/1293/1160. Acessado em: 05/09/2019).

. Memória moderna. A trajetória do Edifício Esther. São Paulo, Fapesp, RiMa, 2004. . Memória de um Projeto Moderno: a idealização e a trajetória do Edifício Esther. 2002. Dissertação de Mestrado. Instituto de Arquitetura e Urbanismo da Universidade de São Paulo. São Carlos - SP.

AZEVEDO, Ricardo Marques de. Las ideas de Ricardo Severo y la relacion com el academicismo. In: AMARAL, Aracy (org.) Arquitectura neocolonial: América Latina, Caribe, Estados Unidos. 1a. ed. São Paulo: Memorial Fondo de Cultura Económica, 1994, pp. 249-258.

BALDIN, Adriane. Tijolo sobre tijolo: os alemães que construíram São Paulo. Curitiba, Editora Prismas, 2014.

BELLI, Sônia. Descalvado de 1809 - 1996. Porto Ferreira, SP - Gráfica Editora São Paulo,1997. BERNADI, Tiago Costa. A arquitetura Neocolonial e as "sabias lições" de José Mariano Filho. Monografia de conclusão de curso. Universidade Federal Rural do Rio de Janeiro - Instituto Multidisciplinar. Nova Iguaçu, 2014.

BERTO, João Paulo. História, gestão e preservação: os bens culturais eclesiásticos na diocese de Limeira-SP. Tese (doutorado)- Universidade Estadual de Campinas, Instituto de Filosofia e Ciências Humanas, Campinas, SP, 2018.

BIBLIOTECA NACIONAL. Coleção Morgado de Mateus. (http://www.bn.br/bndigital/pesquisa. html. Acessado: 05/01/2021).

BORGES, M. E. A história das marmorarias italianas no estado de São Paulo impressa em anúncios de jornais (1890-1930). Revista da Universidade Federal de Minas Gerais, Belo Horizonte, v. 25, n. 1 e 2, p. 144-157, 2018.

BORSOI, Diogo Fonseca. Nos Traços do Cotidiano: Cunha entre as Vilas de Serra Acima e os Portos da Marinha (1776 - 1817). Dissertação de Mestrado em Urbanismo da Faculdade de Urbanismo de São Paulo - FAU USP, São Paulo, 2013.

BRITO, Jolumá. História da cidade de Campinas. Campinas, SP: [s.n.], 1967. Nv ISBN (Enc.). . História da cidade de Paulínia. São Paulo. 1972.

BRUAND, Yves. Arquitetura contemporânea no Brasil. São Paulo: Perspectiva. 1981. 
BUENO, Beatriz Piccolotto Siqueira. Dilatação dos confins: caminhos, vilas e cidades na formação da Capitania de São Paulo (1532-1822). Anais do Museu Paulista, Dez 2009, vol.17, no.2, p.251-294. ISSN 0101-4714

BUSCH, Reynaldo Kuntz. História de Limeira. 3 ed. Limeira: Sociedade Pró-Memória, 2007.

CAMPINAS VIRTUAL. Catedral e praça Dom Nery. (https://www.campinasvirtual.com.br/ galeria/campinas-1/catedral-e-Praca-Dom-Nery-1932.jpg. Acessado em: 03/12/2020).

CAMPOS, Paulo de Tarso. Provimento da Visita Pastoral de 1942. Cúria Metropolitana de Campinas, Campinas, SP.

CAPRI, Roberto. (1928). São Paulo. São Paulo: s.i.

CARITÁ, Wilson José. A Igreja Nossa Senhora das Dores de Limeira. Limeira: Sociedade Pró Memoria de Limeira, 1998.

(1998a ). Breve histórico da Confraria de Nossa Senhora da Boa Morte de Limeira. Limeira: Sociedade Pró Memoria de Limeira

CARVALHO, Beatriz Fernanda de Carvalho. O Santuário São Sebastião: arquitetura sacra neocolonial em Porto Ferreira - SP. Relatório de Iniciação Cientifica - FAPESP - UNESP Bauru - agosto de 2018.

CHARTIER, Roger. A história cultural: entre práticas e representações. Lisboa: DIFEL, 1990.

COELHO, M. B. L. Aspectos Históricos de Porto Ferreira. 02 Volumes. Porto Ferreira: Ed. Gráfica São Paulo, 2012.

ARNONI, Renan F. F. Aspectos Históricos de Porto Ferreira. Vol.II. Porto Ferreira: Editora Gráfica São Paulo, 2013.

CORREA, João Batista. Santa Cruz, onde a ferrovia não passou. Santa Cruz da Conceição. 2005.

D'ALAMBERT, Clara Correia. Manifestações da arquitetura residencial paulista entre as grandes guerras. Tese de Doutorado em estruturas ambientais urbana. Faculdade de Arquitetura e Urbanismo, Universidade de São Paulo, São Paulo, 2004.

DA SILVA, Flávio. História e estórias de Porto Ferreira. Porto Ferreira, Editora Gráfica de São Paulo, 2005.

DERNTL, Maria Fernanda. Método e Arte: criação urbana e organização territorial na capitania de São Paulo 1765-1811. Tese de Doutorado, FAU USP, São Paulo, 2010. 
DIOCESE DE LIMEIRA. Relatório para a criação da Diocese. 1975. Campinas.

DOMINGUES NETO, Hilário. Navegando o Rio Mogi Guaçu: a agroexportação cafeeira no Oeste Paulista e a formação de um mercado interno regional (1883-1903). São Paulo, Editora UNESP, 2009.

DVORAK, Catecismo para a preservação de Monumentos. Cotia - SP. Atêlie Editorial. 2008. ESTAÇÕES FERROVIÁRIAS. Estações Ferroviárias do Brasil. (http://www.estacoesferroviarias. com.br/l/fotos/limeira1900-AB.jpg. Acessado em: 05/01/2021)

Estações Ferroviárias do Brasil. (http://www.estacoesferroviarias.com.br/c/mapas/ cosmopolis.jpg. Acessado em: 05/01/2021).

ESTADO DE SÃO PAULO, Departamento de Estatística. Quadro demonstrativo do desmembramento dos municípios. São Paulo, 6a Edição. 1954. p.159.

FERROVIAS DO BRASIL. Ferrovias do Brasil 1970. (http://vfco.brazilia.jor.br/ferrovias/ mapas/1970ciaPaulista.shtml. Acessado em: 05/02/2021).

FÁVERO, Edison. HELFLINGER JÚNIOR, José Eduardo. Retratos de Engenheiro Coelho. Limeira, SP: Unigráfica, 2011.

FERRARI, Sandro. Os núcleos do conchal. SP Editora - Artur Nogueira, SP- 2ª̣edição, 2011.

FERREIRA, Luiz Carlos Fromber. (Org.) Cosmópolis: de fazenda Funil à cidade universo. São Paulo: Pancrom, 2011.

FILHO, Nestor Goulart Reis. Quadro da Arquitetura no Brasil. São Paulo. 9ạ edição. Editora Perspectivas. 2000.

FONSECA, Claudia Damasceno. Arraiais e vilas d'el rei: espaço e poder nas Minas setecentistas. Belo Horizonte, Editora UFMG, 2011.

FLORENCE, Hércules. Viagem fluvial do Tietê ao Amazonas de 1825 a 1829. São Paulo. Melhoramentos. (s.d.)

FONSECA, Claudia Damasceno. Arraiais e vilas d'el rei: espaço e poder nas Minas setecentistas. Belo Horizonte, Editora UFMG, 2011.

FRADE, Gabriel. Arquitetura Sagrada no Brasil. Sua evolução até as vésperas do Concilio Vaticano II.São Paulo, Edições Loyola, 2007.

GADELHA, Regina Maria D’Aquino Fonseca. Os núcleos coloniais e o processo de acumulação cafeeira (1850-1920). Contribuição ao estudo da colonização em São Paulo. São Paulo: 1982. Tese (Doutorado) - Faculdade de Filosofia, Letras e Ciências Humanas da Universidade de 
São Paulo.

GHIRARDELLO, Nilson. A formação dos patrimônios religiosos no processo de expansão urbana paulista (1850-1900). Editora Unesp (Edunesp), São Paulo, 2010.

GODOY, Manoel Pereira de. Contribuição à História Natural e Geral de Pirassununga. Volume II. Pirassununga, SP -1975.

HEMEROTECA DIGITAL. Jornal "Correio Paulistano" de 22 de setembro de 1915 (http:// bndigital.bn.br/hemeroteca-digital/. Acessado em: 19/11/2019).

HOLLANDA, Sérgio Buarque de. Raízes do Brasil. São Paulo: Companhia das Letras, 1998.

HOORNAERT, Eduardo. Formação do catolicismo brasileiro: 1550-1800 - Ensaio de interpretação a partir dos oprimidos. Petrópolis: Vozes, 1974.

IBGE. Anuário Estatístico do Brasil - 1950. (https://biblioteca.ibge.gov.br/visualizacao/ periodicos/20/aeb_1950.pdf). Acessado em: 26/11/2020.

Anuário Estatístico do Brasil - 1908 a 1912. (https://biblioteca.ibge.gov.br/ visualizacao/periodicos/20/aeb_1908_1912_v3.pdf). Acessado em: 26/11/2020.

KESSEL, Carlos. Arquitetura neocolonial no Brasil: entre o pastiche e a modernidade. Rio de Janeiro: Jauá Editora, 2008

LEMOS, Carlos Alberto Cerqueira Como nasceram as cidades brasileiras. São Paulo: Studio Nobel, 2016.

. El estilo que nunca existió. In AMARAL, Aracy (Org.). Arquitectura neocolonial: América Latina, Caribe, Estados Unidos. 1a. ed. São Paulo: Memorial Fondo de Cultura Económica, 1994, pp. 147-65. 336 p, ilp\&b.

Alvenaria Burguesa. Breve história da arquitetura residencial de tijolos em São Paulo a partir do ciclo econômico liderado pelo café. 2a Edição. São Paulo: Nobel, 1989.

LIMA JUNIOR, Augusto de. Arte Religiosa. Belo Horizonte: Instituto de História, Letras e Arte, 1966.

LIMEIRA, Câmara Municipal de. Livro de Vendas de Terras da Câmara. (1875). Limeira: Câmara Municipal

LIMEIRA. Câmara Municipal. Actas da Câmara de Limeira. (1880). Limeira, SP. Actas da Câmara de Limeira. (1880-1884). Limeira, SP.

LIMEIRA, Prefeitura Municipal de. Plano Diretor. Limeira: Prefeitura de 
LIMEIRA, Revista de. Revista de Limeira. 1926. Limeira: s.i. Fotocópia.

LANDIN, Paula da Cruz. Desenho de uma paisagem urbana: as cidades do interior paulista. São Paulo, Editora UNESP (Edunesp), 2010.

MELO, Joana. Ricardo Severo: Da Arqueologia Portuguesa à Arquitetura Brasileira. São Paulo, Anna-blume, Fapesp, 2007.

MENDONÇA, Antônio Gouveia. República e Pluralidade religiosa no Brasil. São Paulo, Revista USP, no 59. 2003. p.149.

MASCARO, Luciana Pelaes. Difusão da arquitetura neocolonial no interior paulista, 19201950. Tese de Doutorado em Teoria e História da Arquitetura e do Urbanismo - Escola de Engenharia de São Carlos, Universidade de São Paulo, São Carlos, 2008.

MAYUMI, Lia. Taipa, canela-preta e concreto. Estudo sobre o restauro de casas bandeiristas. São Paulo, Romano Guerra, 2008.

MARX, Murillo de Azevedo. Cidade no Brasil, terra de quem? Editora da Universidade de São Paulo \& Editora Nobel, São Paulo, 1991.

MATOS, Odilon Nogueira de. Café e ferrovias: a evolução ferroviária de São Paulo e o desenvolvimento da cultura cafeeira. Campinas: Pontes, 1990. SP

MATRIZ, Fábrica da. Livro do Fabriqueiro da Matriz. (1847-1857). Limeira: Fábrica da Matriz. MOTTA JUNIOR, J. P. da. Almanach de Pirassununga para 1885.

MOTTA, Márcia Maria Menendes. Direito à terra no Brasil: a gestão do conflito 1795-1824. Alameda Casa Editorial, 2a edição, São Paulo, 2012.

MOURA FILHA, Maria Berthilde. De Filipéia à Paraíba: uma cidade na estratégia de colonização do Brasil. Superintêndenciado Iphan na Paraíba, João Pessoa, 2010.

NARDI, Antônio Maria. Carta à Benedito Calixto Neto. (1962) Santuário São Sebastião, Porto Ferreira, SP. . Carta à Luzia Ribeiro de Oliveira. (1951) Santuário São Sebastião, Porto Ferreira, SP. Carta ao Padre Nestor Cavalcanti Maranhão. (1950) Santuário São Sebastião, Porto Ferreira, SP.

NETO, Benedito Calixto de Jesus. Carta à Antônio Maria Nardi. (1962) Santuário São Sebastião, Porto Ferreira, SP.

NORA, Moysés. Relatório da freguezia de Porto Ferreira. São Paulo: Typographia Andrade \& 
Mello, 1904.

NOSSA FÉ NOS CONDUZIU EM NOSSA MISSÃO. Revista comemorativa dos 75 anos da Paróquia Jesus Crucificado de Iracemápolis. Iracemápolis - setembro de 2011.

OLIVEIRA, Flávio Silva. Histórias e Estórias de Porto Ferreira. Porto Ferreira: Gráfica São Paulo, 2005.

O MUNÍCIPIO. Um histórico da Capela de Nossa Senhora da Conceição. Jornal "O Munícipio". Edição de 2 de fevereiro de 1958. №2087. Leme, SP.

PALAZZO, Pedro Paulo. Patrimonialização e exemplaridade da arquitetura religiosa: paralelos entre o renascimento e o neocolonial. In: Arquimemória 5, 2017, Salvador. O global, o nacional e o local na preservação do patrimônio. Salvador: IAB-BA: UFBA, 2017. v. 1. p. 13.

PARÓQUIA Jesus Crucificado. (JC). Livro Tombo I. Iracemápolis.

PARÓQUIA. Nossa Senhora das Dores. (NSD). Livro Tombo /l (1870-1903). Limeira . Livro Tombo III (1905 - 1914). Limeira . Livro Tombo IV (1914-1921). Limeira . Livro Tombo V (1921 - 1949). Limeira . Livro Tombo VI (1949 -). Limeira

PARÓQUIA Nossa Senhora da Conceição. (NSC). Livro Tombo I. Santa Cruz da Conceição . Livro Tombo I. Santa Cruz da Conceição. . Livro Tombo II. Santa Cruz da Conceição. . Livro Tombo III. Santa Cruz da Conceição.

PARÓQUIA Santa Cruz. (SC). Livro Tombo I (s.d.). Campinas.

PARÓQUIA Santa Gertrudes. (SG). Livro Tombo I (1909-1926). Cosmópolis. . Livro Tombo I/ (1926-1945). Cosmópolis. . Livro Tombo III (1945-atual). Cosmópolis.

PENTEADO, Mario. Carta ao Bispo Diocesano de Campinas. Cúria de Campinas, Campinas, 1952.

PETRONE, Maria Thereza Schorer. A lavoura canavieira em São Paulo - expansão e declínio. Difusão Europeia do Livro, São Paulo, 1968. 
PINHEIRO, Maria Lúcia Bressan. Neocolonial, Modernismo e Preservação do Patrimônio no Debate cultural dos Anos 1920 no Brasil. Editora da Universidade de São Paulo, Fapesp, São Paulo, 2011.

. Ricardo Severo e o Neocolonial: Tradição e Modernidade no debate cultural dos anos 1920 no Brasil.Revista Eletrônica Intellectus. UERJ, Rio de Janeiro V.10 n.1, 2011. (http:// www.e-publicacoes.uerj.br/index.php/intellectus/article/view/27692/19876. Acessado em: 30/08/2019).

Arquitetura religiosa neocolonial em São Paulo: o debate dos anos 1920 e sua repercussão. In: III Seminário Internacional Patrimônio Sacro, 2017. (no prelo)

PFROMM NETTO, Samuel. Dicionário de Piracicabanos. 1ed. São Paulo,PNA, 2013.

PUPO, Celso. Maria de Mello. Campinas, seu berço e juventude. Academia Campinense de Letras, Campinas, 1969.

REIS FILHO, Nestor Goulart. Quadro da Arquitetura no Brasil. São Paulo, Perspectiva, 1970.

ROCHA, Alexandre Luís. A Igreja da Boa Morte e a taipa de pilão. Revista Enfoque, abril de 1988, $\mathrm{p}-5$.

RODRIGUES, José Watsh. Documentário Arquitetônico. São Paulo,EDUSP, 1979.

ROSADA, Mateus. Sob o signo da cruz: Igreja, Estado e secularização (Campinas e Limeira 1774 - 1939). Dissertação de Mestrado em Arquitetura e Urbanismo, Escola de Engenharia de São Carlos, Universidade de São Paulo, São Carlos, 2010.

Mateus. Igrejas paulistas da colônia e do império - arquitetura e ornamentação. Tese de Doutorado, Instituto de Arquitetura e Urbanismo, Universidade de São Paulo, São Carlos, 2016.

Mateus. A taipa, o templo o tempo: A Igreja da Boa Morte de Limeira. (https:// www.academia.edu/7587802/A_Taipa_o_Tempo_o_Templo_A_Igreja_da_Boa_Morte_de_ Limeira_SP. Acessado em: 03/09/2019).

O plano sem traçado: a Igreja na lógica urbanística portuguesa de criação das vilas coloniais. In: PEIXOTO, Elane Ribeiro; DERNTL, Maria Fernanda; PALAZZO, Pedro Paulo; TREVISAN, Ricardo (Orgs.) Tempos e escalas da cidade e do urbanismo: Anais do XIII Seminário de História da Cidade e do Urbanismo. Brasília, DF: UNB, 2014 (http://www. shcu2014.com.br/content/plano-tracado-igreja-na-logica-urbanistica-portuguesa-criacaodas-vilas-coloniais. Acessado em: 20/11/2020).

RUSKIN, John. A lâmpada da memória. Cotia, Ateliê Editorial, 2008.

SABARIM, Fernanda. Capitalistas em Campinas: 1873-1884. Monografia de conclusão do Curso de Ciências Econômicas. Faculdade de Economia - Universidade Estadual de Campinas 
(UNICAMP). Campinas, 2010.

SANTOS, Paulo Ferreira dos. Formação de cidades no Brasil Colonial. Rio de Janeiro: Editora UFRJ, 2001.

SANTOS NETO, José Moraes dos. Nova Odessa - 100 anos da terra fértil, os frutos do progresso. Campinas, Editora Komedi, 2006.

SANTUÁRIO. São Sebastião. (SS). Livro Tombo. (1965-atual). Porto Ferreira.

SEADE, Fundação. Mapas divisão político-administrativo. 500 anos. (http://produtos.seade. gov.br/produtos/500anos/index.php?tip=mapa. Acessado em: 12/12/2020)

SILVA, Danuzio Gil Bernardino da. Usina Ester: 100 anos de história. 1898-1998. Cosmópolis: Aluminis, 1998.

SILVA, Wellington Teodoro da. Catolicismo militante na primeira metade do século XX brasileiro. História Revista. UFG. 2009.

SILVEIRA, Marcus Marciano Gonçalves da. Templos modernos, templos ao chão: a trajetória da arquitetura religiosa modernista e a demolição de antigos templos católicos no Brasil. Belo Horizonte. Autêntica Editora, 2011.

SIMÕES, Manoel. Provisão para a construção de uma capela. (1943). Cúria Metropolitana de Campinas, Campinas, SP.

SEGAWA, Hugo. Arquiteturas no Brasil 1900-1990. São Paulo, Edusp, 1997.

SOUSA. Pe. Bento de. Arte Religiosa. Revista Eclesiástica Brasileira. Rio de Janeiro, v.10, n.3, p.650-5, set-1950.

SOUZA, Ney (Org.). Catolicismo em São Paulo: 450 anos da presença da Igreja Católica em São Paulo (15545-2004). São Paulo, Paulinas, 2004.

TEIXEIRA, João. Porto Ferreira: sua história, seus costumes, suas tradições e sua gente. Porto Ferreira: Gráfica Máximo Fenili, 2009.

TIRAPELLI, Percival. (org) Arte sacra colonial: Barroco Memória Viva. 2 ed. São Paulo: FAPESP, Imprensa Oficial, Edunesp, 2005.

TREFT, Renan Alex; SALGADO, Ivone. Construção da Igreja Matriz Nossa Senhora das Dores e da Capela Nossa Senhora da Boa Morte de Limeira. In: Norma Regina Truppel Constantino; Renata Cardoso Magagnin; Sandra Medina Benini. (Org.). Cidade, História e Patrimônio. 1ed. TUPA: ANAP, 2019, v. único, p. 143-162. 
Configuração Espacial de Limeira: Capela (1826), Freguesia (1832) e Vila (1844). Texto analítico de Iniciação Cientifica. Faculdade de Arquitetura e Urbanismo. Pontifícia Universidade Católica de Campinas, Campinas, 2016.

Formação urbana no entorno das Igrejas Nossas Senhora das Dores e Nossa Senhora da Boa Morte e Assumpção de Limeira. Texto analítico de Iniciação Cientifica. Faculdade de Arquitetura e Urbanismo. Pontifícia Universidade Católica de Campinas, Campinas, 2017.

TSCHUDI, Johann Jakob von. Viagem as províncias do Rio de Janeiro e São Paulo. São Paulo, Martins, 1953.

VALE, Marília Maria. Arquitetura religiosa do século XIX no antigo sertão da farinha podre. Tese (Doutorado). Faculdade de Arquitetura e Urbanismo. Universidade de São Paulo. São Paulo, 1998.

ZANARDO, José. Iracemápolis - fatos e retratos. Iracemápolis. Porto de Idéias, 2008.

ZAKIA, Silvia Amaral Palazzi. Mario Penteado: Arquiteto e Obra. Dissertação de Mestrado em Arquitetura e Urbanismo, Programa de Pós-Graduação em Urbanismo, Pontifícia Universidade Católica de Campinas, Campinas, 2004.

Construção, Arquitetura configuração Urbana de Campinas nas décadas de 1930 e 1940. O papel de quatro engenheiros modernos. Tese de Doutorado. FAU USP. São Paulo 2012. 

ANEXOS 


\section{ANEXOS}

\section{DADOS BIOGRÁFICOS}

PROFISSIONAIS QUE ATUARAM NOS PROJETOS APRESENTADOS

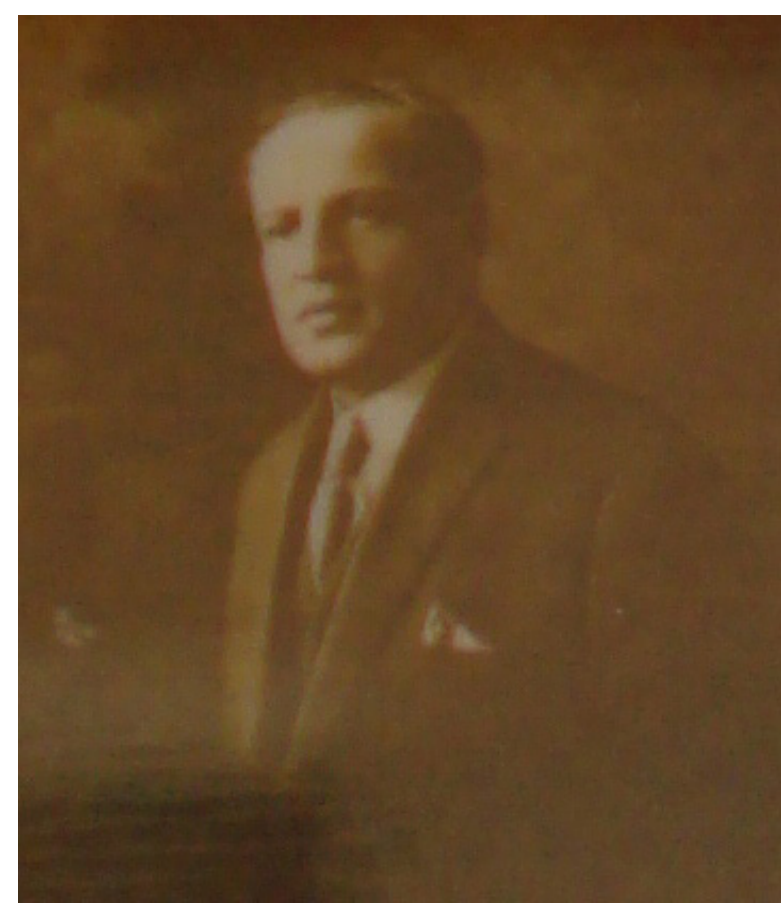

Figura A1: Retrato de Agostinho Balmes Odísio Fonte: ROSADA, 2010.

\section{AGOSTINHO BALMES ODISIO}

(Turim (Itália) 1881 - Fortaleza (Brasil) 1948)

Agostinho Odisio ganhou ainda jovem um concurso para esculpir o busto de Vittotino Emanuelle no Palazio Venezia, em Roma, o que the garantiu um bolsa de estudos na Universidade de Belas Artes em Paris, onde pode estudar com o mestre Auguste Rodin. Realizou algumas obras em Turin, como o Mausoléu das Relíquias de São João Bosco e esculturas da Igreja de São Genésio. No Brasil, além do projeto para a Matriz de Limeira, realizou projetos em diversas cidades paulistas, como: Franca, Jundiaí, Ribeirão Preto, Pindamonhangaba, São Paulo e Taubaté e nas mineiras: Itajubá, Juiz de Fora, Ouro Fino, Pouso Alegre, Santa Rita do Sapucaí, Santos Dumont e Três Corações, além da cidade do Rio de Janeiro. Na região realizou o projeto da Igreja de Nossa Senhora do Carmo, em Campinas, atual Basílica do Carmo. Mudando-se para o Ceará realizou inúmeras obras em diversas cidades, na sua maioria em estilo Art Déco, abandonando o estilo neogótico e neoclássico realizadas em grande parte de suas obras. 


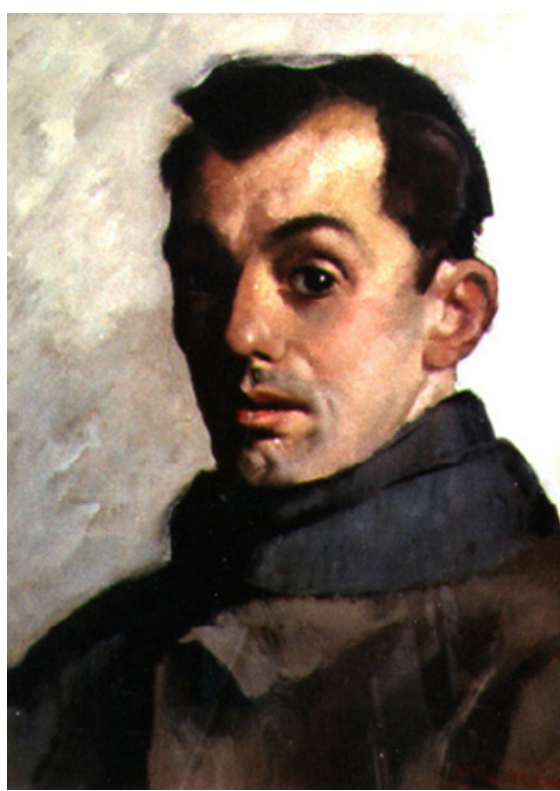

Figura A2: Autoretrato do pintor Antônio Maria Nardi. Fonte: Itaú Cultural.

\section{ANTÔNIO MARIA NARDI}

(Ostellato (Itália) 1897 - Bolonha (Itália) 1973).

Artista plástico formado na Itália, onde estudou a pintura sacra e a composição de afrescos para igrejas. Chegou ao Brasil em 1949 para realizar uma exposição no Ministério da Educação, e acabou se estabelecendo em Niterói. Foi autor de diversos tipos de gravuras, telas, vitrais, esculturas e principalmente pinturas murais. Sua arte expressionista decora inúmeros altares e capelas do Brasil. Destaca-se entre seus trabalhos os mosaicos da Igreja Nossa Senhora do Rosário de Serra Negra e o monumento à Anchieta da Praça da Sé, construído em 1954 nas comemorações do IV Centenário.

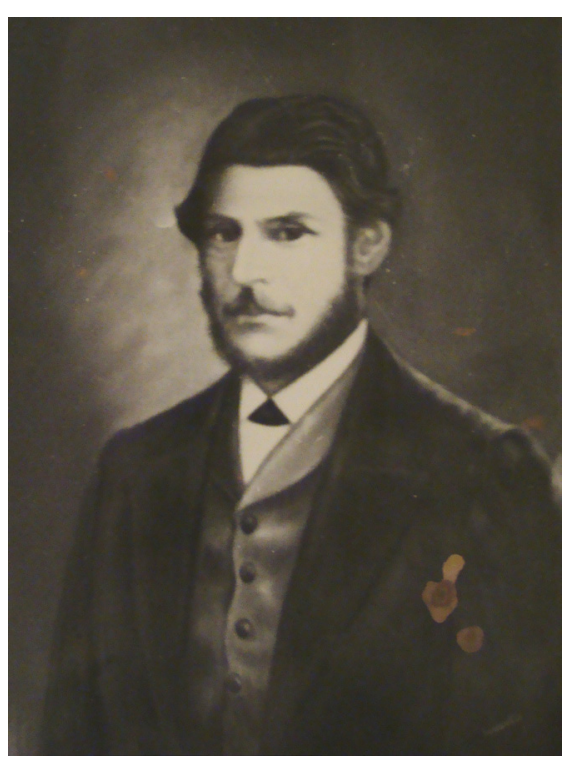

Figura A3: Retrato do arquiteto Aurélio Civatti. Fonte: Acervo do Museu Histórico e Pedagógico Major José Levy Sobrinho.

\section{AURÉLIO CIVATTI}

(Florença (Itália) 1837 - Itápolis (Brasil) 1917)

Importante arquiteto e entalhador, Civatti realizou inúmeras obras na região, dentre elas a Igreja da Boa Morte em Limeira, única obra sua que não foi demolida. Construiu também uma versão do templo da Matriz de Limeira, a Matriz da cidade de São Carlos e financiou a construção de uma capela em honra a São Sebastião na mesma cidade. Casou-se com a neta do Barão de Campinas e tornou-se importante cafeicultor na região de São Carlos. No fim da vida, foi eleito vereador na cidade de Itápolis. 


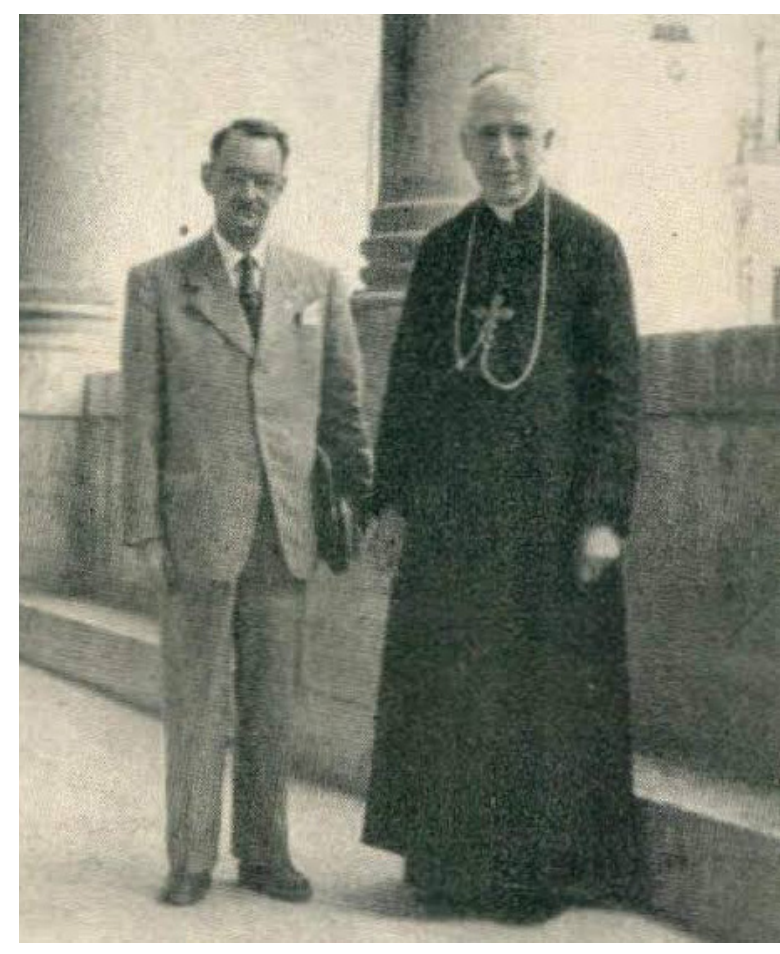

Figura A4: Benedito Calixto com o Monsenhor Constanti - Presidente da Comissão Pontifícia de Arte Sacra em Roma em 1949. Fonte: Santuário de Aparecida.

\section{BENEDITO CALIXTO DE JESUS NETO}

(Bebedouro (Brasil) 1906 - Aparecida (Brasil) 1972)

Arquiteto e Urbanista formado pelo Centro Universitário BelasArtes deSão Paulo, foiautor de inúmeros projetos de igrejas pelo Brasil. Sua produção, dedicada exclusivamente aos edifícios religiosos, possui exemplares de todos os portes e estilos. Seu maior projeto é a Basílica Nacional de Aparecida, projetada em neorromânico basilical. Dedicou sua carreira ao estudo das formas e do espaço sagrado, o que fez com que fosse nomeado assessor técnico da Comissão de Arte Sacra da Arquidiocese de São Paulo, onde elaborou pareceres e laudos referentes a construção e reformas de igrejas no estado de São Paulo. Benedito Calixto é neto do pintor Benedito Calixto de Jesus.

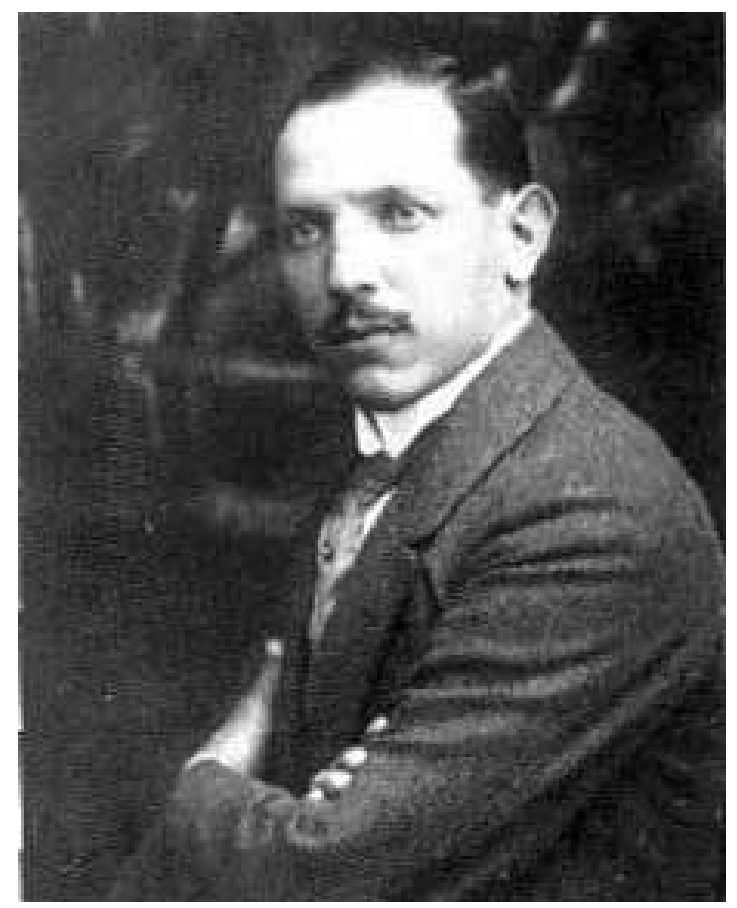

\section{FELISBERTO RANZINI}

(Lombárdia (Itália) 1881 - São Paulo (Brasil) 1976).

Artista plástico e arquiteto radicado no Brasil, onde estudou no Liceu de Artes e Ofícios. Foi professor da Escola Politécnica e funcionário do Escritório Técnico Ramos de Azevedo, no qual participou do desenvolvimento de inúmeros projetos, dentre eles o Mercado Municipal, Palácio da Justiça e a neocolonial Faculdade de Direito da USP. Sua produção no campo das artes visuais foi predominantemente composta por pinturas de paisagens.

Figura A5: Retrato de Felisberto Ranzini. Fonte: Wikipéida. 


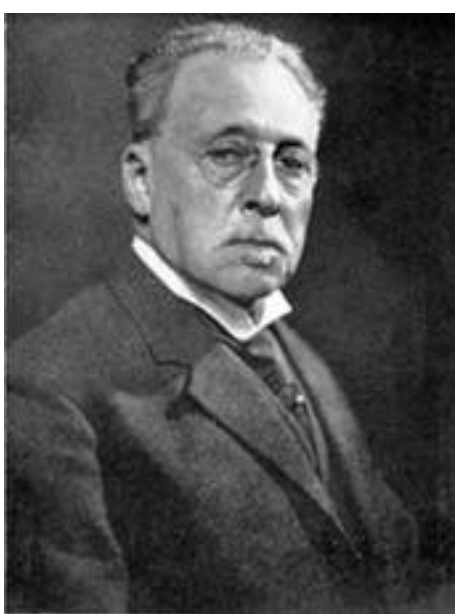

Figura A6: Retrato do arquiteto Ramos de Azevedo. Fonte: Wikipédia.

\section{FRANCISCO DE PAULA RAMOS DE AZEVEDO}

(Campinas (Brasil) 1851 - São Paulo (Brasil) 1928)

Com dupla formação, Engenheiro - Arquiteto, Ramos de Azevedo é um dos maiores nomes da arquitetura eclética do Estado de São Paulo. É o responsável por grandes obras na cidade de São Paulo, onde instalou seu escritório técnico. Produziu grande parte das residências da elite paulista, além de um grande número de edifícios públicos. Participou ainda da fundação da Escola Politécnica da USP e foi o diretor do Liceu de Artes e Oficio de São Paulo. Dentre suas obras, destaca-se o Teatro Municipal de São Paulo, o Mercado Municipal e a Catedral Metropolitana de Campinas.

\section{JOAQUIM BEZERRA DA SILVA}

(desconhecido)

Com dupla formação, foi funcionário da Secretaria de Agricultura e responsável por inúmeros projetos de escolas agrícolas no estado de São Paulo. No que se refere a arquitetura religiosa, além da Igreja Jesus Crucificado, projetou o Seminário Santo Antônio de Agudos. Foi o responsável pela elaboração do traçado urbano da cidade de Fernão - SP e professor da

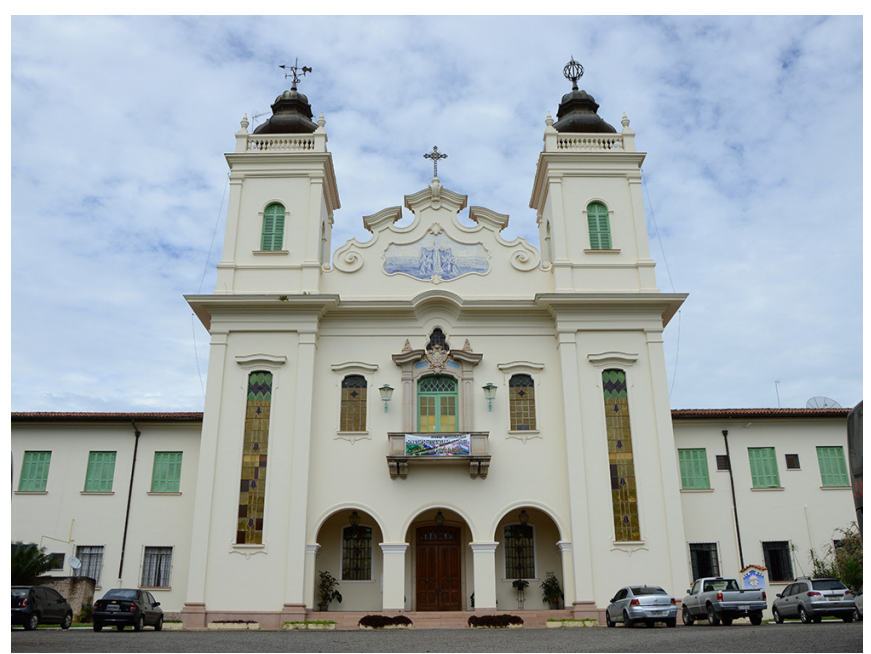

Figura A7: Seminário Santo Antônio em Agudos, projetado da por Joaquim Bezerra da Silva em 1950. Fonte: Seminário Santo Antônio de Agudos. Faculdade de Arquitetura e Urbanismo da USP de 1950 a 1970.

\section{LUIZ LEONARDI}

(Toscana (Itália) 1879 - Araras (Brasil) 1956).

Marmorista italiano radicado no Brasil e proprietário de uma marmoraria na cidade de Araras. Sua empresa possuía filiais nas cidades de Piracicaba e Lençóis Paulistas, e seus trabalhos foram executados em boa parte das cidades da região. Além de túmulos e jazigos, o artista realizou altares em inúmeras capelas e igrejas, entre elas a primeira capela de Iracemápolis. 
Leonardi é o também o autor de um dos projetos do altar de São Sebastião da nova matriz de Porto Ferreira, que não foi executado.

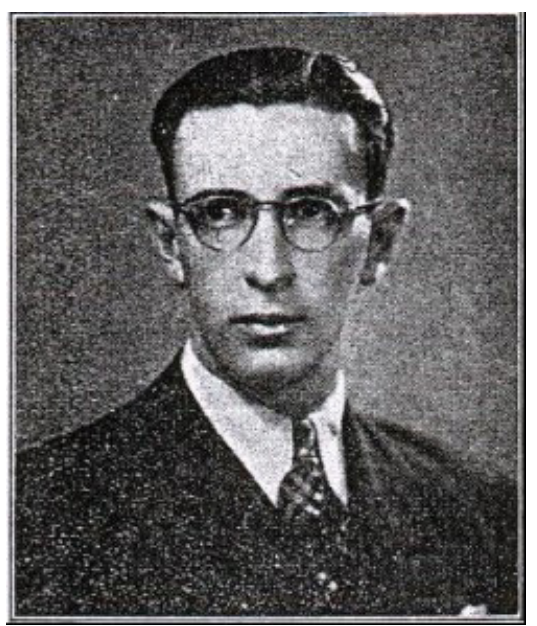

Figura A8: Mário de Camargo Penteado Fonte: ZÁKIA, 2004.

\section{MÁRIO DE CAMARGO PENTEADO}

(Campinas (Brasil) 1905 - 1984)

Possuía dupla formação (engenheiro-arquiteto) pela ENBA (Escola Nacional de Belas Artes), quando Lúcio Costa era o diretor. Após se formar em 1931, fixou escritório em 1934 na cidade de Campinas, onde realizou diversas obras do segmento Moderno, Art Decó e especialmente Neocolonial. Construiu inúmeras residências para a elite no bairro Cambuí e inúmeros edifícios públicos na região. Mario Penteado é autor da primeira casa considerada modernista de Campinas e foi membro da Comissão de melhoramentos urbanos instituída em 1936, além disso, foi vereador eleito da cidade de Campinas.

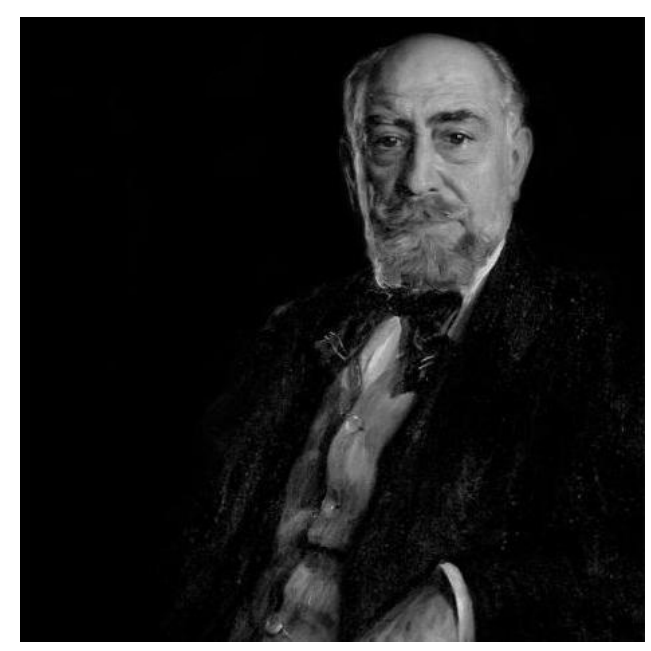

Figura A9: Retrato de Ricardo Severo. Fonte: Wikipédia.

RICARDO SEVERO DA FONSECA E COSTA

(Lisboa (Portugal) 1896 - São Paulo (Brasil)1940)

Engenheiro-arquiteto radicado no Brasil após envolvimentos em revoluções contra a monarquia portuguesa. Severo atuava na área da arqueologia e era ainda escritor. Na sua chegada ao Brasil, vinculouse ao escritório técnico de Ramos de Azevedo, onde realizou inúmeros projetos. É considerado o mentor do movimento Neocolonial, cujos ideais se alastraram na primeira metade do século XX, reverberando diretamente nos projetos e novas construções. Ricardo Severo fundou ainda o escritório Severo Villares, onde realizou grandes projetos em neocolonial, como a Faculdade de Direito do Largo São Francisco e o Hospital da Beneficência Portuguesa. 


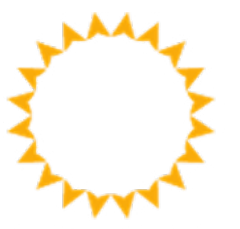

FAUUSP

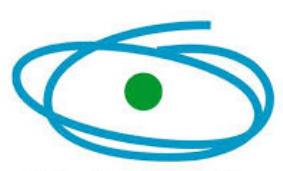

C A P E S 